\title{
Tetrahydroxydiboron-Mediated Palladium-Catalyzed Transfer Hydrogenation and Deuteriation of Alkenes and Alkynes Using Water as the Stoichiometric H or D Atom Donor
}

Steven P. Cummings, Thanh-Ngoc Le, Gilberto E. Fernandez, Lorenzo G. Quiambao, and Benjamin J. Stokes* School of Natural Sciences, University of California, Merced, 5200 N. Lake Road, Merced, CA 95343, USA

\section{Table of Contents}

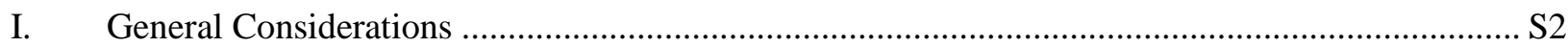

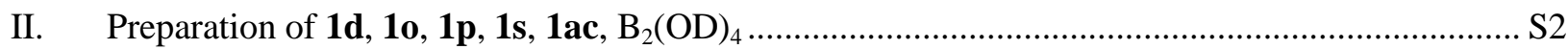

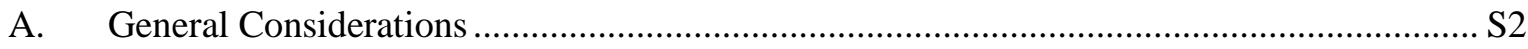

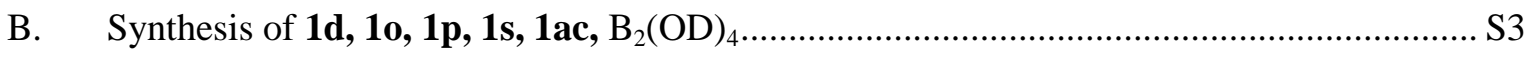

III. Palladium Catalyzed Transfer Hydrogenation..................................................................... S5

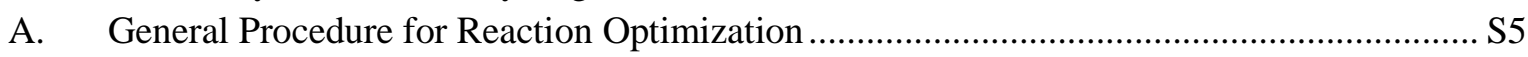

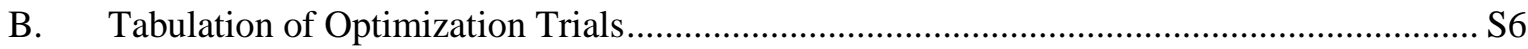

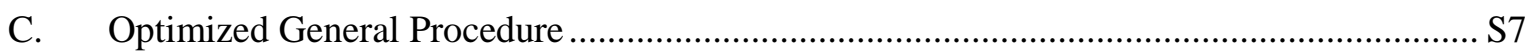

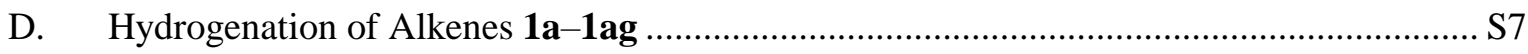

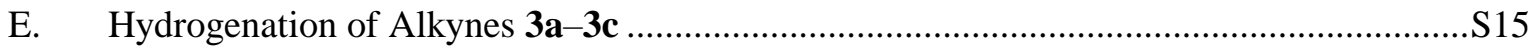

F. Attempted Deboronation of Phenethylboronic Acid .....................................................S16

IV. Palladium Catalyzed Transfer Deuteriation Reactions.............................................................S17

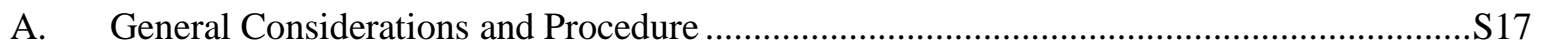

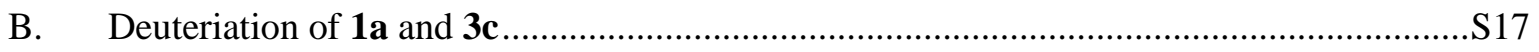

C. Kinetic Isotope Effect; Crossover Experiment; Stereoselectivity of Pd Insertion ...............S18

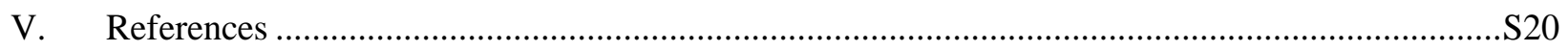

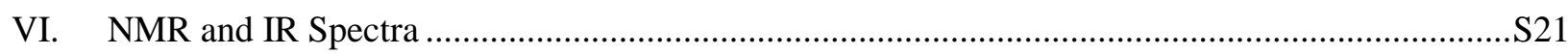

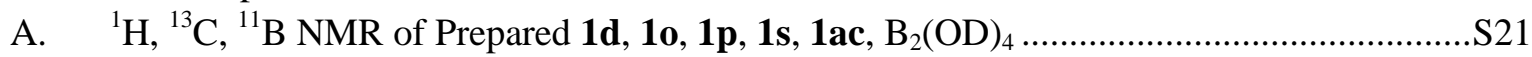

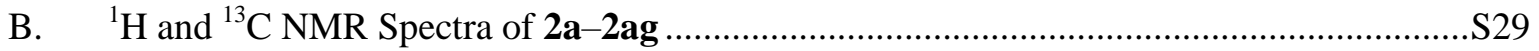

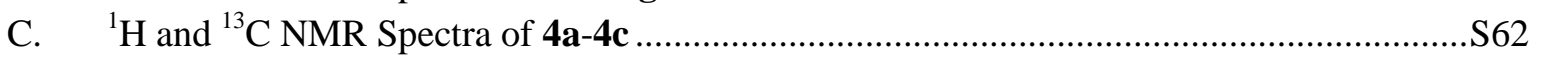

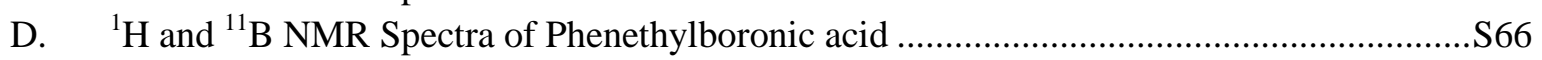

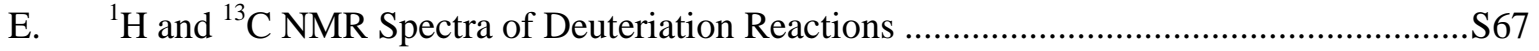

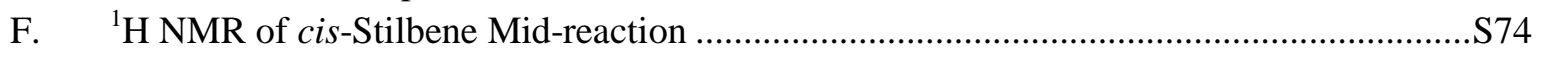




\section{General Considerations}

Solvents were obtained from either Sigma-Aldrich or Fisher Scientific and passed through an alumina column (Innovative Technologies), unless anhydrous. Water content of solvents were determined by KarlFisher titration to be less than $20 \mathrm{ppm}$. $\mathrm{H}_{2} \mathrm{O}$ was obtained from a Barnstead water purification system followed by three freeze-pump-thaw cycles. Sources of $\mathrm{B}_{2}(\mathrm{OH})_{4}$ included AK Scientific, Strem Chemical, and Boron Molecular. Benzyl bromide, 1-octene, 2,5-dihydrofuran, 1,3,5-trimethoxybenzene, cyclopentene, diphenylacetylene, phenylacetylene, ethyl vinylketone, and styrene were purchased from Acros Organics. Bis(catecholato) diboron and bis(pinicolato) diboron were purchased from AK Scientific. Cis-stilbene, 1,1-diphenylethylene, $\alpha$-methyl stilbene, and catecholborane were purchased from Alfa Aesar. Hexachlorodisilane was purchased from Gelest. 4-Chlorostyrene was purchased from Matrix Scientific. Cinnamyl alcohol, ethyl cinnamate, trans-stilbene, diethyl allylmalonate, 1-phenylpropyne, 1pentene, 1-chloro-1-cyclopentne, $\alpha$-acetomidocinnamic acid, and pinacolborane were purchased from Sigma-Aldrich. 1-bromo-1-cyclohexene was purchased from CombiBlocks. Diethyl 2-propynylmalonate was purchased from TCI America. Palladium on carbon was obtained from Sigma-Aldrich (unreduced, 5 wt. \% or 10 wt. \%) and Strem (reduced, 5 wt. \%). Pd(dba) $)_{2}$ was purchased from Acros Organics. Palladium on Carbon, 0.6\% NanoSelect LF 100, was purchased from STREM Chemicals. Lindlar's catalyst was purchased from Sigma-Aldrich. $\mathrm{Pd}(\mathrm{OAc})_{2}$, and $\mathrm{Pd}\left(\mathrm{PPh}_{3}\right)_{2} \mathrm{Cl}_{2}$ were purchased from Oakwood Chemicals. All compounds were used as received with the exception of tetrahydroxydiboron, which was washed with acetone and hexanes prior to drying overnight under vacuum. All materials were massed out using a MettlerToledo XS105 balance repeatable to $0.1 \mathrm{mg}$. NMR spectra were obtained on Agilent spectrometers, with ${ }^{1} \mathrm{H}$ NMR spectra obtained at $500 \mathrm{MHz}$ or $400 \mathrm{MHz}$ and referenced to the residual $\mathrm{CHCl}_{3}$ singlet at $7.26 \mathrm{ppm}$, or $\mathrm{CH}_{2} \mathrm{Cl}_{2}$ at $5.32 \mathrm{ppm}$, or $\mathrm{CH}_{3} \mathrm{CN}$ at $2.13 \mathrm{ppm} .{ }^{13} \mathrm{C} \mathrm{NMR}$ spectra were obtained at $125 \mathrm{MHz}$ or $100 \mathrm{MHz}$ and referenced to the center line of the residual $\mathrm{CHCl}_{3}$ triplet at 77.16 ppm, or the $\mathrm{CH}_{2} \mathrm{Cl}_{2}$ quintet at $54.00 \mathrm{ppm}$, or the $\mathrm{CH}_{3} \mathrm{CN}$ singlet at $182.26 \mathrm{ppm}$. ${ }^{11} \mathrm{~B}$ NMR spectra were obtained at $160 \mathrm{MHz}$ in either $\mathrm{CH}_{2} \mathrm{Cl}_{2}, \mathrm{MeCN}$, or DMSO and referenced to $\mathrm{B}(\mathrm{OH})_{3}$ singlet set at 19.8 ppm. The abbreviations $\mathrm{s}, \mathrm{d}, \mathrm{t}, \mathrm{q}, \mathrm{dd}$, dt, and $\mathrm{m}$ stand for the resonance multiplicities singlet, doublet, triplet, quartet, doublet of doublets, doublet of triplets, and multiplet, respectively. GC analysis was obtained on a Thermo Trace 1300 with a $30 \mathrm{~m} \mathrm{X} 0.25 \mathrm{~mm} \mathrm{X} 0.25 \mu \mathrm{m}$ column. FT-IR analysis was obtained on a Thermo-Nicolet 380 using a diamond GladiATR from Pike technologies; the abbreviations $\mathrm{w}, \mathrm{m}$, and $\mathrm{s}$ for the characteristic peaks stand for relative intensities of weak, medium, and strong, respectively, as determined by $0-25 \%, 25-50 \%$ and greater than $50 \%$ absorbance

\section{Preparation of 1d, 1o, 1p, 1s, 1ac, $\mathrm{B}_{2}(\mathrm{OD})_{4}$}

\section{A. General Considerations:}

All Schlenk manipulations were carried out under an argon atmosphere. Compounds were used as received, unless stated otherwise. From STREM, 4-aminostyrene, was 95\% pure with balance 4ethylaniline. Deuterium oxide $\left(99.9 \%\right.$ D), 35\% Deuterium chloride in $\mathrm{D}_{2} \mathrm{O}(99 \%$ D) were obtained through Sigma Aldrich. Sodium nitrite and sodium azide were purchased through Acros Organics. 


\section{B. Synthesis of $1 \mathrm{~d}, 1 \mathrm{p}, 1 \mathrm{p}, 1 \mathrm{~s}, 1 \mathrm{ac}, \mathrm{B}_{2}(\mathrm{OD})_{4}$ :}

$$
\mathrm{HO}+\sqrt{\overline{3}}+\mathrm{Ph} \smile \mathrm{Br} \frac{\mathrm{NaH}}{\mathrm{THF}, 0^{\circ} \mathrm{C}} \operatorname{BnO}+\underset{\mathbf{1 d}}{=}
$$

1-Benzyloxypent-4-ene 1d. Using a modified literature procedure, ${ }^{1} 128 \mathrm{mg}$ of sodium hydride (3.1 mmol) was added to a Schlenk flash and washed twice with hexanes. Under argon, $10 \mathrm{~mL}$ of dry tetrahydrofuran was added and cooled to $0{ }^{\circ} \mathrm{C}$. Subsequently, $330 \mu \mathrm{L}(2.92 \mathrm{mmol})$ of 4-penten-1-ol was added and allowed to stir for 10 minutes, followed by dropwise addition of $500 \mathrm{mg}$ ( $2.92 \mathrm{mmol})$ of benzyl bromide. The reaction was stirred while warming to room temperature for 1 hour. Methanol was slowly added to quench excess sodium hydride, and the product was extracted with hexanes, and the extract was dried over sodium sulfate. Solvent removal resulted in $315 \mathrm{mg}$ of a colorless oil $(62 \%, \rho=0.928 \mathrm{~g} / \mathrm{mL})$. Spectral data was consistent with that of Gresser and co-workers. ${ }^{1}{ }^{1} \mathrm{H}$ NMR $\left(400 \mathrm{MHz}, \mathrm{CD}_{2} \mathrm{Cl}_{2}\right): \delta 7.49-$ $7.19(\mathrm{~m}, 5 \mathrm{H}), 5.95-5.74(\mathrm{~m}, 1 \mathrm{H}), 6.67(\mathrm{dd}, J=26.2,14.3 \mathrm{~Hz} ; 2 \mathrm{H}), 4.53(\mathrm{~s}, 2 \mathrm{H}), 3.51(\mathrm{t}, J=6.5 \mathrm{~Hz}, 2 \mathrm{H})$, 2.24-2.12 (m, 2H), 1.81-1.68 (m, 2H); $\left.{ }^{13} \mathrm{C} \mathrm{NMR} \mathrm{(100} \mathrm{MHz,} \mathrm{CD}_{2} \mathrm{Cl}_{2}\right): \delta$ 138.6, 138.3, 128.3, 127.6, $127.5,114.7,72.9,69.7,30.4,29.0$.

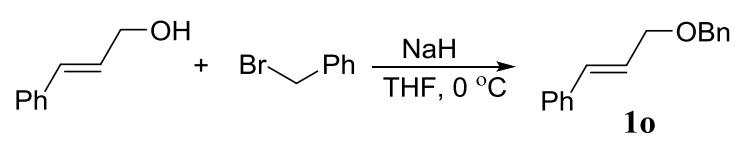

Benzyl cinnamyl ether 1o. Using a modified literature procedure, ${ }^{2} 630 \mathrm{mg}$ of sodium hydride (13.6 $\mathrm{mmol}$ ) was added to a Schlenk flask. Under argon, $10 \mathrm{~mL}$ of dry tetrahydrofuran was added and cooled to $0{ }^{\circ} \mathrm{C}$. Subsequently, $1.829 \mathrm{~g}(0.0136 \mathrm{~mol})$ of cinnamic acid was added and allowed to stir 10 minutes followed by the dropwise addition of $2.33 \mathrm{~g}(1.68 \mathrm{~mL}, 0.0136 \mathrm{~mol})$ benzyl bromide. The reaction was stirred at room temperature overnight. Methanol was slowly added to quench to excess sodium hydride, and the product extracted by ethyl acetate, and the extract dried over sodium sulfate. Solvent removal resulted in $2.53 \mathrm{~g}$ of a colorless oil $(83 \%, \rho=1.061 \mathrm{~g} / \mathrm{mL})$. Spectral data was consistent with that of Kurita and co-workers. ${ }^{2}{ }^{1} \mathrm{H}$ NMR $\left(400 \mathrm{MHz}, \mathrm{CD}_{2} \mathrm{Cl}_{2}\right): \delta 7.45-7.20(\mathrm{~m}, 10 \mathrm{H}), 6.64(\mathrm{~d}, J=15.9 \mathrm{~Hz}, 1 \mathrm{H})$, $6.34(\mathrm{dt}, J=15.9,6.0 \mathrm{~Hz}, 1 \mathrm{H}), 4.58(\mathrm{~s}, 2 \mathrm{H}), 4.21(\mathrm{dd}, J=6.0,1.4 \mathrm{~Hz}, 2 \mathrm{H}) ;{ }^{13} \mathrm{C}$ NMR $\left(100 \mathrm{MHz}, \mathrm{CD}_{2} \mathrm{Cl}_{2}\right)$ : $\delta 138.3,136.7,132.5,128.5,128.4,127.8,127.7,127.6,126.5,126.1,72.2,70.8$.

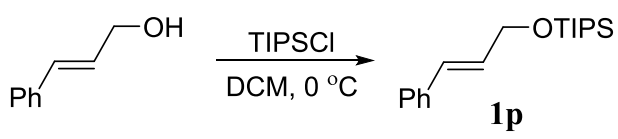

1-Triisopropylsiloxy cinnamate 1p. Using a modified literature procedure, ${ }^{3}$ a Schlenk flask containing $10 \mathrm{~mL}$ of DCM, $1.36 \mathrm{~g}$ of imidazole ( $0.0239 \mathrm{~mol}, 1.2$ equiv) and $2.60 \mathrm{~g}$ of cinnamyl alcohol (0.0194 mol) was cooled to $0{ }^{\circ} \mathrm{C}$. Slowly, $4.35 \mathrm{~mL}$ of triisopropyl chloride $(0.0203 \mathrm{mmol}, 1.05$ equiv) was added and the flask allowed to stir at room temperature until complete as monitored by TLC (1:4 EtOAc:hexanes). On completion water was added and the organics extracted with diethyl ether three times. The combined organic layers were dried over $\mathrm{MgSO}_{4}$ and solvent removed. The material was filtered through a silica frit using 1:10 DCM:hexanes and solvent removed in vacuo to yield $5.28 \mathrm{~g}$ of a colorless oil $(94 \%, \rho=0.933$ $\mathrm{g} / \mathrm{mL}$ ) consistent with reported data. ${ }^{3,4} \mathrm{H}$ NMR $\left(400 \mathrm{MHz}, \mathrm{CD}_{2} \mathrm{Cl}_{2}\right): \delta 7.39(\mathrm{~d}, J=7.2 \mathrm{~Hz}, 2 \mathrm{H}), 7.32(\mathrm{t}, J$ $=7.6 \mathrm{~Hz}, 2 \mathrm{H}), 7.25-7.19(\mathrm{~m}, 1 \mathrm{H}), 6.66(\mathrm{~d}, J=15.8 \mathrm{~Hz}, 1 \mathrm{H}), 6.31(\mathrm{dt}, J=15.8,4.8 \mathrm{~Hz}, 1 \mathrm{H}), 4.45(\mathrm{dd}, J=$ $4.8,1.8 \mathrm{~Hz}, 2 \mathrm{H}), 1.20-1.14(\mathrm{~m}, 3 \mathrm{H}), 1.12(\mathrm{~d}, J=5.6 \mathrm{~Hz}, 18 \mathrm{H}) ;{ }^{13} \mathrm{C} \mathrm{NMR}\left(100 \mathrm{MHz}, \mathrm{CD}_{2} \mathrm{Cl}_{2}\right): \delta 137.2$, $129.3,129.0,128.5,127.2,126.4,63.9,18.0,12.1$. 


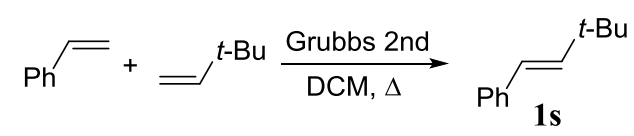

(E)-(3,3-dimethylbut-1-en-1-yl)benzene 1s. A Schlenk flask was charged with $25 \mathrm{mg}$ of Grubbs 2nd generation catalyst and degassed. To the Schlenk flask, $5 \mathrm{~mL}$ of DCM, $2.0 \mathrm{~mL}$ of styrene $(17 \mathrm{mmol})$ and $2.2 \mathrm{~mL}$ of 3,3-dimethylbut-1-ene $(17 \mathrm{mmol})$ were added. The reaction was stirred under argon in an oil bath heated to $30{ }^{\circ} \mathrm{C}$. The consumption of starting materials was monitored using solvent suppression ${ }^{1} \mathrm{H}$ NMR. Upon completion, all solvents were removed in vacuo. The remaining solid was dissolved in pentane and gravity filtered through a silica plug to remove the catalyst. The product was then collected by vacuum distillation to yield $83 \mathrm{mg}$ of a colorless oil (3\% yield). Spectral data are in agreement with Andrews and co-workers. ${ }^{5}{ }^{1} \mathrm{H}$ NMR $\left(400 \mathrm{MHz}, \mathrm{CD}_{2} \mathrm{Cl}_{2}\right)$ : $\delta 7.39-7.36(\mathrm{~m}, 2 \mathrm{H}), 7.32-7.27(\mathrm{~m}, 2 \mathrm{H}), 7.22-$ $7.17(\mathrm{~m}, 1 \mathrm{H}), 6.32(\mathrm{~d}, J=16.2 \mathrm{~Hz}, 1 \mathrm{H}), 6.26(\mathrm{~d}, J=16.2 \mathrm{~Hz}, 1 \mathrm{H}), 1.14(\mathrm{~s}, 9 \mathrm{H}) ;{ }^{13} \mathrm{C} \mathrm{NMR}(100 \mathrm{MHz}$, $\left.\mathrm{CD}_{2} \mathrm{Cl}_{2}\right): \delta 142.0,138.2,128.6,126.9,126.1,124.7,33.5,29.7$.

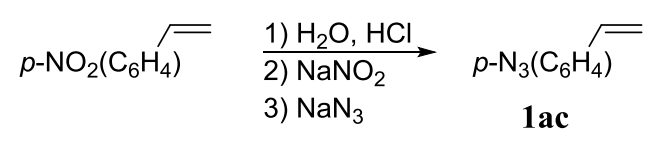

4-Azidostyrene 1ac. To a $100 \mathrm{~mL}$ three-neck round bottom flask, $15 \mathrm{~mL}$ of distilled water was bubbled with argon for 10 minutes. To the flask, $768 \mathrm{mg}(6.44 \mathrm{mmol})$ of 4-aminostyrene was added and cooled to $0{ }^{\circ} \mathrm{C}$. By adding $\mathrm{HCl}(11.3 \mathrm{M})$ drop-wise, complete dissolution of 4-aminostyrene into water was achieved, giving a yellow solution. A saturated aqueous solution of $468 \mathrm{mg}$ sodium nitrite $(6.78 \mathrm{mmol}$, 1.05 eq.) was added to the reaction, resulting in a green solution which was allowed to stir for 10 minutes. Subsequently, $480 \mathrm{mg}$ of sodium azide ( $7.38 \mathrm{mmol}, 1.15$ eq.) dissolved in minimal water was slowly added to give a yellow-brown solution, and resulting in substantial precipitate and off-gassing. After stirring for one hour, the product was extracted via diethyl ether and washed with sodium bicarbonate. The diethyl ether was removed and the resulting solid was dissolved in 1:3 benzene:hexanes and vacuum filtered through a silica pad. Removal of solvent yielded $405 \mathrm{mg}(43 \%, \rho=1.08 \mathrm{~g} / \mathrm{mL})$ of a bright orange oil that is 95\% 4-azidostyrene and 5\% 1-azido-4-ethylbenzene based on ${ }^{1} \mathrm{H}$ NMR. This material was used without purification. ${ }^{1} \mathrm{H}$ NMR $\left(400 \mathrm{MHz}, \mathrm{CD}_{2} \mathrm{Cl}_{2}\right): \delta 7.39(\mathrm{~d}, J=8.5 \mathrm{~Hz}, 2 \mathrm{H}), 6.98(\mathrm{~d}, J=8.5 \mathrm{~Hz}, 2 \mathrm{H})$, $6.67(\mathrm{dd}, J=17.6,10.9 \mathrm{~Hz}, 1 \mathrm{H}), 5.70(\mathrm{~d}, J=17.6 \mathrm{~Hz}, 1 \mathrm{H}), 5.23(\mathrm{~d}, J=10.9 \mathrm{~Hz}, 1 \mathrm{H}) ;{ }^{13} \mathrm{C} \mathrm{NMR}(100$ $\mathrm{MHz}, \mathrm{CD}_{2} \mathrm{Cl}_{2}$ ): $\delta$ 139.2, 135.8, 127.6, 119.1, 113.6, 31.6, 14.1. ATR-FTIR (neat): 2964 (w, Ar-H), 2925 (w, Ar-H), $2131\left(\mathrm{~m}, \mathrm{~N}_{3}\right), 2098\left(\mathrm{~s}, \mathrm{~N}_{3}\right), 2042\left(\mathrm{w}, \mathrm{N}_{3}\right), 1602(\mathrm{~m}), 1571$ (s), 1292 (s), 836 (s) cm ${ }^{-1}$. HRMS (EI) $\mathrm{m} / \mathrm{z}$ calculated for $\mathrm{C}_{8} \mathrm{H}_{7} \mathrm{~N}_{3}[\mathrm{M}]^{+}:$: 145.0640; found: 145.0638 .

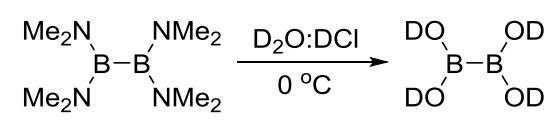

Tetradeuteroxydiboron: Modifying the literature procedure used for the synthesis of tetrahydroxydiboron, ${ }^{6}$ a $50 \mathrm{~mL}$ Schlenk flask fitted with a dropping funnel was placed in an oil bath at 95 ${ }^{\circ} \mathrm{C}$ and evacuated under vacuum for 3 hours. To the flask, $10 \mathrm{~mL}$ of deuterium oxide $(99.9 \% \mathrm{D}$; Sigma Aldrich) and $5.4 \mathrm{~mL}$ of tetrakis(dimethylamino) diboron $(25.3 \mathrm{mmol})$ were added. The flask was then placed in an ice bath. Via the drop funnel, $15 \mathrm{~mL}$ of $\mathrm{D}_{2} \mathrm{O}$ and $9.5 \mathrm{~mL}$ of a $11 \mathrm{M}$ deuterium chloride solution were added over 30 minutes resulting in a white precipitate. The reaction was allowed to warm to room temperature while stirring for one hour. The reaction was filtered through a fine frit and the precipitate washed with $5 \mathrm{~mL}$ of a $10 \% \mathrm{DCl}: \mathrm{D}_{2} \mathrm{O}$ solution followed by $5 \mathrm{~mL}$ of $\mathrm{CDCl}_{3}$. The precipitate 
was dried under high-vac for 2 hours resulting in $1.57 \mathrm{~g}(67 \%)$ of a white solid with no detectable proton inclusion by ${ }^{1} \mathrm{H}$ NMR. ${ }^{1} \mathrm{H}$ NMR $\left(500 \mathrm{MHz},\left(\mathrm{CD}_{3}\right)_{2} \mathrm{SO}\right): \delta$ none detected; ${ }^{11} \mathrm{~B} \mathrm{NMR}(160 \mathrm{MHz}$, $\left(\mathrm{CD}_{3}\right)_{2} \mathrm{SO}$ ); $\delta$ 31.3. ATR-FTIR (neat): 2477 (s - OD sym. st); 2399 (s - OD assym. st); 1286 (s); 1147 (s); $925.7(\mathrm{~s}) ; 804(\mathrm{~s}) ; 634(\mathrm{~s}) \mathrm{cm}^{-1}$. For comparison, the ${ }^{1} \mathrm{H}$ NMR spectrum of $\mathrm{B}_{2}(\mathrm{OH})_{4}$ as purchased from Strem Chemical, as well as the ${ }^{1} \mathrm{H}$ NMR spectrum of $\mathrm{B}_{2}(\mathrm{OD})_{4}$ synthesized using $99 \%$ D deuterium oxide (which resulted in 7\% $\mathrm{H}$ incorporation) are also provided in Section VI.

\section{Palladium Catalyzed Transfer Hydrogenation}

\section{A. General Procedure for Reaction Optimization}

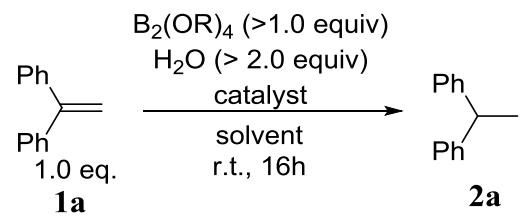

General Optimization Procedure: To a 1 dram vial equipped with a stir bar, $59.4 \mathrm{mg}$ of tetrahydroxydiboron $(0.66 \mathrm{mmols})$ and $61.2 \mathrm{mg}$ of $5 \% \mathrm{Pd} / \mathrm{C}(0.029 \mathrm{mmol})$ were added. The vial was capped with a septum, degassed and backfilled with argon. The vial was charged with $1 \mathrm{~mL}$ of DCM and $108.0 \mathrm{mg}$ 1,1-diphenylethylene $1 \mathrm{a}(0.6 \mathrm{mmol})$. Lastly, water was added prior to stirring at $600 \mathrm{rpms}$ overnight. After 18 hours, the solution was filtered through a Celite ${ }^{\circledR}$ plug and thoroughly washed with DCM. Solvent was removed and the reaction yield determined by ${ }^{1} \mathrm{H}$ NMR yield using 1,3,5trimethoxybenzene. 
B. Tabulation of Optimization Trials

\begin{tabular}{|c|c|c|c|c|c|c|}
\hline Trial $^{\mathbf{a}}$ & Solvent & Diboron & Additive & Catalyst & Water & \% Yield \\
\hline 1 & Toluene & $\mathrm{B}_{2}(\mathrm{OH})_{4}$ & TEA & $\mathrm{Pd} / \mathrm{C}$ & $11 \mathrm{eq}$. & 72 \\
\hline 2 & EtOAc & $\mathrm{B}_{2}(\mathrm{OH})_{4}$ & TEA & $\mathrm{Pd} / \mathrm{C}$ & 11 eq. & 77 \\
\hline 3 & 2-MeTHF & $\mathrm{B}_{2}(\mathrm{OH})_{4}$ & TEA & $\mathrm{Pd} / \mathrm{C}$ & 11 eq. & 99 \\
\hline 4 & Toluene & $\mathrm{B}_{2}(\mathrm{cat})_{2}$ & TEA & $\mathrm{Pd} / \mathrm{C}$ & $11 \mathrm{eq}$. & 63 \\
\hline 5 & EtOAc & $\mathrm{B}_{2}(\mathrm{cat})_{2}$ & TEA & $\mathrm{Pd} / \mathrm{C}$ & 11 eq. & 66 \\
\hline 6 & DCM & $\mathrm{B}_{2}(\mathrm{cat})_{2}$ & TEA & $\mathrm{Pd} / \mathrm{C}$ & $11 \mathrm{eq}$. & 47 \\
\hline 7 & $\mathrm{MeCN}$ & $\mathrm{B}_{2}(\mathrm{cat})_{2}$ & TEA & $\mathrm{Pd} / \mathrm{C}$ & 11 eq. & 98 \\
\hline 8 & 2-MeTHF & $\mathrm{B}_{2}(\mathrm{cat})_{2}$ & TEA & $\mathrm{Pd} / \mathrm{C}$ & 11 eq. & Quant. \\
\hline 9 & 2-MeTHF & $\mathrm{B}_{2}(\operatorname{pin})_{2}$ & TEA & $\mathrm{Pd} / \mathrm{C}$ & $11 \mathrm{eq}$. & 13 \\
\hline 10 & 2-MeTHF & $\mathrm{B}_{2}(\mathrm{OH})_{4}$ & $\mathrm{Na}_{2} \mathrm{CO}_{3}$ & $\mathrm{Pd}(\mathrm{OAc})_{2}{ }^{\mathrm{b}}$ & $11 \mathrm{eq}$. & 46 \\
\hline 11 & DCM & $\mathrm{B}_{2}(\mathrm{OH})_{4}$ & $\mathrm{Na}_{2} \mathrm{CO}_{3}$ & $\mathrm{Pd}(\mathrm{OAc})_{2}{ }^{\mathrm{b}}$ & $11 \mathrm{eq}$. & 36 \\
\hline 12 & Toluene & $\mathrm{B}_{2}(\mathrm{OH})_{4}$ & $\mathrm{Na}_{2} \mathrm{CO}_{3}$ & $\mathrm{Pd}(\mathrm{OAc})_{2}{ }^{\mathrm{b}}$ & $11 \mathrm{eq}$. & 39 \\
\hline 13 & 2-MeTHF & $\mathrm{B}_{2}(\mathrm{OH})_{4}$ & $\mathrm{Na}_{2} \mathrm{CO}_{3}$ & $\mathrm{Pd} / \mathrm{C}$ & $11 \mathrm{eq}$. & 70 \\
\hline 14 & DCM & $\mathrm{B}_{2}(\mathrm{OH})_{4}$ & $\mathrm{Na}_{2} \mathrm{CO}_{3}$ & $\mathrm{Pd} / \mathrm{C}$ & 11 eq. & 96 \\
\hline 15 & Toluene & $\mathrm{B}_{2}(\mathrm{OH})_{4}$ & $\mathrm{Na}_{2} \mathrm{CO}_{3}$ & $\mathrm{Pd} / \mathrm{C}$ & 11 eq. & 81 \\
\hline 16 & Toluene & $\mathrm{B}_{2}(\mathrm{OH})_{4}$ & $\mathrm{Na}_{2} \mathrm{CO}_{3}$ & $\mathrm{Pd} / \mathrm{C}$ & 0 eq. & 0 \\
\hline 17 & Toluene & $\mathrm{B}_{2}(\mathrm{OH})_{4}$ & TEA & $\mathrm{Pd} / \mathrm{C}$ & 0 eq. & 3 \\
\hline 18 & 2-MeTHF & $\mathrm{B}_{2}(\mathrm{OH})_{4}$ & $\mathrm{Na}_{2} \mathrm{CO}_{3}$ & $\mathrm{Pd} / \mathrm{C}$ & 0 eq. & 28 \\
\hline 19 & 2-MeTHF & $\mathrm{B}_{2}(\mathrm{OH})_{4}$ & TEA & $\mathrm{Pd} / \mathrm{C}$ & 0 eq. & 36 \\
\hline 20 & DCM & $\mathrm{B}_{2}(\mathrm{OH})_{4}$ & $\mathrm{Na}_{2} \mathrm{CO}_{3}$ & $\mathrm{Pd} / \mathrm{C}$ & 0 eq. & 0 \\
\hline 21 & $\mathrm{DCM}$ & $\mathrm{B}_{2}(\mathrm{OH})_{4}$ & TEA & $\mathrm{Pd} / \mathrm{C}$ & 0 eq. & 16 \\
\hline 22 & $\mathrm{MeOH}$ & $\mathrm{B}_{2}(\mathrm{OH})_{4}$ & TEA & $\mathrm{Pd} / \mathrm{C}$ & 0 eq. & 43 \\
\hline 23 & 2-MeBuOH & $\mathrm{B}_{2}(\mathrm{OH})_{4}$ & TEA & $\mathrm{Pd} / \mathrm{C}$ & 0 eq. & 71 \\
\hline $24^{\mathrm{c}}$ & DCM & $\mathrm{B}_{2}(\mathrm{OH})_{4}$ & None & $\mathrm{Pd} / \mathrm{C}$ & 2 eq. & Quant. \\
\hline $25^{\mathrm{c}}$ & $\mathrm{DCM}$ & $\mathrm{B}_{2}(\mathrm{OH})_{4}$ & None & $\mathrm{Pd} / \mathrm{C}$ & 10 eq. & Quant. \\
\hline $26^{\mathrm{c}}$ & DCM & $\mathrm{B}_{2}(\mathrm{OH})_{4}$ & None & $\mathrm{Pd} / \mathrm{C}$ & 20 eq. & Quant. \\
\hline 27 & DCM & $\mathrm{B}_{2}(\mathrm{OH})_{4}$ & None & $\mathrm{RuCl}_{2}(\mathrm{PPh})_{3}$ & 5 eq. & 0 \\
\hline 28 & $\mathrm{DCM}$ & $\mathrm{B}_{2}(\mathrm{OH})_{4}$ & None & $\mathrm{NiCl}_{2}$ & 5 eq. & 0 \\
\hline 29 & DCM & $\mathrm{B}_{2}(\mathrm{OH})_{4}$ & None & $\mathrm{NiCl}_{2}: \mathrm{PPh}_{3}$ & 5 eq. & 0 \\
\hline 30 & $\mathrm{MeOH}$ & $\mathrm{B}_{2}(\mathrm{OH})_{4}$ & None & $\mathrm{Pd} / \mathrm{C}$ & 0 eq. & Quant. \\
\hline 31 & 2-MeBuOH & $\mathrm{B}_{2}(\mathrm{OH})_{4}$ & None & $\mathrm{Pd} / \mathrm{C}$ & 0 eq. & 6 \\
\hline 32 & THF & $\mathrm{B}_{2}(\mathrm{OH})_{4}$ & None & $\mathrm{Pd} / \mathrm{C}$ & 0 eq. & Quant. \\
\hline 33 & 2-MeTHF & $\mathrm{B}_{2}(\mathrm{OH})_{4}$ & None & $\mathrm{Pd} / \mathrm{C}$ & 0 eq. & 11 \\
\hline 34 & DCM & $\mathrm{B}_{2}(\mathrm{OH})_{4}$ & None & $\mathrm{Pt} / \mathrm{C}$ & 5 eq. & 94 \\
\hline 35 & $\mathrm{DCM}$ & $\mathrm{B}_{2}(\mathrm{OH})_{4}$ & None & $\mathrm{Ru} / \mathrm{C}$ & 5 eq. & 73 \\
\hline 36 & $\mathrm{DCM}$ & $\mathrm{B}_{2}(\mathrm{OH})_{4}$ & None & $\mathrm{Rh} / \mathrm{C}$ & 5 eq. & 98 \\
\hline 37 & DCM & $\mathrm{B}_{2}(\mathrm{OH})_{4}$ & None & $\mathrm{Ir} / \mathrm{C}^{\mathrm{d}}$ & 5 eq. & $<1$ \\
\hline $38^{\mathrm{e}}$ & $\mathrm{DCM}$ & $\mathrm{B}_{2}(\mathrm{OH})_{4}$ & None & $\mathrm{Pd} / \mathrm{C}$ & 5 eq. & Quant. \\
\hline $39^{\mathrm{h}}$ & DCM & $\mathrm{B}_{2}(\mathrm{OH})_{4}$ & BINAP $^{f}$ & $\mathrm{Pd}(\mathrm{OAc})_{2}$ & 5 eq. & $0 \%$ \\
\hline $40^{\mathrm{h}}$ & DCM & $\mathrm{B}_{2}(\mathrm{OH})_{4}$ & None & $\mathrm{Pd}(\mathrm{dppf})_{2}$ & 5 eq. & $0 \%$ \\
\hline $41^{\mathrm{h}}$ & DCM & $\mathrm{B}_{2}(\mathrm{OH})_{4}$ & $\mathrm{Bppb}^{\mathrm{g}}$ & $\mathrm{Pd}(\mathrm{OAc})_{2}$ & 5 eq. & $0 \%$ \\
\hline
\end{tabular}

${ }^{\mathrm{a}} 0.2 \mathrm{mmol}$ of 1,1-diphenylethylene, 1.1 eq. diboron, $5 \mathrm{~mol} \%$ catalyst loading and $1 \mathrm{~mL}$ of solvent were reacted in a vial at R.T. for 18 hours; ${ }^{b} 2.5 \mathrm{~mol} \%$ catalyst; ${ }^{\mathrm{c}}$ styrene was the reagent tested for hydrogenation; ${ }^{\mathrm{d}}$ catalyst was reduced; ${ }^{\mathrm{e}}$ reaction was stirred in open air overnight with minimal conversion, water was added and the reaction allowed to stir another 5 hours open to air affording full conversion. ${ }^{\mathrm{f}} 2,2^{\prime}-$ bis(diphenylphosphino)-1,1'-binaphthyl; ${ }^{\mathrm{g}} \mathrm{bppb}=$ bis(diphenylphosphino) butane; ${ }^{\mathrm{h}}$ Reactions were allowed to stir for 5 minutes prior to adding water 


\section{Optimized General Procedure}

General Optimization Procedure: To a 1 dram vial $(3.7 \mathrm{~mL})$ equipped with a micro stir bar was added $59.4 \mathrm{mg}$ of tetrahydroxydiboron (1.1 equiv, $0.66 \mathrm{mmols})$ and $63.8 \mathrm{mg}$ unreduced $\mathrm{Pd} / \mathrm{C}(5 \mathrm{~mol} \%, 0.03$ mmols). The vial was capped with a septum, degassed and backfilled with argon. The vial was charged with $2.0 \mathrm{~mL}$ of dichloromethane followed with $108 \mathrm{mg}$ of 1,1-diphenylethylene 1a $(0.6 \mathrm{mmols}, 1.0$ equiv). Lastly, $50 \mu \mathrm{L}$ of water was added prior to stirring at $600 \mathrm{rpm}$ overnight. After 5 hours, the solution was filtered through a Celite ${ }^{\circledR}$ plug and washed with DCM. ${ }^{1} \mathrm{H}(\mathrm{PRESAT}) \mathrm{NMR}$ were obtained with the integral ratios being used to determine starting material conversion. When incomplete conversion is observed and products could not be separated from the starting materials, NMR yields were obtained using 1,3,5-trimethoxybenzene as an internal standard in $\mathrm{CH}_{2} \mathrm{Cl}_{2}$ or $\mathrm{CDCl}_{3}$ for non-volatile products. For starting materials consumed in full, the product was isolated by solvent removal in vacuo. For volatile products NMR yield was obtained by adding a known amount of 1,3,5-trimethoxybenzene to the vial after 5 hours. An aliquot was filtered through a $0.2 \mu \mathrm{M}$ syringe filter (SLFGR04NL) and ${ }^{1} \mathrm{H}$ NMR obtained using H(PRESAT) solvent suppression. To obtain accurate integral ratios for NMR yields using H(PRESAT), it was determined that an extended relaxation time was required, up to 20 seconds.

\section{Scope and Limitations of the Hydrogenation of 1a-1ag}

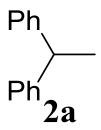

1,1-Diphenylethane 2a. The general procedure was scaled to $1.034 \mathrm{~g}$ of 1,1-diphenylethylene 1a (5.74 mmol, 1.0 eq.), $540 \mathrm{mg}$ of tetrahydroxydiboron (5.99 mmol, 1.04 eq.), $40.0 \mathrm{mg}$ of $10 \% \mathrm{Pd} / \mathrm{C}(0.038$ $\mathrm{mmol}$ ), $10 \mathrm{~mL}$ of DCM, and $500 \mathrm{mg}$ of $\mathrm{H}_{2} \mathrm{O}$. The reaction was monitored by ${ }^{1} \mathrm{H}(\mathrm{PRESAT}) \mathrm{NMR}$ and determined to be complete after 60 hours. The reaction was filtered through a Celite ${ }^{\circledR}$ pad and washed with dichloromethane. ${ }^{1} \mathrm{H}$ NMR spectroscopy $\left(400 \mathrm{MHz}, \mathrm{CH}_{2} \mathrm{Cl}_{2}\right.$ ) revealed complete consumption of 1a. Solvent was then removed in vacuo to yield $962.3 \mathrm{mg}$ of $\mathbf{2 a}$ as a colorless oil (5.29 mmol, 92\%). NMR data obtained are consistent with previous literature. ${ }^{7}{ }^{1} \mathrm{H} \mathrm{NMR}\left(400 \mathrm{MHz}, \mathrm{CH}_{2} \mathrm{Cl}_{2}\right): \delta 7.32-7.23(\mathrm{~m}, 8 \mathrm{H})$, 7.21-7.16 (m, 2H), 4.17 (q, $J=7.2 \mathrm{~Hz}, 1 \mathrm{H}), 1.65$ (d, $J=7.2 \mathrm{~Hz}, 3 \mathrm{H}) ;{ }^{13} \mathrm{C}$ NMR $\left(100 \mathrm{MHz}, \mathrm{CH}_{2} \mathrm{Cl}_{2}\right): \delta$ $146.7,128.5,127.7,126.1,45.0,21.7$.

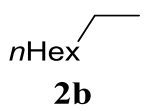

Octane $2 \mathbf{b}$. The general procedure was followed using $59.5 \mathrm{mg}$ of tetrahydroxydiboron ( $0.66 \mathrm{mmol}), 31.7$ $\mathrm{mg}$ of $10 \% \mathrm{Pd} / \mathrm{C}(0.030 \mathrm{mmol}), 2 \mathrm{~mL}$ of DCM, $71.7 \mathrm{mg}$ of 1 -octene $1 \mathbf{b}(0.63 \mathrm{mmol})$ and $50 \mu \mathrm{L} \mathrm{of} \mathrm{H}_{2} \mathrm{O}$. ${ }^{1} \mathrm{H}$ NMR spectroscopy (400 $\mathrm{MHz}, \mathrm{CH}_{2} \mathrm{Cl}_{2}$ ) revealed complete consumption of $\mathbf{1 b}$ and a $95 \%$ NMR yield of 2b. NMR data obtained are consistent with the literature. ${ }^{8}{ }^{1} \mathrm{H}$ NMR $\left(400 \mathrm{MHz}, \mathrm{CH}_{2} \mathrm{Cl}_{2}\right): \delta 1.26(\mathrm{~m}$, $12 \mathrm{H}), 0.87(\mathrm{t}, J=6.8 \mathrm{~Hz}, 4 \mathrm{H}) ;{ }^{13} \mathrm{C} \mathrm{NMR}\left(100 \mathrm{MHz}, \mathrm{CH}_{2} \mathrm{Cl}_{2}\right): \delta 32.1,29.5,22.9,14.0$.

$$
\underset{2 \mathrm{c}}{\mathrm{HO}+\mathrm{T}_{3}}
$$

1-Pentanol 2c. The general procedure was followed using $61.5 \mathrm{mg}$ of tetrahydroxydiboron $(0.68 \mathrm{mmol})$, $32.0 \mathrm{mg}$ of $10 \% \mathrm{Pd} / \mathrm{C}(0.030 \mathrm{mmol}), 2 \mathrm{~mL}$ of DCM, $55.0 \mathrm{mg}$ of 1 -pentene $1 \mathrm{c}(0.64 \mathrm{mmol})$ and $50 \mu \mathrm{L}$ of 
$\mathrm{H}_{2} \mathrm{O} .{ }^{1} \mathrm{H}$ NMR spectroscopy (400 MHz, $\mathrm{CH}_{2} \mathrm{Cl}_{2}$ ) revealed complete consumption of $1 \mathrm{c}$ and a $96 \% \mathrm{NMR}$ yield of 2c. NMR data obtained are consistent with the literature. ${ }^{9}{ }^{1} \mathrm{H}$ NMR $\left(400 \mathrm{MHz}, \mathrm{CH}_{2} \mathrm{Cl}_{2}\right): \delta 3.57$ $(\mathrm{t}, J=6.7 \mathrm{~Hz}, 2 \mathrm{H}), 1.73($ br $s, 1 \mathrm{H}), 1.52(\mathrm{~m}, 2 \mathrm{H}), 1.30(\mathrm{~m}, 4 \mathrm{H}), 0.89(\mathrm{t}, J=7.0 \mathrm{~Hz} ; 3 \mathrm{H}) ;{ }^{13} \mathrm{C}$ NMR $(100$ $\left.\mathrm{MHz}, \mathrm{CH}_{2} \mathrm{Cl}_{2}\right): \delta 62.9,32.7,28.1,22.7,14.0$

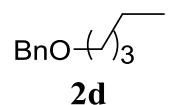

1-Benzyloxypentane 2d. The general procedure was followed using $30.4 \mathrm{mg}$ of tetrahydroxydiboron (0.34 mmol), $17 \mathrm{mg}$ of $10 \% \mathrm{Pd} / \mathrm{C}(0.016 \mathrm{mmol}), 2 \mathrm{~mL}$ of DCM, $55.8 \mathrm{mg}$ of 1-benzyloxy-4-pentene 1d $(0.31 \mathrm{mmol})$ and $50 \mu \mathrm{L}$ of $\mathrm{H}_{2} \mathrm{O} .{ }^{1} \mathrm{H}$ NMR spectroscopy $\left(400 \mathrm{MHz}, \mathrm{CH}_{2} \mathrm{Cl}_{2}\right.$ ) revealed complete consumption of $\mathbf{1 d}$. Solvent was then removed in vacuo to afford $54.1 \mathrm{mg}$ of $\mathbf{2 d}$ as a colorless oil (0.307 mmol, 97\%). NMR data obtained are consistent with the literature. ${ }^{10}{ }^{1} \mathrm{H}$ NMR $\left(400 \mathrm{MHz}, \mathrm{CDCl}_{3}\right): \delta$ $7.33-7.20(\mathrm{~m}, 5 \mathrm{H}), 4.51(\mathrm{~s}, 2 \mathrm{H}), 3.48(\mathrm{t}, J=6.6 \mathrm{~Hz}, 2 \mathrm{H}), 1.67-1.57(\mathrm{~m}, 4 \mathrm{H}), 1.39-1.29(\mathrm{~m}, 4 \mathrm{H}), 0.92(\mathrm{t}, J$ $=7.1 \mathrm{~Hz}, 3 \mathrm{H}) ;{ }^{13} \mathrm{C} \mathrm{NMR}\left(100 \mathrm{MHz}, \mathrm{CDCl}_{3}\right): \delta 138.7,128.3,127.6,127.5,106.6,72.7,70.5,29.5,28.5$, 22.6, 13.9 .

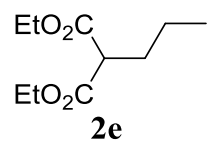

Diethyl 2-propylmalonate 2e. The general procedure was followed using $60.4 \mathrm{mg}$ of tetrahydroxydiboron $(0.67 \mathrm{mmol}), 28.1 \mathrm{mg}$ of $10 \% \mathrm{Pd} / \mathrm{C}(0.028 \mathrm{mmol}), 2 \mathrm{~mL}$ of DCM, $108.0 \mathrm{mg}$ of diethyl allylmalonate 1e $(0.54 \mathrm{mmol})$ and $50 \mu \mathrm{L}$ of $\mathrm{H}_{2} \mathrm{O} .{ }^{1} \mathrm{H}$ NMR spectroscopy $\left(400 \mathrm{MHz}, \mathrm{CH}_{2} \mathrm{Cl}_{2}\right)$ revealed complete consumption of 1e. Solvent was then removed in vacuo to yield $99.7 \mathrm{mg}$ of $\mathbf{2 e}$ as a colorless oil (0.49 mmol, 91\%). NMR data obtained are consistent with the literature. ${ }^{11}{ }^{1} \mathrm{H}$ NMR (400 $\left.\mathrm{MHz}, \mathrm{CDCl}_{3}\right): \delta 4.14(\mathrm{q}, J=7.1 \mathrm{~Hz}, 4 \mathrm{H}), 3.29(\mathrm{t}, J=7.6 \mathrm{~Hz}, 1 \mathrm{H}), 1.85-1.74(\mathrm{dt}, J=9.8,7.7 \mathrm{~Hz}, 2 \mathrm{H})$, $1.36-1.25(\mathrm{~m}, 2 \mathrm{H}), 1.22(\mathrm{t}, J=7.1 \mathrm{~Hz}, 6 \mathrm{H}), 0.91(\mathrm{t}, J=7.3 \mathrm{~Hz}, 3 \mathrm{H}) ;{ }^{13} \mathrm{C}$ NMR $\left(100 \mathrm{MHz}, \mathrm{CDCl}_{3}\right): \delta$ 169.6, 61.3, 51.9, 30.9, 20.7, 14.0, 13.7 .

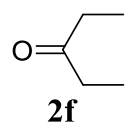

Diethylketone 2f. The general procedure was followed using $60.6 \mathrm{mg}$ of tetrahydroxydiboron $(0.67$ $\mathrm{mmol}), 27.0 \mathrm{mg}$ of $10 \% \mathrm{Pd} / \mathrm{C}(0.026 \mathrm{mmol}), 2 \mathrm{~mL}$ of DCM, $45.0 \mathrm{mg}$ of ethylvinylketone $\mathbf{1 f}(0.64 \mathrm{mmol})$ and $50 \mu \mathrm{L}$ of $\mathrm{H}_{2} \mathrm{O} .{ }^{1} \mathrm{H}$ NMR spectroscopy $\left(400 \mathrm{MHz}, \mathrm{CH}_{2} \mathrm{Cl}_{2}\right.$ ) revealed complete consumption of $\mathbf{1 f}$ and a 95\% NMR yield of 2f. NMR data obtained are consistent with the literature. ${ }^{12}{ }^{1} \mathrm{H}$ NMR (400 MHz, $\left.\mathrm{CH}_{2} \mathrm{Cl}_{2}\right): \delta 2.37(\mathrm{q}, J=7.3 \mathrm{~Hz}, 4 \mathrm{H}), 0.98(\mathrm{t}, J=7.3 \mathrm{~Hz}, 6 \mathrm{H}) ;{ }^{13} \mathrm{C} \mathrm{NMR}\left(100 \mathrm{MHz}, \mathrm{CH}_{2} \mathrm{Cl}_{2}\right): \delta 212.0,35.4$, 7.8 .

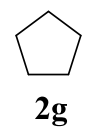

Cyclopentane 2g. The general procedure was followed using $60.6 \mathrm{mg}$ of tetrahydroxydiboron (0.67 $\mathrm{mmol}), 31.0 \mathrm{mg}$ of $10 \% \mathrm{Pd} / \mathrm{C}(0.030 \mathrm{mmol}), 2 \mathrm{~mL}$ of DCM, $42.4 \mathrm{mg}$ of cyclopentene $1 \mathrm{~g}(0.62 \mathrm{mmol})$ and $50 \mu \mathrm{L}$ of $\mathrm{H}_{2} \mathrm{O}$. ${ }^{1} \mathrm{H}$ NMR spectroscopy $\left(400 \mathrm{MHz}, \mathrm{CH}_{2} \mathrm{Cl}_{2}\right.$ ) revealed complete consumption of $\mathbf{1 g}$ and a 
95\% NMR yield of 2g. NMR data obtained are consistent with the literature. ${ }^{8}{ }^{1} \mathrm{H}$ NMR (400 MHz, $\left.\mathrm{CH}_{2} \mathrm{Cl}_{2}\right): \delta 1.49(\mathrm{~s}, 10 \mathrm{H}) ;{ }^{13} \mathrm{C} \mathrm{NMR}\left(100 \mathrm{MHz}, \mathrm{CH}_{2} \mathrm{Cl}_{2}\right): \delta 26.0$.

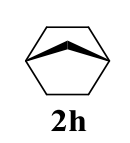

Norbornane $\mathbf{2 h}$. The general procedure was followed using $60.2 \mathrm{mg}$ of tetrahydroxydiboron $(0.67$ $\mathrm{mmol}), 32 \mathrm{mg}$ of $10 \% \mathrm{Pd} / \mathrm{C}(0.030 \mathrm{mmol}), 2 \mathrm{~mL}$ of DCM, $53.3 \mathrm{mg}$ of norbornene $\mathbf{1 h}(0.57 \mathrm{mmol})$ and $47.9 \mathrm{mg}$ of $\mathrm{H}_{2} \mathrm{O} .{ }^{1} \mathrm{H}$ NMR spectroscopy $\left(400 \mathrm{MHz}, \mathrm{CH}_{2} \mathrm{Cl}_{2}\right.$ ) revealed complete consumption of $\mathbf{1 h}$ and a 95\% NMR yield of $\mathbf{2 h}$. NMR data obtained are consistent with the literature. ${ }^{8}{ }^{1} \mathrm{H}$ NMR $(400 \mathrm{MHz}$, $\left.\mathrm{CH}_{2} \mathrm{Cl}_{2}\right): \delta 2.20-2.14(\mathrm{~m}, 2 \mathrm{H}), 1.50-1.42(\mathrm{~m}, 4 \mathrm{H}), 1.19-1.12(\mathrm{~m}, 6 \mathrm{H}) ;{ }^{13} \mathrm{C} \mathrm{NMR}\left(100 \mathrm{MHz}, \mathrm{CH}_{2} \mathrm{Cl}_{2}\right): \delta$ 36.2, 34.4, 27.6.

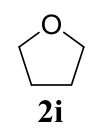

Tetrahydrofuran $2 \mathbf{i}$. The general procedure was followed using $59.1 \mathrm{mg}$ of tetrahydroxydiboron $(0.66$ $\mathrm{mmol}), 53.0 \mathrm{mg}$ of $5 \% \mathrm{Pd} / \mathrm{C}(0.025 \mathrm{mmol}), 2 \mathrm{~mL}$ of DCM, $45.0 \mathrm{mg}$ of 2,5-dihydrofuran $1 \mathbf{i}(0.64 \mathrm{mmol})$ and $50 \mu \mathrm{L}$ of $\mathrm{H}_{2} \mathrm{O}$. ${ }^{1} \mathrm{H}$ NMR spectroscopy $\left(400 \mathrm{MHz}, \mathrm{CH}_{2} \mathrm{Cl}_{2}\right)$ revealed complete consumption of $\mathbf{1 i}$ and a 99\% NMR yield of 2i. NMR data obtained are consistent with the literature. ${ }^{9,13}{ }^{1} \mathrm{H} \mathrm{NMR} \mathrm{(400} \mathrm{MHz,}$ $\left.\mathrm{CH}_{2} \mathrm{Cl}_{2}\right): \delta 3.70-3.64(\mathrm{~m}, 4 \mathrm{H}), 1.82-1.78(\mathrm{~m}, 4 \mathrm{H}) ;{ }^{13} \mathrm{C} \mathrm{NMR}\left(100 \mathrm{MHz}, \mathrm{CH}_{2} \mathrm{Cl}_{2}\right): \delta 67.9,25.7$.

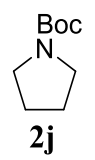

$\mathrm{N}$-Boc-pyrrolidine $\mathbf{2 j}$. The general procedure was scaled to react $943.6 \mathrm{mg}$ of $\mathrm{N}$-Boc-2,5-dihydropyrrole 1 j (5.55 mmol, 1.0 eq.) with $567.3 \mathrm{mg}$ of tetrahydroxydiboron (6.30 mmol, 1.13 eq.), $30.0 \mathrm{mg}$ of $10 \%$ $\mathrm{Pd} / \mathrm{C}(0.028 \mathrm{mmol})$ in $10 \mathrm{~mL}$ of DCM and $531 \mathrm{mg}$ of $\mathrm{H}_{2} \mathrm{O}$. The reaction was monitored by ${ }^{1} \mathrm{H}(\mathrm{PRESAT})$ NMR and determined to be complete after 60 hours. The reaction was filtered through a Celite ${ }^{\circledR}$ pad and washed with dichloromethane. ${ }^{1} \mathrm{H}$ NMR spectroscopy $\left(400 \mathrm{MHz}, \mathrm{CH}_{2} \mathrm{Cl}_{2}\right.$ ) revealed complete consumption of $\mathbf{1 j}$. Solvent was then removed in vacuo to yield $916.6 \mathrm{mg}$ of $\mathbf{2} \mathbf{j}$ as a colorless solid (5.36 mmol, 97\%). NMR data obtained are consistent with the literature. ${ }^{14}{ }^{1} \mathrm{H}$ NMR $\left(400 \mathrm{MHz}, \mathrm{CH}_{2} \mathrm{Cl}_{2}\right): \delta 3.23$ (br $s, 4 \mathrm{H}), 1.78$ (br $s, 4 \mathrm{H}), 1.40(\mathrm{~s}, 9 \mathrm{H}) ;{ }^{13} \mathrm{C} \mathrm{NMR}\left(100 \mathrm{MHz}, \mathrm{CH}_{2} \mathrm{Cl}_{2}\right): \delta 154.5,78.6,46.1,45.8,28.4$, $25.9,25.1$.

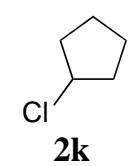

Chlorocyclopentane $2 \mathbf{k}$. The general procedure was followed using $59.5 \mathrm{mg}$ of tetrahydroxydiboron (0.66 mmol), $29.1 \mathrm{mg}$ of $10 \% \mathrm{Pd} / \mathrm{C}(0.029 \mathrm{mmol}), 2 \mathrm{~mL}$ of DCM, $63.5 \mathrm{mg}$ of 1-chloro-1-cyclopentene 1k ( $0.61 \mathrm{mmol}$ ) and $55.0 \mathrm{mg}$ of $\mathrm{H}_{2} \mathrm{O} .{ }^{1} \mathrm{H} \mathrm{NMR}$ spectroscopy $\left(400 \mathrm{MHz}, \mathrm{CH}_{2} \mathrm{Cl}_{2}\right.$ ) revealed $64 \%$ consumption of $1 \mathbf{k}$ and a corresponding mixture of cyclopentane (55\%), cyclopentene (8\%), and trace chlorocyclopentane $\mathbf{2 k}$. 


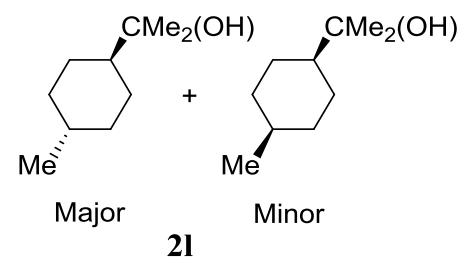

trans-4-methyl-1-(1-hydroxy-1-methylethyl)cyclohexane and cis-4-methyl-1-(1-hydroxy-1methylethyl)cyclohexane 2l. The general procedure was followed using $59.4 \mathrm{mg}$ of tetrahydroxydiboron (0.66 mmol), $32.2 \mathrm{mg}$ of $10 \% \mathrm{Pd} / \mathrm{C}(0.030 \mathrm{mmol}), 2 \mathrm{~mL}$ of DCM, $91.0 \mathrm{mg}$ of (+)- $\alpha$-terpineol 11 (0.60 mmol) and $49.9 \mathrm{mg}$ of $\mathrm{H}_{2} \mathrm{O}$. ${ }^{1} \mathrm{H} \mathrm{NMR}$ spectroscopy $\left(400 \mathrm{MHz}, \mathrm{CH}_{2} \mathrm{Cl}_{2}\right.$ ) revealed complete consumption of $\mathbf{1 l}$ and a 69\% combined NMR yield of trans-2l and cis-2l, which were inseparable by column chromatography. NMR data for the mixture are consistent with the literature. ${ }^{15}{ }^{1} \mathrm{H}$ NMR $(500 \mathrm{MHz}$, $\left.\mathrm{CDCl}_{3}\right): \delta 1.83-1.70\left(\mathrm{~m}, 3.5 \mathrm{H}^{*}\right), 1.30-1.16(\mathrm{~m}, 3 \mathrm{H}), 1.15$ and 1.14 (s, cis- and trans-, respectively, $\left.6 \mathrm{H}\right)$, $1.03(\mathrm{q}, J=12.5 \mathrm{~Hz}, 2 \mathrm{H}), 0.93(\mathrm{~d}, J=7.2,1 \mathrm{H}), 0.86(\mathrm{~d}, J=6.6 \mathrm{~Hz}, 1 \mathrm{H}) ;{ }^{13} \mathrm{C} \mathrm{NMR}\left(125 \mathrm{MHz}, \mathrm{CDCl}_{3}\right): \delta$ 73.0 (cis), 73.0 (trans), 49.6 (cis), 48.9 (trans), 35.4, 32.8, 32.0, 27.5, 27.0, 26.9, 26.8, 22.6, 21.4, 17.5. A 25:75 ratio of cis:trans isomers is established by integrating the ${ }^{13} \mathrm{C}$ NMR peaks at 73.0:73.0 ppm and 49.6:48.9 ppm, and also confirmed by GC. ${ }^{15} *$ A low value is consistent with the literature.

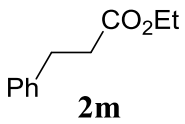

Ethyl 3-phenylproponate 2m. The general procedure was followed using $59.4 \mathrm{mg}$ of tetrahydroxydiboron $(0.66 \mathrm{mmol}), 31.7 \mathrm{mg}$ of $10 \% \mathrm{Pd} / \mathrm{C}(0.030 \mathrm{mmol}), 2 \mathrm{~mL}$ of DCM, $107.0 \mathrm{mg}$ of ethyl cinnamate $1 \mathrm{~m}(0.61 \mathrm{mmol})$ and $50 \mu \mathrm{L}$ of $\mathrm{H}_{2} \mathrm{O}$. ${ }^{1} \mathrm{H}$ NMR spectroscopy $\left(400 \mathrm{MHz}, \mathrm{CH}_{2} \mathrm{Cl}_{2}\right)$ revealed complete consumption of $\mathbf{1 m}$. Solvent was then removed in vacuo to yield $97.4 \mathbf{m g}$ of $\mathbf{2} \mathbf{m}$ as a colorless oil (0.574 mmol, 90\%). NMR data obtained are consistent with the literature. ${ }^{16}{ }^{1} \mathrm{H}$ NMR (400 MHz, $\left.\mathrm{CDCl}_{3}\right): \delta 7.34-7.27(\mathrm{~m}, 2 \mathrm{H}), 7.25-7.18(\mathrm{~m}, 3 \mathrm{H}), 4.15(\mathrm{t}, J=7.1 \mathrm{~Hz}, 2 \mathrm{H}), 2.97(\mathrm{t}, J=7.8 \mathrm{~Hz}, 2 \mathrm{H}), 2.64$ $(\mathrm{t}, J=7.8 \mathrm{~Hz}, 2 \mathrm{H}), 1.25(\mathrm{t}, J=7.1 \mathrm{~Hz}, 3 \mathrm{H}) ;{ }^{13} \mathrm{C} \mathrm{NMR}\left(100 \mathrm{MHz}, \mathrm{CDCl}_{3}\right): \delta 172.9,140.6,128.5,128.4$, $126.3,60.4,36.0,31.0,14.3$.

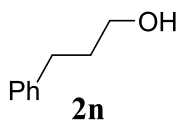

3-Phenylpropan-1-ol 2n. The general procedure was followed using $59.2 \mathrm{mg}$ of tetrahydroxydiboron (0.66 mmol), $30.1 \mathrm{mg}$ of $10 \% \mathrm{Pd} / \mathrm{C}(0.030 \mathrm{mmol}), 2 \mathrm{~mL}$ of DCM, $80.5 \mathrm{mg}$ of cinnamyl alcohol $\mathbf{1 n}(0.60$ mmol) and $54.0 \mathrm{mg}$ of $\mathrm{H}_{2} \mathrm{O} .{ }^{1} \mathrm{H}$ NMR spectroscopy $\left(400 \mathrm{MHz}, \mathrm{CH}_{2} \mathrm{Cl}_{2}\right.$ ) revealed $58 \%$ consumption of 1 n and a 21\% NMR yield of 3-phenylpropan-1-ol 2n. $\left.{ }^{17}{ }^{1} \mathrm{H} \mathrm{NMR} \mathrm{(400} \mathrm{MHz,} \mathrm{CDCl}_{3}\right): \delta 7.49-7.14(\mathrm{~m}, 5 \mathrm{H})$, $3.65(\mathrm{t}, J=6.5 \mathrm{~Hz}, 2 \mathrm{H}), 2.71(\mathrm{q}, J=7.7 \mathrm{~Hz}, 2 \mathrm{H}), 1.92-1.84(\mathrm{~m}, 2 \mathrm{H}),{ }^{13} \mathrm{C} \mathrm{NMR}\left(100 \mathrm{MHz} \mathrm{CDCl}_{3}\right): \delta$ $141.9,128.6,128.4,125.9,62.2,34.3,32.1$. By comparison to the literature, the remaining inseparable products are 3-cinnamaldehyde (32\%) and detectable amounts of 3-phenylpropanal. 


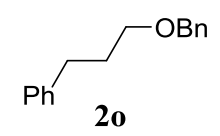

(3-(Benzyloxy)propyl)benzene 20. The general procedure was followed using $59.6 \mathrm{mg}$ of tetrahydroxydiboron $(0.66 \mathrm{mmol}), 52.3 \mathrm{mg}$ of $5 \% \mathrm{Pd} / \mathrm{C}(0.030 \mathrm{mmol}), 2 \mathrm{~mL}$ of DCM, $135 \mathrm{mg}$ of benzyl cinnamyl ether $10(0.60 \mathrm{mmol})$ and $52 \mathrm{mg}$ of $\mathrm{H}_{2} \mathrm{O}$. ${ }^{1} \mathrm{H}$ NMR spectroscopy $\left(400 \mathrm{MHz}, \mathrm{CH}_{2} \mathrm{Cl}_{2}\right)$ revealed 93\% consumption of $\mathbf{1 0}$ and a 90\% NMR yield of 2o. NMR data is consistent with the literature. ${ }^{18}{ }^{1} \mathrm{H}$ NMR (400 MHz, $\left.\mathrm{CH}_{2} \mathrm{Cl}_{2}\right): \delta 7.49-7.14(\mathrm{~m}, 10 \mathrm{H}), 4.51(\mathrm{~s}, 2 \mathrm{H}), 3.51(\mathrm{t}, J=6.3,2 \mathrm{H}), 2.80(\mathrm{t}, J=7.8 \mathrm{~Hz}$, $2 \mathrm{H}), 1.99-1.87$ (m 2H). ${ }^{13} \mathrm{C}$ NMR $\left(100 \mathrm{MHz}, \mathrm{CH}_{2} \mathrm{Cl}_{2}\right): \delta 142.1,138.6,128.6,128.5,128.4,127.8,127.7$, 125.9, 73.0, 69.6, 32.5, 31.5.

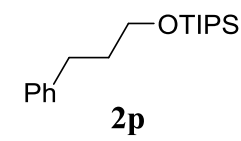

Triisopropyl(3-phenylpropoxy)silane 2p. The general procedure was followed using $30.1 \mathrm{mg}$ of tetrahydroxydiboron $(0.33 \mathrm{mmol}), 15.3 \mathrm{mg}$ of $10 \% \mathrm{Pd} / \mathrm{C}(0.015 \mathrm{mmol}), 2 \mathrm{~mL}$ of DCM, $85.2 \mathrm{mg}$ of cinnamyloxy(TIPS) $1 \mathbf{p}(0.30 \mathrm{mmol})$ and $53.0 \mathrm{mg}$ of $\mathrm{H}_{2} \mathrm{O} .{ }^{1} \mathrm{H}$ NMR spectroscopy $\left(400 \mathrm{MHz}, \mathrm{CH}_{2} \mathrm{Cl}_{2}\right)$ revealed complete consumption of $\mathbf{1 p}$. Solvent was then removed in vacuo to yield $81.2 \mathrm{mg}$ of $\mathbf{2 p}$ as a colorless oil $(0.278 \mathrm{mmol}, 95 \%)$. The NMR of the reduced product is consistent with the literature. ${ }^{4} \mathrm{H}$ NMR (400 MHz, $\left.\mathrm{CDCl}_{3}\right): \delta 7.34-7.16(\mathrm{~m}, 5 \mathrm{H}), 3.74(\mathrm{t}, J=6.3 \mathrm{~Hz}, 2 \mathrm{H}), 2.71(\mathrm{t}, J=7.8 \mathrm{~Hz}, 2 \mathrm{H}), 1.88-$ $1.79(\mathrm{~m}, 2 \mathrm{H}), 1.09-1.03(\mathrm{~m}, 21 \mathrm{H}) ;{ }^{13} \mathrm{C} \mathrm{NMR}\left(100 \mathrm{MHz}, \mathrm{CDCl}_{3}\right): \delta 142.4,128.5,128.3,125.6,62.6,34.7$, $32.1,18.1,12.0$.

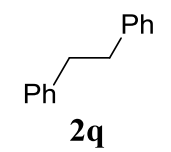

Reduction of trans-stilbene to 1,2-diphenylethane 2q. The general procedure was scaled to $1.035 \mathrm{~g}$ of trans-stilbene 1q $(5.74 \mathrm{mmol}, 1.0$ eq.), $567.7 \mathrm{mg}$ of tetrahydroxydiboron (6.30 mmol, 1.09 eq.), $30.2 \mathrm{mg}$ of $10 \% \mathrm{Pd} / \mathrm{C}(0.028 \mathrm{mmol}), 10 \mathrm{~mL}$ DCM and $532 \mathrm{mg}$ of $\mathrm{H}_{2} \mathrm{O}$. The reaction was monitored by ${ }^{1}$ H(PRESAT) NMR and determined to be complete after 90 hours. The reaction was filtered through a Celite ${ }^{\circledR}$ pad and washed with dichloromethane. ${ }^{1} \mathrm{H}$ NMR spectroscopy (400 $\mathrm{MHz}, \mathrm{CH}_{2} \mathrm{Cl}_{2}$ ) revealed complete consumption of 1q. Solvent was then removed in vacuo to yield $1.011 \mathrm{~g}$ of $\mathbf{2 q}$ as a colorless solid (5.55 mmol, 97\%). NMR data obtained are consistent with the literature. ${ }^{19}{ }^{1} \mathrm{H}$ NMR (400 MHz, $\mathrm{CH}_{2} \mathrm{Cl}_{2}$ ): $\delta$ 7.29-7.25 (m, 4H), 7.21-7.16 (m, 6H), $2.92(\mathrm{~s}, 4 \mathrm{H}) ;{ }^{13} \mathrm{C}$ NMR (100 MHz, $\left.\mathrm{CH}_{2} \mathrm{Cl}_{2}\right): \delta 142.1$, $128.6,128.4,125.0,38.0$.

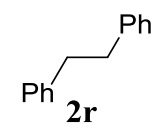

Reduction of cis-stilbene to 1,2-diphenylethane 2r. The general procedure was followed using $59.4 \mathrm{mg}$ of tetrahydroxydiboron $(0.66 \mathrm{mmol}), 57.0 \mathrm{mg}$ of $5 \% \mathrm{Pd} / \mathrm{C}(0.030 \mathrm{mmol}), 2 \mathrm{~mL}$ of DCM, $108 \mathrm{mg}$ of cisstilbene $1 \mathbf{r}(0.60 \mathrm{mmol})$ and $50 \mu \mathrm{L}$ of $\mathrm{H}_{2} \mathrm{O}$. ${ }^{1} \mathrm{H}$ NMR spectroscopy $\left(400 \mathrm{MHz}, \mathrm{CH}_{2} \mathrm{Cl}_{2}\right)$ revealed complete consumption of $\mathbf{1 r}$. Solvent was then removed in vacuo to yield $103.2 \mathrm{mg}$ of $\mathbf{2 r}$ as a colorless solid (0.567 mmol, 95\%).. NMR data obtained are consistent with the literature. ${ }^{19}{ }^{1} \mathrm{H}$ NMR (400 $\left.\mathrm{MHz}, \mathrm{CDCl}_{3}\right): \delta$ 
7.33-7.29 (m, 4H), 7.24-7.19 (m, 6H), 3.07 (s, 4H); ${ }^{13} \mathrm{C}$ NMR (100 MHz, $\left.\mathrm{CDCl}_{3}\right): \delta 141.9,128.6,128.5$, 126.1, 38.1.

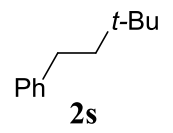

1-Phenyl-3,3-dimethylbutane 2s. The general procedure was followed using $29.1 \mathrm{mg}$ of tetrahydroxydiboron (0.32 mmol), $12.8 \mathrm{mg}$ of $5 \% \mathrm{Pd} / \mathrm{C}(0.008 \mathrm{mmol}), 2 \mathrm{~mL}$ of DCM, $40.6 \mathrm{mg}$ of trans-1phenyl-3,3-dimethyl-1-butene $1 \mathrm{~s}(0.254 \mathrm{mmol})$ and $42.6 \mathrm{mg} \mathrm{H}_{2} \mathrm{O} .{ }^{1} \mathrm{H}$ NMR spectroscopy (400 $\mathrm{MHz}$, $\mathrm{CH}_{2} \mathrm{Cl}_{2}$ ) revealed complete consumption of $1 \mathrm{~s}$. Solvent was then removed in vacuo to yield $40.6 \mathrm{mg}$ of $2 \mathrm{~s}$ as a colorless oil $(0.251 \mathrm{mmol}, 95 \%)$. NMR data obtained are consistent with the literature. ${ }^{20}{ }^{1} \mathrm{H}$ NMR $\left(500 \mathrm{MHz}, \mathrm{CH}_{2} \mathrm{Cl}_{2}\right): \delta 7.28-7.21(\mathrm{~m}, 2 \mathrm{H}), 7.19-7.11(\mathrm{~m}, 2 \mathrm{H}), 2.63-2.57(\mathrm{~m}, 2 \mathrm{H}), 1.56-1.50(\mathrm{~m}, 2 \mathrm{H})$, 0.95 (s, 9H); ${ }^{13} \mathrm{C}$ NMR $\left(125 \mathrm{MHz}, \mathrm{CH}_{2} \mathrm{Cl}_{2}\right): \delta 143.9,128.4,128.4,125.6,46.6,31.4,30.7,29.5$.

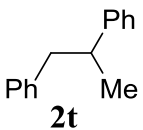

1,2-Diphenylpropane 2t. The general procedure was followed using $59.0 \mathrm{mg}$ of tetrahydroxydiboron $(0.66 \mathrm{mmol}), 57.0 \mathrm{mg}$ of $5 \% \mathrm{Pd} / \mathrm{C}(0.030 \mathrm{mmol}), 2 \mathrm{~mL}$ of DCM, $117.1 \mathrm{mg}$ of $\alpha$-methylstilbene $1 \mathrm{t}(0.60$ mmol) and $50 \mu \mathrm{L}$ of $\mathrm{H}_{2} \mathrm{O} .{ }^{1} \mathrm{H}$ NMR spectroscopy $\left(400 \mathrm{MHz}, \mathrm{CH}_{2} \mathrm{Cl}_{2}\right.$ ) revealed complete consumption of 1t. Solvent was then removed in vacuo to yield $117.8 \mathrm{mg}$ of $\mathbf{2 t}$ as a colorless oil (0.594 mmol, 99\%). NMR data obtained are consistent with the literature. ${ }^{21}{ }^{1} \mathrm{H} \mathrm{NMR}\left(400 \mathrm{MHz}, \mathrm{CDCl}_{3}\right): \delta 7.31-7.17(\mathrm{~m}, 8 \mathrm{H})$, 7.13-7.08 (m, 2H), 3.04-2.91 (m, 2H), $2.79(\mathrm{dd}, J=8.0 \mathrm{~Hz}, 1 \mathrm{H}), 1.26(\mathrm{~d}, J=6.9 \mathrm{~Hz}, 3 \mathrm{H}) ;{ }^{13} \mathrm{C} \mathrm{NMR}$ $\left(100 \mathrm{MHz}, \mathrm{CDCl}_{3}\right): \delta 147.1,140.9,129.3,128.4,128.2,127.2,126.1,126.0,45.2,42.0,21.3$.

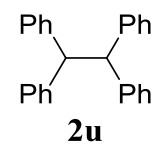

1,1,2,2-Tetraphenylethane $\mathbf{2 u}$. The general procedure was followed using $59.2 \mathrm{mg}$ of tetrahydroxydiboron $(0.66 \mathrm{mmol}), 31.0 \mathrm{mg}$ of $10 \% \mathrm{Pd} / \mathrm{C}(0.030 \mathrm{mmol}), 2 \mathrm{~mL}$ of DCM, $198 \mathrm{mg}$ of tetraphenylethylene $1 \mathbf{u}(0.60 \mathrm{mmol})$ and $52.9 \mathrm{mg}$ of $\mathrm{H}_{2} \mathrm{O}$. The reaction was stopped after 5 hours to give a ${ }^{1} \mathrm{H}$ NMR yield of $74 \%$. After 18 hours, ${ }^{1} \mathrm{H}$ NMR spectroscopy (400 $\mathrm{MHz}, \mathrm{CH}_{2} \mathrm{Cl}_{2}$ ) revealed $88 \%$ consumption of $\mathbf{1 u}$ and an $88 \%$ NMR yield of $\mathbf{2 u}$. NMR data obtained are consistent with the literature. ${ }^{19}$ ${ }^{1} \mathrm{H}$ NMR (400 MHz, $\left.\mathrm{CD}_{2} \mathrm{Cl}_{2}\right): \delta$ 7.25-7.19 (m, 8H), 7.19-7.13 (m, 8H), 7.09-7.03 (m, 4H), $4.82(\mathrm{~s}, 2 \mathrm{H})$; ${ }^{13} \mathrm{C} \mathrm{NMR}\left(100 \mathrm{MHz}, \mathrm{CD}_{2} \mathrm{Cl}_{2}\right): \delta 143.5,131.4,128.5,128.2,127.7,126.4,125.9,56.4$.

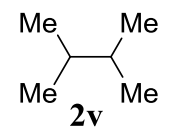

1,1,2,2-Tetramethylethane $\mathbf{2 v}$. The general procedure was followed using $60.1 \mathrm{mg}$ of tetrahydroxydiboron $(0.66 \mathrm{mmol}), 24.7 \mathrm{mg}$ of $10 \% \mathrm{Pd} / \mathrm{C}(0.030 \mathrm{mmol}), 2 \mathrm{~mL}$ of DCM, $52.2 \mathrm{mg}$ of tetramethylethylene $\mathbf{1 v}(0.62 \mathrm{mmol})$ and $52.9 \mathrm{mg}$ of $\mathrm{H}_{2} \mathrm{O} .{ }^{1} \mathrm{H}$ NMR spectroscopy $\left(400 \mathrm{MHz}, \mathrm{CH}_{2} \mathrm{Cl}_{2}\right)$ revealed complete consumption of $\mathbf{1 v}$ and a $99 \%$ NMR yield of $\mathbf{2 v}$. NMR data obtained are consistent 
with the literature. ${ }^{8}{ }^{1} \mathrm{H}$ NMR $\left(400 \mathrm{MHz}, \mathrm{CH}_{2} \mathrm{Cl}_{2}\right): \delta 1.45-1.31(\mathrm{~m}, 2 \mathrm{H}), 0.83(\mathrm{~d}, J=6.5 \mathrm{~Hz}, 12 \mathrm{H}) ;{ }^{13} \mathrm{C}$ NMR (100 MHz, $\left.\mathrm{CH}_{2} \mathrm{Cl}_{2}\right): \delta 33.9,19.4$.

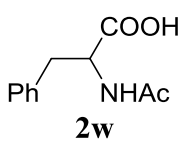

Acetylphenylalanine 2w. The general procedure was followed using $60.5 \mathrm{mg}$ tetrahydroxy diboron $(0.67$ $\mathrm{mmol}), 31.0 \mathrm{mg}$ of $10 \% \mathrm{Pd} / \mathrm{C}(0.030 \mathrm{mmol}), 2 \mathrm{~mL}$ of DCM, $120 \mathrm{mg}$ of $\alpha$-acetamidocinnamic acid $1 \mathbf{w}$ (0.60 mmol) and $50 \mu \mathrm{L}$ of $\mathrm{H}_{2} \mathrm{O} .{ }^{1} \mathrm{H}$ NMR spectroscopy $\left(400 \mathrm{MHz}, \mathrm{CH}_{3} \mathrm{CN}\right.$ ) revealed $96 \%$ consumption of $\mathbf{1 w}$ and a $88 \%$ NMR yield of $\mathbf{2 w}$. NMR data obtained are in good agreement with the literature obtained in $\mathrm{CD}_{3} \mathrm{OD} .{ }^{22,23}{ }^{1} \mathrm{H}$ NMR $(400 \mathrm{MHz}, \mathrm{MeCN}): \delta 7.31-7.16(\mathrm{~m}, 5 \mathrm{H}), 6.77$ (br s, $\left.1 \mathrm{H}\right), 4.57(\mathrm{t}, J=$ $8.2 \mathrm{~Hz}, 1 \mathrm{H}), 3.12(\mathrm{dd}, J=14.0,5.3 \mathrm{~Hz}, 1 \mathrm{H}), 2.91(\mathrm{dd}, J=13.9,8.4 \mathrm{~Hz}, 1 \mathrm{H}), 1.80(\mathrm{~s}, 3 \mathrm{H}) * ;{ }^{13} \mathrm{C}$ NMR (100 MHz, MeCN): $\delta 173.2,171.5,138.0,130.1,129.2,127.6,54.6,37.7,22.6$. *Due to H(PRESAT) of $\mathrm{MeCN}$, the $\mathrm{CH}_{3}$ signal is slightly suppressed.

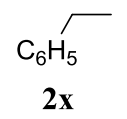

Ethylbenzene 2x. The general procedure was followed using $60.0 \mathrm{mg}$ of tetrahydroxydiboron $(0.66$ $\mathrm{mmol}), 32.0 \mathrm{mg}$ of $10 \% \mathrm{Pd} / \mathrm{C}(0.030 \mathrm{mmol}), 2 \mathrm{~mL}$ of DCM, $60.3 \mathrm{mg}$ of styrene $1 \mathbf{x}(0.58 \mathrm{mmol})$ and 56.9 mg of $\mathrm{H}_{2} \mathrm{O}$. ${ }^{1} \mathrm{H}$ NMR spectroscopy $\left(400 \mathrm{MHz}, \mathrm{CH}_{2} \mathrm{Cl}_{2}\right.$ ) revealed complete consumption of $\mathbf{1 x}$. Solvent was then removed in vacuo to yield $59.1 \mathrm{mg}$ of $\mathbf{2 x}$ as a colorless oil $(0.558 \mathrm{mmol}, 96 \%)$. NMR data obtained are consistent with the literature. ${ }^{8}{ }^{1} \mathrm{H} \mathrm{NMR}\left(400 \mathrm{MHz}, \mathrm{CDCl}_{3}\right): \delta$ 7.33-7.26 (m, 2H), 7.22-7.14 $(\mathrm{m}, 3 \mathrm{H}), 2.67(\mathrm{q}, J=7.6 \mathrm{~Hz}, 2 \mathrm{H}), 1.26(\mathrm{t}, J=7.6 \mathrm{~Hz}, 3 \mathrm{H}) ;{ }^{13} \mathrm{C} \mathrm{NMR}\left(100 \mathrm{MHz}, \mathrm{CDCl}_{3}\right): \delta 144.4,128.4$, 128.0, 125.7, 29.0, 15.8.

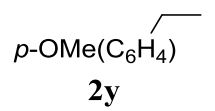

4-Ethylanisole $\mathbf{2 y}$. The general procedure was followed using $60.2 \mathrm{mg}$ of tetrahydroxydiboron $(0.66$ $\mathrm{mmol}), 32.0 \mathrm{mg}$ of $10 \% \mathrm{Pd} / \mathrm{C}(0.030 \mathrm{mmol}), 2 \mathrm{~mL}$ of DCM, $83.2 \mathrm{mg}$ of 4-methoxystyrene $\mathbf{1 y}(0.62$ $\mathrm{mmol}$ ) and $54.6 \mathrm{mg}$ of $\mathrm{H}_{2} \mathrm{O} .{ }^{1} \mathrm{H}$ NMR spectroscopy (400 $\mathrm{MHz}, \mathrm{CH}_{2} \mathrm{Cl}_{2}$ ) revealed complete consumption of $\mathbf{1 y}$. Solvent was then removed in vacuo to yield $81.4 \mathrm{mg}$ of $\mathbf{2 y}$ as a colorless oil $(0.595 \mathrm{mmol}, 96 \%)$. NMR data obtained are consistent with the literature. ${ }^{24}{ }^{1} \mathrm{H}$ NMR $\left(400 \mathrm{MHz}, \mathrm{CH}_{2} \mathrm{Cl}_{2}\right): \delta 7.18(\mathrm{~d}, J=8.6$ $\mathrm{Hz}, 2 \mathrm{H}), 6.90(\mathrm{~d}, J=8.6 \mathrm{~Hz}, 2 \mathrm{H}), 3.84(\mathrm{~s}, 3 \mathrm{H}), 2.66(\mathrm{q}, J=7.6 \mathrm{~Hz}, 2 \mathrm{H}), 1.28(\mathrm{t}, J=7.6 \mathrm{~Hz}, 2 \mathrm{H}) ;{ }^{13} \mathrm{C}$ NMR (100 MHz, CDCl3): $\delta 157.6,136.4,128.7,113.7,55.3,28.0,15.9$.

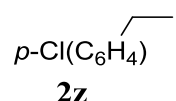

4-Chloro(ethylbenzene) 2z. The general procedure was followed using $56.0 \mathrm{mg}$ of tetrahydroxydiboron (0.62 mmol), $31.8 \mathrm{mg}$ of $10 \% \mathrm{Pd} / \mathrm{C}(0.030 \mathrm{mmol}), 2 \mathrm{~mL}$ of DCM, $83.7 \mathrm{mg}$ of 4-chlorostyrene $\mathbf{1 z}(0.60$ mmol) and $57.6 \mathrm{mg}$ of $\mathrm{H}_{2} \mathrm{O} .{ }^{1} \mathrm{H}$ NMR spectroscopy (400 $\mathrm{MHz}, \mathrm{CH}_{2} \mathrm{Cl}_{2}$ ) revealed complete consumption of $\mathbf{1 z}$. Solvent was then removed in vacuo to yield $80.7 \mathrm{mg}$ of $\mathbf{2 z}$ as a colorless oil $(0.576 \mathrm{mmol}, 96 \%)$. NMR data obtained are consistent with the literature. ${ }^{25}{ }^{1} \mathrm{H}$ NMR $\left(400 \mathrm{MHz}, \mathrm{CDCl}_{3}\right): \delta 7.27(\mathrm{~d}, J=8.4$ 
$\mathrm{Hz}, 2 \mathrm{H}), 7.14(\mathrm{~d}, J=8.4 \mathrm{~Hz}, 2 \mathrm{H}), 2.63(\mathrm{q}, J=7.6 \mathrm{~Hz}, 2 \mathrm{H}), 1.23(\mathrm{t}, J=7.6 \mathrm{~Hz}, 2 \mathrm{H}) ;{ }^{13} \mathrm{C} \mathrm{NMR}(100 \mathrm{MHz}$, $\left.\mathrm{CDCl}_{3}\right): \delta 142.8,131.4,129.3,128.5,28.4,15.7$.

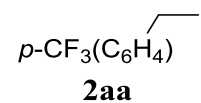

4-Trifluoromethyl(ethylbenzene) 2aa. The general procedure was followed using $60.1 \mathrm{mg}$ of tetrahydroxydiboron $(0.66 \mathrm{mmol}), 32.0 \mathrm{mg}$ of $10 \% \mathrm{Pd} / \mathrm{C}(0.031 \mathrm{mmol}), 2 \mathrm{~mL}$ of DCM, $103.0 \mathrm{mg}$ of $4-$ trifluoromethylstyrene 1aa $(0.60 \mathrm{mmol})$ and $55.2 \mathrm{mg}$ of $\mathrm{H}_{2} \mathrm{O} .{ }^{1} \mathrm{H}$ NMR spectroscopy $\left(400 \mathrm{MHz}, \mathrm{CH}_{2} \mathrm{Cl}_{2}\right)$ revealed complete consumption of 1aa. Solvent was then removed in vacuo to yield $97.4 \mathrm{mg}$ of $\mathbf{2 a a}$ as a colorless oil $(0.560 \mathrm{mmol}, 93 \%)$. NMR data obtained are in general agreement with the literature. ${ }^{26}{ }^{1} \mathrm{H}$ NMR (400 MHz, CDCl3): $\delta 7.55(\mathrm{~d}, J=8.1 \mathrm{~Hz}, 2 \mathrm{H}), 7.31(\mathrm{~d}, J=8.0 \mathrm{~Hz}, 2 \mathrm{H}), 2.72(\mathrm{q}, J=7.6 \mathrm{~Hz}, 2 \mathrm{H})$, $1.27(\mathrm{t}, J=7.6 \mathrm{~Hz}, 2 \mathrm{H}) ;{ }^{13} \mathrm{C} \mathrm{NMR}(100 \mathrm{MHz}, \mathrm{CDCl} 3): \delta 148.4,128.3,125.4(\mathrm{q}, J=3.8), 124.1(\mathrm{q}, J=$ 239.9), 28.9, 15.4 .

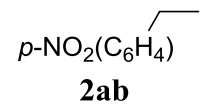

4-Ethyl(nitrobenzene) 2ab. The general procedure was followed using $59.2 \mathrm{mg}$ of tetrahydroxydiboron (0.66 mmol), $29.8 \mathrm{mg}$ of $10 \% \mathrm{Pd} / \mathrm{C}(0.030 \mathrm{mmol}), 2 \mathrm{~mL}$ of DCM, $89.3 \mathrm{mg}$ of 4-nitrostyrene 1 ab $(0.60$ mmol) and $49.0 \mathrm{mg}$ of $\mathrm{H}_{2} \mathrm{O}$. ${ }^{1} \mathrm{H}$ NMR spectroscopy (400 $\mathrm{MHz}, \mathrm{CH}_{2} \mathrm{Cl}_{2}$ ) revealed $55 \%$ consumption of 1ab and a 38\% NMR yield of 2ab. ${ }^{1} \mathrm{H}$ NMR (400 MHz, $\left.\mathrm{CH}_{2} \mathrm{Cl}_{2}\right): \delta 8.11(\mathrm{~d}, J=8.7 \mathrm{~Hz}, 2 \mathrm{H}), 7.32(\mathrm{~d}, J=$ $8.7 \mathrm{~Hz}, 2 \mathrm{H}), 2.74(\mathrm{q}, J=7.6 \mathrm{~Hz}, 2 \mathrm{H}), 1.26(\mathrm{t}, J=7.6 \mathrm{~Hz}, 3 \mathrm{H}) ;{ }^{13} \mathrm{C} \mathrm{NMR}\left(100 \mathrm{MHz}, \mathrm{CH}_{2} \mathrm{Cl}_{2}\right): \delta 152.1$, $146.2,128.7,123.6,28.9,15.1$. By comparison to literature, the remaining inseparable product is 4ethylaniline $(17 \%)$.

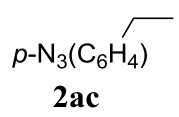

1-Azido-4-ethylbenzene 2ac. The general procedure was followed using $60.1 \mathrm{mg}$ of tetrahydroxydiboron (0.67 mmol), $30.1 \mathrm{mg}$ of $10 \% \mathrm{Pd} / \mathrm{C}(0.030 \mathrm{mmol}), 2 \mathrm{~mL}$ of DCM, $87.3 \mathrm{mg}$ 4-azidostyrene 1ac $(0.60$ mmol) and $53.0 \mathrm{mg}$ of $\mathrm{H}_{2} \mathrm{O}$. ${ }^{1} \mathrm{H}$ NMR spectroscopy $\left(400 \mathrm{MHz}, \mathrm{CH}_{2} \mathrm{Cl}_{2}\right.$ ) revealed $77 \%$ consumption of 1ac and a 6\% NMR yield of 2ac. ${ }^{27} \mathrm{H}$ NMR $\left(400 \mathrm{MHz}, \mathrm{CH}_{2} \mathrm{Cl}_{2}\right): \delta 7.21(\mathrm{~d}, J=8.3 \mathrm{~Hz}, 2 \mathrm{H}), 6.99(\mathrm{~d}, J=$ $8.5 \mathrm{~Hz}, 2 \mathrm{H}), 2.66(\mathrm{q}, J=7.6 \mathrm{~Hz}, 2 \mathrm{H}), 1.26(\mathrm{t}, J=7.6 \mathrm{~Hz}, 3 \mathrm{H}) ;{ }^{13} \mathrm{C} \mathrm{NMR}\left(100 \mathrm{MHz}, \mathrm{CH}_{2} \mathrm{Cl}_{2}\right): \delta 141.1$, $129.2,128.7,128.4,119.0,28.3,15.7$. By comparison to literature, the remaining inseparable products are 4-aminostyrene (33\%), and 4-ethylaniline (35\%).

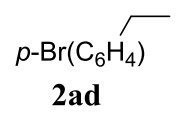

1-Bromo-4-ethylbenzene 2ad. The general procedure was followed using $60.1 \mathrm{mg}$ of tetrahydroxydiboron $(0.67 \mathrm{mmol}), 31.6 \mathrm{mg}$ of $10 \% \mathrm{Pd} / \mathrm{C}(0.030 \mathrm{mmol}), 2 \mathrm{~mL}$ of DCM, $107.2 \mathrm{mg}$ of 4bromostyrene $1 \mathrm{ad}(0.59 \mathrm{mmol})$ and $54.4 \mathrm{mg}$ of $\mathrm{H}_{2} \mathrm{O} .{ }^{1} \mathrm{H}$ NMR spectroscopy $\left(400 \mathrm{MHz}, \mathrm{CH}_{2} \mathrm{Cl}_{2}\right)$ revealed $82 \%$ consumption of $\mathbf{1 a d}$ and a $32 \%$ NMR yield of $\mathbf{2 a d} .{ }^{28} \mathrm{NMR}$ data obtained was in general agreement with the literature. ${ }^{1} \mathrm{H}$ NMR $\left(400 \mathrm{MHz}, \mathrm{CD}_{3} \mathrm{CN}\right): \delta 7.40-7.20(\mathrm{~m}, 2 \mathrm{H}), 7.23-7.10(\mathrm{~m}, 2 \mathrm{H}), 2.63(\mathrm{q}, J=$ $7.6 \mathrm{~Hz}, 2 \mathrm{H}), 1.24$ (t, $J=7.6 \mathrm{~Hz}, 3 \mathrm{H}) ;{ }^{13} \mathrm{C} \mathrm{NMR}\left(100 \mathrm{MHz}, \mathrm{CD}_{3} \mathrm{CN}\right): \delta 143.3,132.7,129.5,127.5,127.3$, $124.3,29.4$, 14.2. By comparison to literature, the remaining inseparable product is ethylbenzene (5\%). 


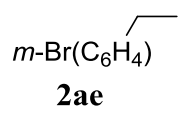

1-Bromo-3-ethylbenzene 2ae. The general procedure was followed using $60.1 \mathrm{mg}$ of tetrahydroxydiboron $(0.67 \mathrm{mmol}), 32.0 \mathrm{mg}$ of $10 \% \mathrm{Pd} / \mathrm{C}(0.030 \mathrm{mmol}), 2 \mathrm{~mL}$ of DCM, $109 \mathrm{mg}$ of 3bromostyrene 1ae $(0.60 \mathrm{mmol})$ and $49.7 \mathrm{mg}$ of $\mathrm{H}_{2} \mathrm{O}$. ${ }^{1} \mathrm{H}$ NMR spectroscopy $\left(400 \mathrm{MHz}, \mathrm{CH}_{2} \mathrm{Cl}_{2}\right)$ revealed $66 \%$ consumption of 1ae and a 51\% NMR yield of 2ae. NMR data obtained are in general agreement with the literature. ${ }^{29}{ }^{1} \mathrm{H}$ NMR $\left(400 \mathrm{MHz}, \mathrm{CDCl}_{3}\right): \delta 7.40-7.20(\mathrm{~m}, 2 \mathrm{H}), 7.23-7.10(\mathrm{~m}, 2 \mathrm{H}), 2.63(\mathrm{q}, J=$ $7.6 \mathrm{~Hz}, 2 \mathrm{H}), 1.24(\mathrm{t}, J=7.6 \mathrm{~Hz}, 3 \mathrm{H}) ;{ }^{13} \mathrm{C} \mathrm{NMR}\left(100 \mathrm{MHz}, \mathrm{CDCl}_{3}\right): \delta 143.3,132.7,129.5,127.5,127.3$, 124.3, 29.4, 14.2. By comparison to literature, the remaining inseparable product is ethylbenzene (9\%).

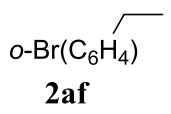

1-Bromo-2-ethylbenzene 2af. The general procedure was followed using $60.1 \mathrm{mg}$ of tetrahydroxydiboron $(0.67 \mathrm{mmol}), 32.0 \mathrm{mg}$ of $10 \% \mathrm{Pd} / \mathrm{C}(0.030 \mathrm{mmol}), 2 \mathrm{~mL}$ of DCM, $109 \mathrm{mg}$ of 2bromostyrene 1af $(0.60 \mathrm{mmol})$ and $49.7 \mathrm{mg}$ of $\mathrm{H}_{2} \mathrm{O} .{ }^{1} \mathrm{H}$ NMR spectroscopy $\left(400 \mathrm{MHz}, \mathrm{CH}_{2} \mathrm{Cl}_{2}\right)$ revealed $84 \%$ consumption of 1 af and a $25 \%$ NMR yield of 2 af. ${ }^{1} \mathrm{H}$ NMR $\left(400 \mathrm{MHz}, \mathrm{CDCl}_{3}\right): \delta 7.57-7.55(\mathrm{~m}$, $1 \mathrm{H}), 7.26-7.23(\mathrm{~m}, 2 \mathrm{H}), 7.14-7.09(\mathrm{~m}, 1 \mathrm{H}), 2.78(\mathrm{q}, J=7.5 \mathrm{~Hz}, 2 \mathrm{H}), 1.25(\mathrm{t}, J=6.8 \mathrm{~Hz}, 3 \mathrm{H}) ;{ }^{13} \mathrm{C} \mathrm{NMR}$ $\left(100 \mathrm{MHz}, \mathrm{CDCl}_{3}\right): \delta 143.3,132.7,129.5,127.5,127.3,124.3,29.4,14.2$. By comparison to literature, the remaining inseparable product is ethylbenzene (10\%).

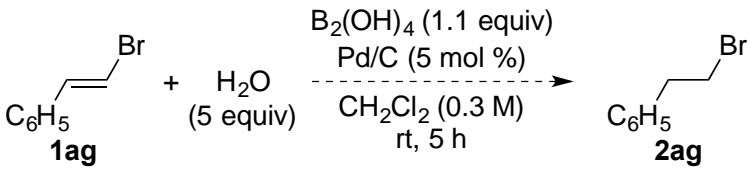

Attempted hydrogenation of $\boldsymbol{\beta}$-bromostyrene 1ag. The general procedure was followed using $59.7 \mathrm{mg}$ of tetrahydroxydiboron ( $0.66 \mathrm{mmol}), 27.9 \mathrm{mg}$ of $10 \% \mathrm{Pd} / \mathrm{C}(0.028 \mathrm{mmol}), 2 \mathrm{~mL}$ of DCM, $109.5 \mathrm{mg}$ of 2bromostyrene $1 \mathbf{a g}(0.60 \mathrm{mmol})$ and $49.8 \mathrm{mg}$ of $\mathrm{H}_{2} \mathrm{O}$. The reaction was stopped after 5 hours and $\mathbf{2 a g}$ was not detected. ${ }^{1} \mathrm{H}$ NMR spectroscopy $\left(400 \mathrm{MHz}, \mathrm{CH}_{2} \mathrm{Cl}_{2}\right.$ ) revealed $66 \%$ consumption of $\mathbf{1 a g}$ and an apparent mixture of $\beta$-bromostyrene (34\%), styrene (3\%), and ethylbenzene (8\%).

\section{Hydrogenation of Alkynes 3a-3c}

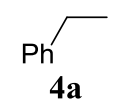

Hydrogenation of phenylacetylene to ethyl benzene 4a. A modified procedure of alkene reduction was employed using $119.6 \mathrm{mg}$ of tetrahydroxydiboron $(1.33 \mathrm{mmol}), 30.1 \mathrm{mg}$ of $10 \% \mathrm{Pd} / \mathrm{C}(0.030 \mathrm{mmol}), 2$ $\mathrm{mL}$ of DCM, $62.3 \mathrm{mg}$ of phenyl acetylene 3a $(0.61 \mathrm{mmol})$ and $98.9 \mu \mathrm{L}$ of $\mathrm{H}_{2} \mathrm{O} .{ }^{1} \mathrm{H}$ NMR spectroscopy (400 MHz, $\mathrm{CH}_{2} \mathrm{Cl}_{2}$ ) revealed complete consumption of 3a. Solvent was then removed in vacuo to yield $61.4 \mathrm{mg}$ of $4 \mathbf{a}$ as a colorless oil $(0.579 \mathrm{mmol}, 95 \%)$. NMR data obtained are consistent with the literature. ${ }^{30} \mathrm{H}$ NMR $\left(400 \mathrm{MHz}, \mathrm{CDCl}_{3}\right): \delta 7.37-7.31(\mathrm{~m}, 2 \mathrm{H}), 7.28-7.21(\mathrm{~m}, 3 \mathrm{H}), 2.71(\mathrm{q}, J=7.6 \mathrm{~Hz}$, 2H), $1.30(\mathrm{t}, J=7.6 \mathrm{~Hz}, 3 \mathrm{H}) ;{ }^{13} \mathrm{C} \mathrm{NMR}\left(100 \mathrm{MHz}, \mathrm{CDCl}_{3}\right): \delta 144.4,128.4,128.0,125.7,29.0,15.8$. 


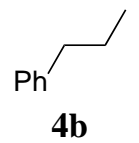

Hydrogenation of 1-phenyl-1-propyne to propyl benzene 4b. A modified procedure of alkene reduction was employed using $120.0 \mathrm{mg}$ of tetrahydroxydiboron $(1.33 \mathrm{mmol}), 29.9 \mathrm{mg}$ of $10 \% \mathrm{Pd} / \mathrm{C}$ (0.030 mmol), $2 \mathrm{~mL}$ of DCM, $69.1 \mathrm{mg}$ of 1-phenyl-1-propyne $3 \mathbf{b}(0.60 \mathrm{mmol})$ and $30 \mu \mathrm{L}$ of $\mathrm{H}_{2} \mathrm{O} .{ }^{1} \mathrm{H}$ NMR spectroscopy (400 MHz, $\mathrm{CH}_{2} \mathrm{Cl}_{2}$ ) revealed complete consumption of $\mathbf{3 b}$. Solvent was then removed in vacuo to yield $68 \mathrm{mg}$ of $\mathbf{4 b}$ as a colorless oil (0.566 mmol, 95\%). NMR data obtained are consistent with the literature. ${ }^{20}{ }^{1} \mathrm{H}$ NMR $\left(400 \mathrm{MHz}, \mathrm{CDCl}_{3}\right): \delta 7.36-7.29(\mathrm{~m}, 2 \mathrm{H}), 7.25-7.19(\mathrm{~m}, 3 \mathrm{H}), 2.64(\mathrm{t}, J=$ $7.5 \mathrm{~Hz}, 2 \mathrm{H}$ ), 1.70 (quintet, $J=7.4 \mathrm{~Hz}, 2 \mathrm{H}), 1.00(\mathrm{t}, J=7.3 \mathrm{~Hz}, 3 \mathrm{H}) ;{ }^{13} \mathrm{C} \mathrm{NMR}\left(100 \mathrm{MHz}, \mathrm{CDCl}_{3}\right): \delta$ $142.8,128.6,128.3,125.7,38.2,24.7,14.0$.

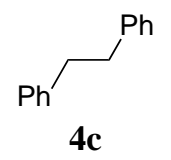

Hydrogenation of diphenyl acetylene to 1,2-diphenylethane 4c. A modified procedure of alkene reduction was employed using $118.8 \mathrm{mg}$ of tetrahydroxydiboron $(1.32 \mathrm{mmol}), 31.0 \mathrm{mg}$ of $10 \% \mathrm{Pd} / \mathrm{C}$ (0.030 mmol), $2 \mathrm{~mL}$ of DCM, $110.1 \mathrm{mg}$ of diphenylacetylene 3a $(0.62 \mathrm{mmol})$ and $30 \mu \mathrm{L}$ of $\mathrm{H}_{2} \mathrm{O} .{ }^{1} \mathrm{H}$ NMR spectroscopy (400 MHz, $\mathrm{CH}_{2} \mathrm{Cl}_{2}$ ) revealed complete consumption of 3c. Solvent was then removed in vacuo to yield $110.2 \mathrm{mg}$ of $\mathbf{4 c}$ as a colorless solid $(0.605 \mathrm{mmol}, 98 \%)$. NMR data obtained are consistent with the literature. ${ }^{19}{ }^{1} \mathrm{H}$ NMR $\left(400 \mathrm{MHz}, \mathrm{CDCl}_{3}\right): \delta$ 7.39-7.46 (m, 4H), 7.36-7.29 (m, 6H), $3.06(\mathrm{~s}, 4 \mathrm{H}) ;{ }^{13} \mathrm{C} \mathrm{NMR}\left(100 \mathrm{MHz}, \mathrm{CDCl}_{3}\right): \delta 141.9,128.6,128.5,126.0,38.1$.

$$
{ }_{\mathrm{Ph}}{ }_{1 \mathbf{r}} \mathrm{Ph}
$$

Semihydrogenation of diphenylacetylene to cis-stilbene 1r. A modified procedure of alkene reduction was employed using $29.6 \mathrm{mg}$ of tetrahydroxydiboron $(0.33 \mathrm{mmol}), 32.0 \mathrm{mg}$ of Lindlar catalyst $(0.015$ $\mathrm{mmol}), 1 \mathrm{~mL}$ of DCM, $53.4 \mathrm{mg}$ of diphenylacetylene $3 \mathrm{c}(0.30 \mathrm{mmol}), 0.10 \mathrm{~mL}$ of triethylamine and 30 $\mu \mathrm{L}$ of $\mathrm{H}_{2} \mathrm{O}$. ${ }^{1} \mathrm{H}$ NMR spectroscopy (400 $\mathrm{MHz}, \mathrm{CH}_{2} \mathrm{Cl}_{2}$ ) revealed $71 \%$ consumption of $\mathbf{3 c}$ and a $63 \% \mathrm{NMR}$ yield of 1r. NMR data obtained are consistent with the literature. ${ }^{11}{ }^{1} \mathrm{H}$ NMR $\left(400 \mathrm{MHz}, \mathrm{CH}_{2} \mathrm{Cl}_{2}\right): \delta 7.30$ $7.19(\mathrm{~m}, 10 \mathrm{H}), 6.61(\mathrm{~s}, 2 \mathrm{H}) ;{ }^{13} \mathrm{C}$ NMR $\left(100 \mathrm{MHz}, \mathrm{CH}_{2} \mathrm{Cl}_{2}\right): \delta 137.2,130.3,128.9,128.2$, 127.2. By comparison to literature, the remaining inseparable products are trans-stilbene (5\%) and bibenzyl (3\%).

\section{E. Attempted Deboronation of Phenethylboronic Acid}

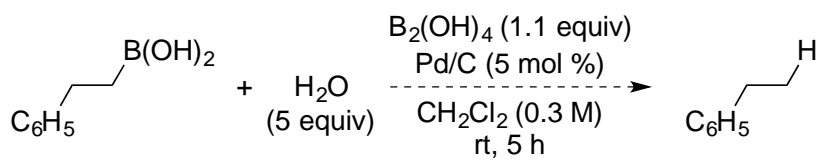

The general procedure was followed using $59.7 \mathrm{mg}$ of tetrahydroxydiboron $(0.66 \mathrm{mmol}), 28.0 \mathrm{mg}$ of $10 \%$ $\mathrm{Pd} / \mathrm{C}(0.028 \mathrm{mmol}), 2 \mathrm{~mL}$ of DCM, $90.5 \mathrm{mg}$ of phenethylboronic acid $(0.60 \mathrm{mmol})$ and $50 \mu \mathrm{L}$ of $\mathrm{H}_{2} \mathrm{O}$. The reaction was allowed to stir overnight and filtered through Celite ${ }^{\circledR}$ to remove any resulting boric acid and unreacted tetrahydroxydiboron. ${ }^{1} \mathrm{H}$ PRESAT and ${ }^{11} \mathrm{~B}$ NMR show only the presence of phenethylboronic acid starting material. ${ }^{31}{ }^{1} \mathrm{H}$ NMR $\left(400 \mathrm{MHz}, \mathrm{CH}_{2} \mathrm{Cl}_{2}\right): \delta 7.38-7.08(\mathrm{~m}, 5 \mathrm{H}), 4.71(\mathrm{~s}$, $1 \mathrm{H}), 2.70(\mathrm{t}, J=8.1,2 \mathrm{H}), 1.13(\mathrm{t}, J=8.1,2 \mathrm{H}) ;{ }^{11} \mathrm{~B} \mathrm{NMR}\left(160 \mathrm{MHz}, \mathrm{CH}_{2} \mathrm{Cl}_{2}\right): \delta 32.4$. 


\section{Palladium Catalyzed Transfer Deuteriation Reactions}

\section{A. General Considerations and Procedure}

Reactions were carried out in an argon purged glove box with $\mathrm{O}_{2}<0.5 \mathrm{ppm}$ and water $<1.5 \mathrm{ppm} . \mathrm{D}_{2} \mathrm{O}$ obtained from Sigma-Aldrich was $99 \%$ isotopically labeled. Evaluation of $\mathrm{CH}_{2} \mathrm{Cl}_{2}$ by Karl Fisher titration revealed 5.4 ppm $\mathrm{H}_{2} \mathrm{O} ; \mathrm{CH}_{2} \mathrm{Cl}_{2}$ was subsequently stored over $3 \AA$ molecular sieves. To a 1 dram vial equipped with a stir bar, $78.0 \mathrm{mg}(0.33 \mathrm{mmols})$ of bis(catecholato)diboron, $15.0 \mathrm{mg}$ of $10 \% \mathrm{Pd} / \mathrm{C}(0.015$ mmols) were added. The vial was then charged with $1 \mathrm{~mL}$ of $\mathrm{CH}_{2} \mathrm{Cl}_{2}$ and $54.0 \mathrm{mg}$ of diphenylacetylene $3 \mathbf{c}(0.30 \mathrm{mmols})$ and $30 \mathrm{mg}$ of $\mathrm{D}_{2} \mathrm{O}$. The vial was capped and stirred for 5 hours. Solvent was removed in vacuo and the material filtered through a silica plug using pentane to remove the catechol boric acid. After removal of pentane, ${ }^{1} \mathrm{H}$ NMR and ${ }^{13} \mathrm{C}$ NMR were obtained using $\mathrm{CD}_{2} \mathrm{Cl}_{2}$ or $\mathrm{CDCl}_{3}$. ${ }^{1} \mathrm{H}$ relaxation times were increased to a minimum of 5 seconds. Procedures using tetradeuteroxydiboron were worked up the same way. The expected triplets were observed in the ${ }^{13} \mathrm{C}$ NMR for the deuterium labeled carbon.

\section{B. Deuteriation of $1 \mathrm{a}$ and $3 \mathrm{c}$}

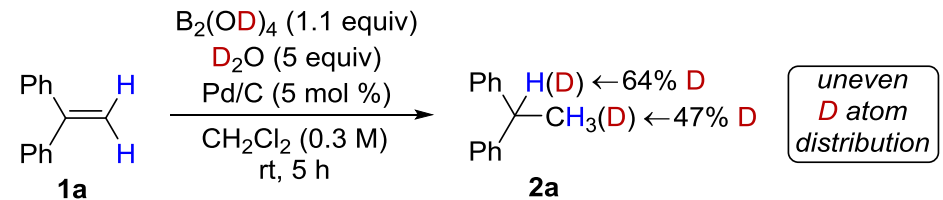

Deuteriation of 1,1-diphenylethylene 1a to 1,1-diphenylethane $2 a$ using $\mathbf{B}_{2}(\mathrm{OD})_{4}$. The general deuteriation procedure was followed using $64 \mathrm{mg}$ of tetradeutoroxydiboron $(0.68 \mathrm{mmol}), 29.3 \mathrm{mg}$ of $10 \%$ $\mathrm{Pd} / \mathrm{C}(0.027 \mathrm{mmol}), 1 \mathrm{~mL}$ of DCM, $101 \mathrm{mg}$ of 1,1-diphenylethylene $1 \mathrm{a}(0.56 \mathrm{mmol})$ and $66 \mathrm{mg}$ of $\mathrm{D}_{2} \mathrm{O}$. ${ }^{1} \mathrm{H}$ NMR $\left(400 \mathrm{MHz}, \mathrm{CDCl}_{3}\right): \delta 7.32-7.16(\mathrm{~m}, 10 \mathrm{H}), 4.17(\mathrm{q}, J=6.4 \mathrm{~Hz}, 0.36 \mathrm{H}), 1.61(\mathrm{t}, J=7.0 \mathrm{~Hz}$, $1.60 \mathrm{H}) ;{ }^{13} \mathrm{C}$ NMR (100 MHz, $\mathrm{CD}_{2} \mathrm{Cl}_{2}$ ): $\delta$ 146.7, 128.5, 127.7, 126.2, $45.0(\mathrm{t}), 21.7(\mathrm{t})$. Deuterium incorporation is $101 \%$ with $64 \%$ and $47 \%$ on the methine and methyl carbons, respectively.

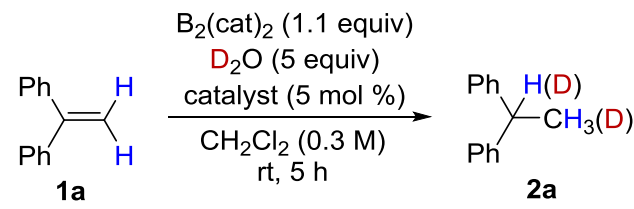

Deuteriation of 1,1-diphenylethylene 1a to 1,1-diphenylethane $2 a$ using $B_{2}(\text { cat })_{2}$. The general deuteriation procedure was followed using $78.5 \mathrm{mg}$ of bis(catecholato) diboron $(0.33 \mathrm{mmol}), 15.0 \mathrm{mg}$ of $10 \% \mathrm{Pd} / \mathrm{C}(0.015 \mathrm{mmol}), 1 \mathrm{~mL}$ of DCM, $54 \mathrm{mg}$ of 1,1-diphenylethylene $1 \mathrm{a}(0.30 \mathrm{mmol})$ and $30 \mu \mathrm{L}$ of $\mathrm{D}_{2} \mathrm{O} .{ }^{1} \mathrm{H}$ NMR $\left(400 \mathrm{MHz}, \mathrm{CD}_{2} \mathrm{Cl}_{2}\right.$ ): $\delta 7.32-7.16(\mathrm{~m}, 10 \mathrm{H}), 4.17$ (q, $\left.J=6.4 \mathrm{~Hz}, 0.43 \mathrm{H}\right), 1.61(\mathrm{t}, J=7.0$ $\mathrm{Hz}, 1.67 \mathrm{H})$. Deuterium incorporation is $95 \%$ with 57 and $44 \%$ on the methine and methyl carbons, respectively. Deuteriation Using $\mathbf{B}_{2}(\mathbf{c a t})_{2}$ by $\mathbf{R h} / \mathbf{C}$ was carried out as above replacing $\mathrm{Pd} / \mathrm{C}$ for $\mathrm{Rh} / \mathrm{C}:{ }^{1} \mathrm{H}$ NMR (400 MHz, $\left.\mathrm{CDCl}_{3}\right): \delta 4.17(\mathrm{q}, J=6.4 \mathrm{~Hz}, 0.50 \mathrm{H}), 1.61(\mathrm{t}, J=7.0 \mathrm{~Hz}, 1.50 \mathrm{H})$. Deuterium incorporation is $100 \%$ with 50 and $50 \%$ on the methine and methyl carbons, respectively. Deuteriation Using $\mathbf{B}_{\mathbf{2}}$ (cat) $)_{\mathbf{2}}$ by $\mathbf{P t} / \mathbf{C}$ was carried out as above replacing $\mathrm{Pd} / \mathrm{C}$ for $\mathrm{Rh} / \mathrm{C}:{ }^{1} \mathrm{H} \mathrm{NMR}\left(400 \mathrm{MHz}, \mathrm{CDCl}_{3}\right): \delta$ $7.32-7.16(\mathrm{~m}, 10 \mathrm{H}), 4.19(\mathrm{q}, J=6.4 \mathrm{~Hz}, 0.36 \mathrm{H}), 1.67(\mathrm{t}, J=7.0 \mathrm{~Hz}, 1.65 \mathrm{H})$. Deuterium incorporation is $99.5 \%$ with 64 and $45 \%$ on the methine and methyl carbons, respectively. 


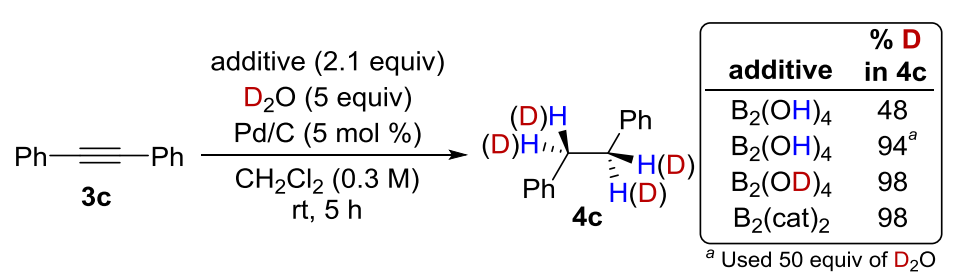

Deuteriation of diphenylacetylene to 1,2-diphenylethane $4 c$ using $\mathbf{B}_{\mathbf{2}}(\mathrm{OH})_{\mathbf{4}}$. The general deuteriation procedure was followed using $32 \mathrm{mg}$ of tetrahydroxydiboron $(0.36 \mathrm{mmol}), 9 \mathrm{mg}$ of $10 \% \mathrm{Pd} / \mathrm{C}(0.008$ $\mathrm{mmol}), 1 \mathrm{~mL}$ of DCM, $30 \mathrm{mg}$ of diphenylacetylene $3 \mathbf{c}(0.17 \mathrm{mmol})$ and $30 \mu \mathrm{L}$ of $\mathrm{D}_{2} \mathrm{O} .{ }^{1} \mathrm{H}$ NMR $(400$ $\left.\mathrm{MHz}, \mathrm{CH}_{2} \mathrm{Cl}_{2}\right): \delta 7.29-7.25(\mathrm{~m}, 4 \mathrm{H}), 7.21-7.16(\mathrm{~m}, 6 \mathrm{H}), 2.92(\mathrm{~m}, 2.10 \mathrm{H})$. Deuterium incorporation is $48 \%$. Deuteriation of $3 c$ using 50 equiv $\mathbf{D}_{2} \mathrm{O}$ was carried out as above using $150 \mu \mathrm{L}$ of $\mathrm{D}_{2} \mathrm{O}:{ }^{1} \mathrm{H}$ NMR $\left(400 \mathrm{MHz}, \mathrm{CD}_{2} \mathrm{Cl}_{2}\right): \delta 7.29-7.25(\mathrm{~m}, 4 \mathrm{H}), 7.21-7.16(\mathrm{~m}, 6 \mathrm{H}), 2.92(\mathrm{~s}, 0.23 \mathrm{H})$. Deuterium incorporation is 94\%. Deuteriation of $\mathbf{3} \mathbf{c}$ using $\mathbf{B}_{\mathbf{2}}(\mathbf{c a t})_{2}$ was carried out according to the general deuteriation procedure using $78.0 \mathrm{mg}$ of bis(catecholato) diboron $(0.33 \mathrm{mmol}), 15.0 \mathrm{mg}$ of $10 \% \mathrm{Pd} / \mathrm{C}(0.015 \mathrm{mmol}), 1 \mathrm{~mL}$ of DCM, $54 \mathrm{mg}$ of diphenylacetylene $3 \mathrm{c}(0.30 \mathrm{mmol})$ and $30 \mu \mathrm{L}$ of $\mathrm{D}_{2} \mathrm{O} .{ }^{1} \mathrm{H}$ NMR $\left(400 \mathrm{MHz}, \mathrm{CD}_{2} \mathrm{Cl}_{2}\right): \delta$ 7.29-7.25 (m, 4H), 7.21-7.16 (m, 6H), $2.92(\mathrm{~s}, 0.12 \mathrm{H}) ;{ }^{13} \mathrm{C}$ NMR (100 MHz, $\left.\mathrm{CD}_{2} \mathrm{Cl}_{2}\right): \delta 142.2,129.0$, 128.8, 126.4, 37.1(t). Deuterium incorporation is $97.5 \%$. Deuteriation of $\mathbf{3 c}$ using $\mathbf{B}_{\mathbf{2}}(\mathbf{O D})_{\mathbf{4}}$ was carried out as above replacing $\mathrm{B}_{2}(\mathrm{OD})_{4}$ for $\mathrm{B}_{2}(\mathrm{cat})_{2}:{ }^{1} \mathrm{H} \mathrm{NMR}\left(400 \mathrm{MHz}, \mathrm{CDCl}_{3}\right): \delta$ 7.29-7.25 (m, 4H), 7.21$7.16(\mathrm{~m}, 6 \mathrm{H}), 2.92(\mathrm{~s}, 0.10 \mathrm{H})$. Deuterium incorporation is $98 \%$.

\section{Kinetic Isotope Effect Experiment; Crossover Experiment; Stereoselectivity of Pd Insertion}

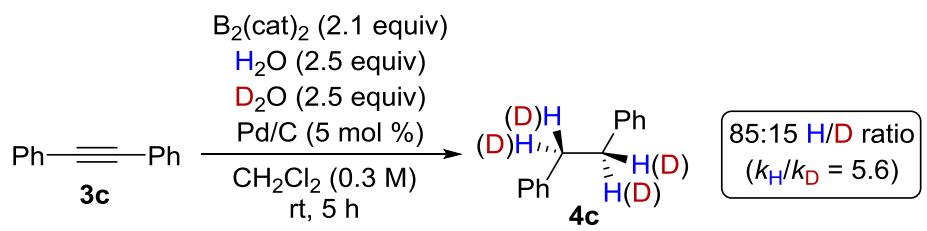

Kinetic isotope effect: competitive hydrogenation/deuteriation of diphenylacetylene 3c. A modified deuteriation procedure was followed using $78.0 \mathrm{mg}$ of bis(catecholato) diboron $(0.33 \mathrm{mmol}), 15.0 \mathrm{mg}$ of $10 \% \mathrm{Pd} / \mathrm{C}(0.015 \mathrm{mmol}), 1 \mathrm{~mL}$ DCM, $54 \mathrm{mg}$ of diphenylacetylene $3 \mathbf{c}(0.30 \mathrm{mmol})$ and $30 \mu \mathrm{L}$ of a 1:1 $\mathrm{H}_{2} \mathrm{O}: \mathrm{D}_{2} \mathrm{O}$ solution. ${ }^{1} \mathrm{H}$ NMR $\left(500 \mathrm{MHz}, \mathrm{CD}_{2} \mathrm{Cl}_{2}\right): \delta 7.29-7.25(\mathrm{~m}, 4 \mathrm{H}), 7.21-7.16(\mathrm{~m}, 6 \mathrm{H}), 2.92(\mathrm{~m}$, $3.39 \mathrm{H}) ;{ }^{13} \mathrm{C}$ NMR $\left(125 \mathrm{MHz}, \mathrm{CD}_{2} \mathrm{Cl}_{2}\right): \delta 142.5,129.0,128.9,126.4,38.4,38.3$ (t). A kinetic isotope effect of 5.55 is observed.

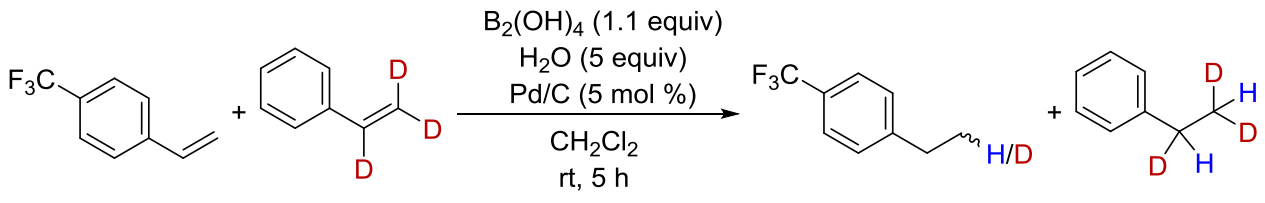

Crossover experiment: Intermolecular proton transfer interrogation via reduction of styrene- $\alpha, \beta, \beta$ d3 and 4-trifluoromethylstyrene: A vial containing $60.1 \mathrm{mg}$ of tetrahydroxydiboron $(0.66 \mathrm{mmol})$ and $30.1 \mathrm{mg}$ of $10 \% \mathrm{Pd} / \mathrm{C}(0.03 \mathrm{mmol})$ was degassed for 15 minutes. After backfilling with argon, $2.0 \mathrm{~mL}$ of dry $\mathrm{CH}_{2} \mathrm{Cl}_{2}$ was added along with $33.2 \mathrm{mg}$ of deuteriated styrene $(0.31 \mathrm{mmol})$ and $40.6 \mathrm{mg}$ of 4 trifluoromethylstyrene $(0.30 \mathrm{mmol})$. Subsequently, $55.0 \mathrm{mg}$ distilled and degassed water was added and stirred at $600 \mathrm{rpm}$. After 5 hours, the reaction was filtered through a Celite ${ }^{\circledR}$ plug and washed with dichloromethane. Minimal solvent was removed in vacuo to minimze product loss. ${ }^{1} \mathrm{H}$ NMR was obtained using $500 \mathrm{MHz}$ in $\mathrm{C}_{6} \mathrm{D}_{6}$ to provide adequate separation of all peaks. It was evident that the terminal 
methyl peak of product 4-ethyl(trifluorobenzene) contained less than the expected number of $\mathrm{H}$ atoms, suggesting deuterium incorporation. 4-ethyl(trifluorobenzene ${ }^{1} \mathrm{H}$ NMR $\left(500 \mathrm{MHz}, \mathrm{C}_{6} \mathrm{D}_{6}\right): \delta 7.39(\mathrm{t}, J=$ $8.0 \mathrm{~Hz}, 2.00 \mathrm{H}), 6.84(\mathrm{t}, J=8.1 \mathrm{~Hz}, 2.00 \mathrm{H}), 2.29(\mathrm{t}, J=7.5 \mathrm{~Hz}, 2.03 \mathrm{H}), 0.97(\mathrm{t}, J=7.6 \mathrm{~Hz}, 2.43 \mathrm{H})$.

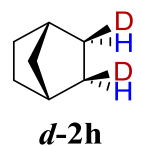

Synthesis of exo-exo-2,3-dideuteronorbornane: The general deuteriation procedure was followed using $31 \mathrm{mg}$ of tetradeuteroxydiboron $(0.33 \mathrm{mmol}), 15.0 \mathrm{mg}$ of $10 \% \mathrm{Pd} / \mathrm{C}(0.015 \mathrm{mmol}), 1 \mathrm{~mL}$ of $\mathrm{CDCl}_{3}, 27$ $\mathrm{mg}$ of norbornene $\mathbf{1 h}(0.30 \mathrm{mmol})$ and $30 \mu \mathrm{L}$ of $\mathrm{D}_{2} \mathrm{O} .{ }^{1} \mathrm{H} \mathrm{NMR}\left(500 \mathrm{MHz}, \mathrm{CDCl}_{3}\right): \delta 2.20(\mathrm{~s}, 2 \mathrm{H}), 1.51-$ $1.44(\mathrm{~m}, 2.1 \mathrm{H}), 1.21-1.13(\mathrm{~m}, 6 \mathrm{H}) ;{ }^{13} \mathrm{C}$ NMR $\left(125 \mathrm{MHz}, \mathrm{CDCl}_{3}\right): \delta 41.0,38.9,32.3,31.9(\mathrm{t})$. A $95 \%$ deuterium incorporation is observed with only exo-deuteriation, suggesting a syn addition by comparison with the literature spectral data. ${ }^{32}$ 


\section{References}

(1) Gresser, M. J.; Keller, P. A.; Wales, S. M. Tetrahedron Lett. 2009, 50 (34), 4899.

(2) Kurita, T.; Aoki, F.; Mizumoto, T.; Maejima, T.; Esaki, H.; Maegawa, T.; Monguchi, Y.; Sajiki, H. Chem. - A Eur. J. 2008, 14 (11), 3371.

(3) Buchner, K. M.; Clark, T. B.; Loy, J. M. N.; Nguyen, T. X.; Woerpel, K. A. Org. Lett. 2009, 11 (10), 2173.

(4) Ikawa, T.; Sajiki, H.; Hirota, K. Tetrahedron 2004, 60 (29), 6189.

(5) Andrews, P.; Latham, C. M.; Magre, M.; Willcox, D.; Woodward, S. Chem. Commun. 2013, 49 (15), 1488.

(6) Baber, R. A.; Norman, N. C.; Orpen, a. G.; Rossi, J. New J. Chem. 2003, 27 (5), 773.

(7) Schoenebeck, F.; Murphy, J. A.; Zhou, S.; Uenoyama, Y.; Miclo, Y.; Tuttle, T. J. Am. Chem. Soc. 2007, 129 (44), 13368.

(8) Sunada, Y.; Tsutsumi, H.; Shigeta, K.; Yoshida, R.; Hashimoto, T.; Nagashima, H. Dalt. Trans. 2013, 42 (48), 16687.

(9) Jones, I. C.; Sharman, G. J.; Pidgeon, J. Magn. Reson. Chem. 2005, 43 (6), 497.

(10) Connolly, T.; Wang, Z.; Walker, M. A.; McDonald, I. M.; Peese, K. M. Org. Lett. 2014, 16 (17), 4444.

(11) Poldy, J.; Peakall, R.; Barrow, R. a. Tetrahedron Lett. 2008, 49 (15), 2446.

(12) Kechaou-Perrot, M.; Vendier, L.; Bastin, S.; Sotiropoulos, J.-M.; Miqueu, K.; MenéndezRodríguez, L.; Crochet, P.; Cadierno, V.; Igau, A. Organometallics 2014, 33 (22), 6294.

(13) Fulmer, G. R.; Miller, A. J. M.; Sherden, N. H.; Gottlieb, H. E.; Nudelman, A.; Stoltz, B. M.; Bercaw, J. E.; Goldberg, K. I. Organometallics 2010, 29 (9), 2176.

(14) Liniger, M.; Estermann, K.; Altmann, K. J. Org. Chem. 2013, 78 (21), 11066.

(15) Iwasaki, K.; Wan, K. K.; Oppedisano, A.; Crossley, S. W. M.; Shenvi, R. A. J. Am. Chem. Soc. 2014, $136(4), 1300$.

(16) Amatore, M.; Gosmini, C.; Périchon, J. J. Org. Chem. 2006, 71 (16), 6130.

(17) Szostak, M.; Spain, M.; Procter, D. J. Org. Lett. 2012, 14 (3), 840.

(18) Yamada, K.; Fujita, H.; Kunishima, M. Org. Lett. 2012, 14 (19), 5026.

(19) Sato, K.; Inoue, Y.; Mori, T.; Sakaue, A.; Tarui, A.; Omote, M.; Kumadaki, I.; Ando, A. Org. Lett. 2014, 16 (14), 3756.

(20) Le Bailly, B. a. F.; Greenhalgh, M. D.; Thomas, S. P. Chem. Commun. 2012, 48 (10), 1580.

(21) Metallinos, C.; Zaifman, J.; Van Belle, L.; Dodge, L.; Pilkington, M. Organometallics 2009, 28 (15), 4534.

(22) Koshti, N.; Naik, S.; Parab, B. Indian J. Chem. 2005, 44 (December), 2555.

(23) Boaz, N. W.; Mackenzie, E. B.; Debenham, S. D.; Large, S. E.; Ponasik, J. a. J. Org. Chem. 2005, $70(5), 1872$.

(24) Maegawa, T.; Takahashi, T.; Yoshimura, M.; Suzuka, H.; Monguchi, Y.; Sajiki, H. Adv. Synth. Catal. 2009, 351 (13), 2091.

(25) Sloan, M. E.; Staubitz, A.; Lee, K.; Manners, I. Eur. J. Org. Chem. 2011, 2011 (4), 672.

(26) Hilborn, J. W.; MacKnight, E.; Pincock, J. A.; Wedge, P. J. ChemInform 2010, 25 (34), 3337.

(27) Hu, M.; Li, J.; Q. Yao, S. Org. Lett. 2008, 10 (24), 5529.

(28) Gieshoff, T. N.; Villa, M.; Welther, A.; Plois, M.; Chakraborty, U.; Wolf, R.; Jacobi von Wangelin, A. Green Chem. 2015, 17 (3), 1408.

(29) Lunazzi, L.; Mazzanti, A.; Muñoz Álvarez, A. J. Org. Chem. 2000, 65 (10), 3200.

(30) Ratheesh Kumar, V. K.; Gopidas, K. R. Tetrahedron Lett. 2011, 52 (24), 3102.

(31) Pasumansky, L.; Haddenham, D.; Clary, J. W.; Fisher, G. B.; Goralski, C. T.; Singaram, B. J. Org. Chem. 2008, 73(5), 1898.

(32) Liu, Z.; Yamamichi, H.; Madrahimov, S.; Hartwig, J. J. Am. Chem. Soc. 2011, 133(8), 2772. 
VI. NMR and IR Spectra

A. ${ }^{1} \mathrm{H},{ }^{13} \mathrm{C},{ }^{11} \mathrm{~B}$ NMR of Synthesized 1d, 1o, 1p, 1s, 1ac, $\mathrm{B}_{2}(\mathrm{OD})_{4}$

1-benzyloxypent-4-ene - PROTON
$\mathrm{CDCl} 3$

1d

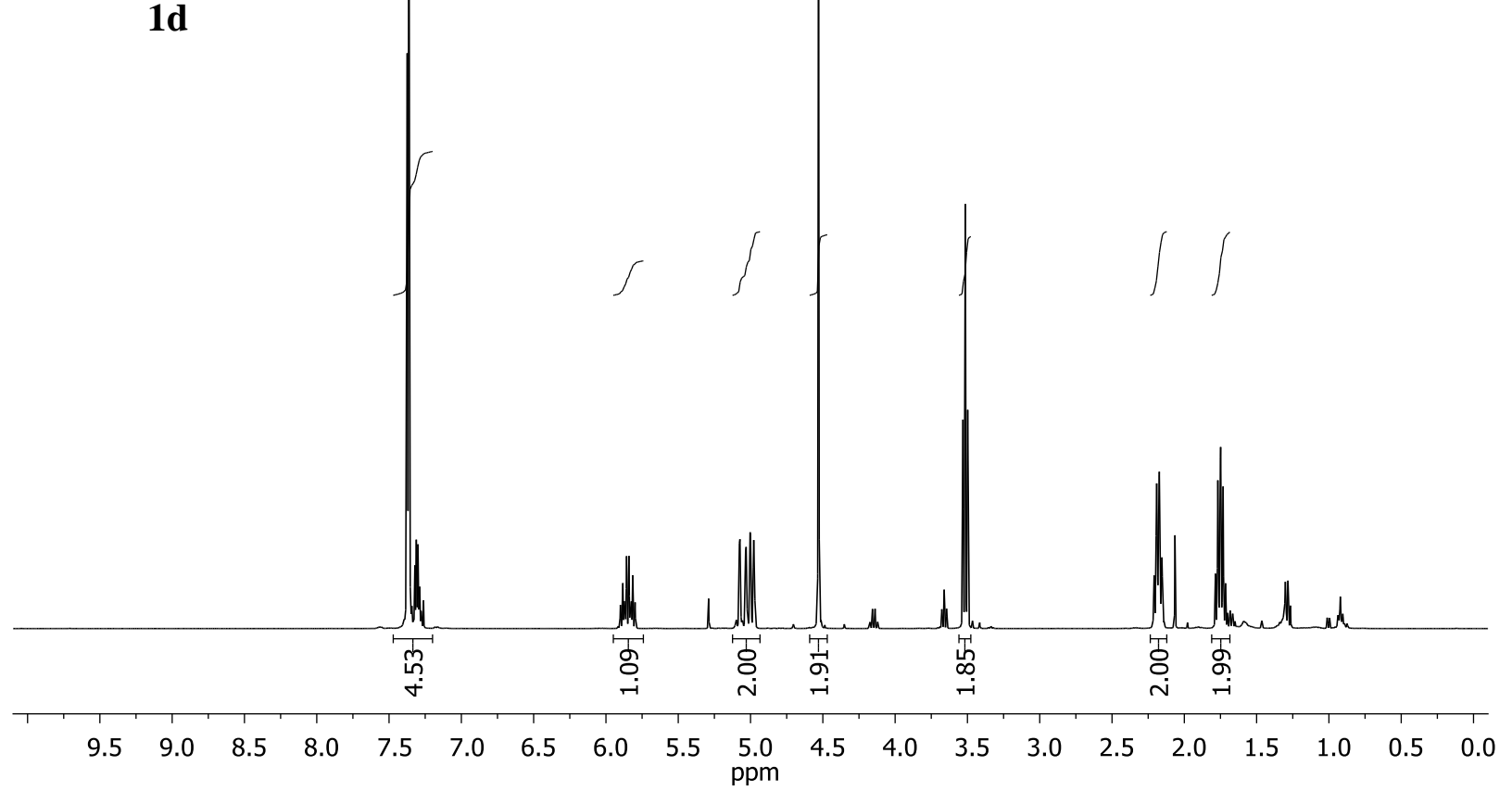

1-benzyloxypent-4-ene - CARBON
$\mathrm{CDCl3}$

1d

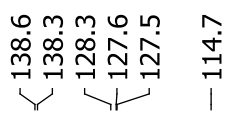

乐

ลิ ชิ่

11
ัั0 ํำ

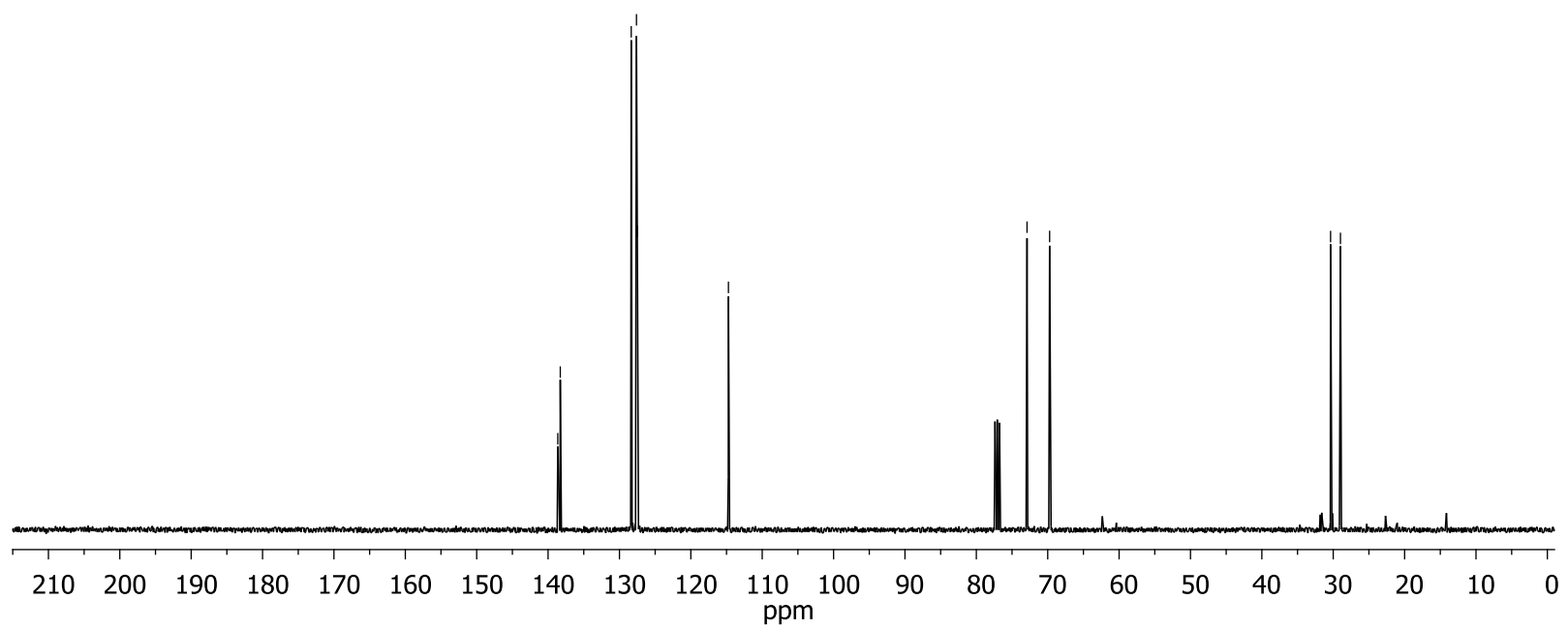



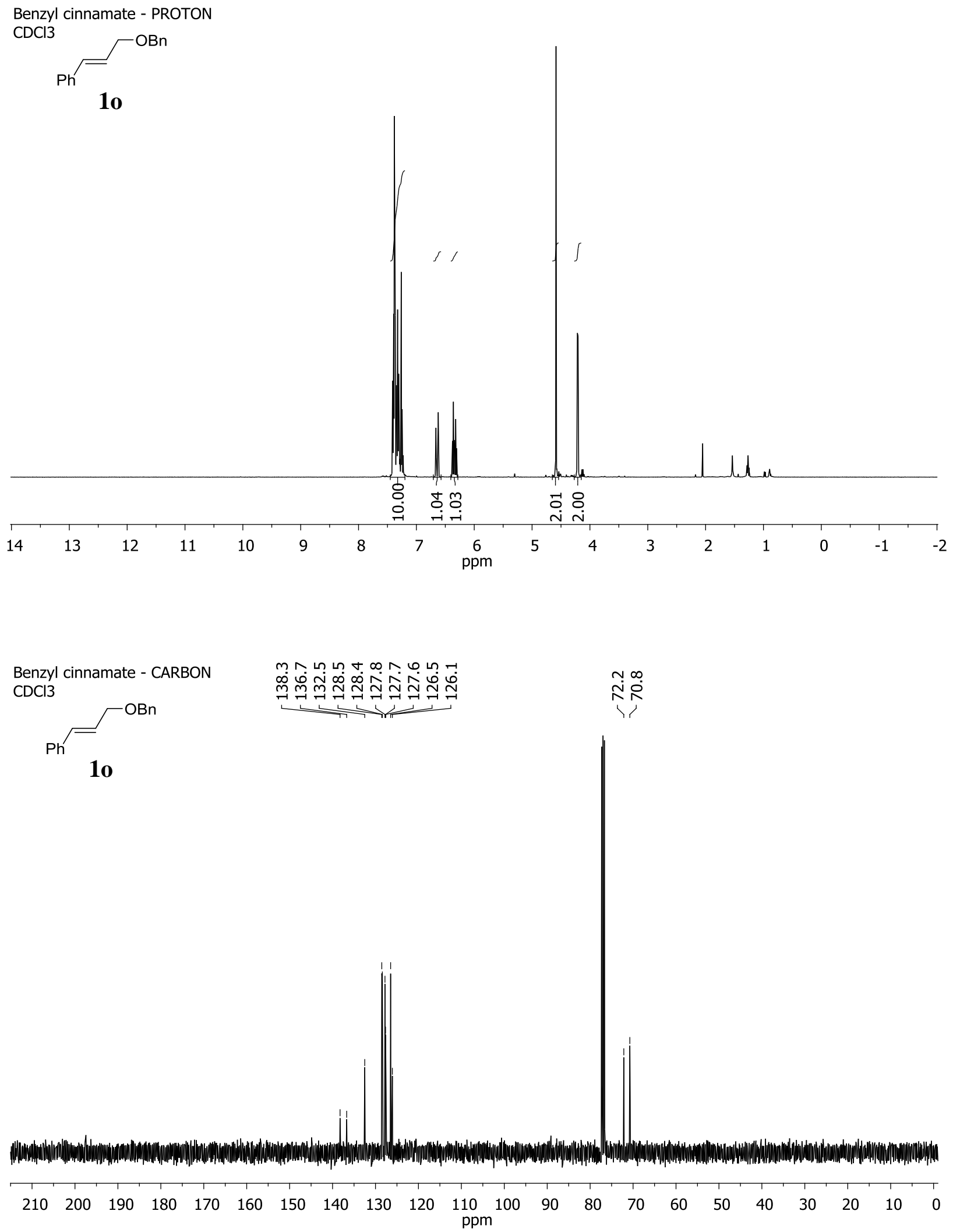

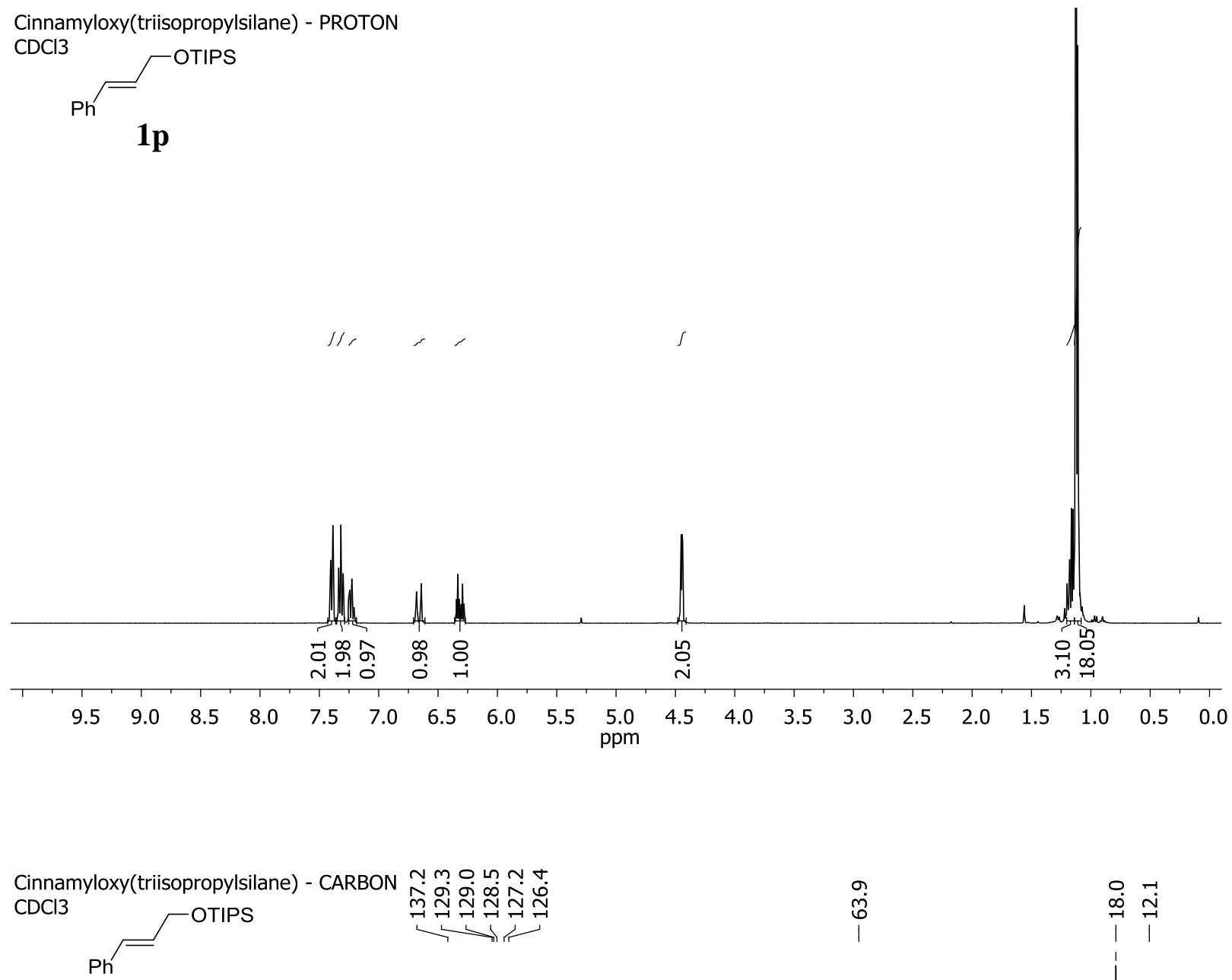

$1 p$

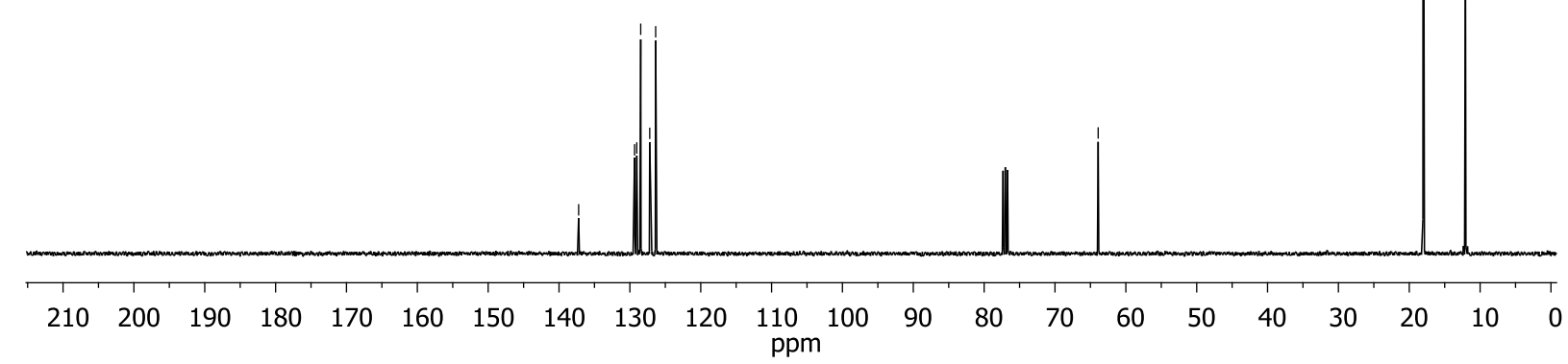


3,3-dimethyl-1-phenyl-but-1-ene:

$\mathrm{CDCl} 3$<smiles>CC(C)(C)/C=C/c1ccccc1</smiles>

$1 s$

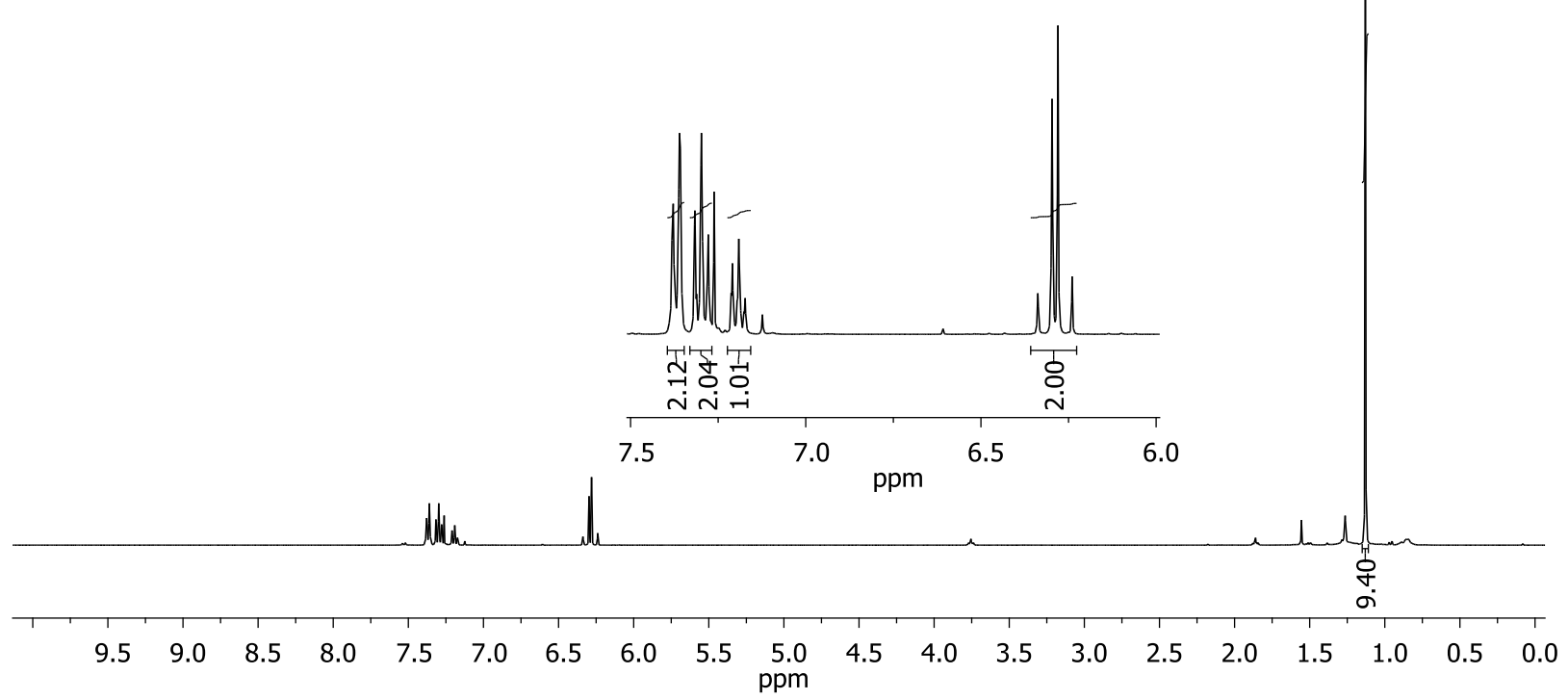

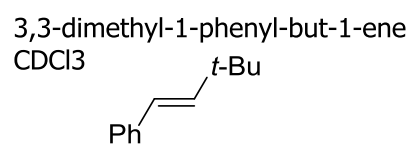

1s

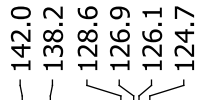

ตั จิ

11

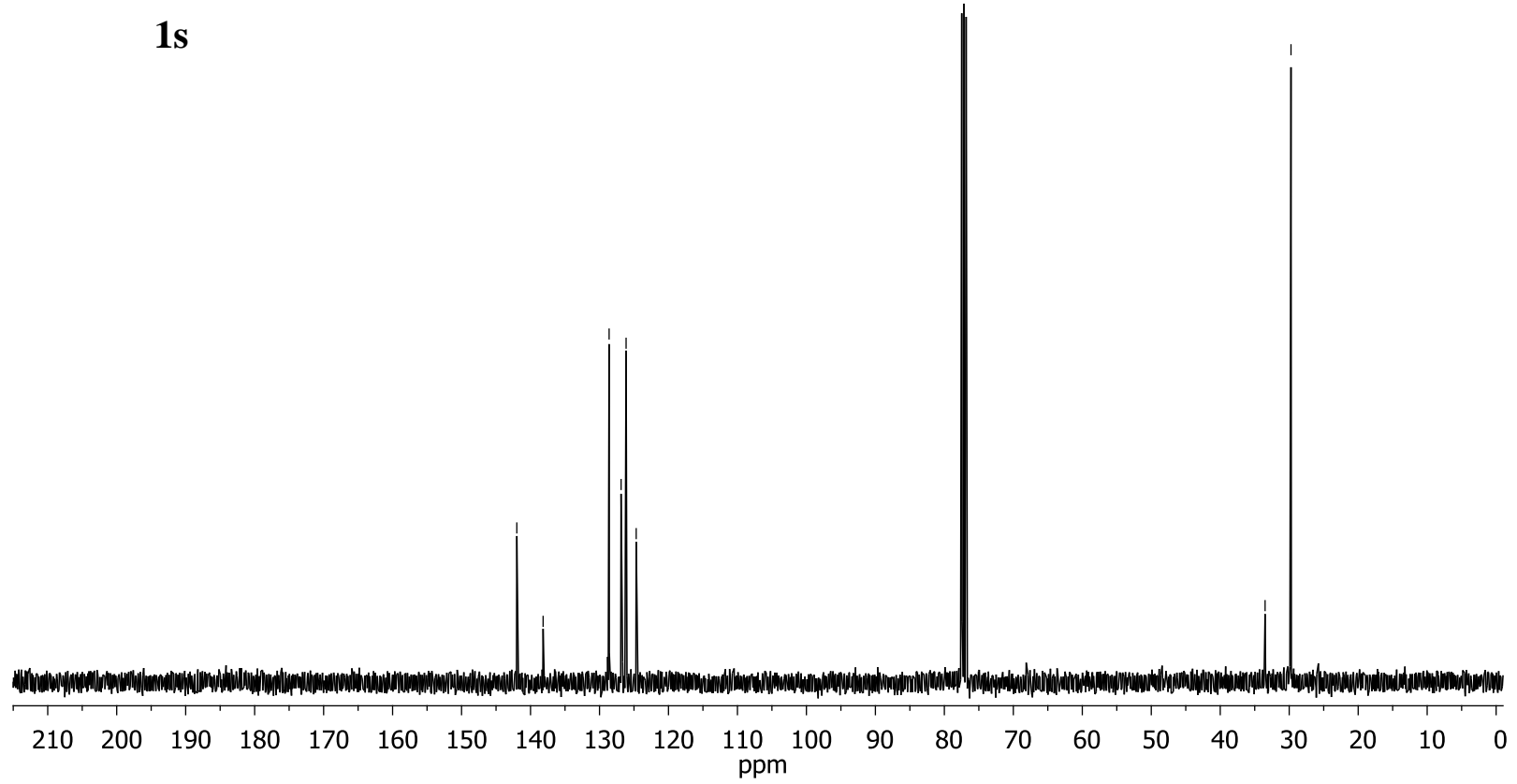




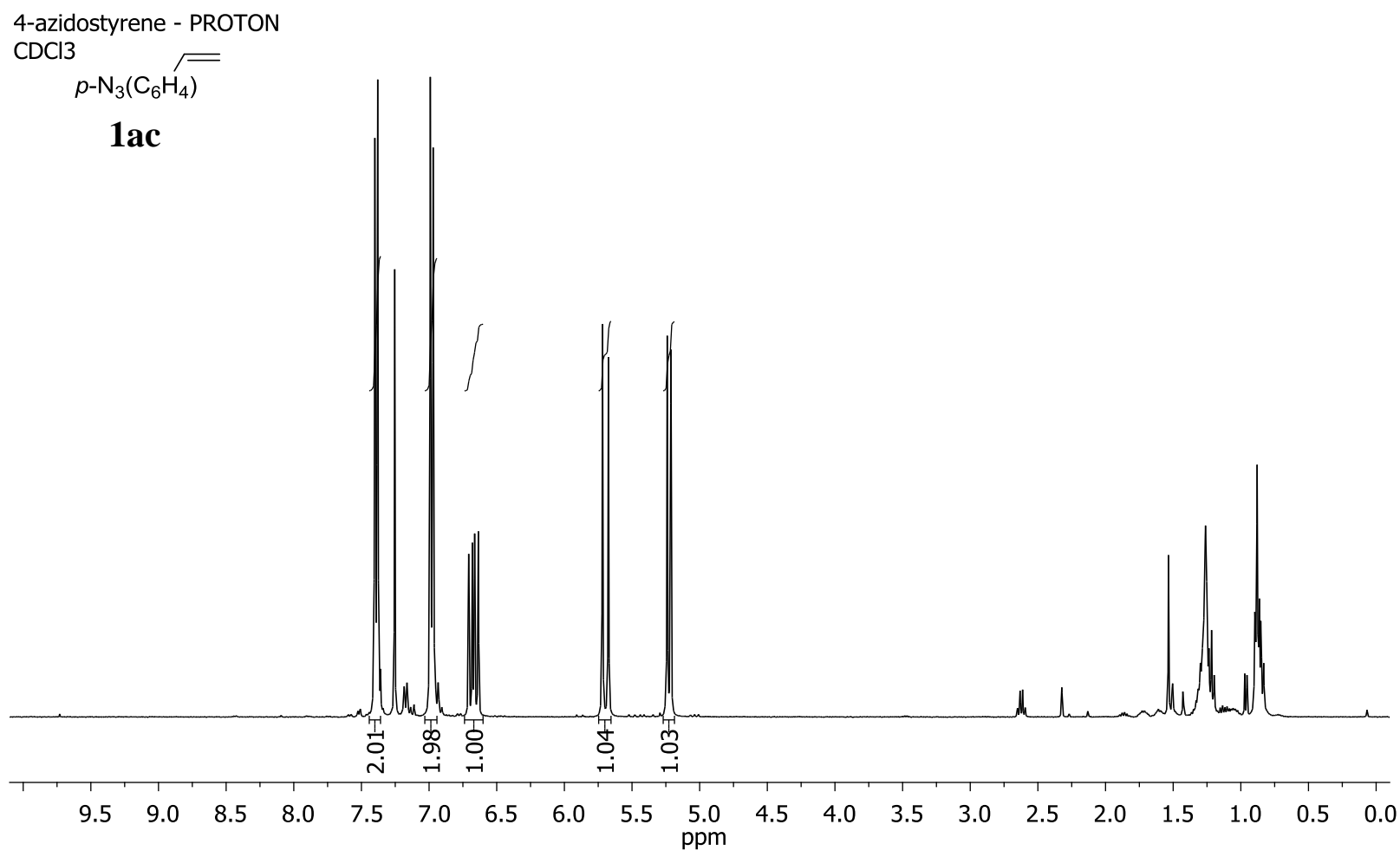
4-azidostyrene - CARBON
$\mathrm{CDCl} 3$
$\mathrm{p}-\mathrm{N}_{3}\left(\mathrm{C}_{6} \mathrm{H}_{4}\right)$

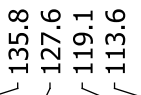
$\stackrel{\varphi}{m} \quad \stackrel{-}{\dot{+}}$

$1 \mathrm{ac}$

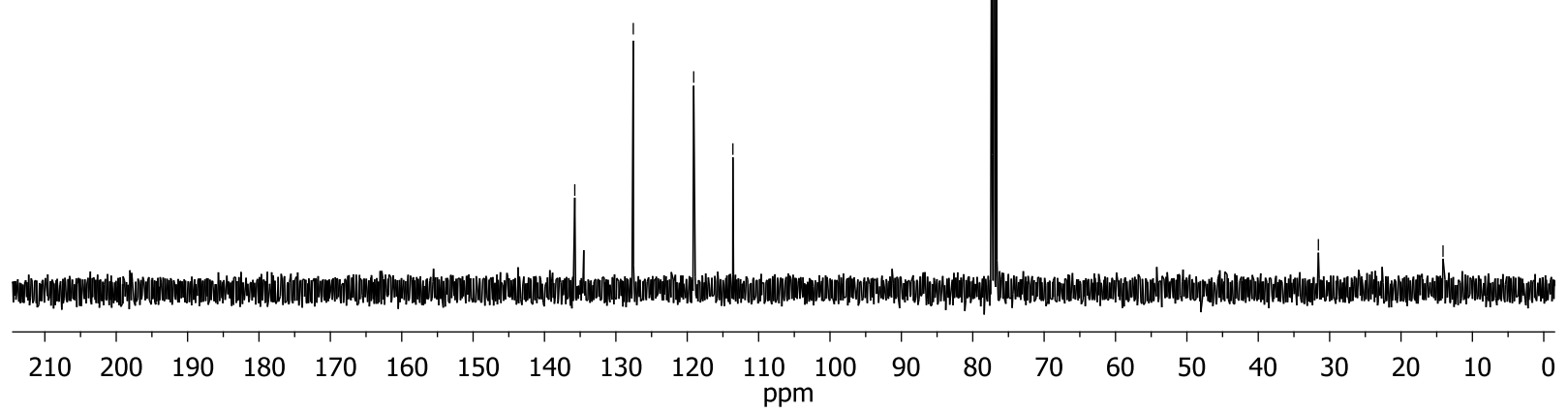


STREM - tetrahydroxydiboron - PROTON (CD3)2SO

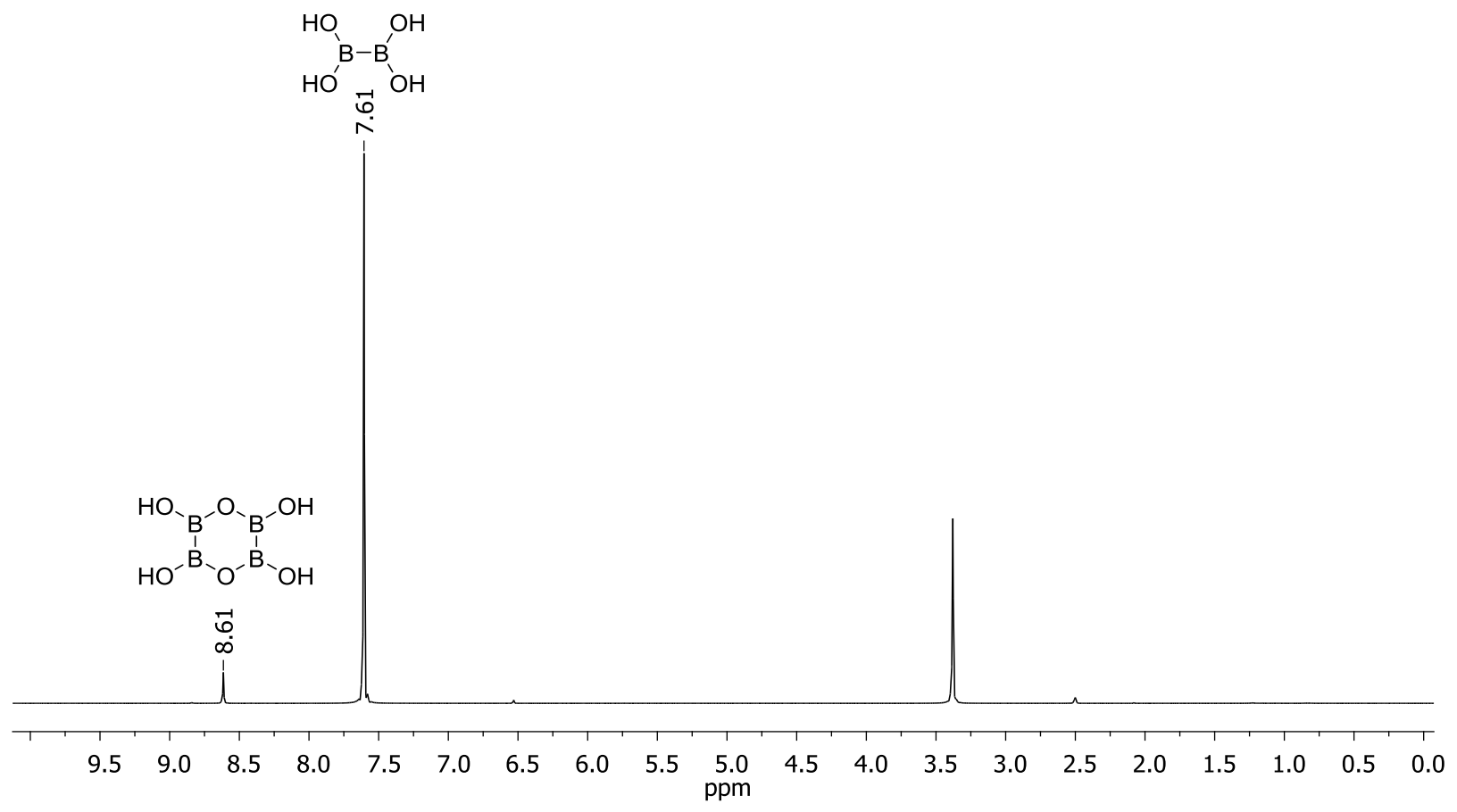

12212015 - deuterated tetrahydroxydiboron PROTON

$99.5 \%$ D2O used for the reaction

trimethoxybenzene included as standard

(CD3)2SO

$\mathrm{DO}^{\mathrm{B}-\mathrm{B}^{\prime}}$ OD
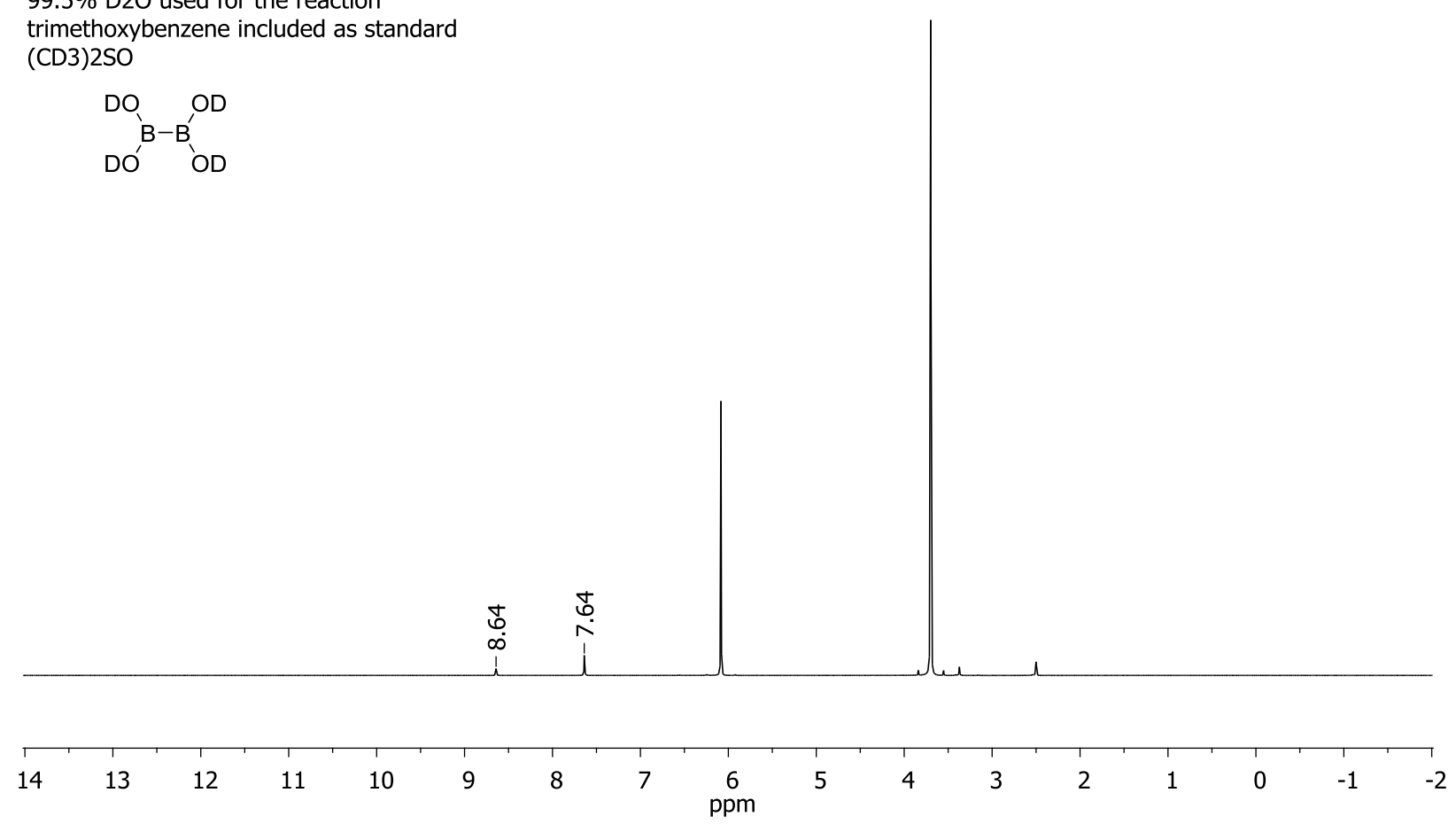
12232015 - deuterated tetrahydroxydiboron PROTON

$99.9 \%$ D2O used for the reaction

trimethoxybenzene included as standard

(CD3)2SO

DO' ${ }^{\mathrm{B}-\mathrm{B}^{\prime}}$

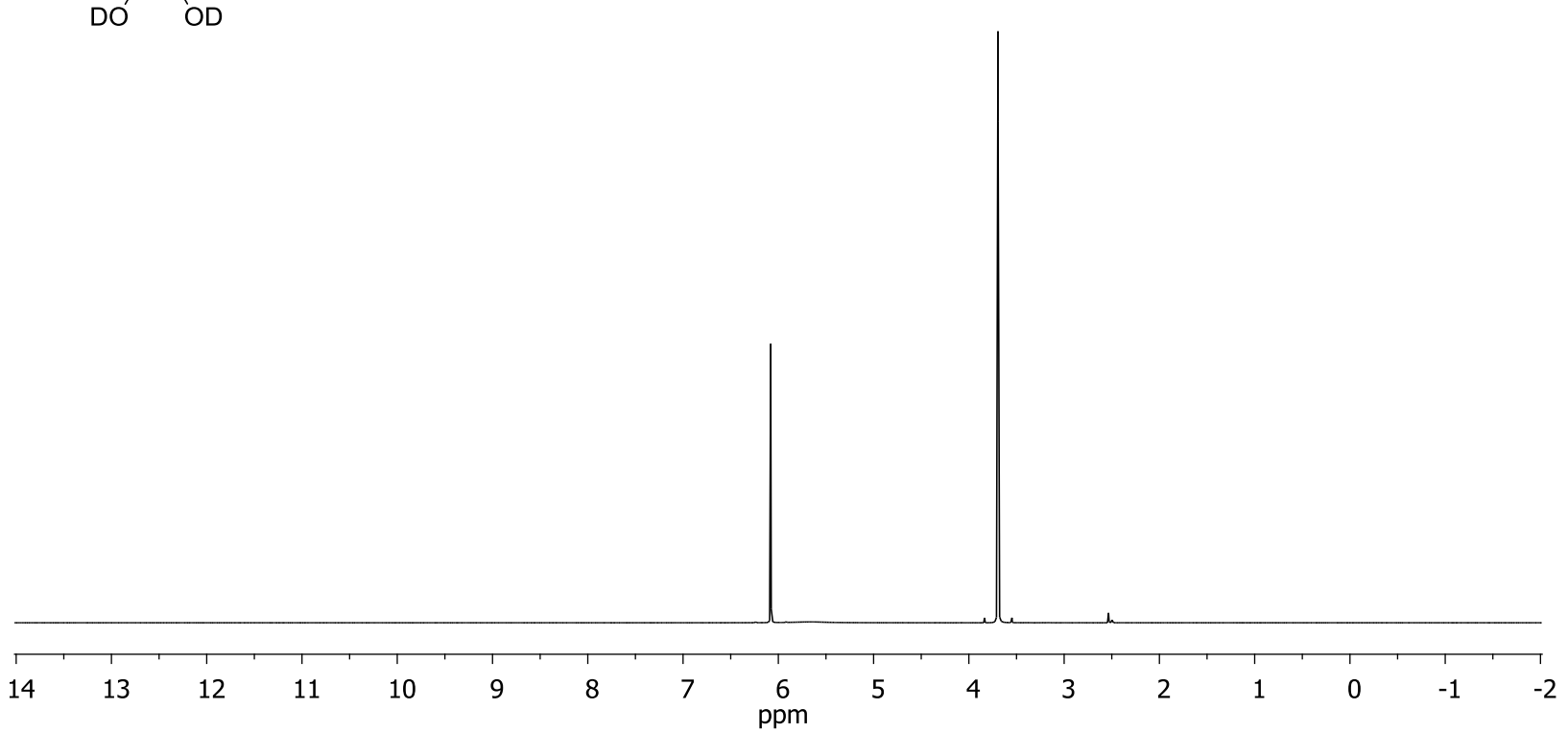

12212015 - deuterated tetrahydroxydiboron PROTON

99.5\% D2O used for the reaction

trimethoxybenzene included as standard

(CD3)2SO

DO' ${ }^{\mathrm{B}-\mathrm{B}^{\prime}}$ OD

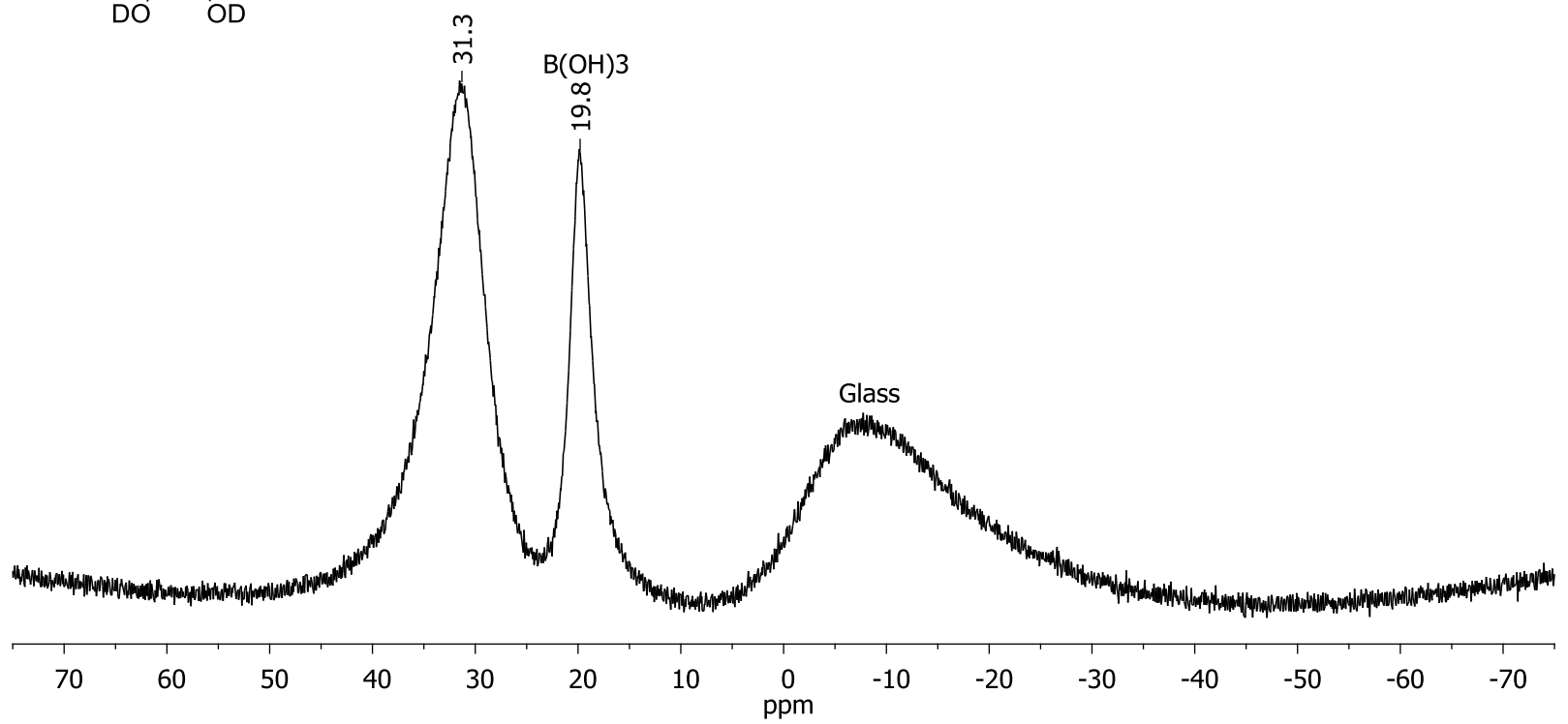




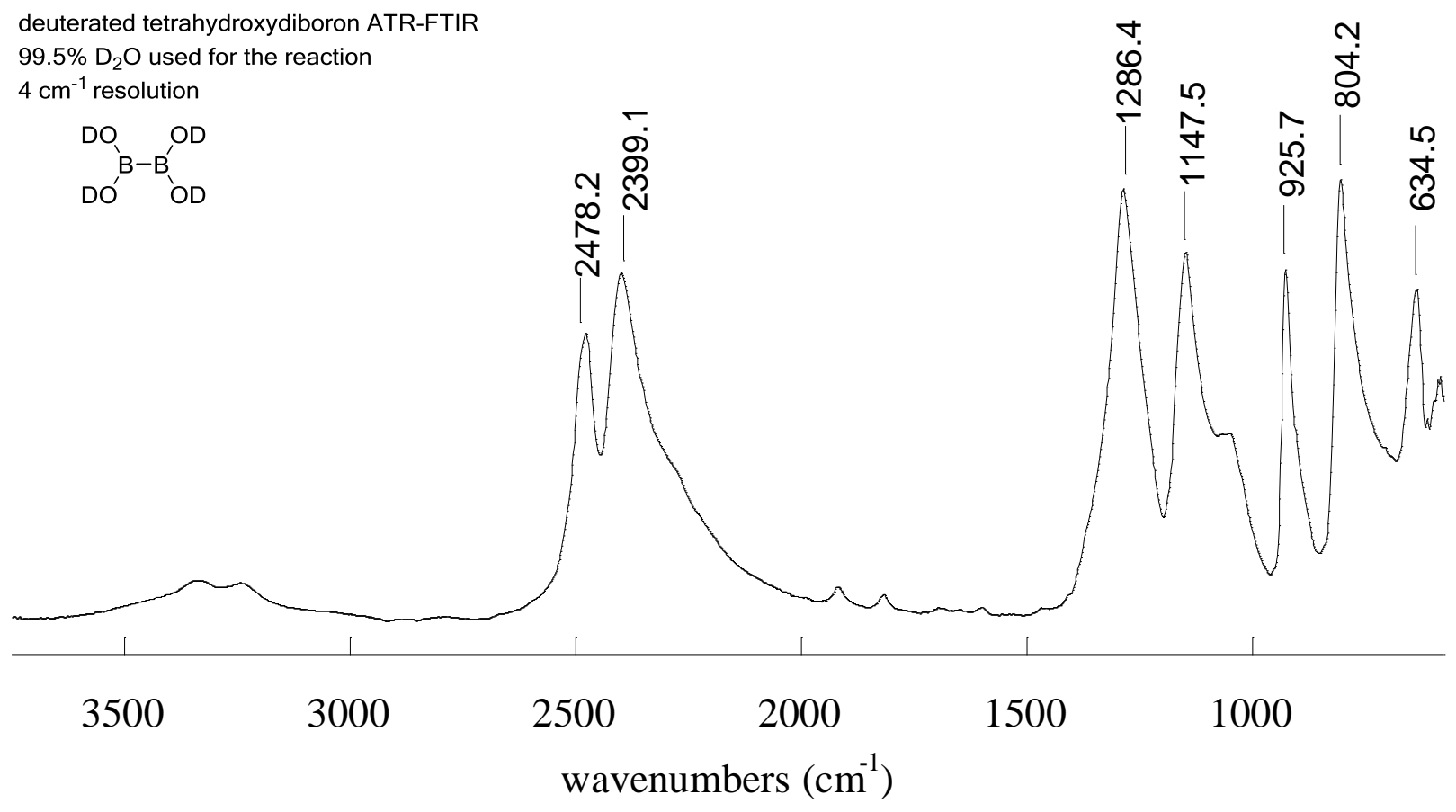




\section{B. ${ }^{1} \mathrm{H}$ and ${ }^{13} \mathrm{C}$ NMR Spectra of 2a-2ag}

1,1-diphenylethylene - PRESAT

$\mathrm{CH}_{2} \mathrm{Cl} 2$
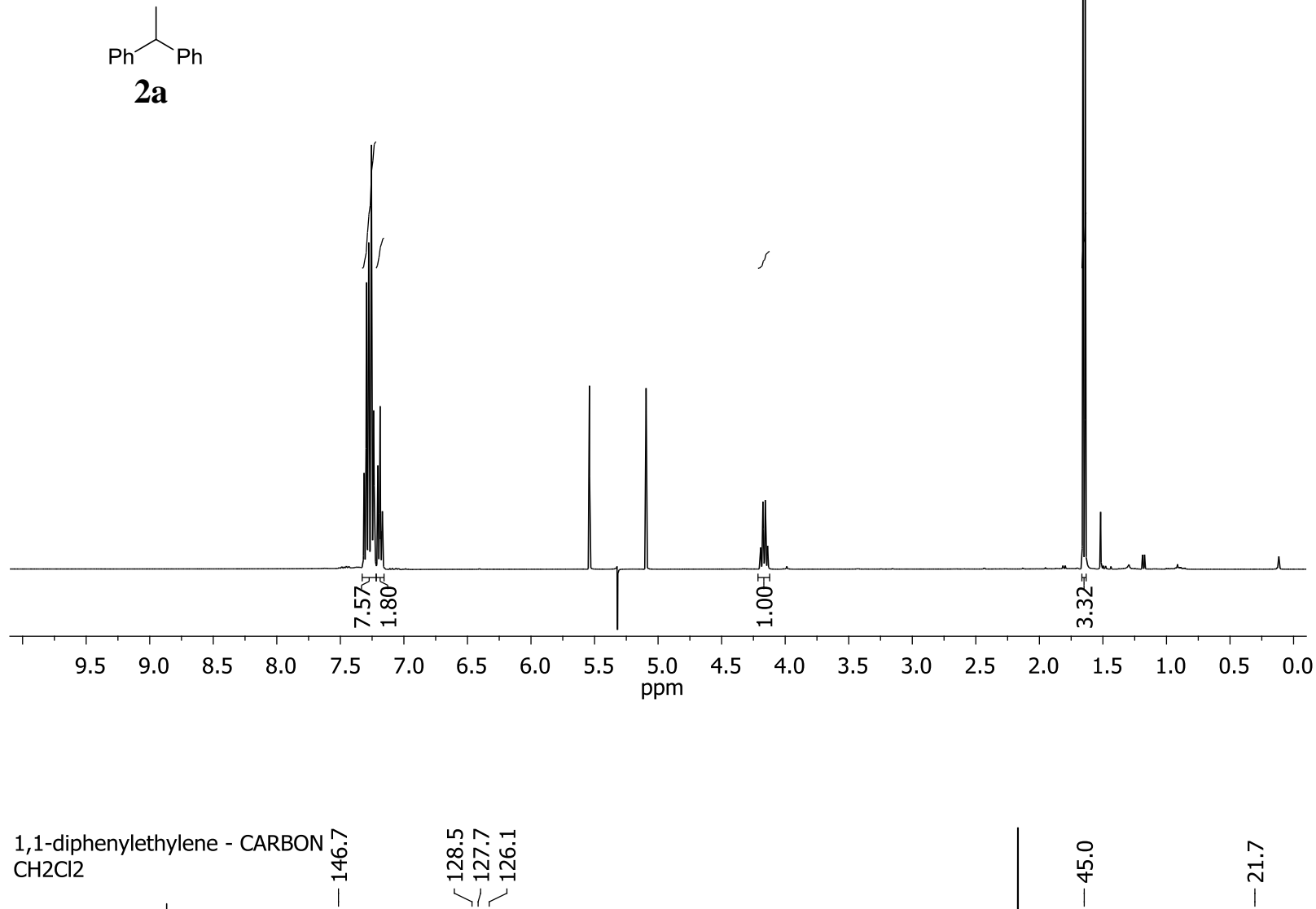

$\overbrace{\mathrm{Ph}}$

$2 \mathbf{a}$

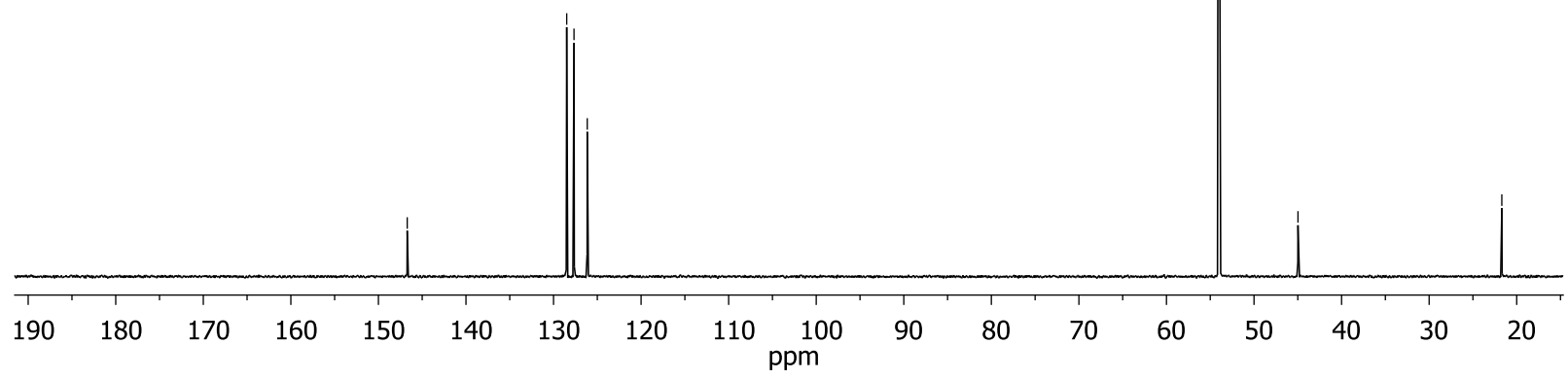


octene - PRESAT
$\mathrm{CH} 2 \mathrm{Cl}$

2b
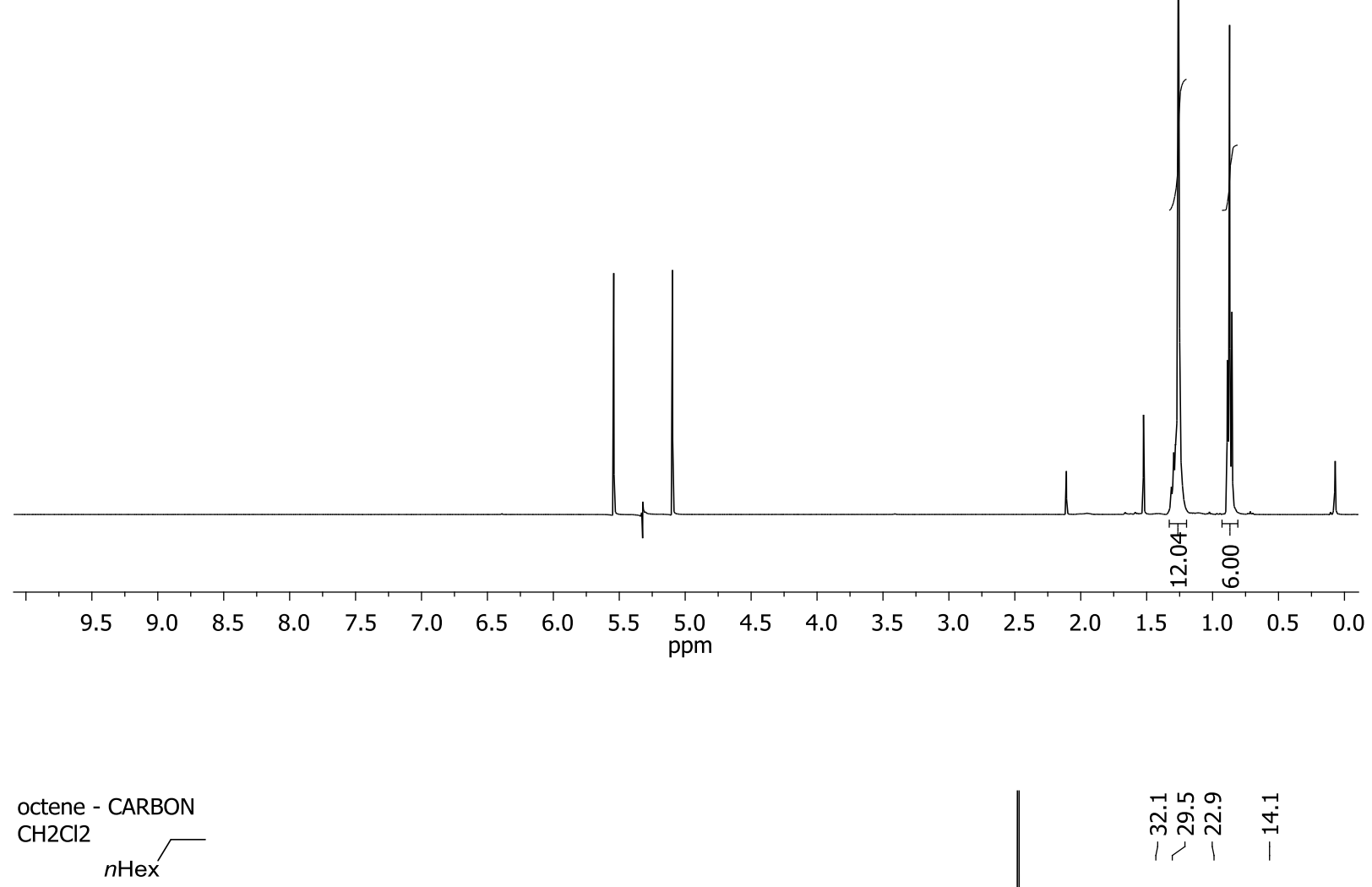

2b

กั่ 
4-penten-1-ol - PRESAT

$\mathrm{CH} 2 \mathrm{Cl} 2 \mathrm{HO}+{ }_{3}$

2c

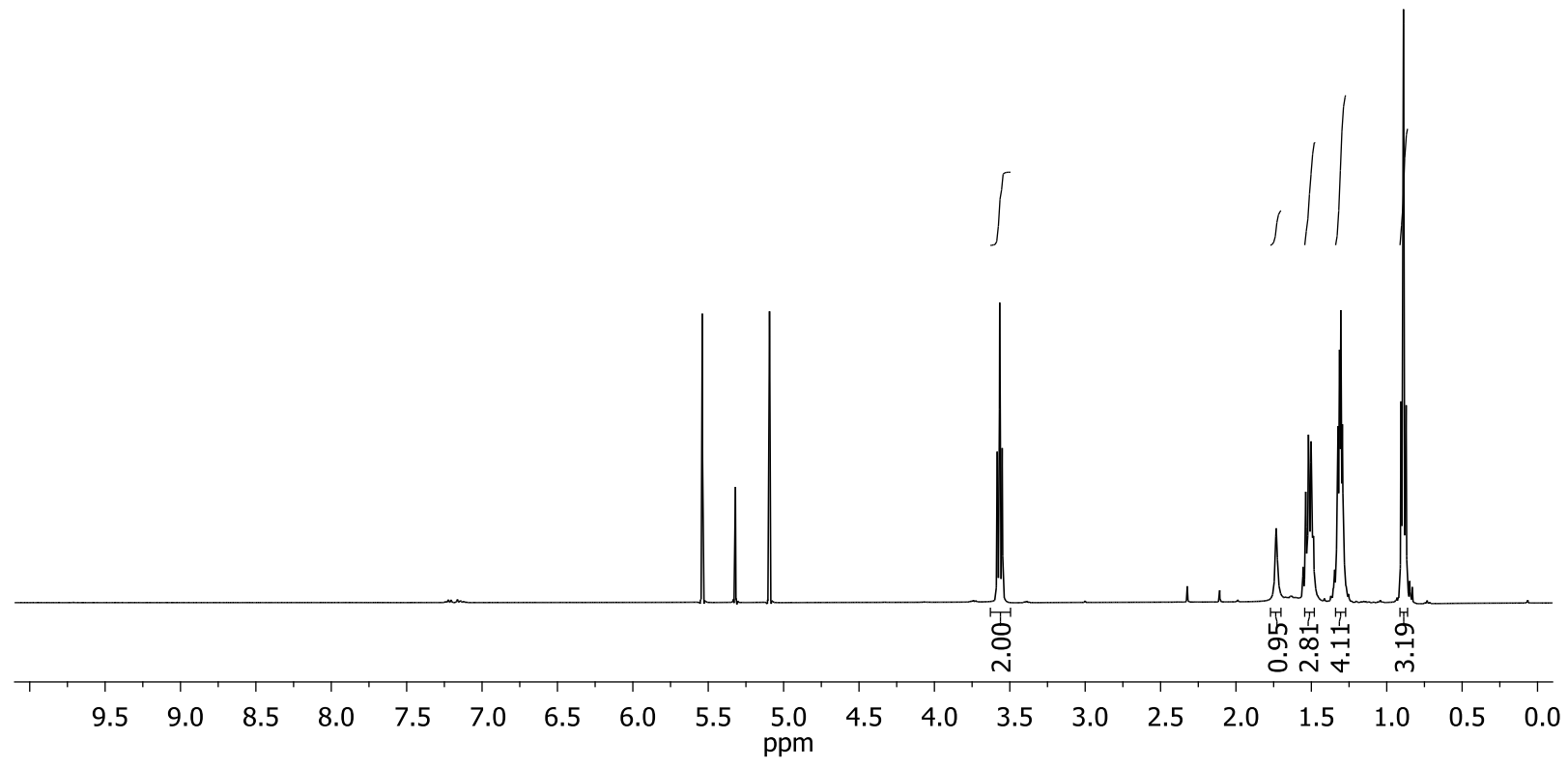

4-penten-1-ol - CARBON

$\mathrm{CH} 2 \mathrm{Cl} 2$

$\mathrm{HO}+\sqrt{3}$

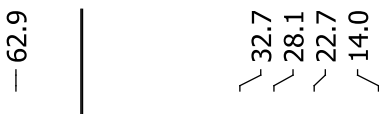

2c

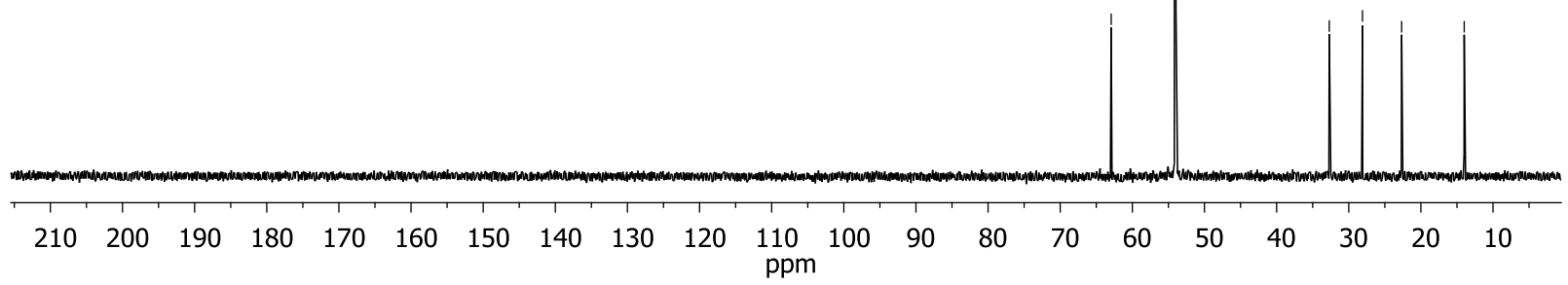




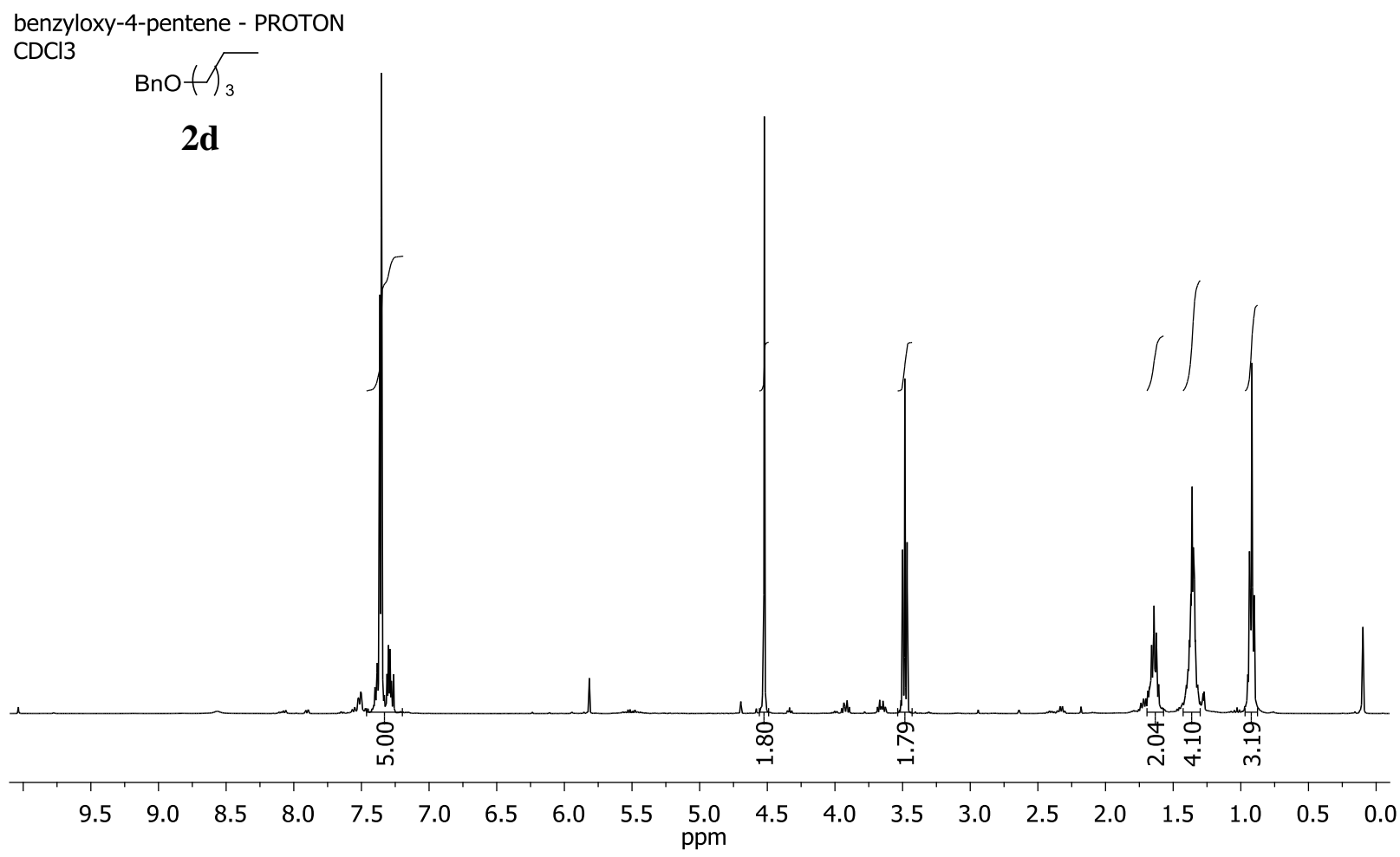

benzyloxy-4-pentene - CARBON $\mathrm{CDCl} 3$ $\mathrm{BnO}+{ }_{3}$

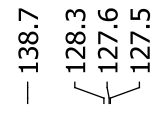

กัก

กำ

ก 6 กิํำ

2d

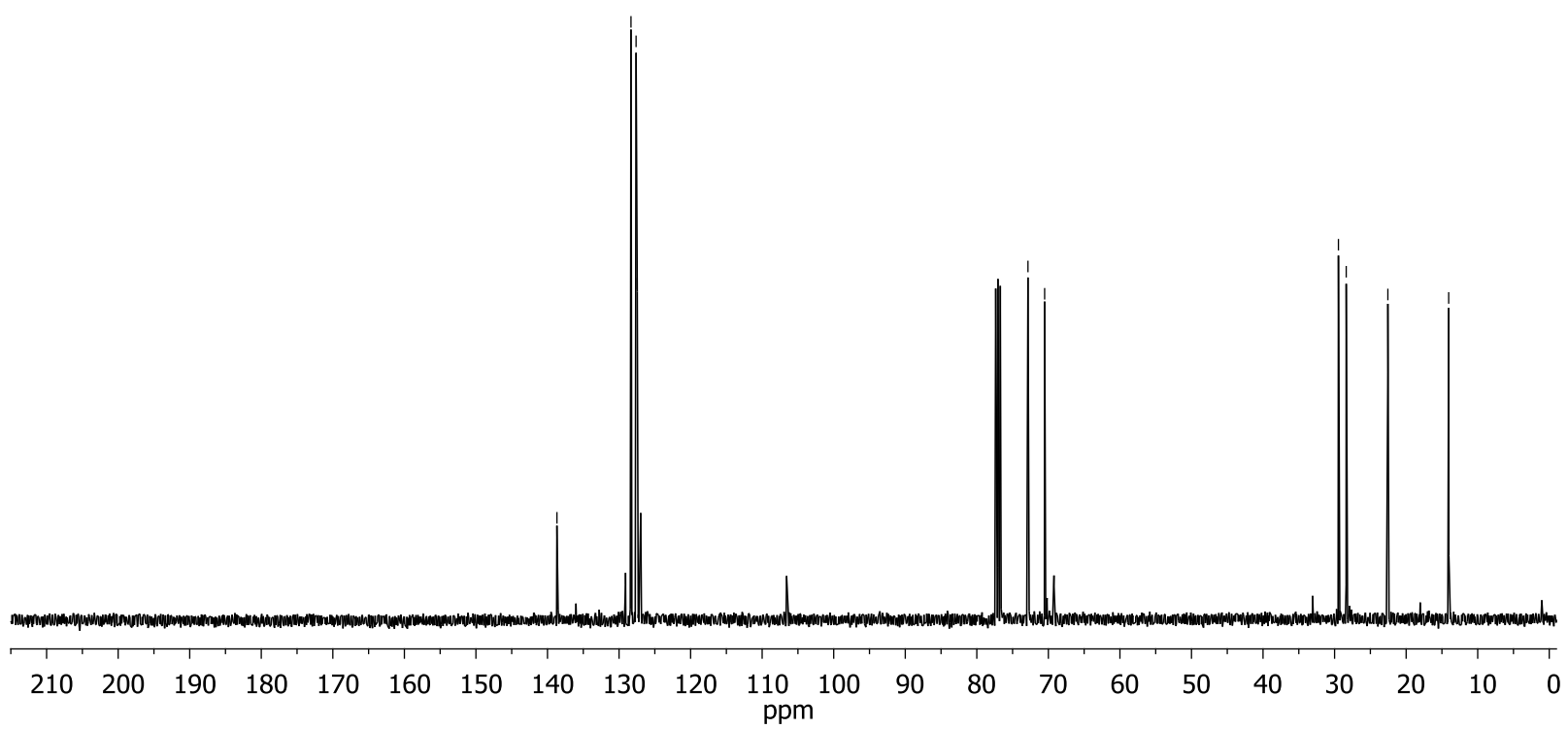


diethyl allyImalonate - PRESAT

$\mathrm{CH} 2 \mathrm{Cl} 2$
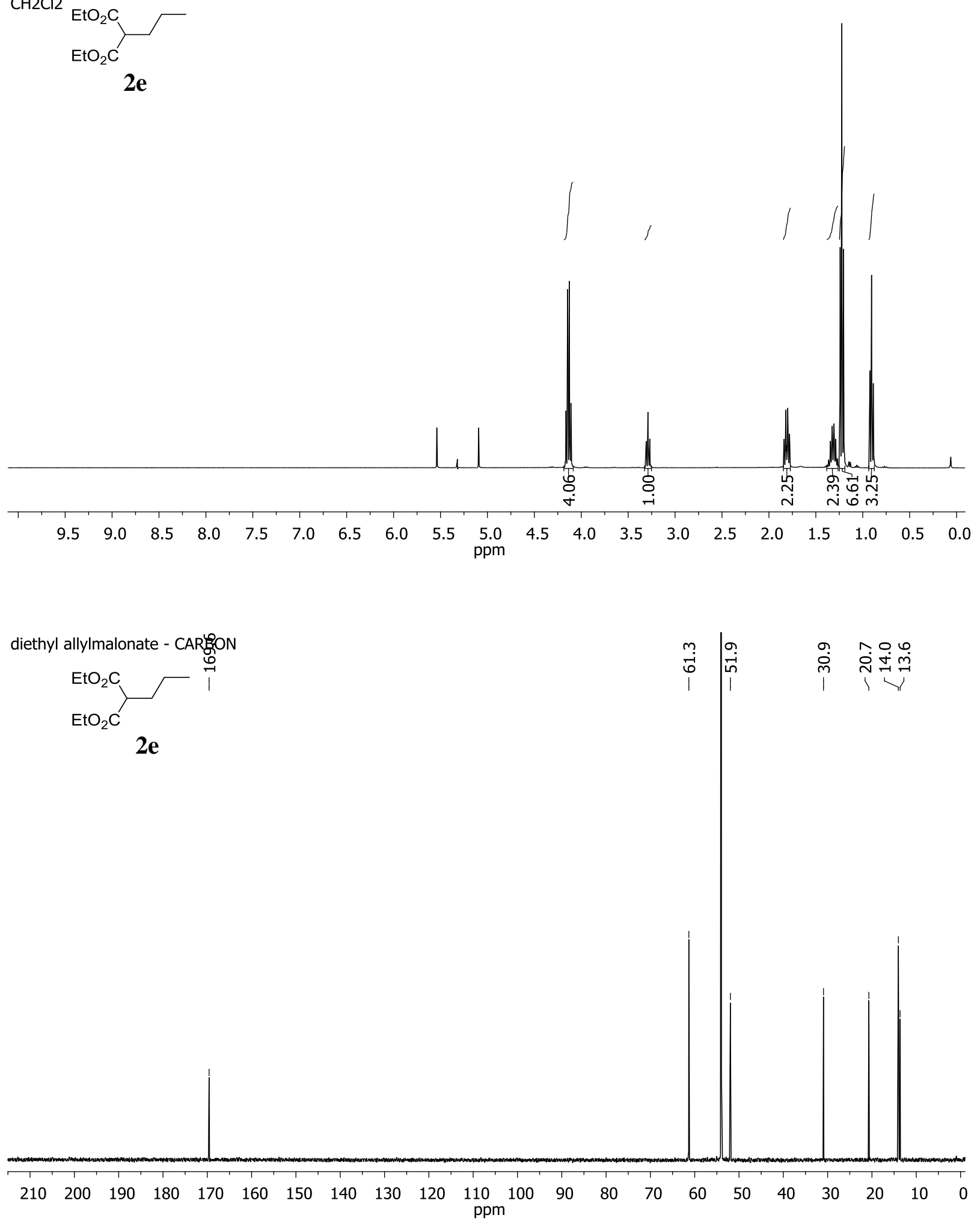
ethyl vinylketone - PRESAT

$\mathrm{CH} 2 \mathrm{Cl} 2$<smiles>CCC(=O)CC</smiles>

$2 f$

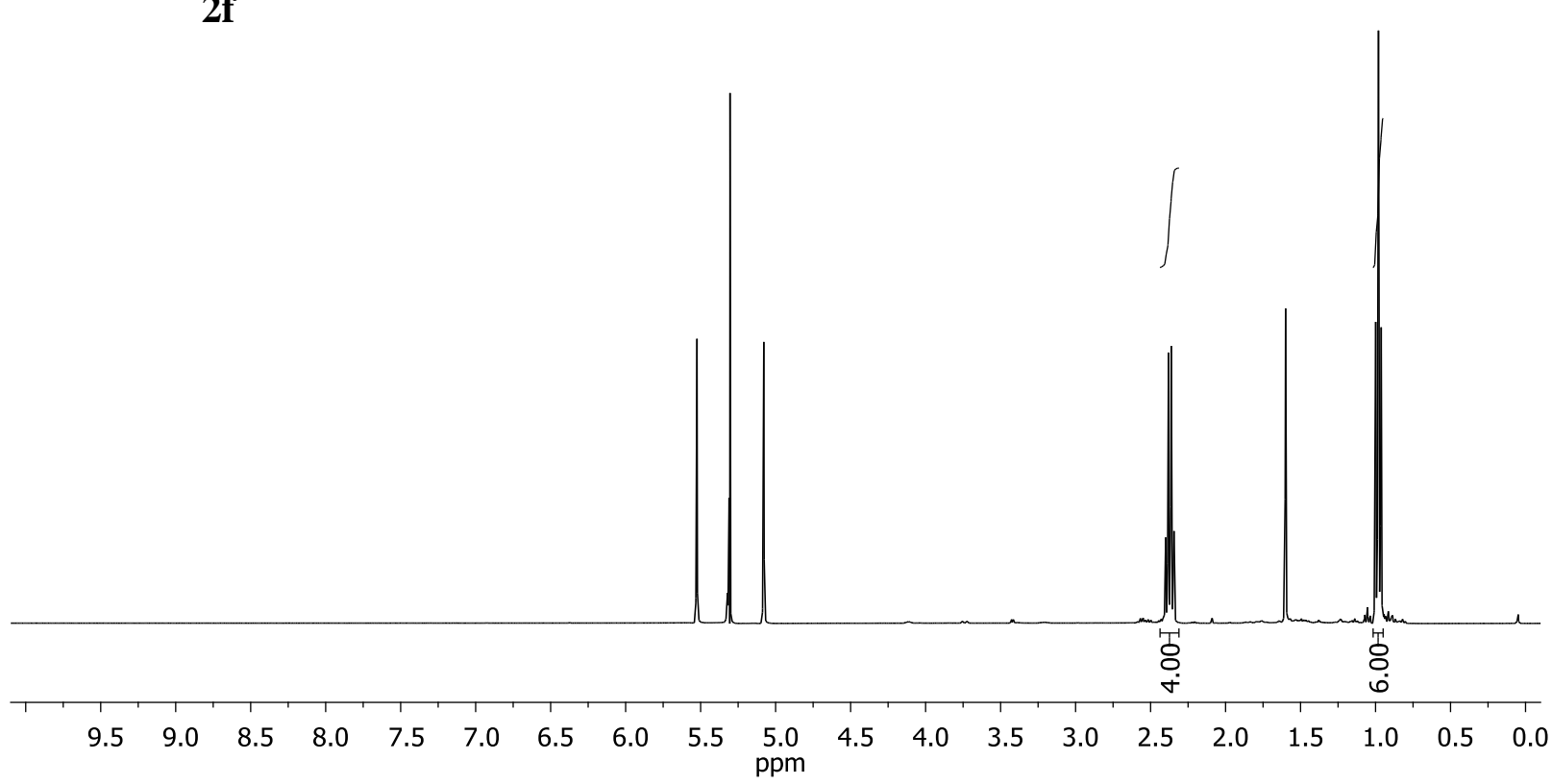

$\stackrel{\text { i ethyl vinylketone - CARBON }}{\underset{\mathrm{N}}{\mathrm{C}} \mathrm{CH} 2 \mathrm{Cl} 2}$

$2 f$
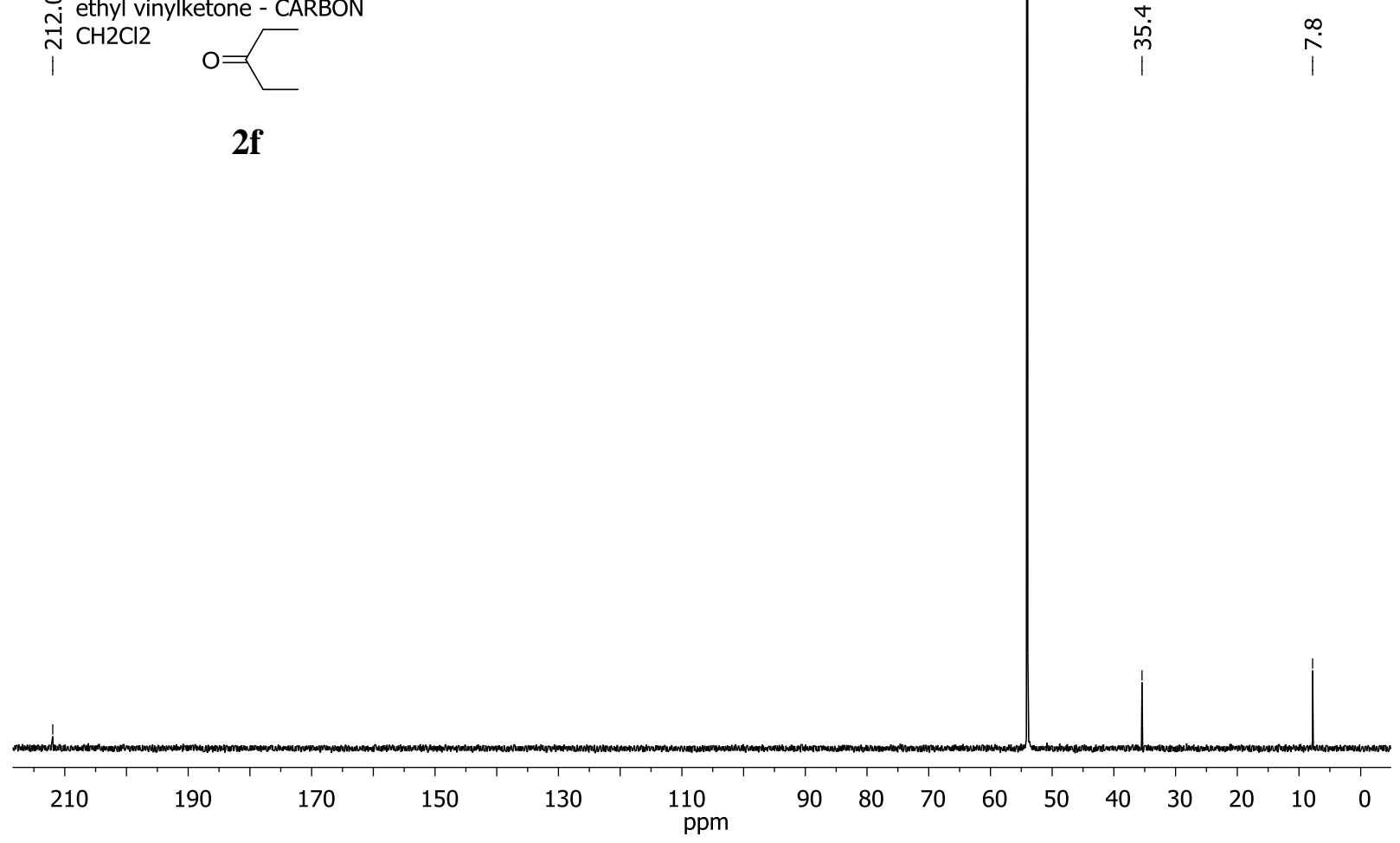


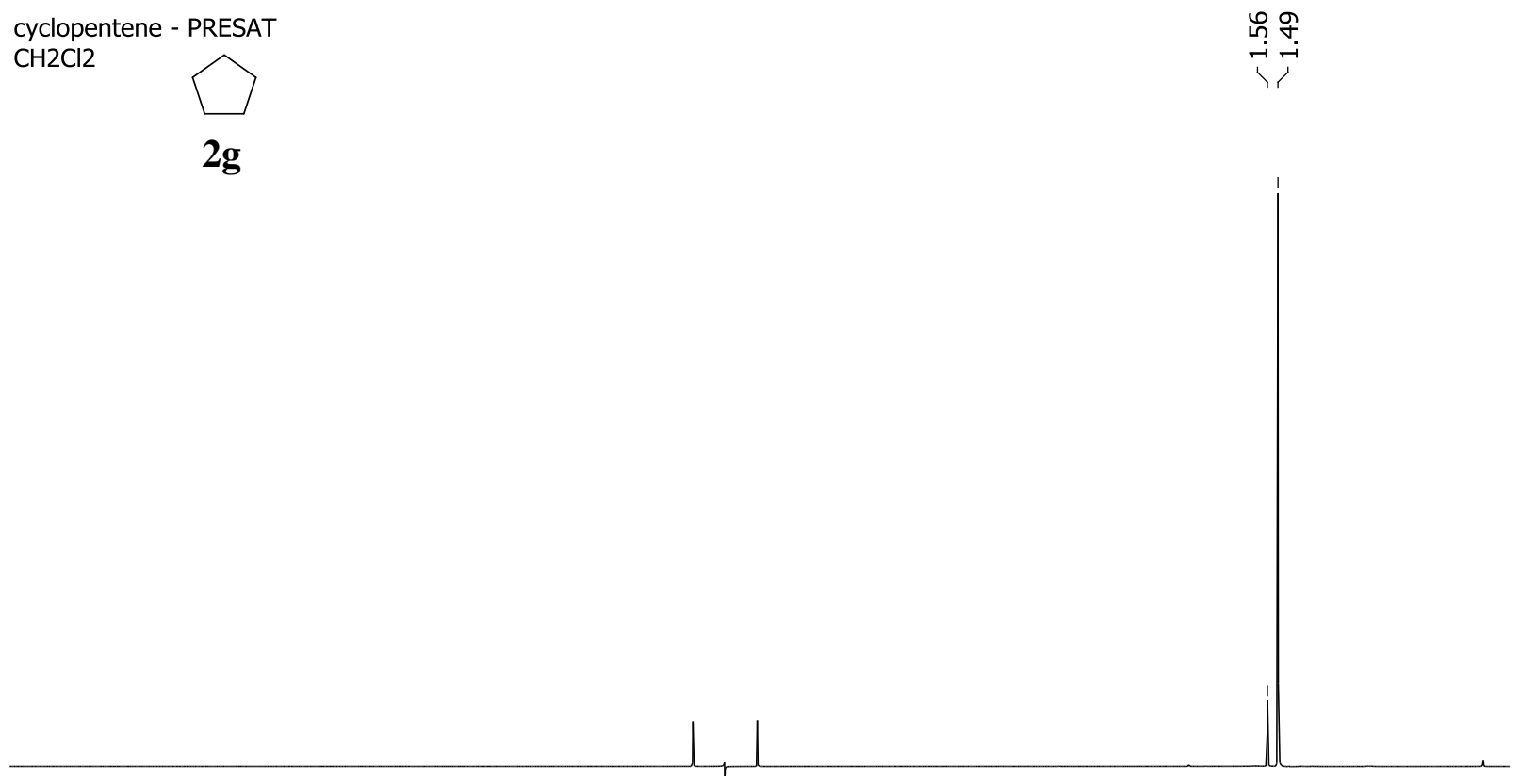

\begin{tabular}{llllllllllllllllllll}
\hline 9.5 & 9.0 & 8.5 & 8.0 & 7.5 & 7.0 & 6.5 & 6.0 & 5.5 & $\begin{array}{r}5.0 \\
\mathrm{ppm}\end{array}$ & 4.5 & 4.0 & 3.5 & 3.0 & 2.5 & 2.0 & 1.5 & 1.0 & 0.5 & 0.0
\end{tabular}

cyclopentene - CARBON $\mathrm{CH}_{2} \mathrm{Cl} 2$
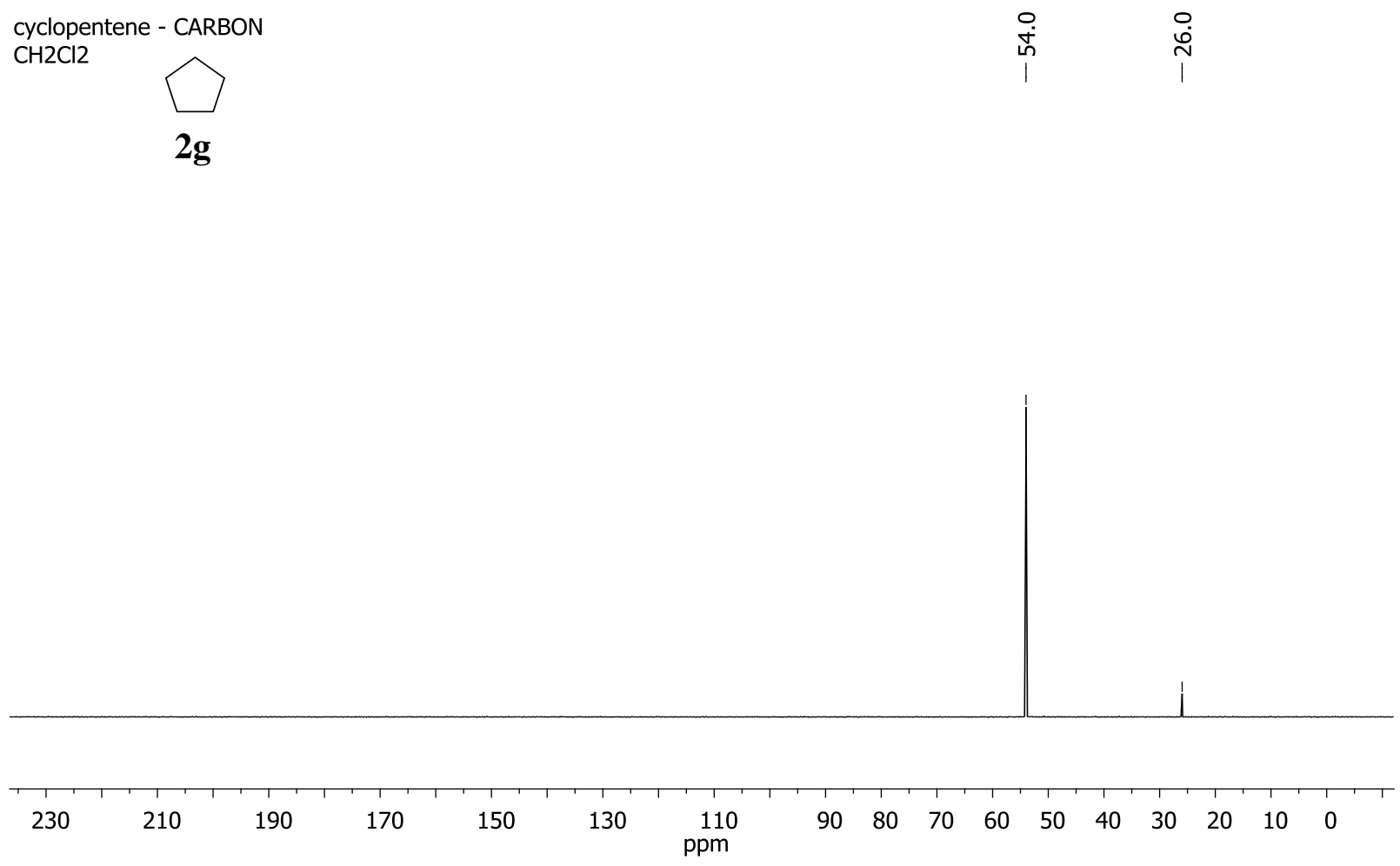
bicyclo[2.2.1] hept-2-ene - PRESAT

$\mathrm{CH} 2 \mathrm{Cl} 2$

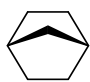

2h

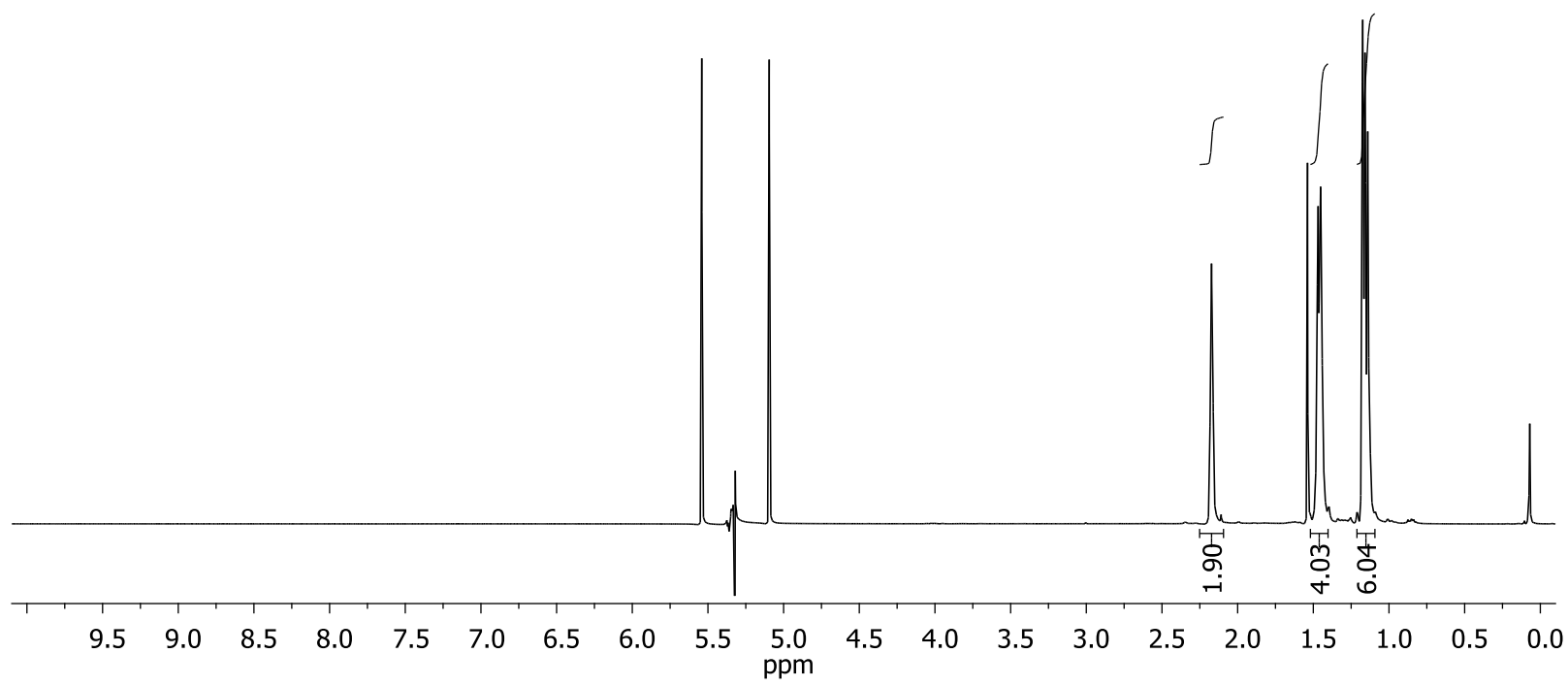

bicyclo[2.2.1]hept-2-ene - CARBON $\mathrm{CH} 2 \mathrm{Cl} 2$

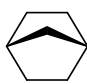

岗芦芯

2h

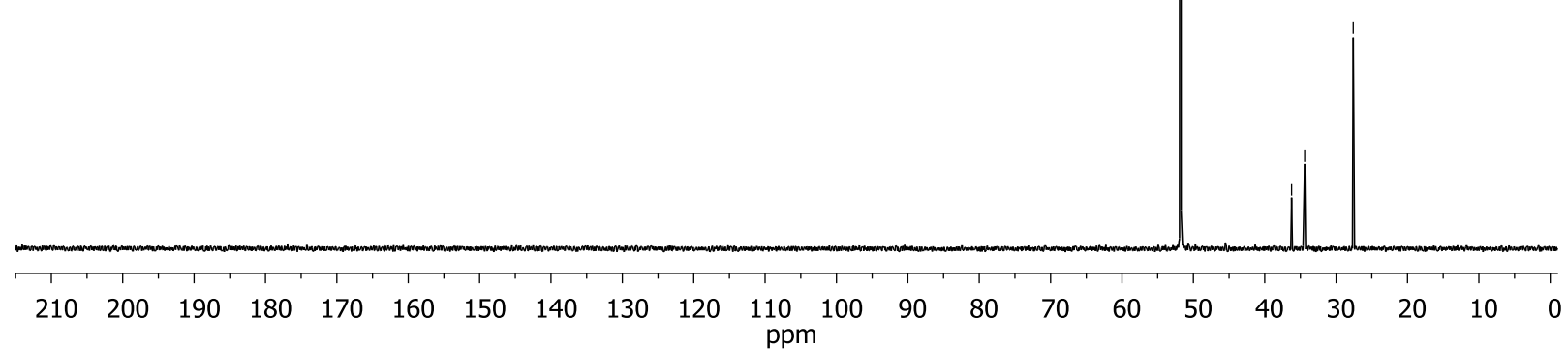


2,5-dihydrofuran - PRESAT

$\mathrm{CH} 2 \mathrm{Cl} 2$

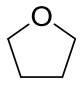

$2 \mathbf{i}$

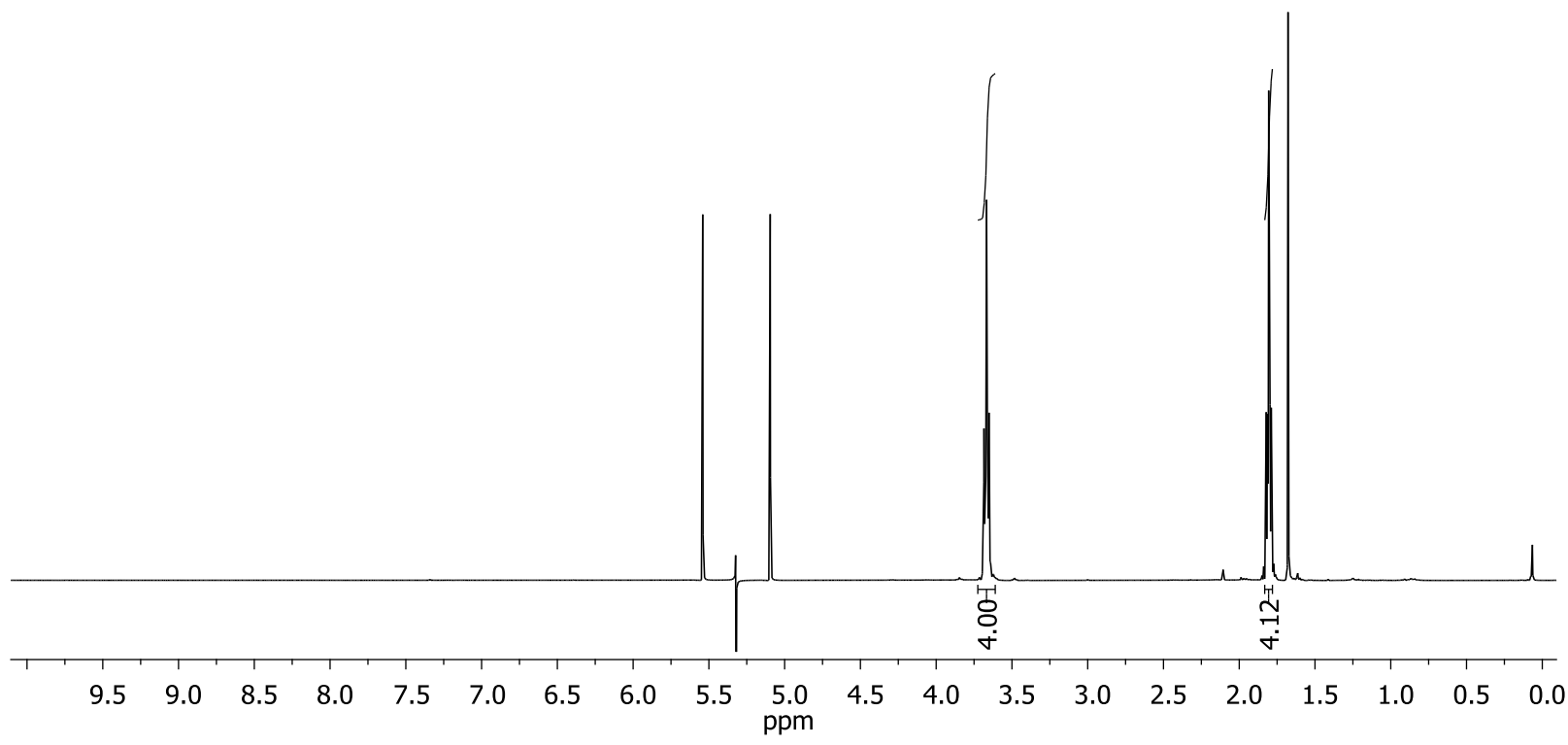

2,5-dihydrofuran - CARBON

$\mathrm{CH} 2 \mathrm{Cl} 2$

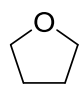

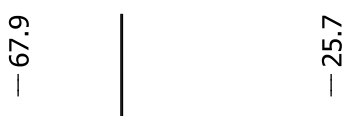

$2 \mathbf{i}$

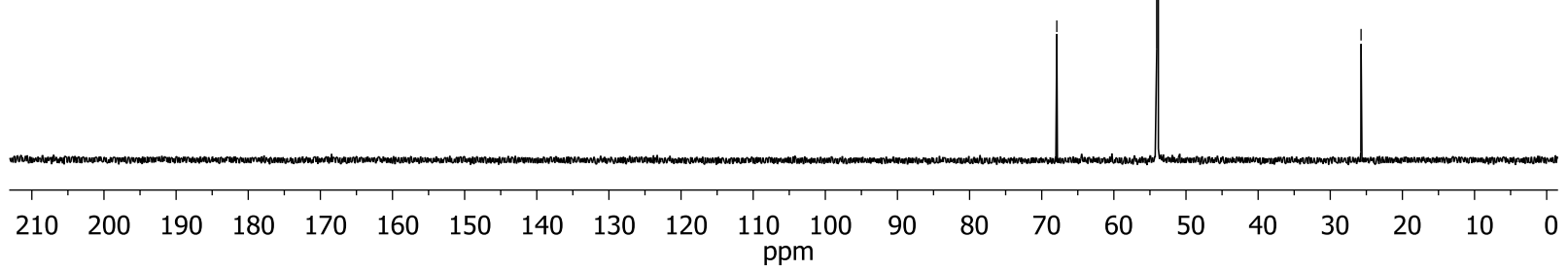


N-Boc-pyrrole - PRESAT

$\mathrm{CH} 2 \mathrm{Cl} 2$<smiles>O=C1CCCC1</smiles>

$2 \mathbf{j}$

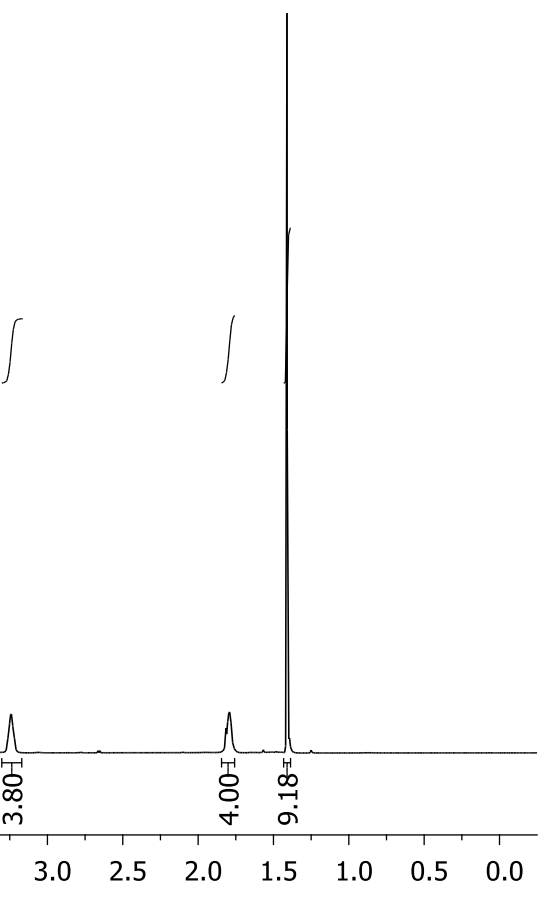

N-Boc-pyrrole - CARBON
$\mathrm{CH} 2 \mathrm{Cl} 2$

$2 \mathrm{j}$



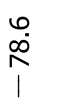
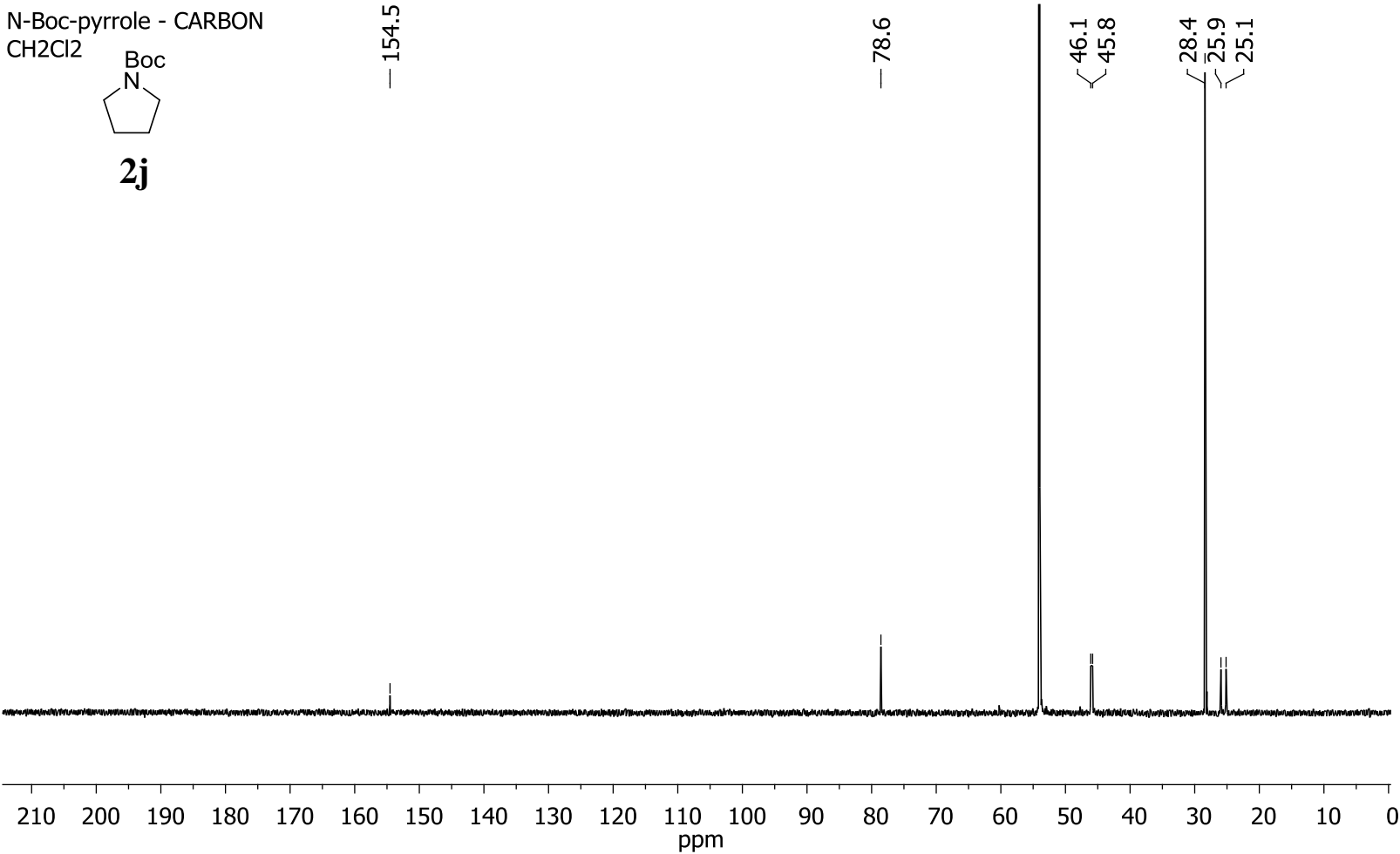
1-chlorocyclopentene reduction - PRESAT

23.0mg 1,3,5-trimethoxybenzene

$\mathrm{CH} 2 \mathrm{Cl} 2$<smiles>ClC1CCCC1</smiles>

2k

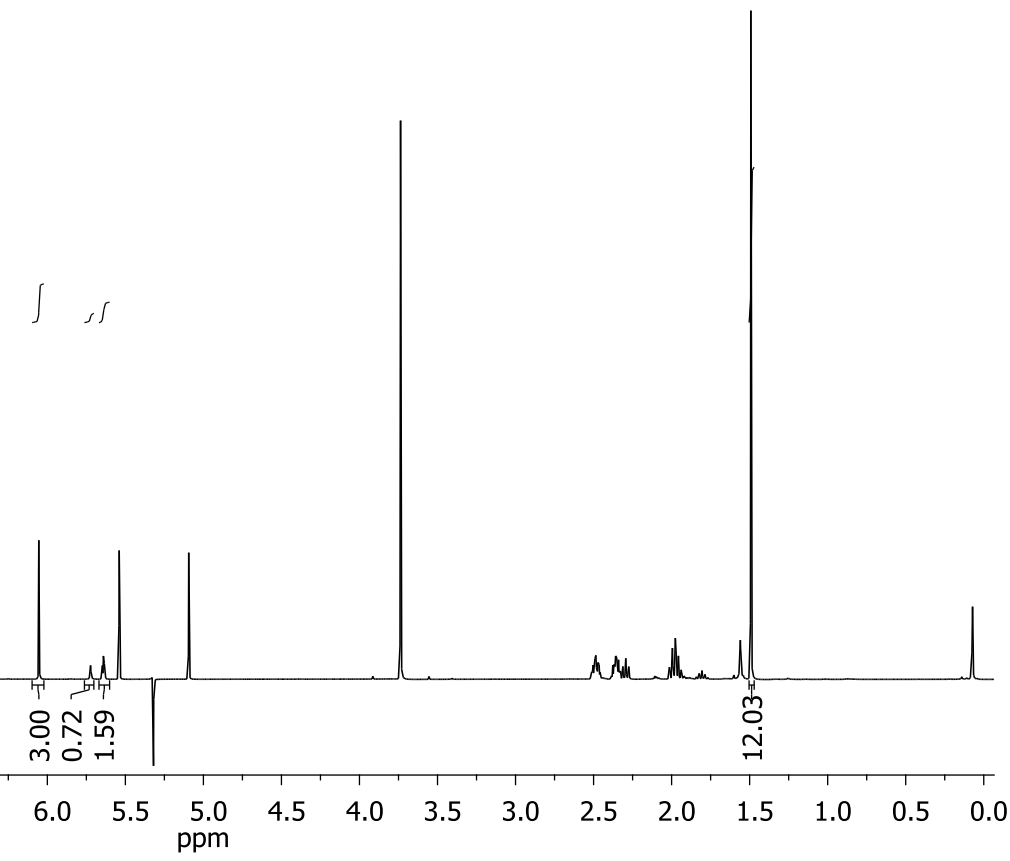

1-chlorocyclopentene reduction - CARBON

23.0mg 1,3,5-trimethoxybenzene

$\mathrm{CH} 2 \mathrm{Cl} 2$<smiles>ClC1CCCC1</smiles>

$2 k$

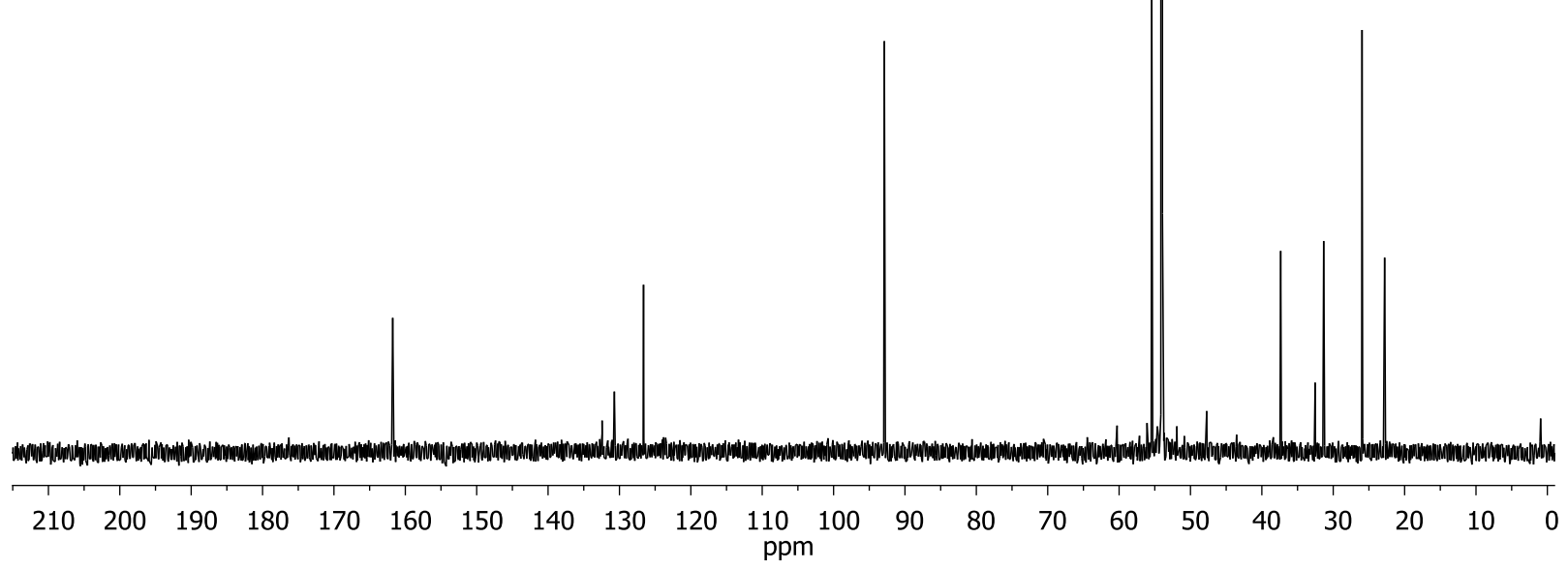


Terpineol reduction - PROTON

$\mathrm{CDCl} 3$

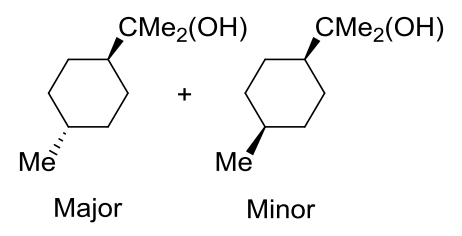

21
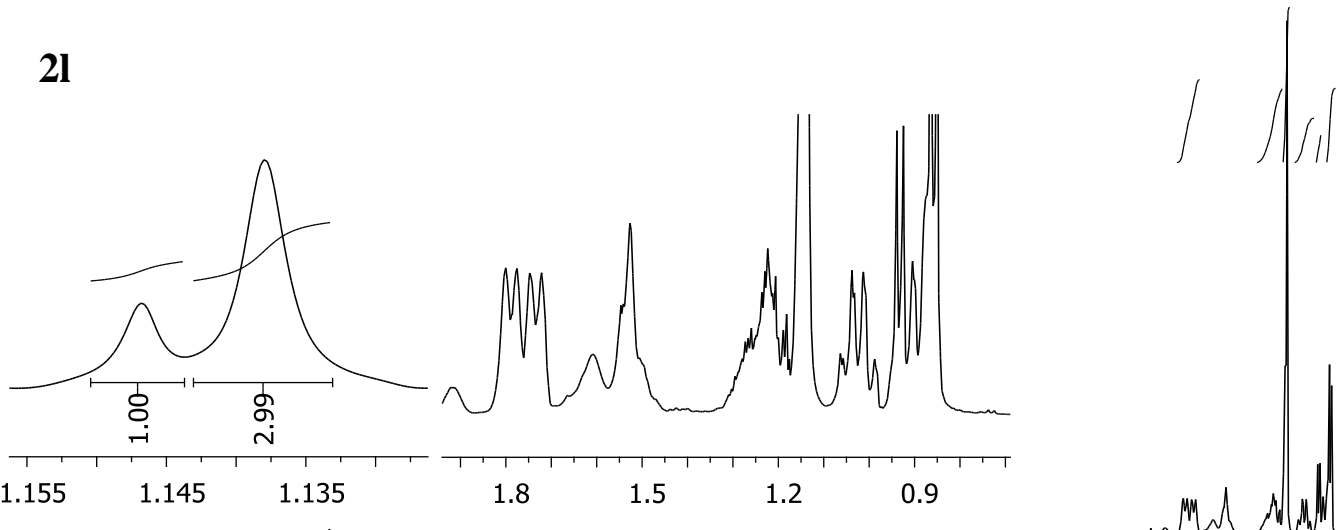

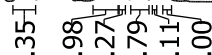

m गें ज्ञ
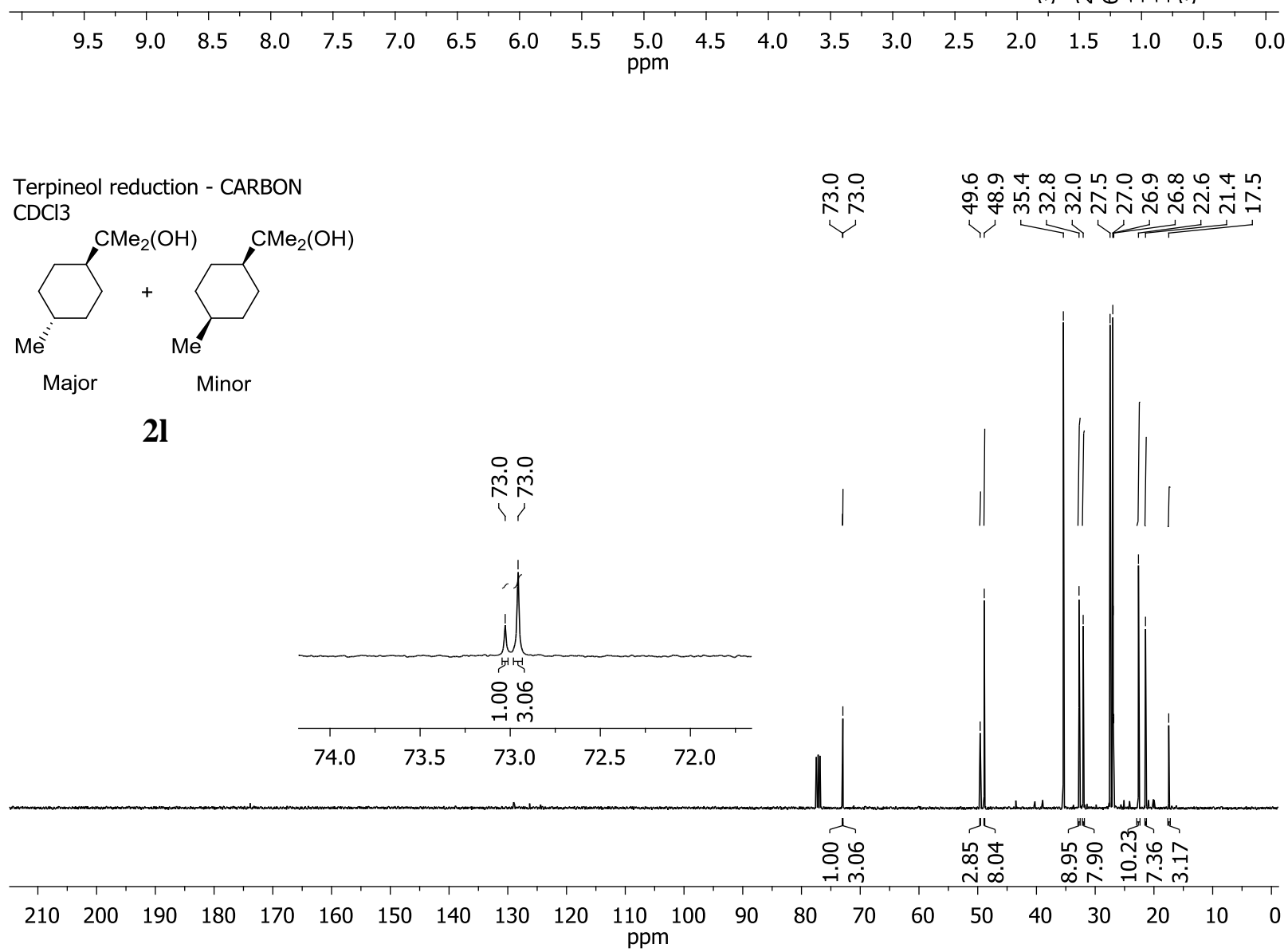
ethyl cinnamate - PROTON

$\mathrm{CDCl} 3$
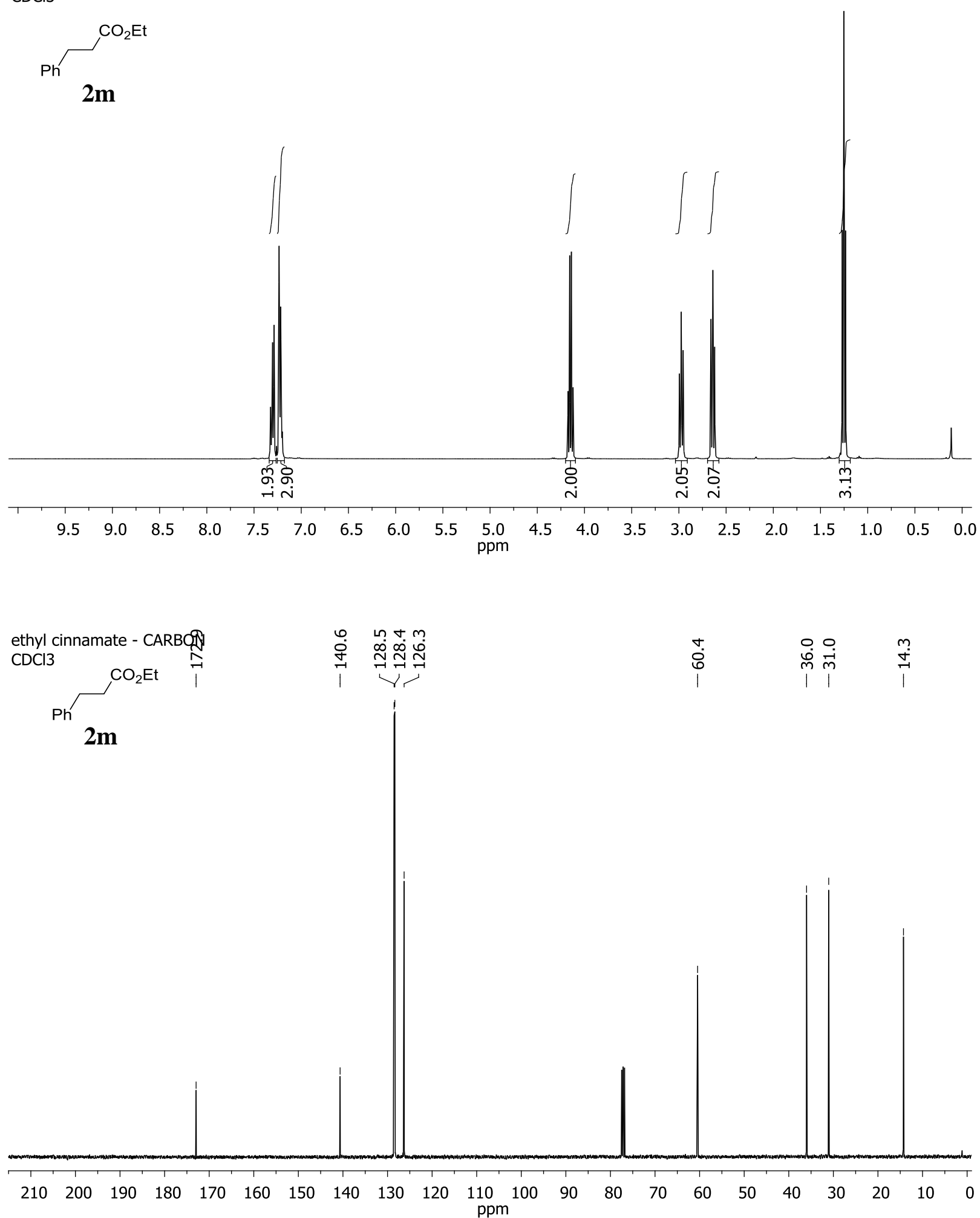
Cinnamyl Alcohol - Proton

$30.1 \mathrm{mg}$ 1,3,5-trimethoxybenzene standard

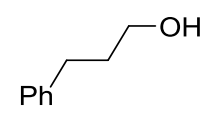

2n
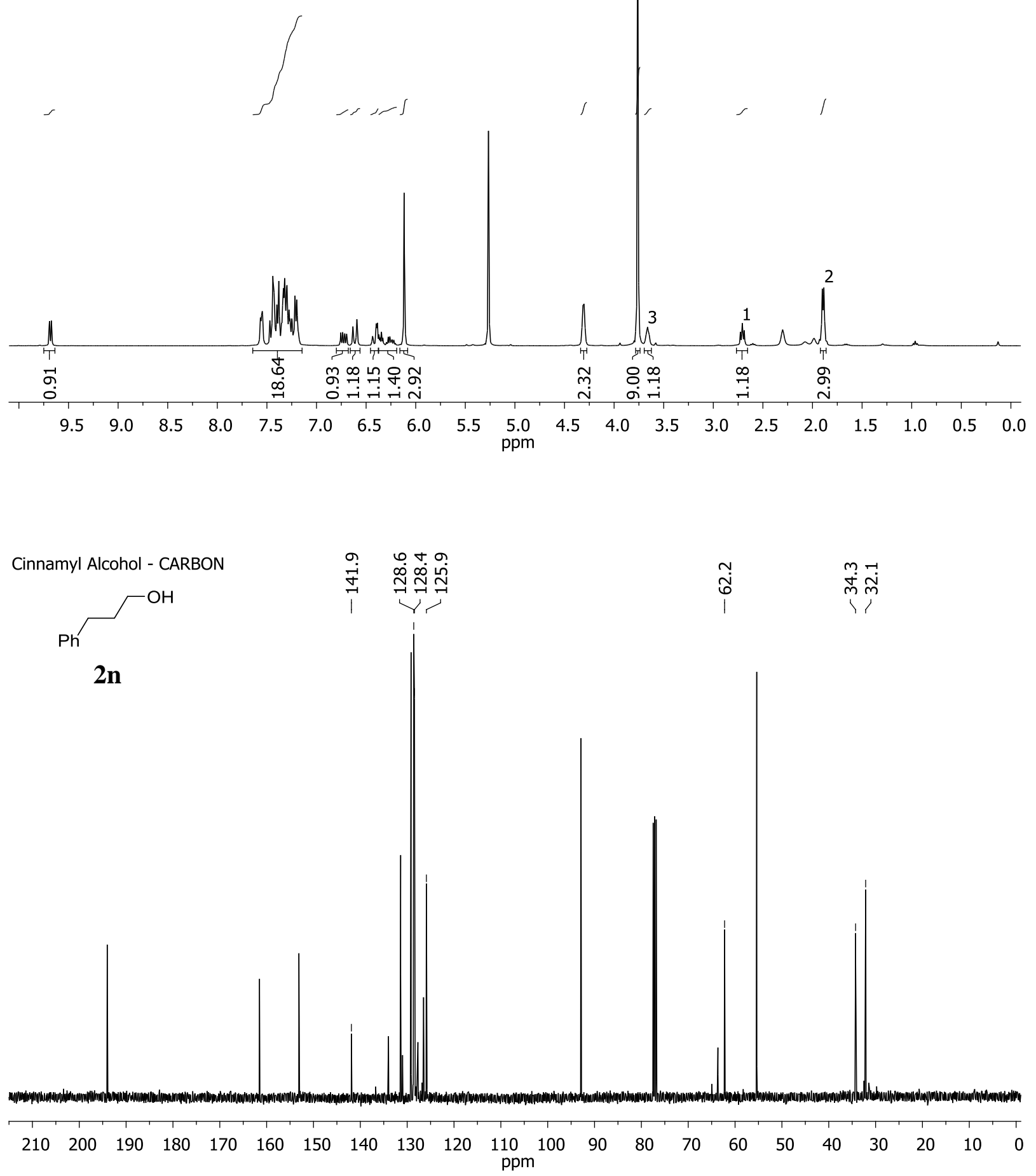
Benzyl cinnamyl ether - PROTON

$\mathrm{CH} 2 \mathrm{Cl} 2$
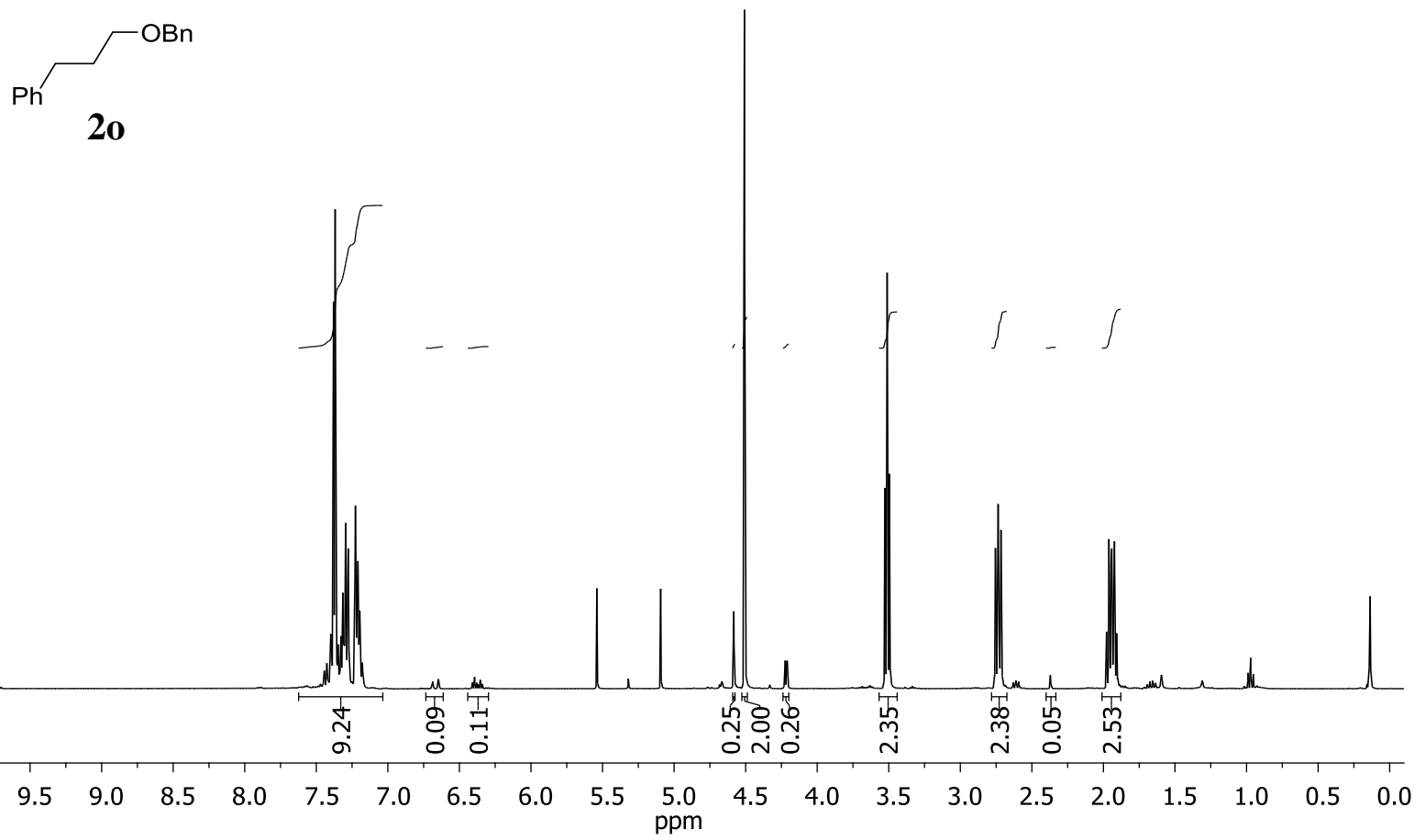

Benzyl cinnamyl ether - CARBON $\mathrm{CH} 2 \mathrm{Cl} 2$ OBn

부잉 ปั

लํํํ

11

। 1

กิ่

$\mathrm{Ph}^{20}$

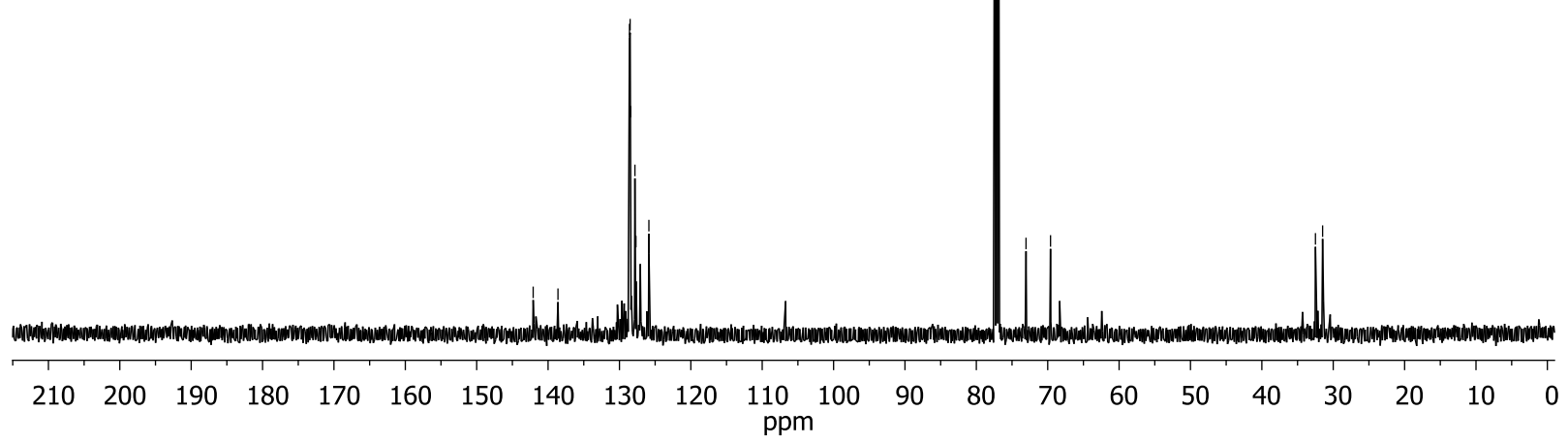



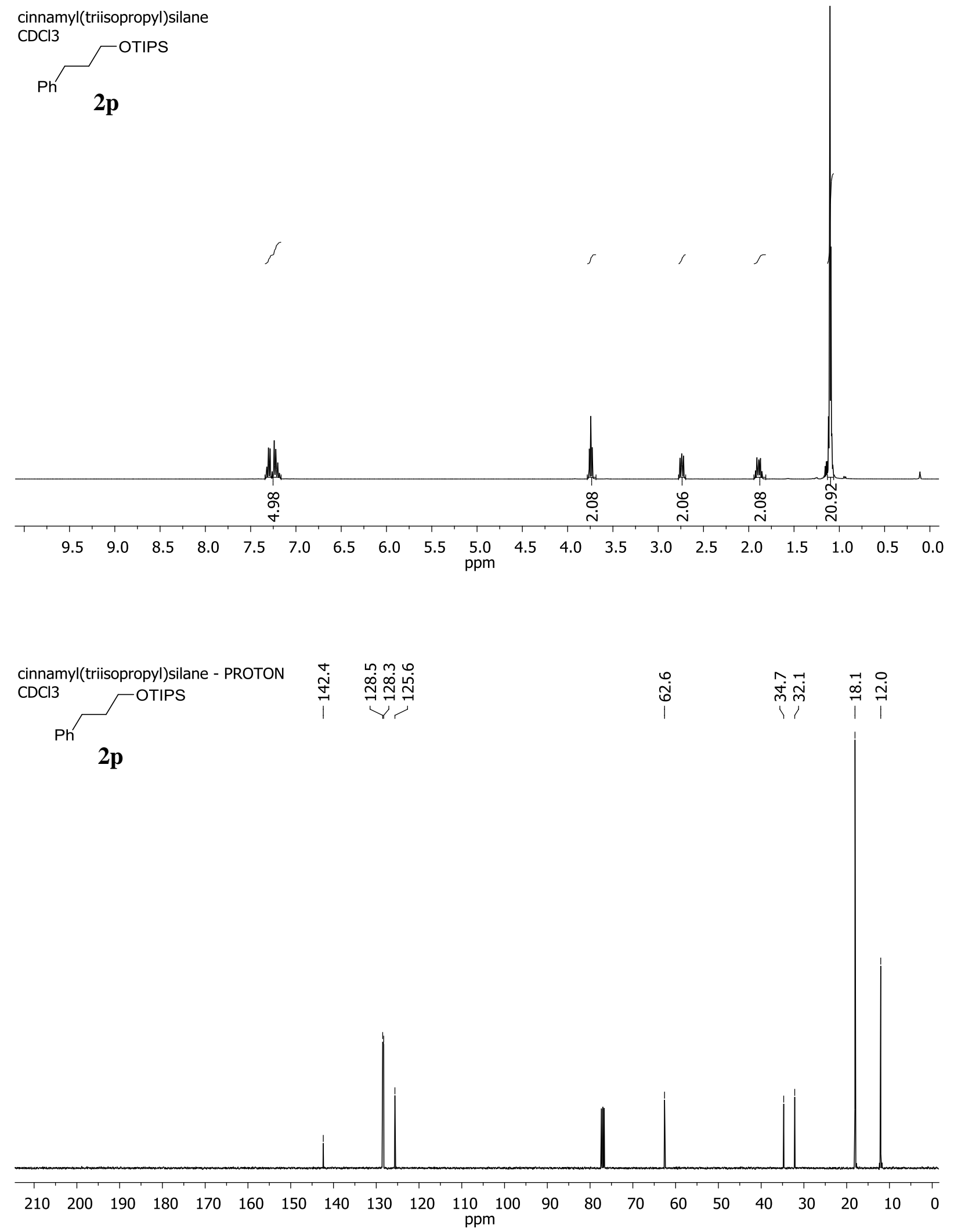
trans-stilbene - PROTON

$\mathrm{CH} 2 \mathrm{Cl} 2$
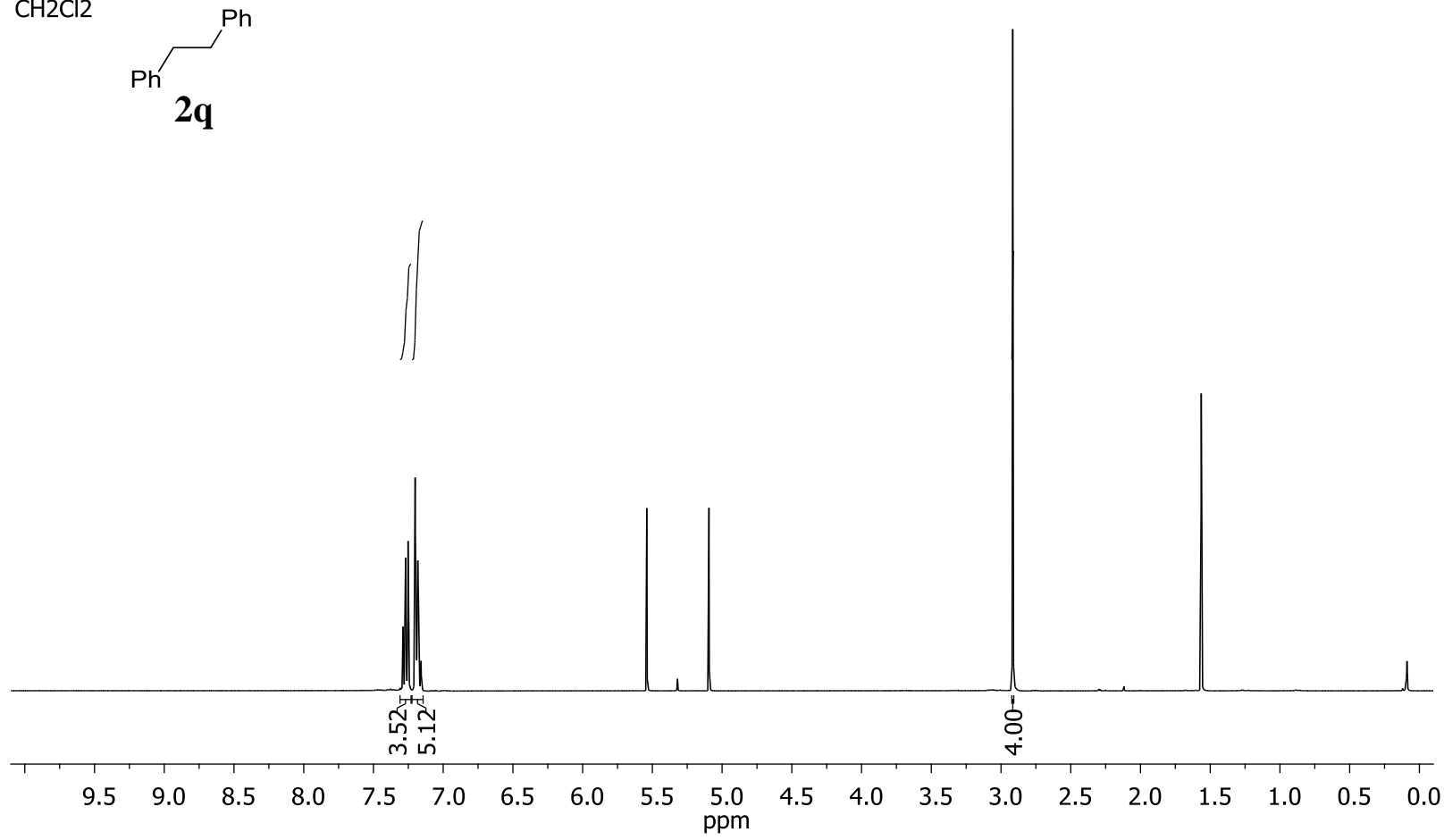

trans-stilbene - CARBON $\mathrm{CH} 2 \mathrm{Cl} 2$

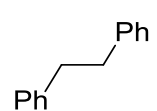

옥

2q

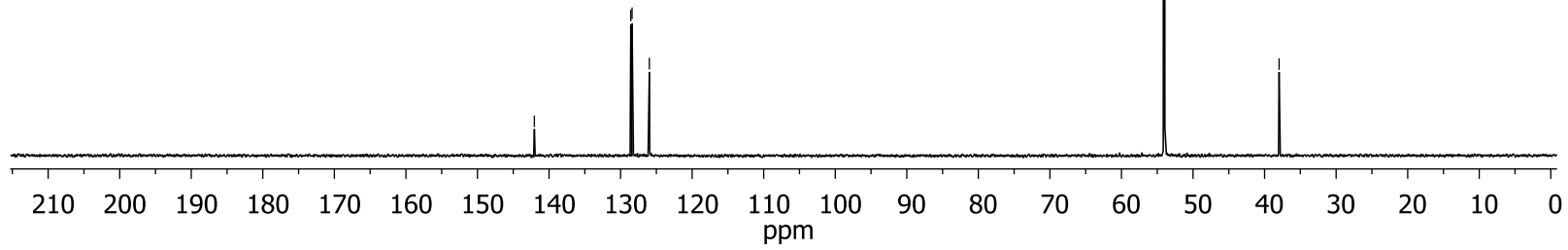



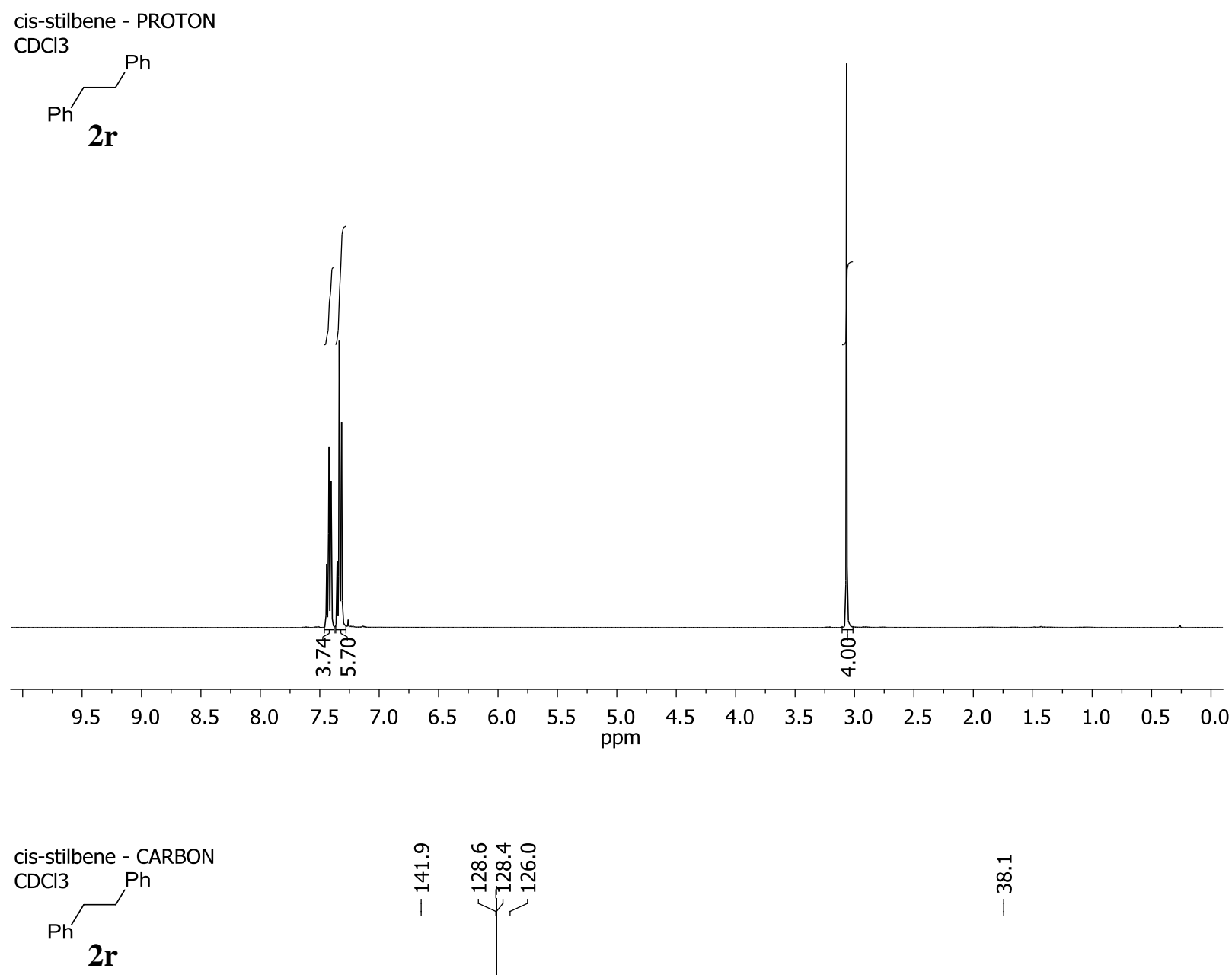

$\stackrel{-1}{m}$

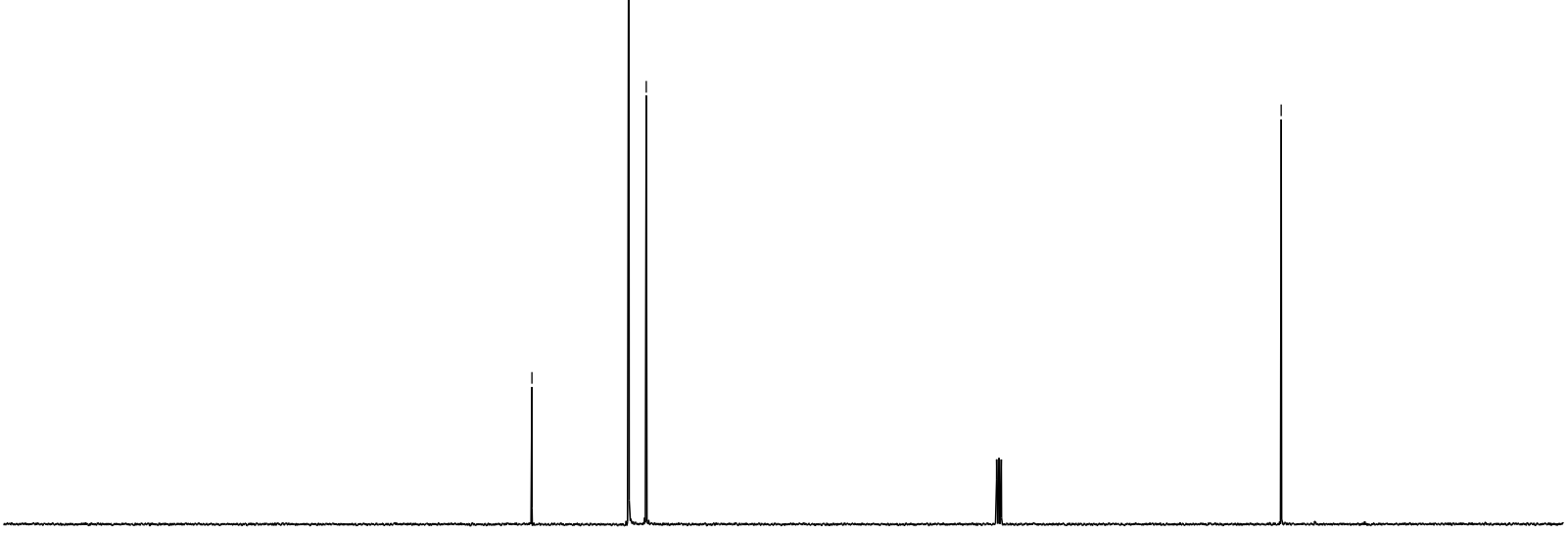

$\begin{array}{llllllllllllllllllllll}210 & 200 & 190 & 180 & 170 & 160 & 150 & 140 & 130 & 120 & \underset{\mathrm{ppm}}{110} & 100 & 90 & 80 & 70 & 60 & 50 & 40 & 30 & 20 & 10 & 0\end{array}$


trans-1-phenyl-3,3-dimethyl-1-butene - PROTON $\mathrm{CDCl} 3$<smiles>CC(C)(C)CCc1ccccc1</smiles>
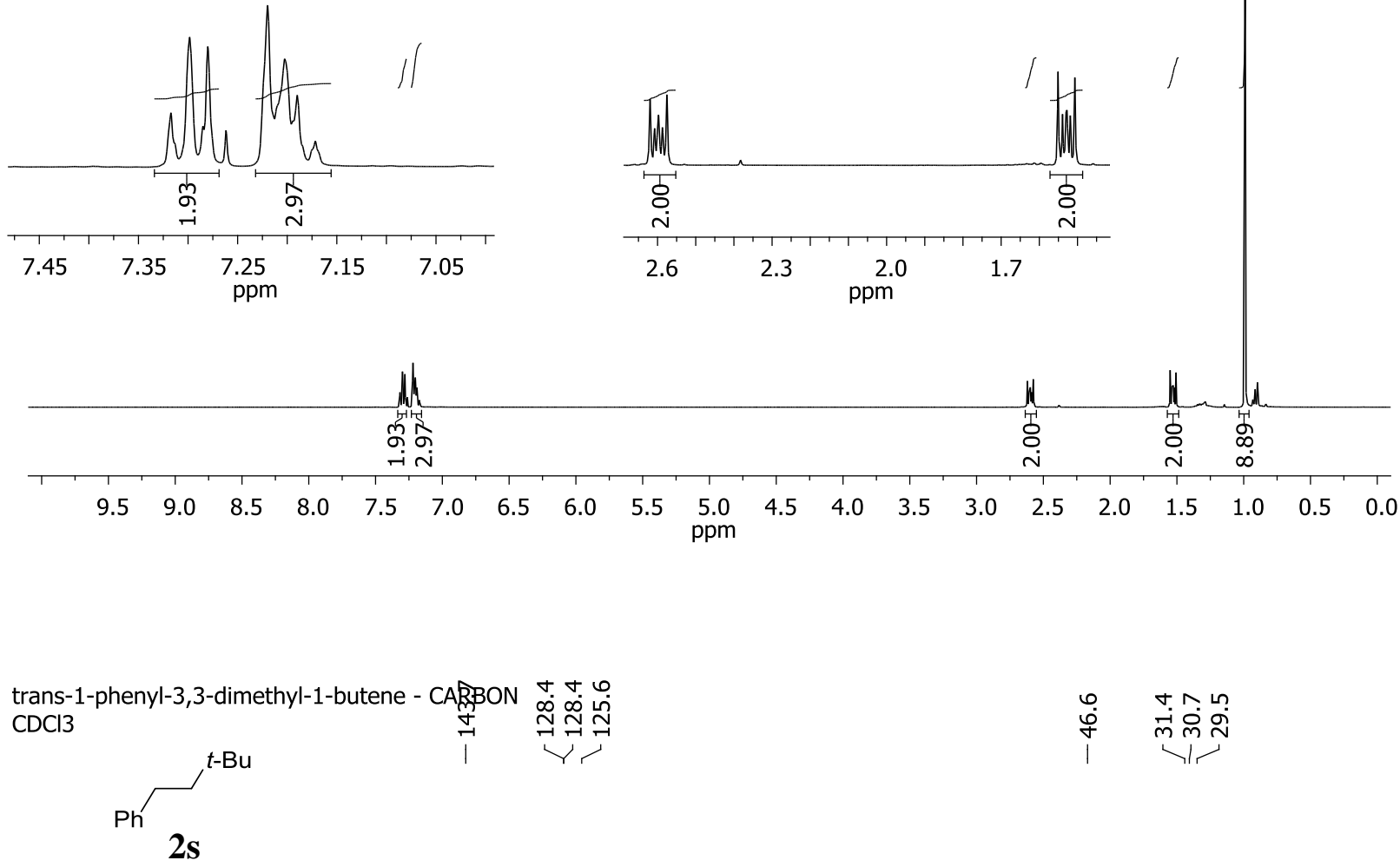

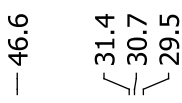

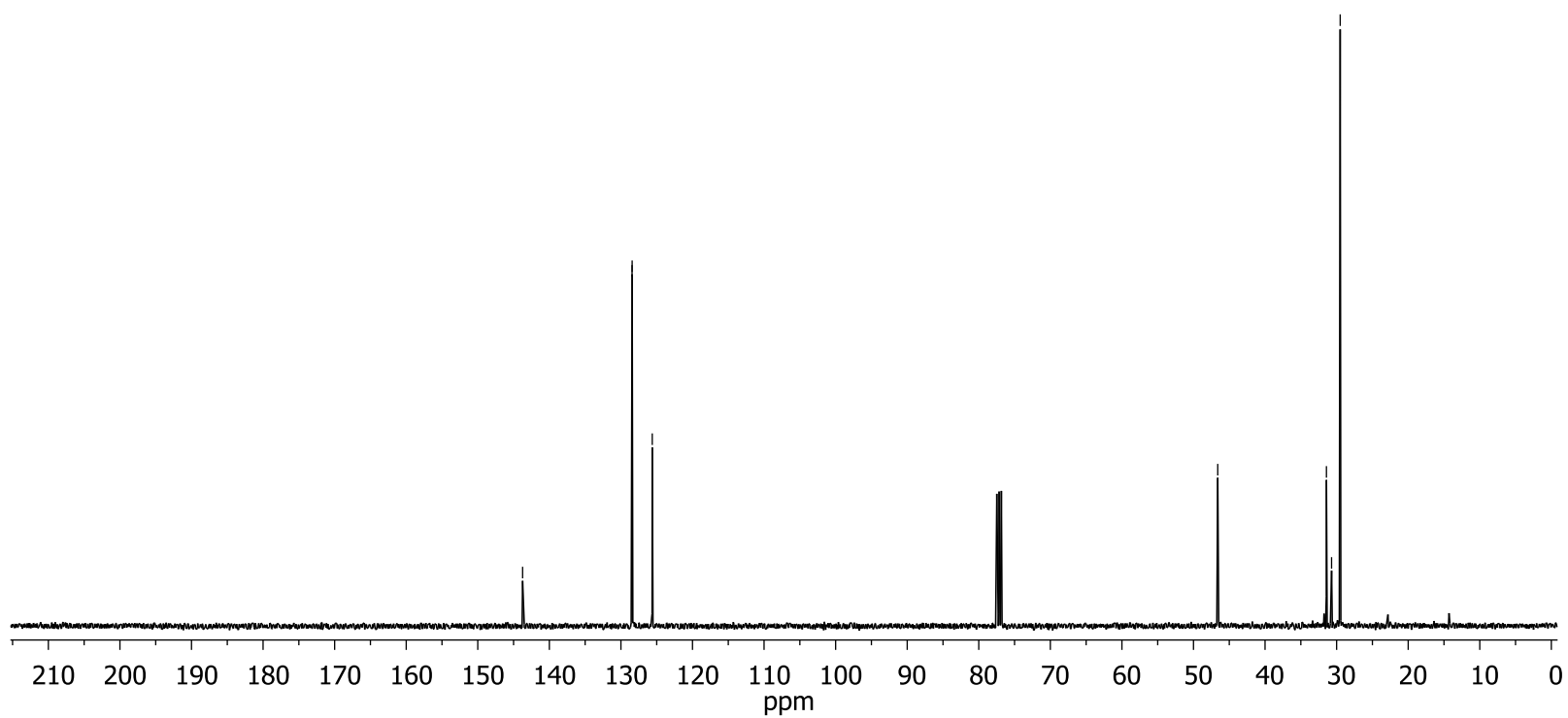


alpha-methylstilbene - PROTON

$\mathrm{CDCl} 3$<smiles>CC(Cc1ccccc1)c1ccccc1</smiles>

$2 \mathbf{t}$

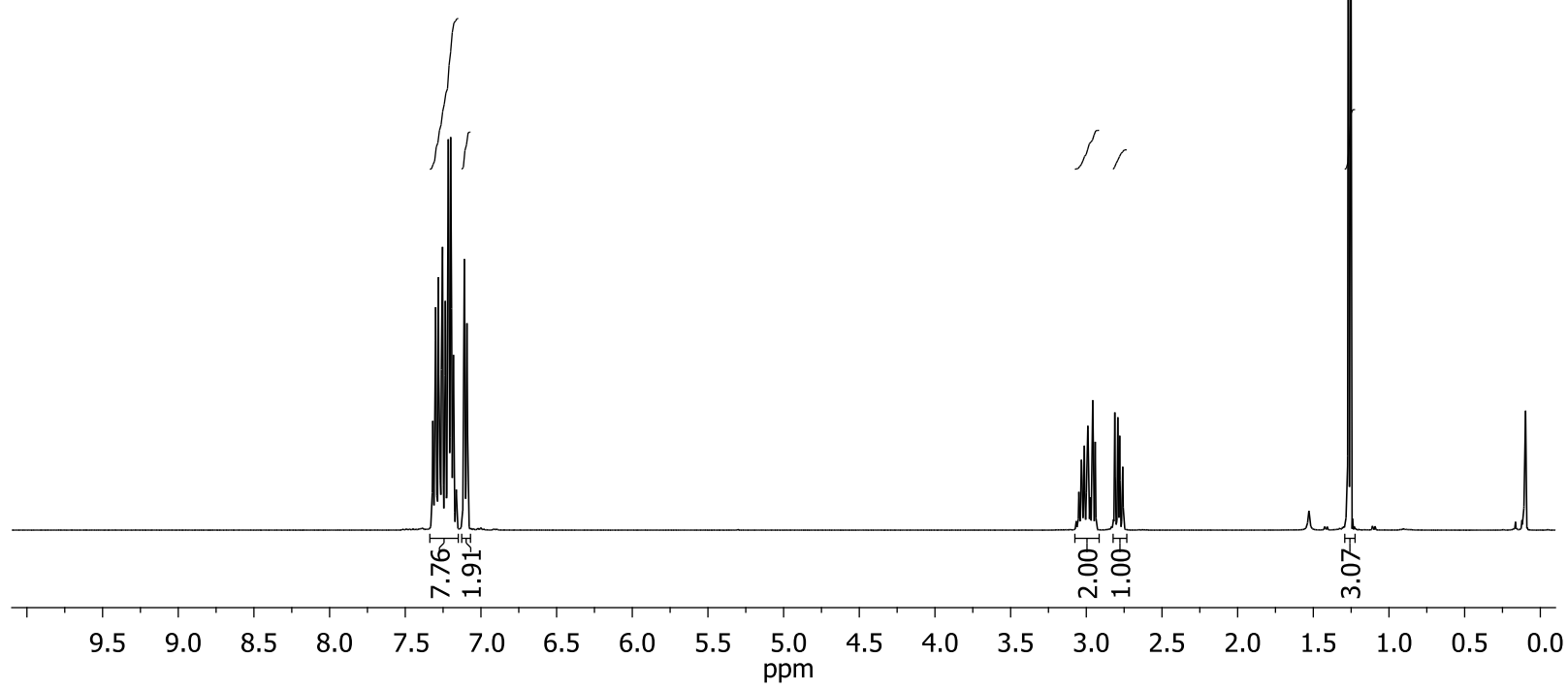

alpha-methylstilbene - CARBON $\mathrm{CDCl} 3$

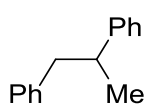

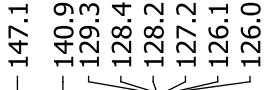

ทุ่

$2 t$

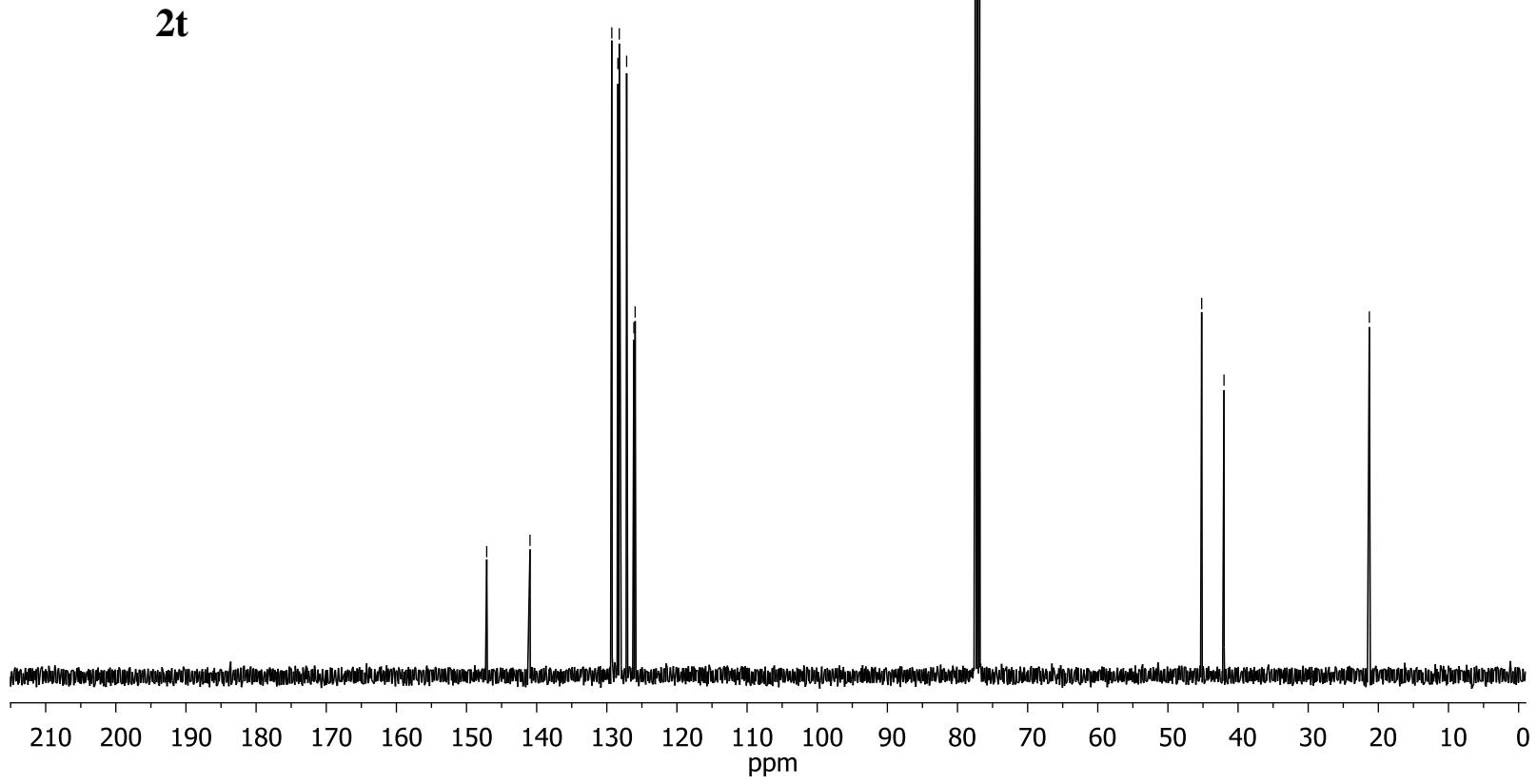


tetraphenylethene - PROTON

rxn 18 hrs; $\mathrm{CH} 2 \mathrm{Cl} 2$
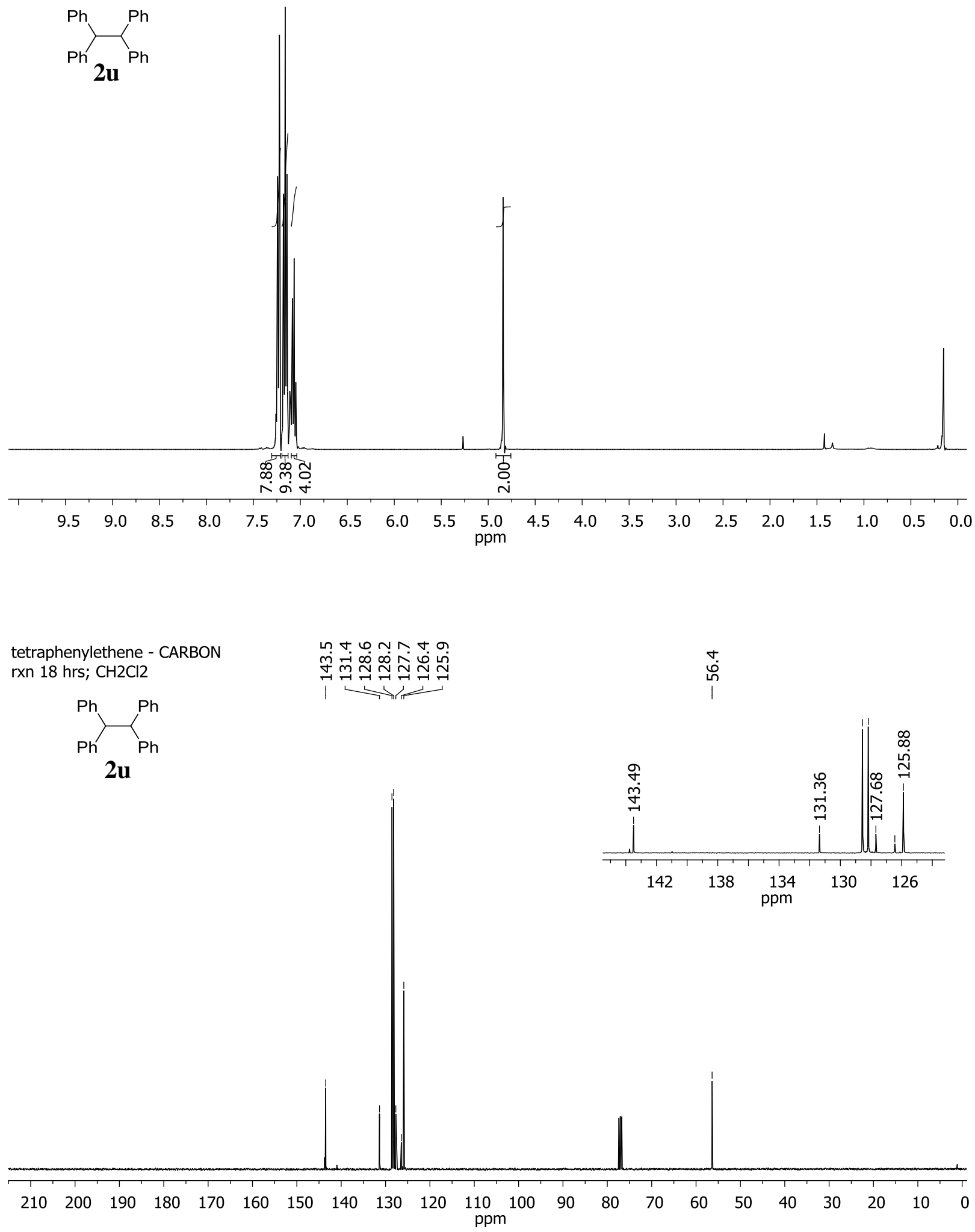

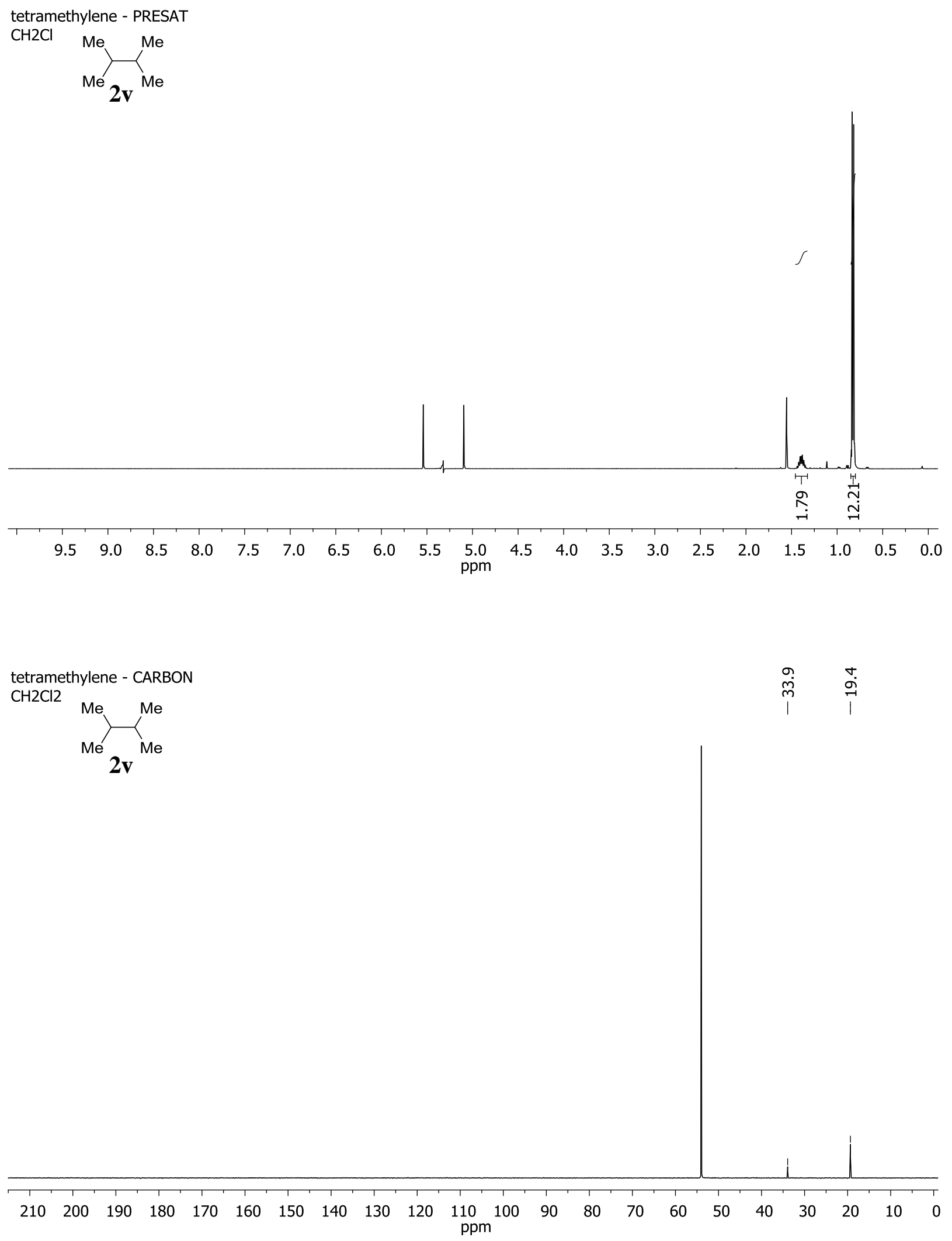

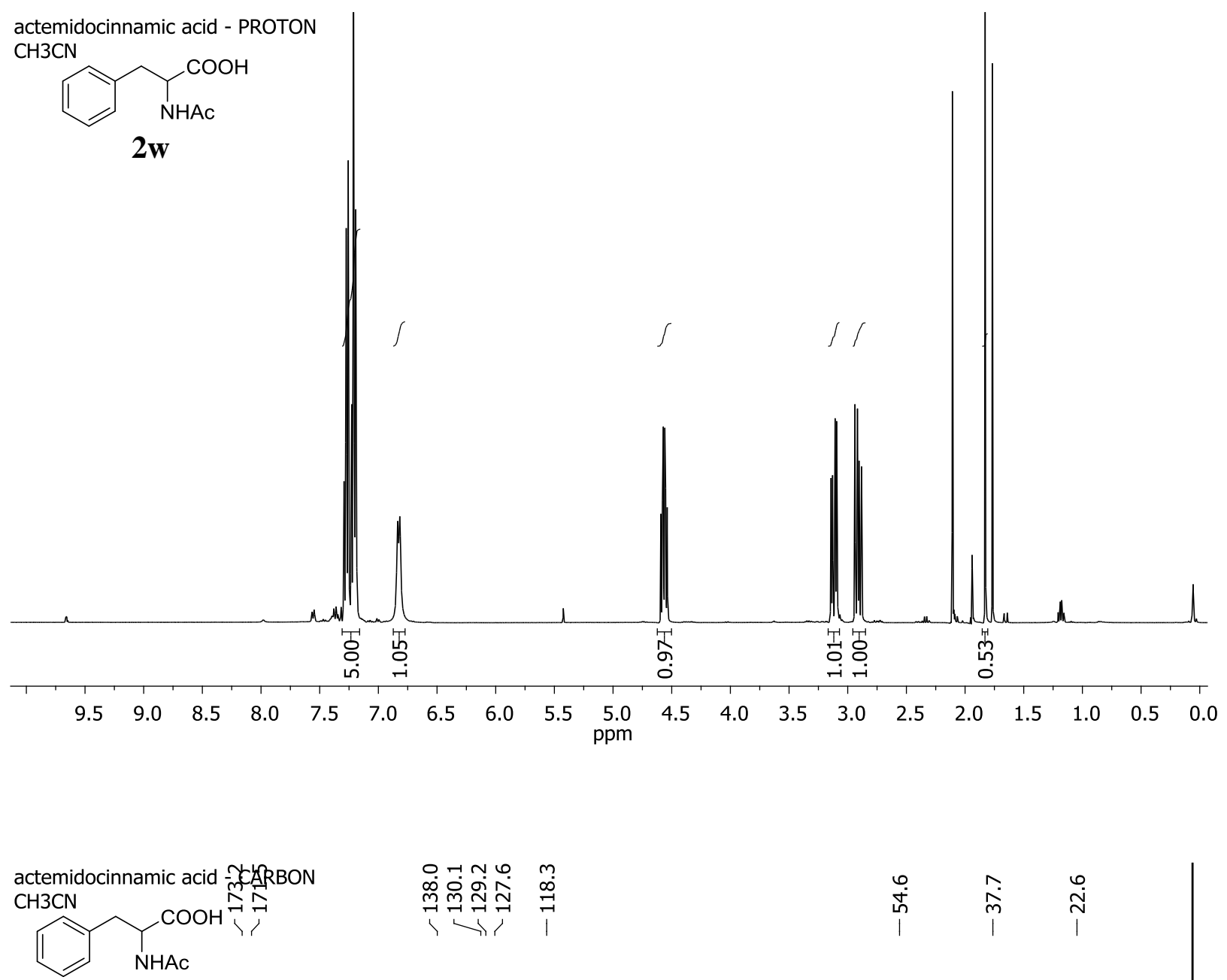

2w

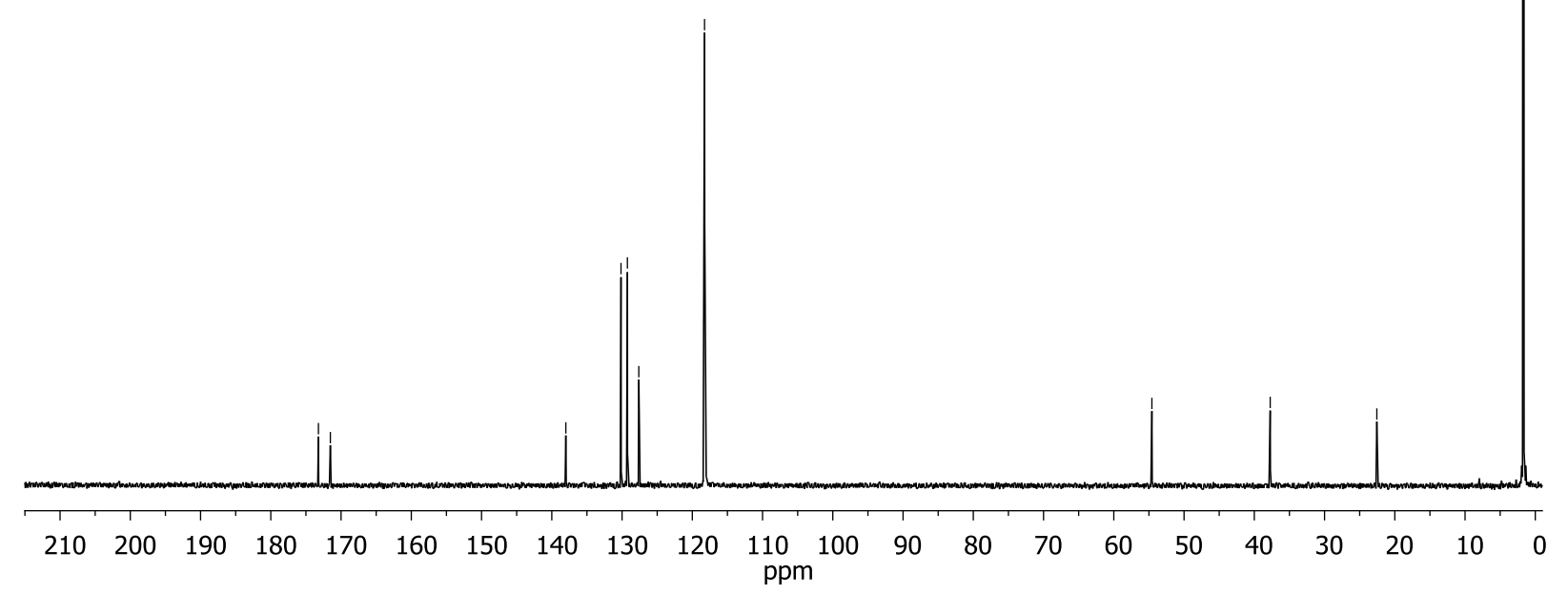


styrene - PROTON

$\mathrm{CDCl} 3$

$$
\begin{gathered}
\mathrm{C}_{6} \mathrm{H}_{5} \\
\mathbf{2 x}
\end{gathered}
$$
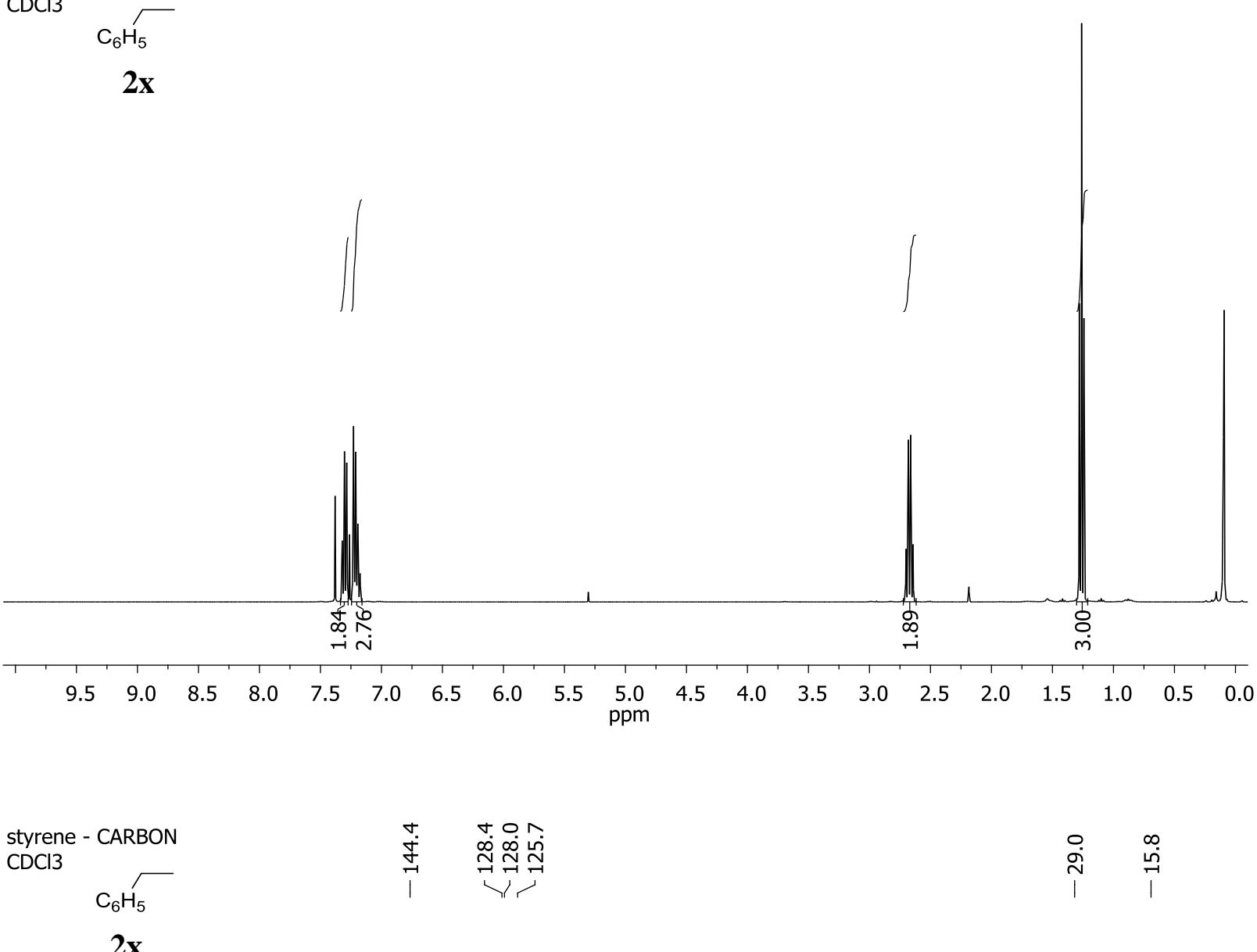

욜

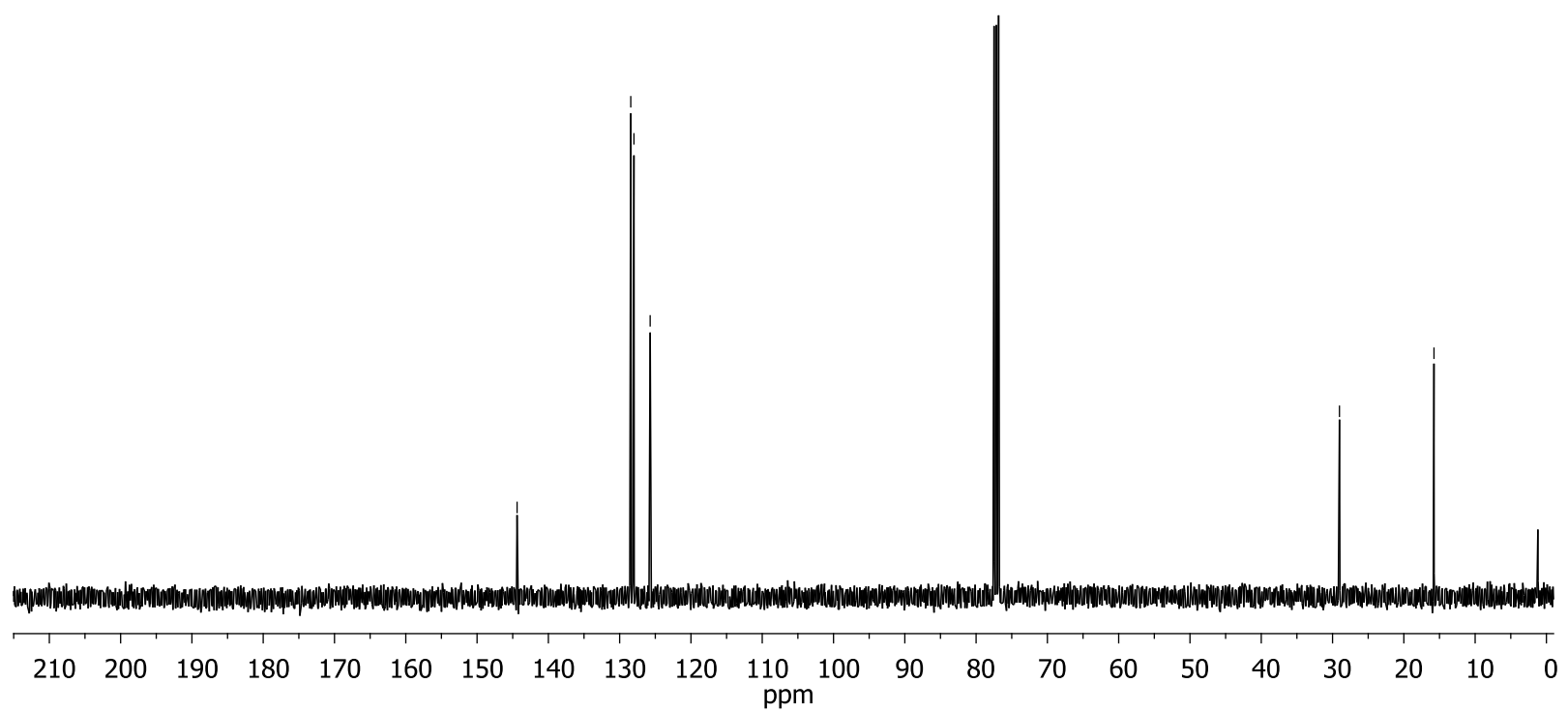


4-methoxystyrene - PROTON

$\mathrm{CDCl} 3$

$$
\underset{\mathbf{2} \mathbf{y}}{p-\mathrm{OMe}\left(\mathrm{C}_{6} \mathrm{H}_{4}\right)}
$$

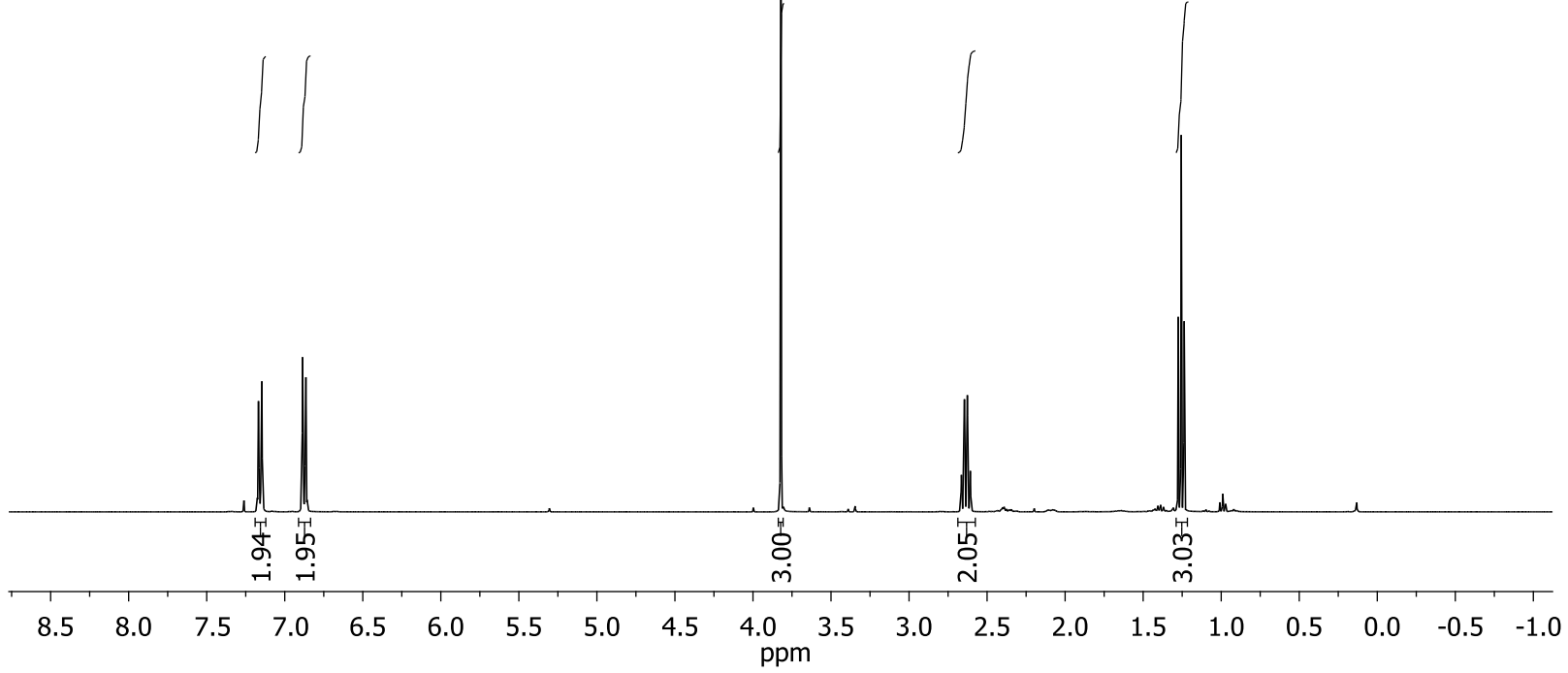
4-methoxystyrene - CARBON $\mathrm{CDCl} 3$

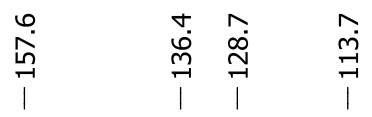

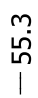

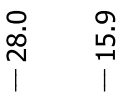

$2 y$

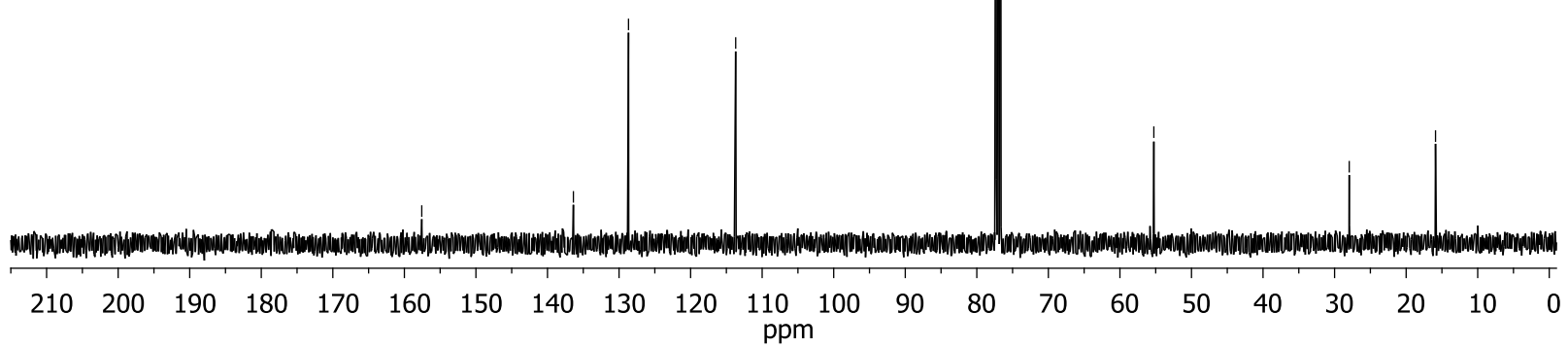



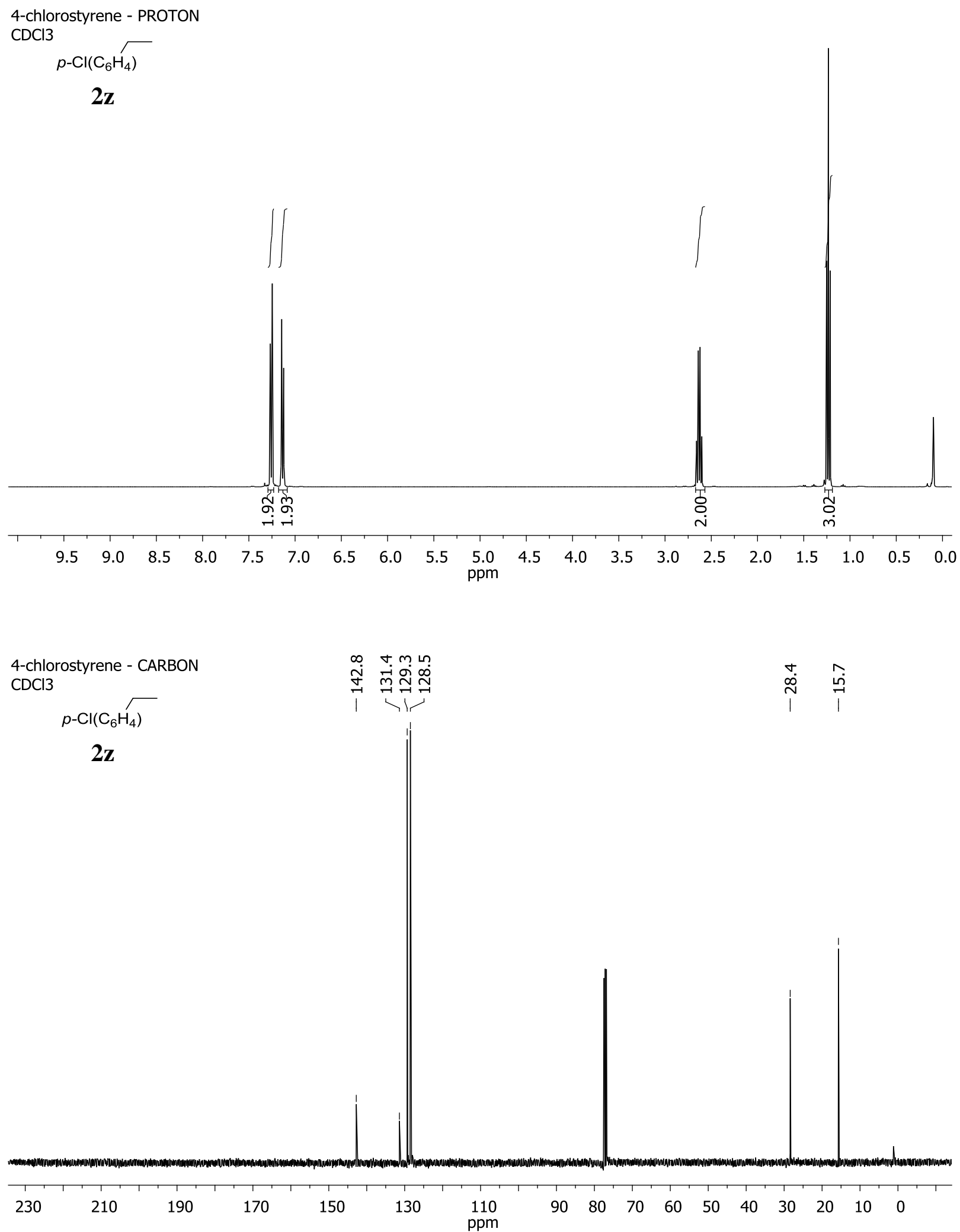
4-trifluoromethylstyrene - PROTON

$\mathrm{CDCl} 3$

$$
\begin{aligned}
& p-\mathrm{CF}_{3}\left(\mathrm{C}_{6} \mathrm{H}_{4}\right) \\
& \mathbf{2 a a}
\end{aligned}
$$
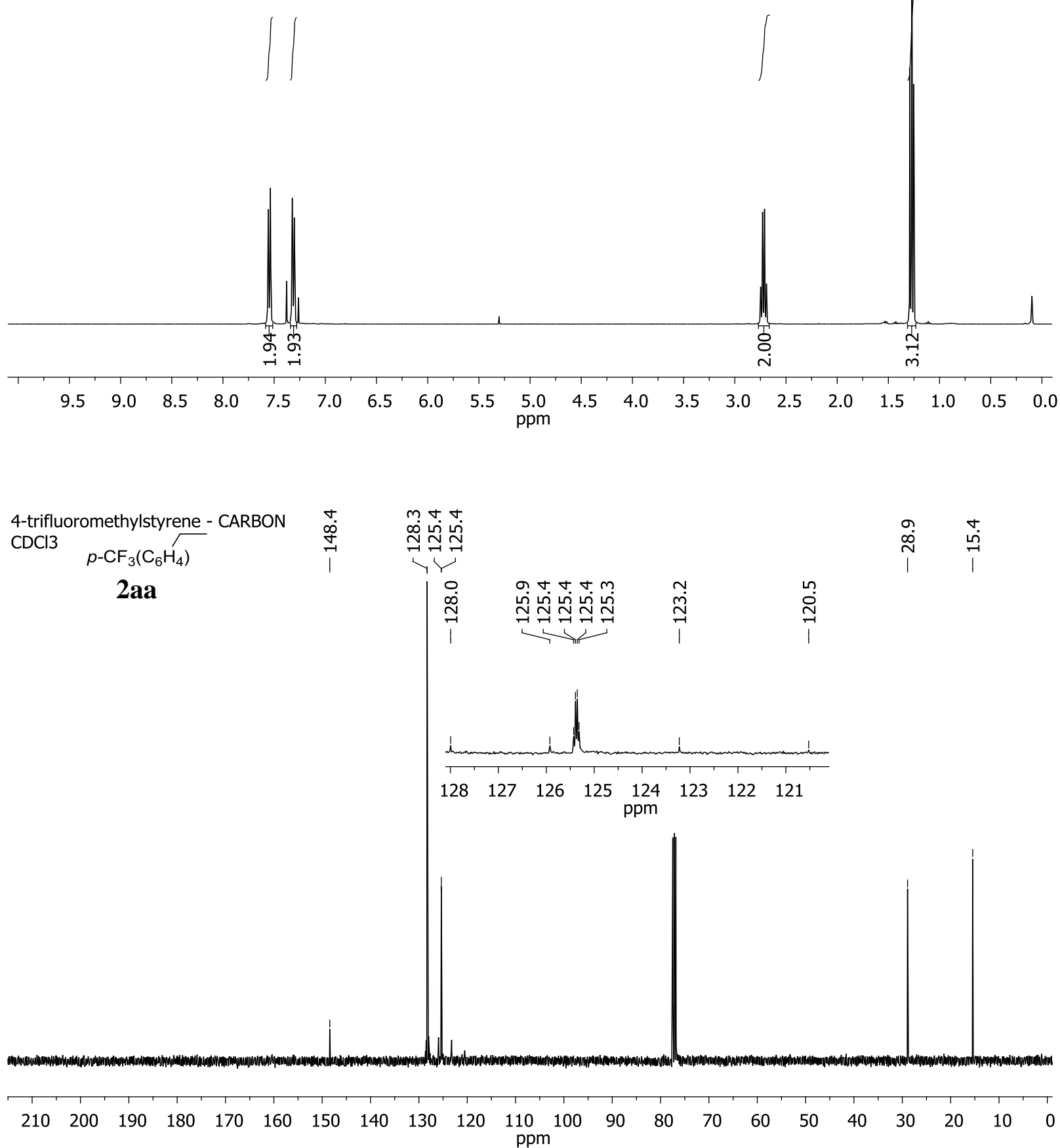

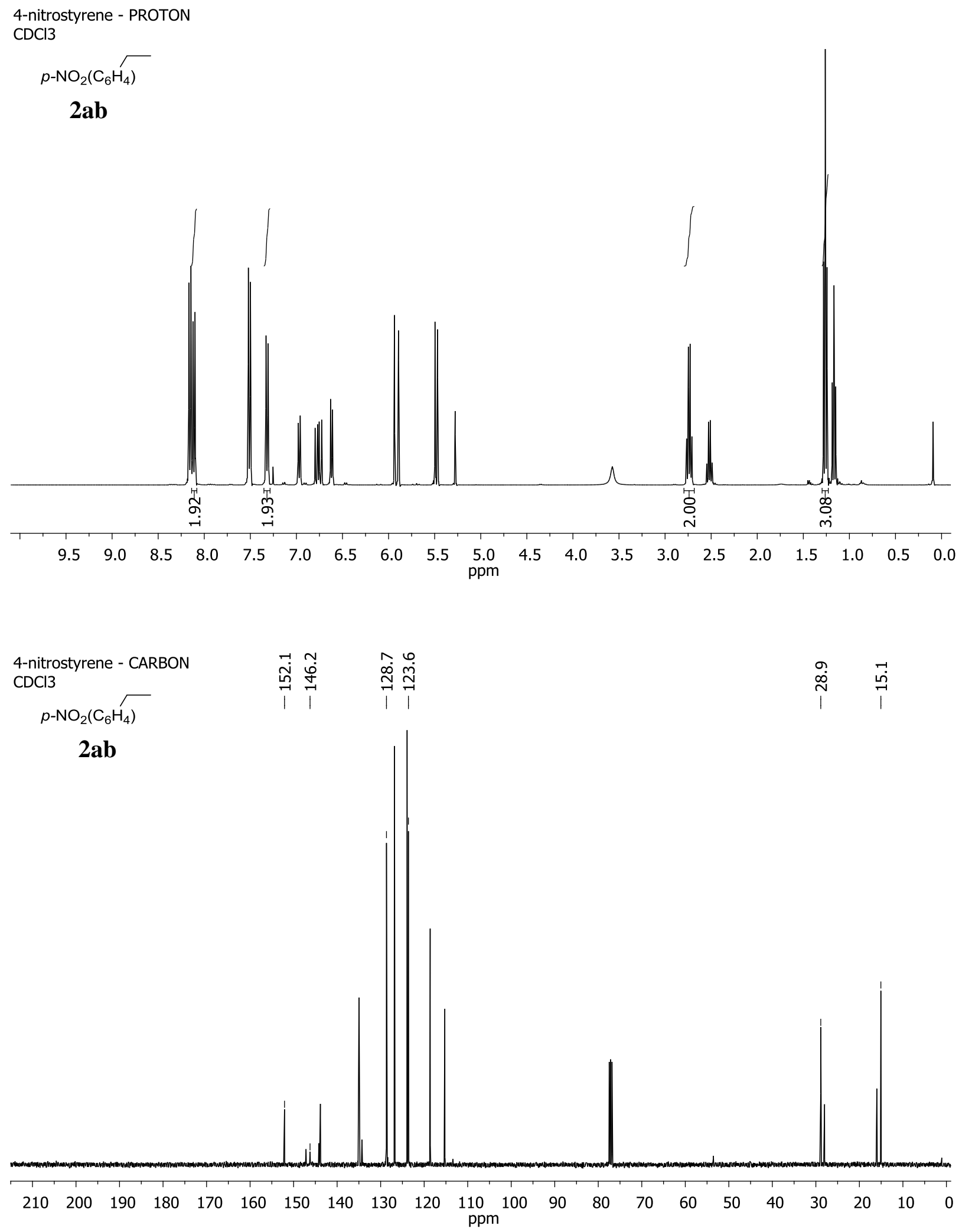

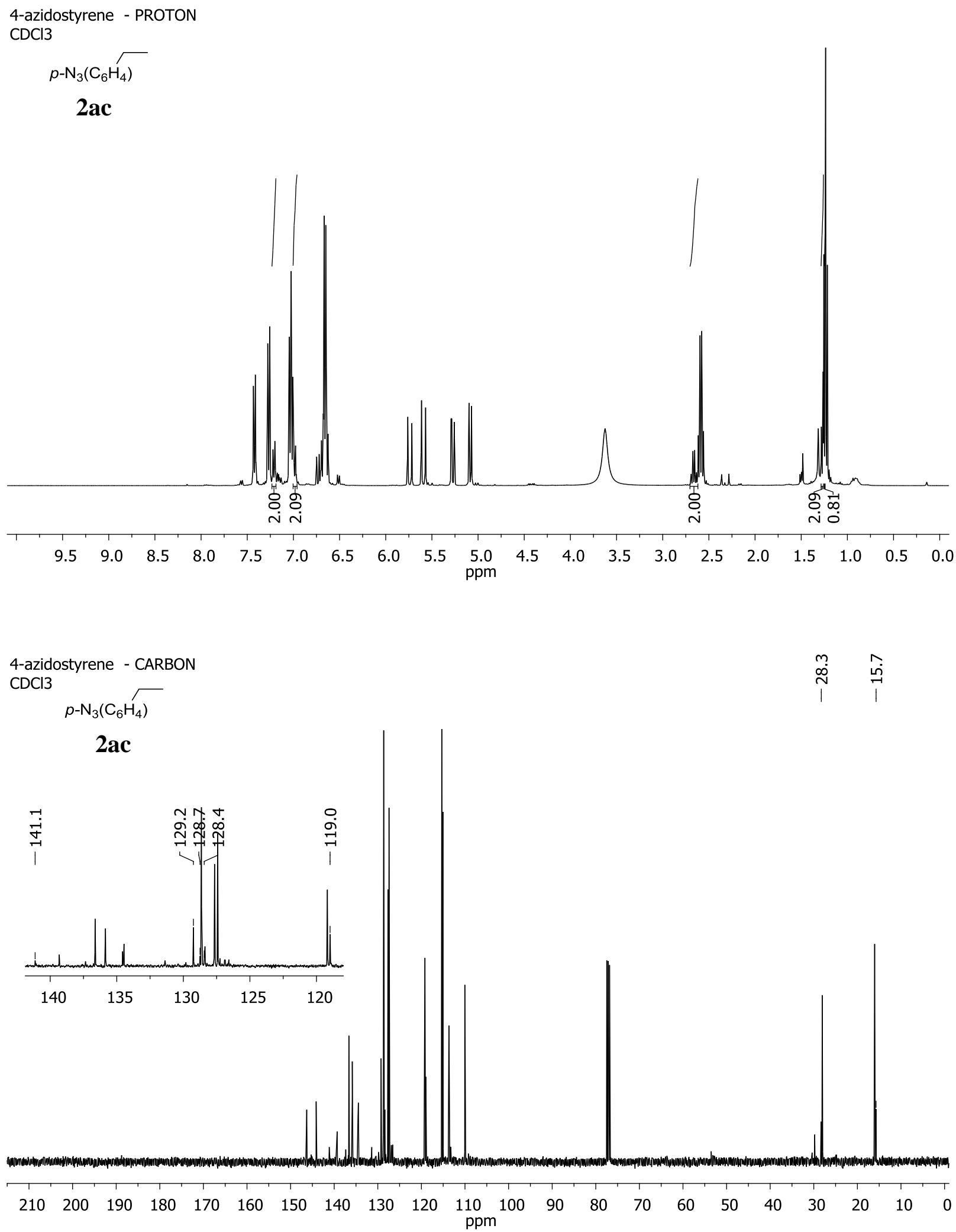

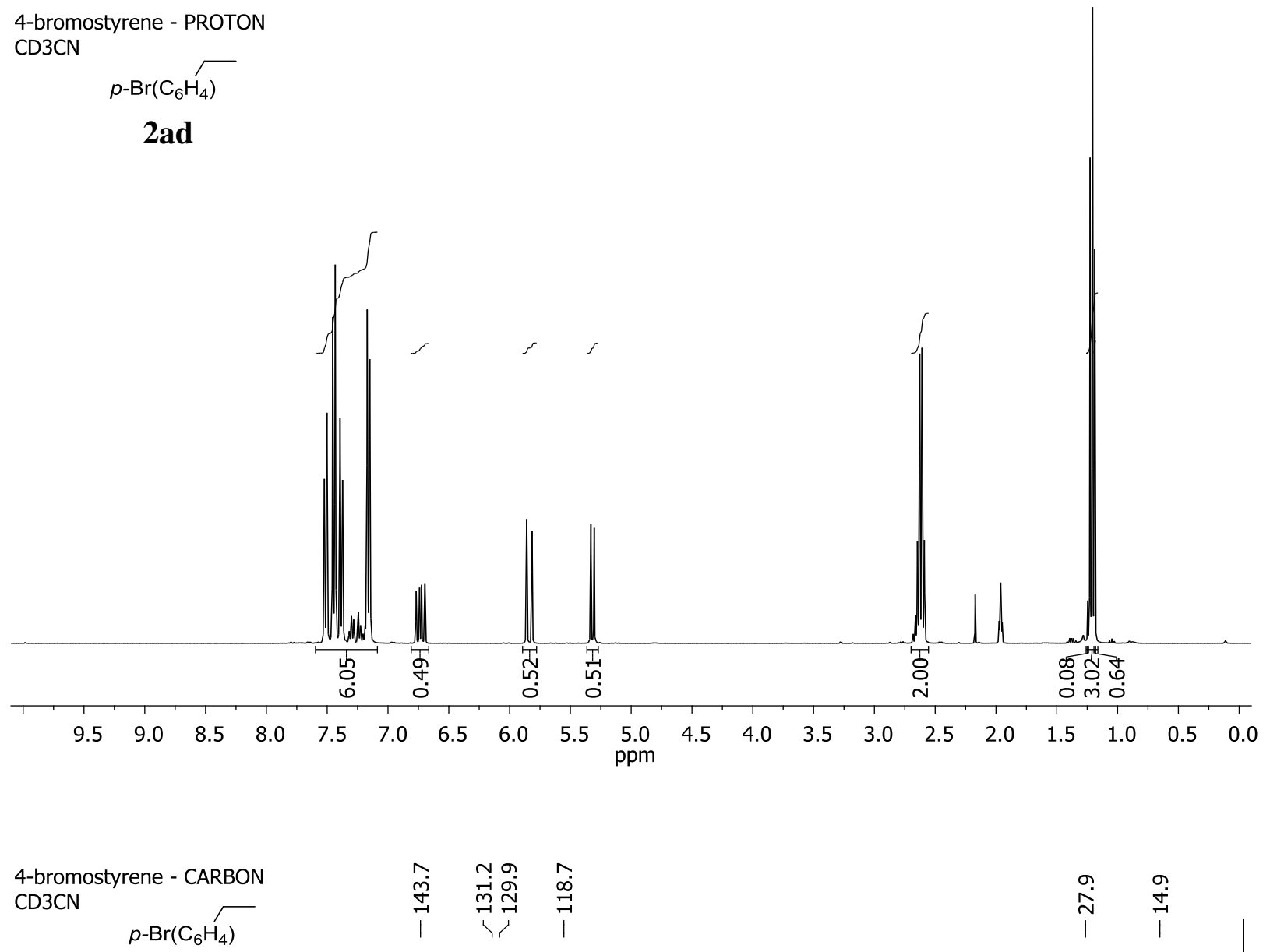

กิ

2ad

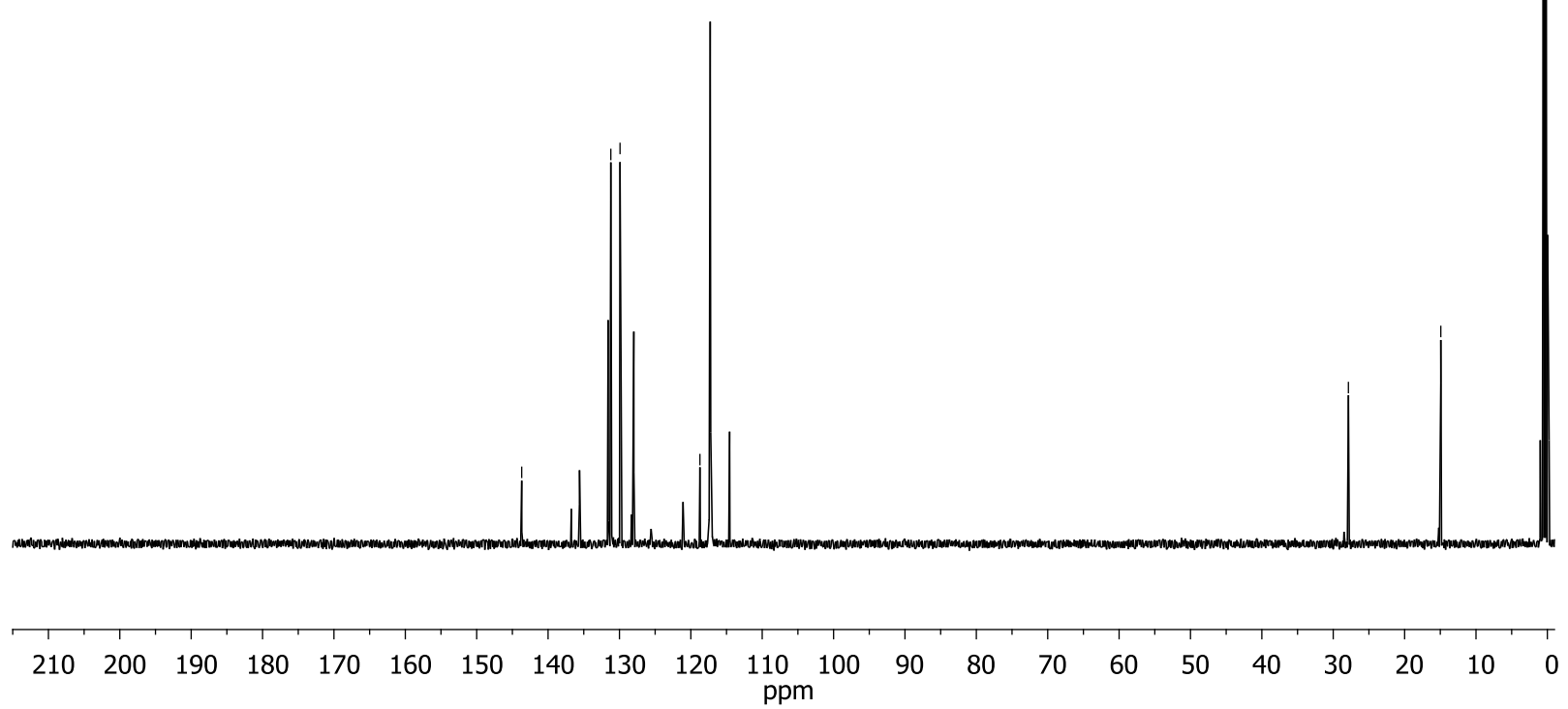




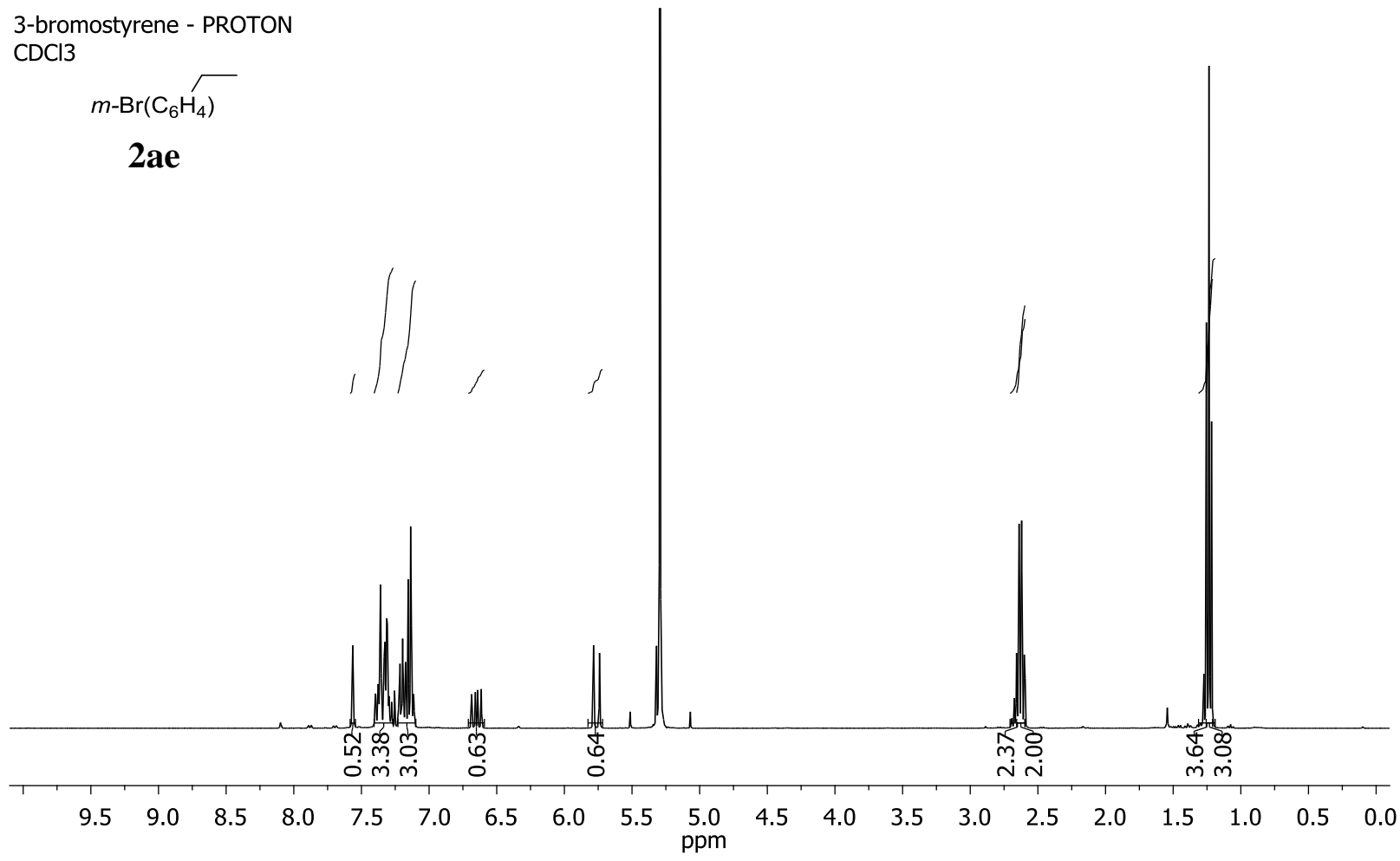

3-bromostyrene - CARBON
CDCl3
$m-\operatorname{Br}\left(\mathrm{C}_{6} \mathrm{H}_{4}\right)$

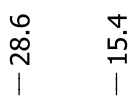

2 ae

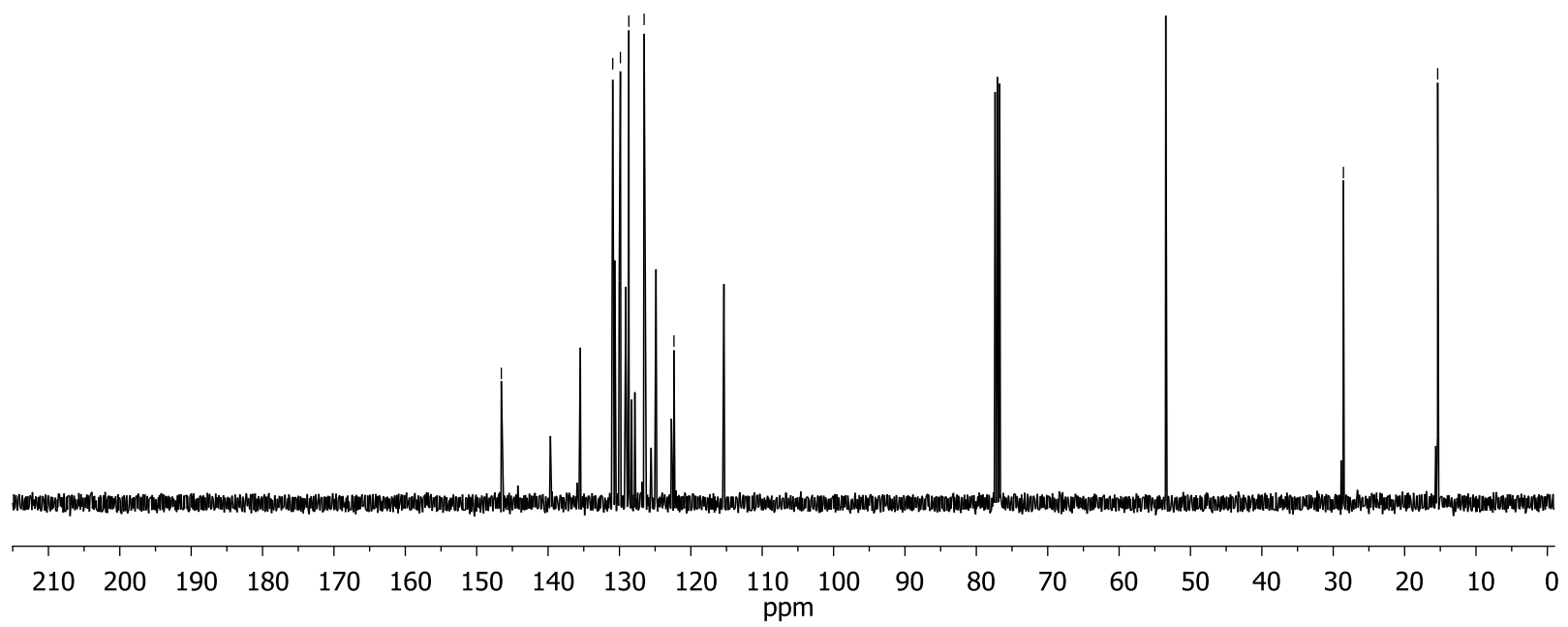



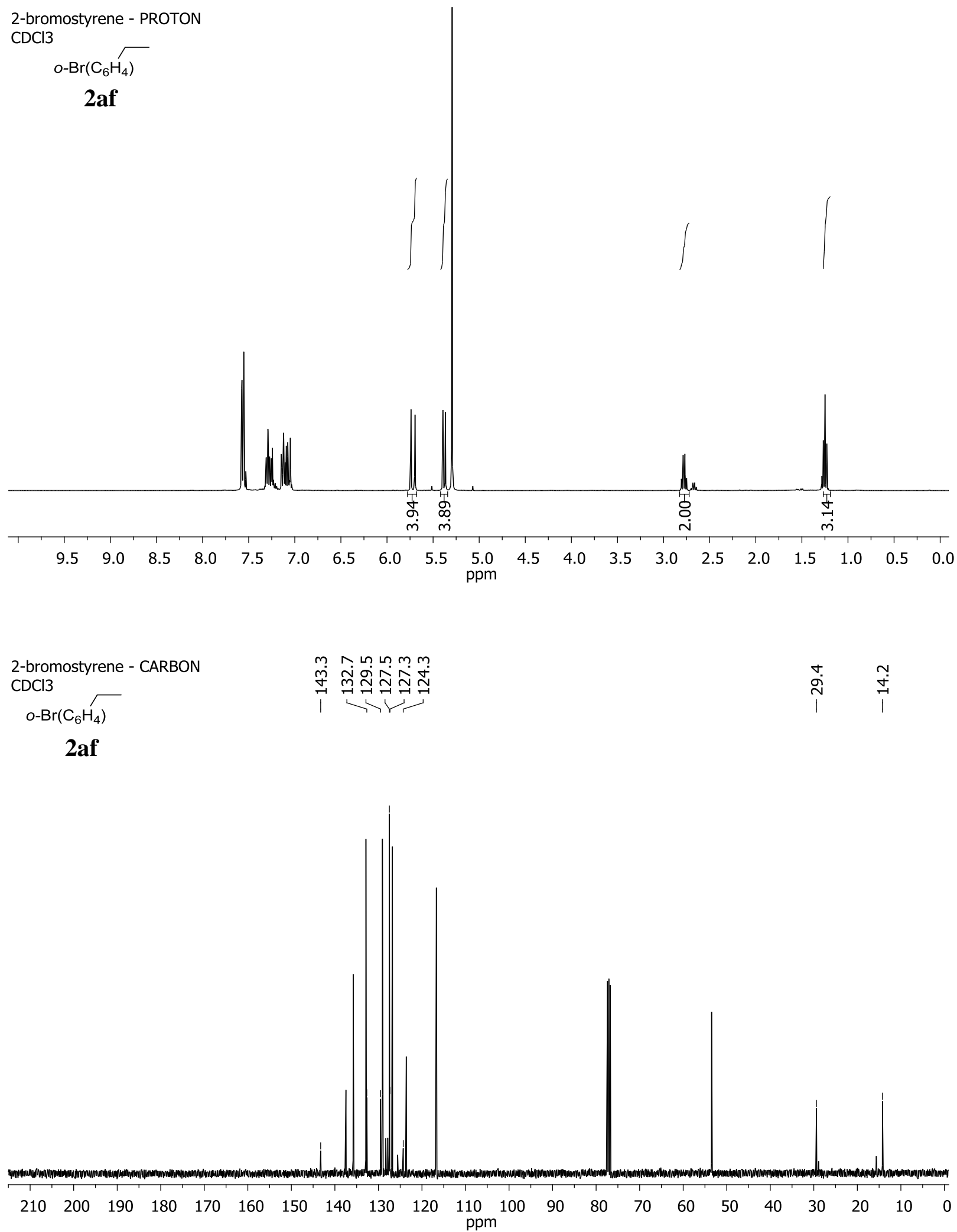
beta-bromostyrene - PROTON

$\mathrm{CH} 2 \mathrm{Cl} 2$
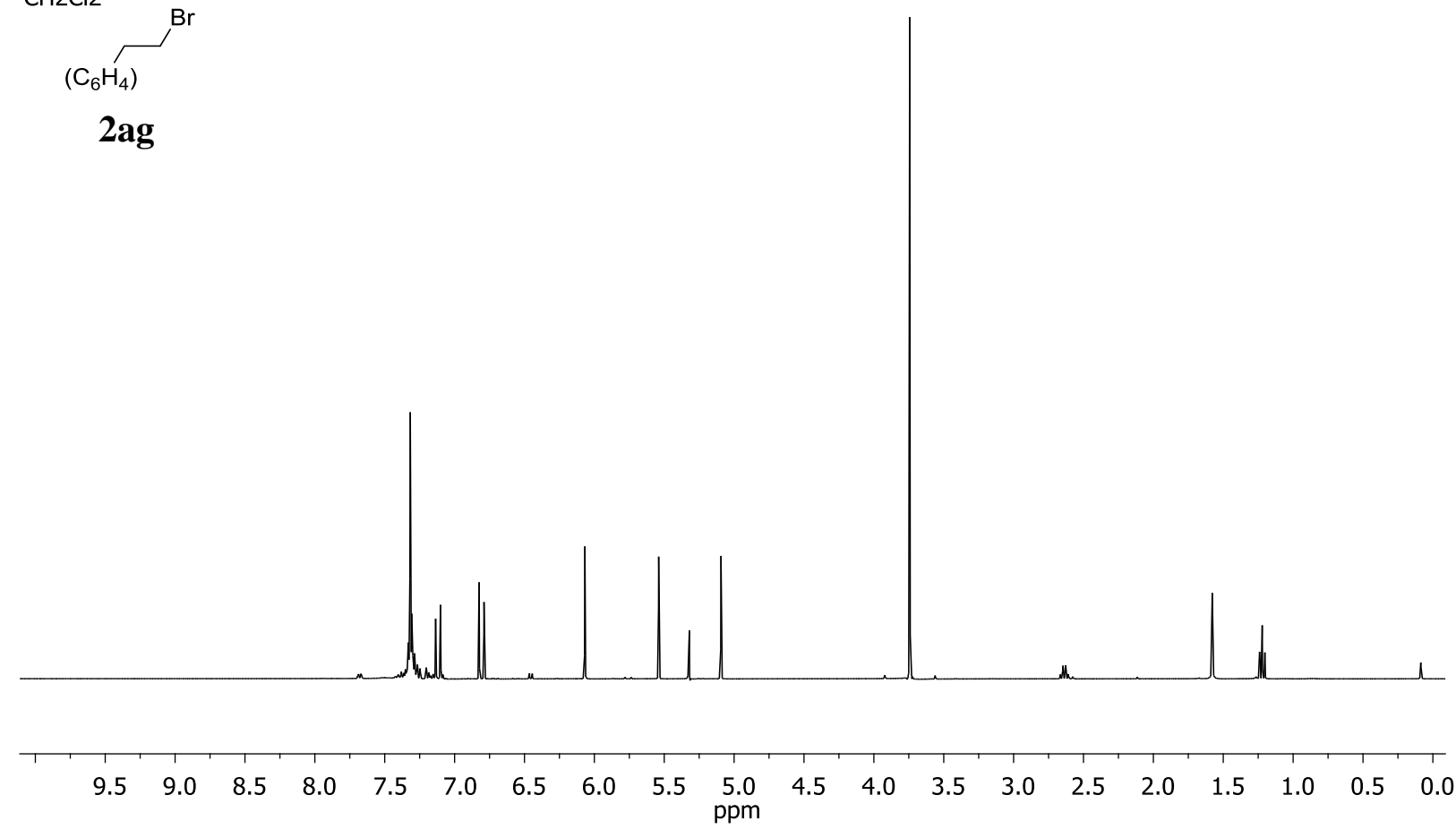

beta-bromostyrene - CARBON $\mathrm{CH} 2 \mathrm{Cl} 2$
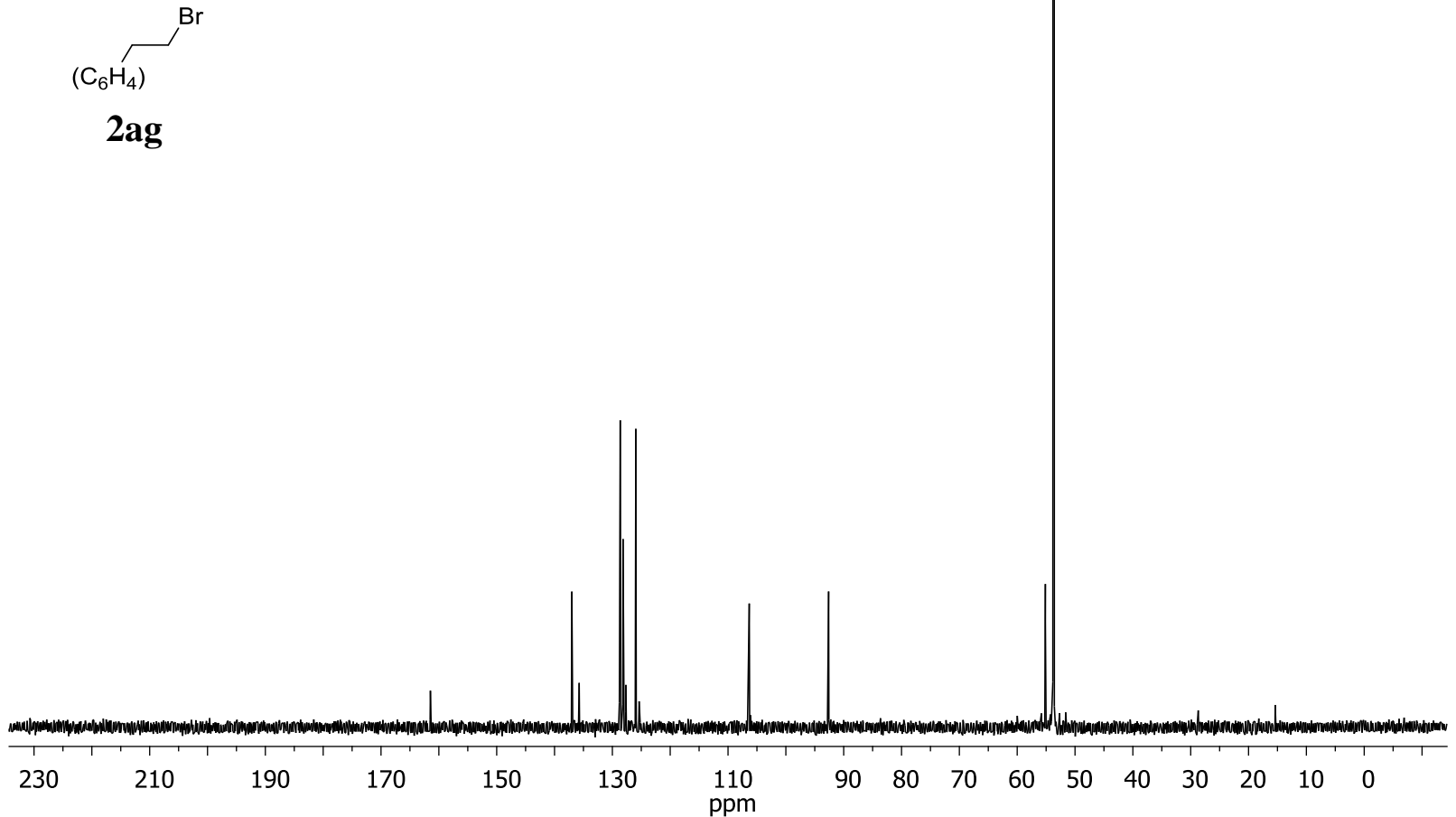


\section{C. ${ }^{1} \mathrm{H}$ and ${ }^{13} \mathrm{C}$ NMR Spectra of $4 \mathrm{a}-4 \mathrm{c}$}

phenylacetylene - PROTON $\mathrm{CDCl} 3$<smiles>CCPc1ccccc1</smiles>

$4 a$

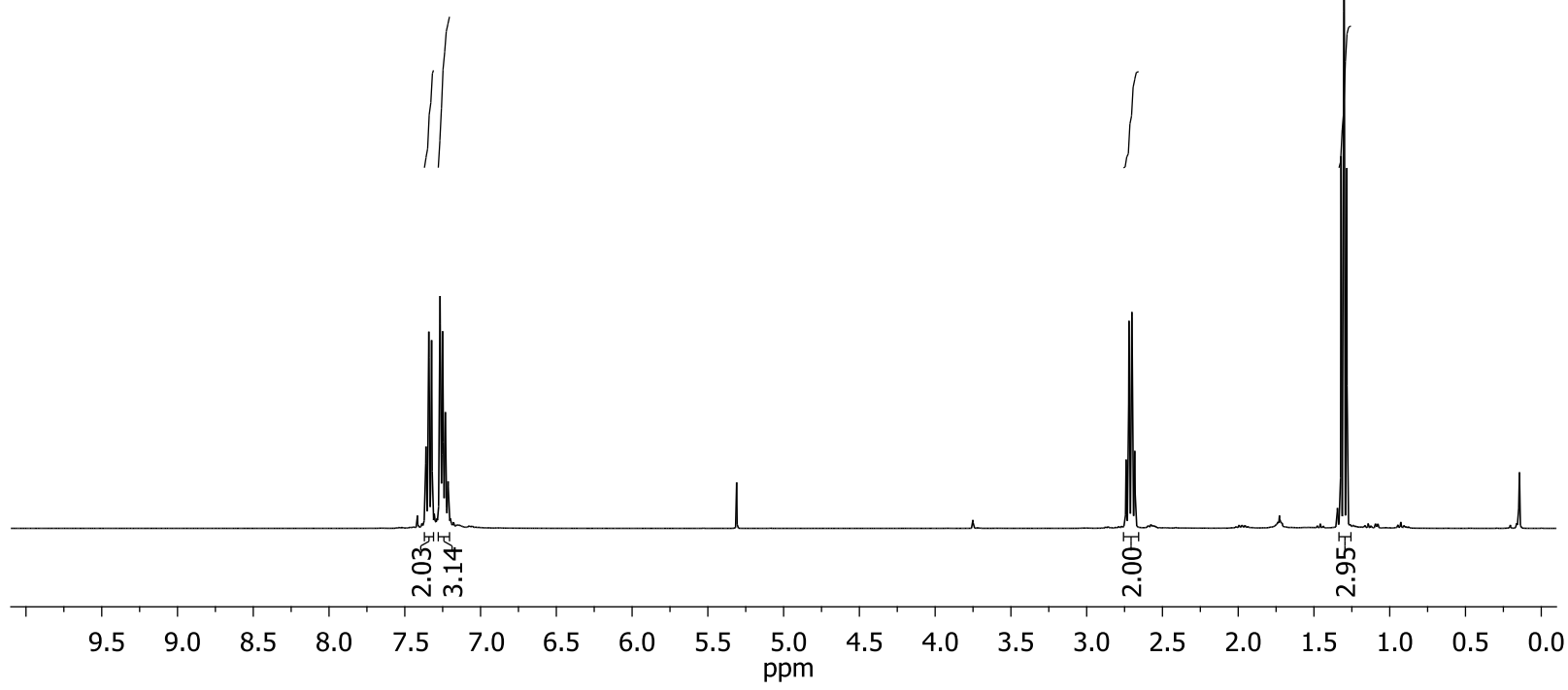

phenylacetylene - CARBON $\mathrm{CDCl} 3$<smiles>C1C[C@H]2CC[C@@H](C1)C2</smiles>

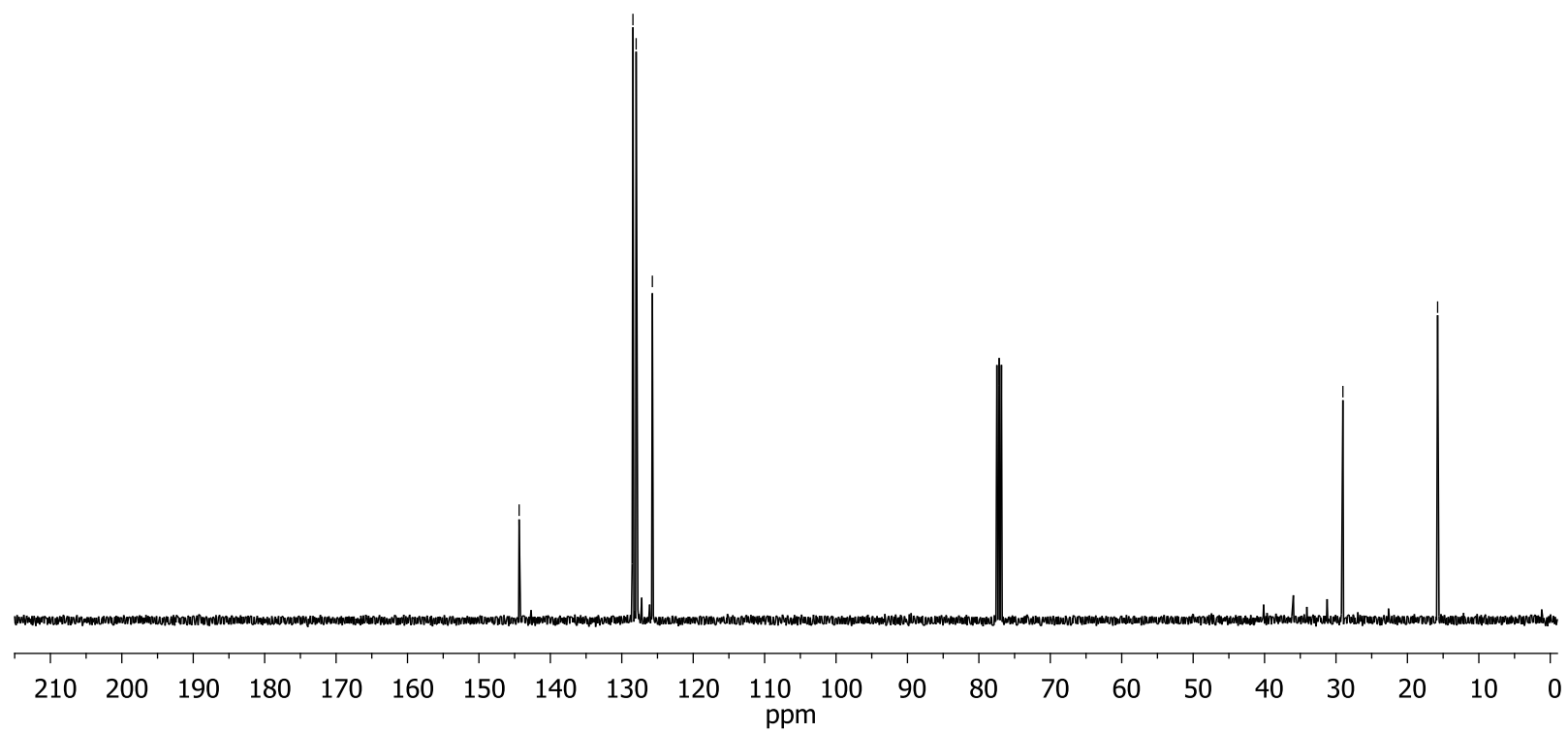


phenylpropyne - PROTON

$\mathrm{CDCl} 3$

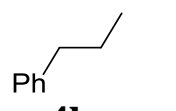

4b

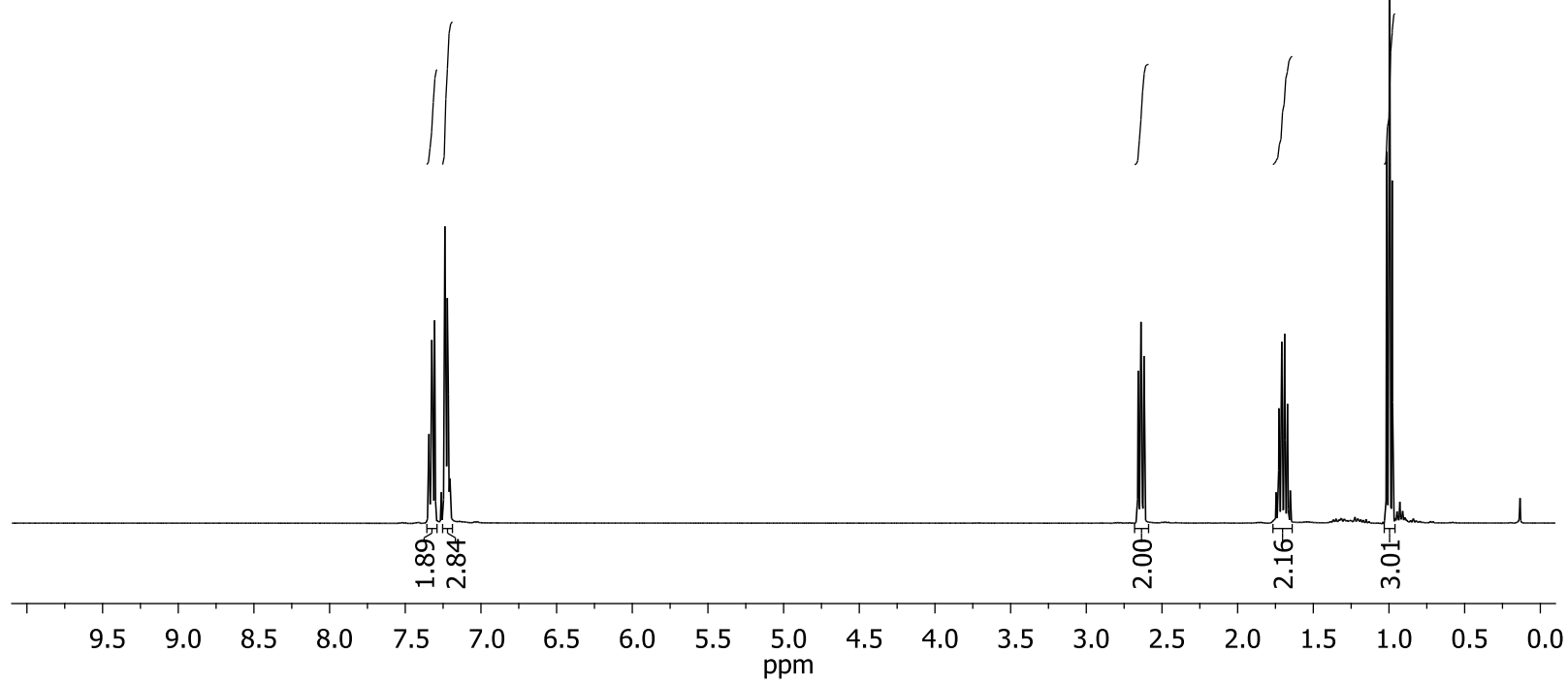

phenylpropyne - CARBON

$\mathrm{CDCl} 3$
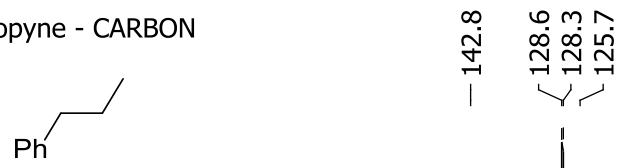

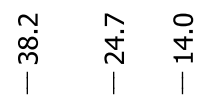

4b

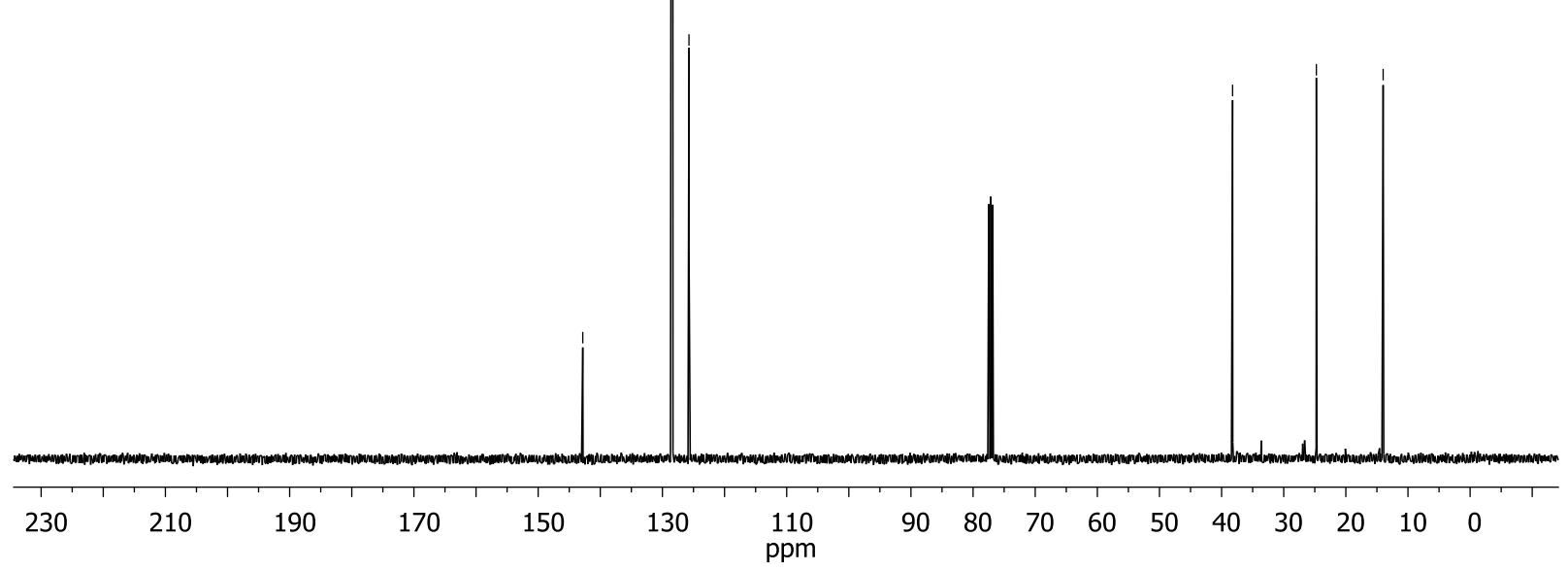


diphenylacetylene - PROTON

$\mathrm{CDCl} 3$
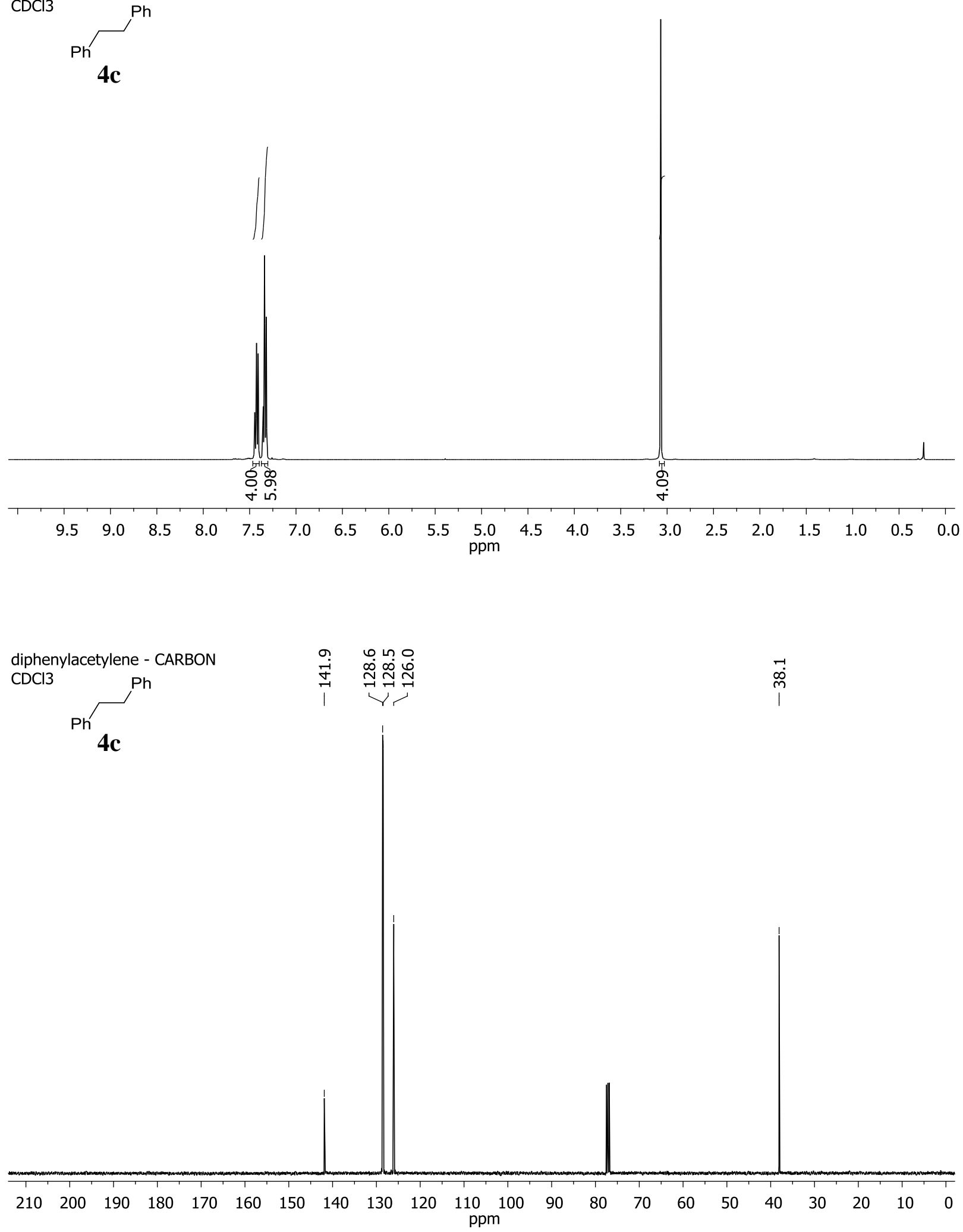
Diphenylacetylene - PROTON

Lindlars Catalyst at 35C

$\mathrm{CDCl} 3$

$$
{ }_{2 \mathrm{Ph}}{ }^{\mp} \mathrm{Ph}
$$
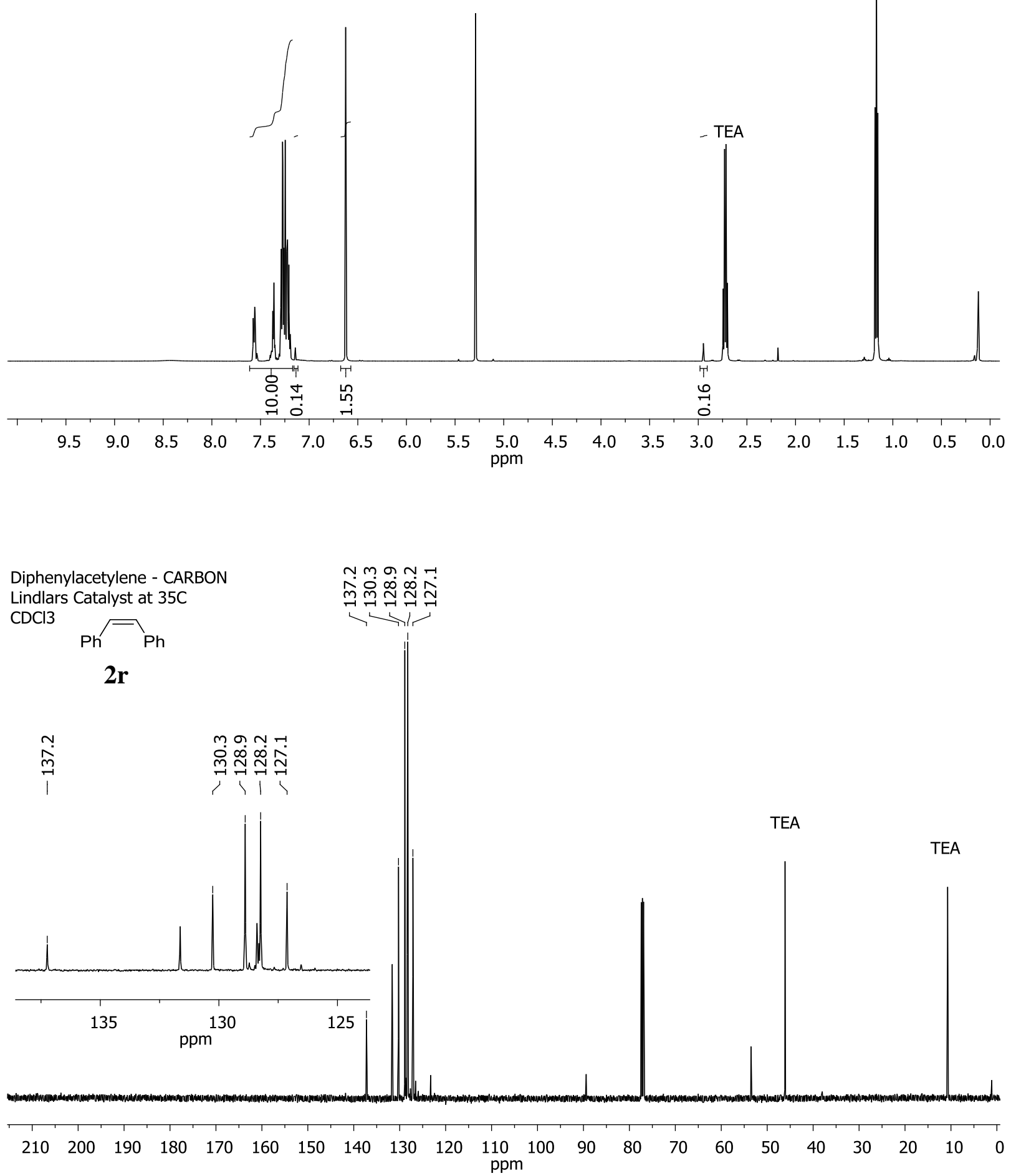


\section{D. ${ }^{1} \mathrm{H}$ and ${ }^{11}$ B NMR Spectra of phenethylboronic acid}

2-phenylethylboronic acid deprotection test - PRESAT $\mathrm{CH} 2 \mathrm{Cl} 2$
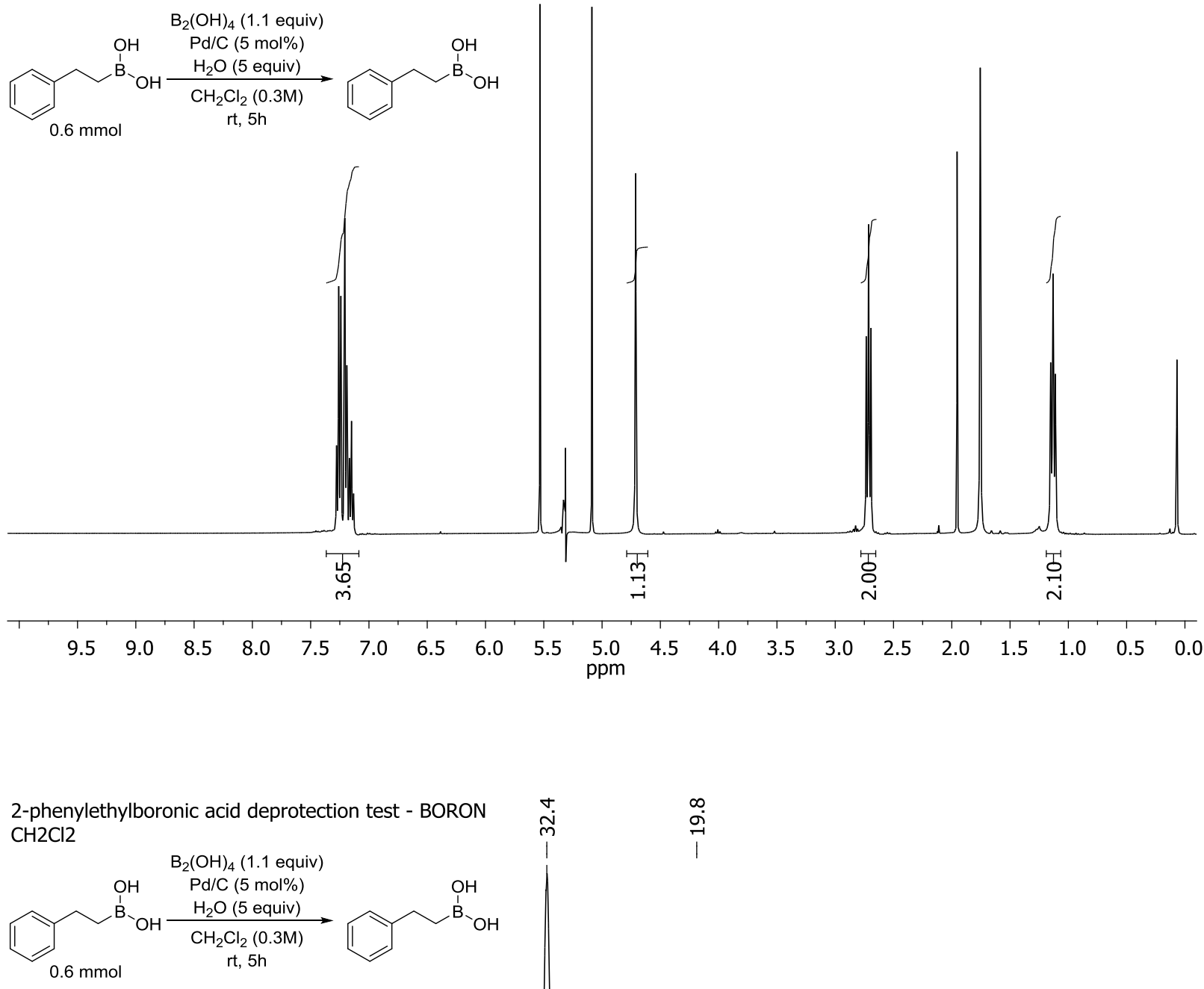

\begin{tabular}{|c|c|c|c|c|c|c|c|c|c|c|c|c|c|c|c|c|c|c|c|}
\hline 75 & 70 & 65 & 60 & 55 & 50 & 45 & 40 & 35 & & 25 & 20 & 15 & 10 & 5 & 0 & -5 & -10 & -15 & -20 \\
\hline
\end{tabular}




\section{E. ${ }^{1} \mathrm{H}$ and ${ }^{13} \mathrm{C}$ NMR Spectra of Deuteriation Reactions}

1,1-diphenylethylene by B2(OD)4 - PROTON

$\mathrm{CDCl} 3$

$\mathrm{Ph} \mathrm{H}(\mathrm{D})$

$Y \mathrm{CH}_{3}(\mathrm{D})$

2a

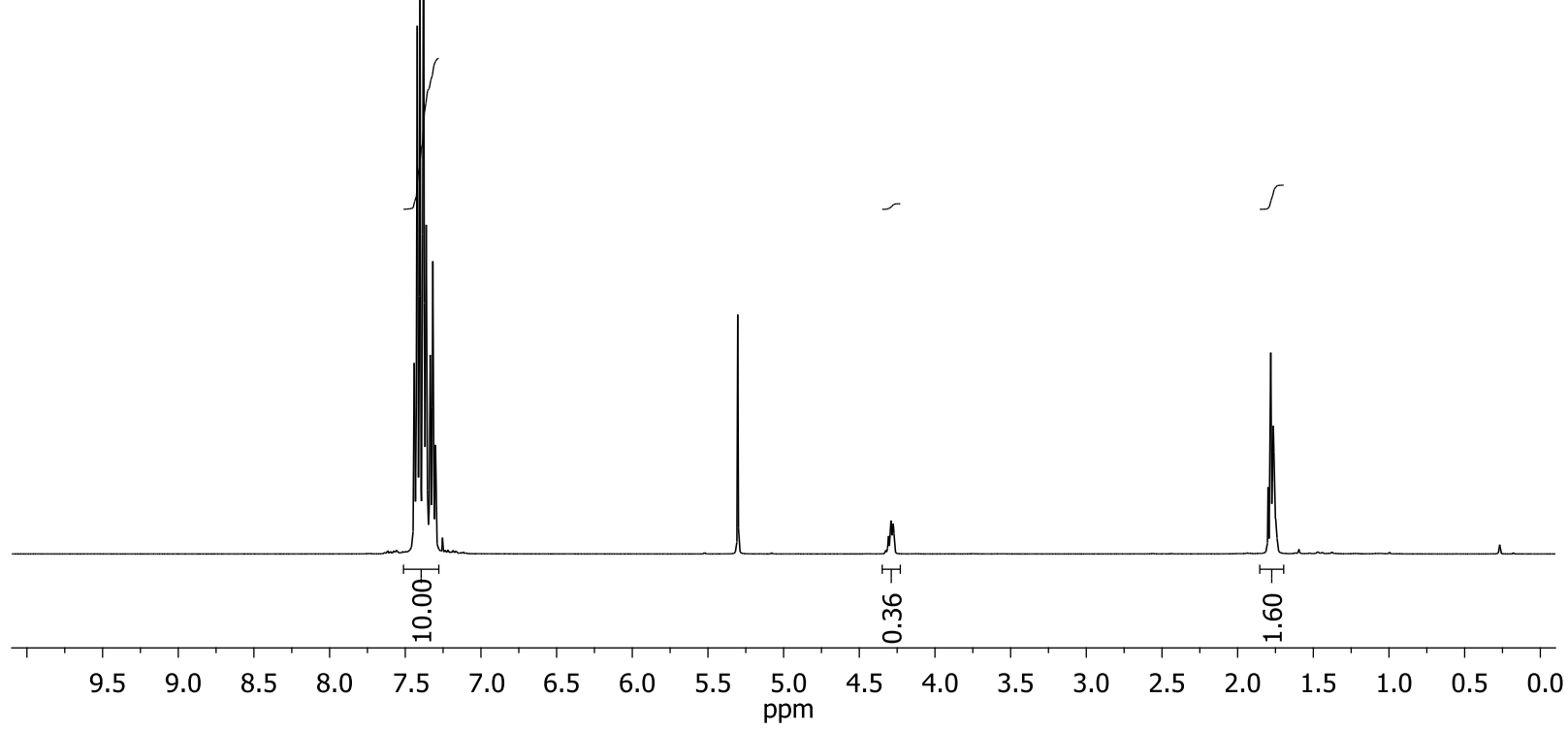

1,1-diphenylethylene by B2(OD)4 - CARB誌
CDCl3

2a

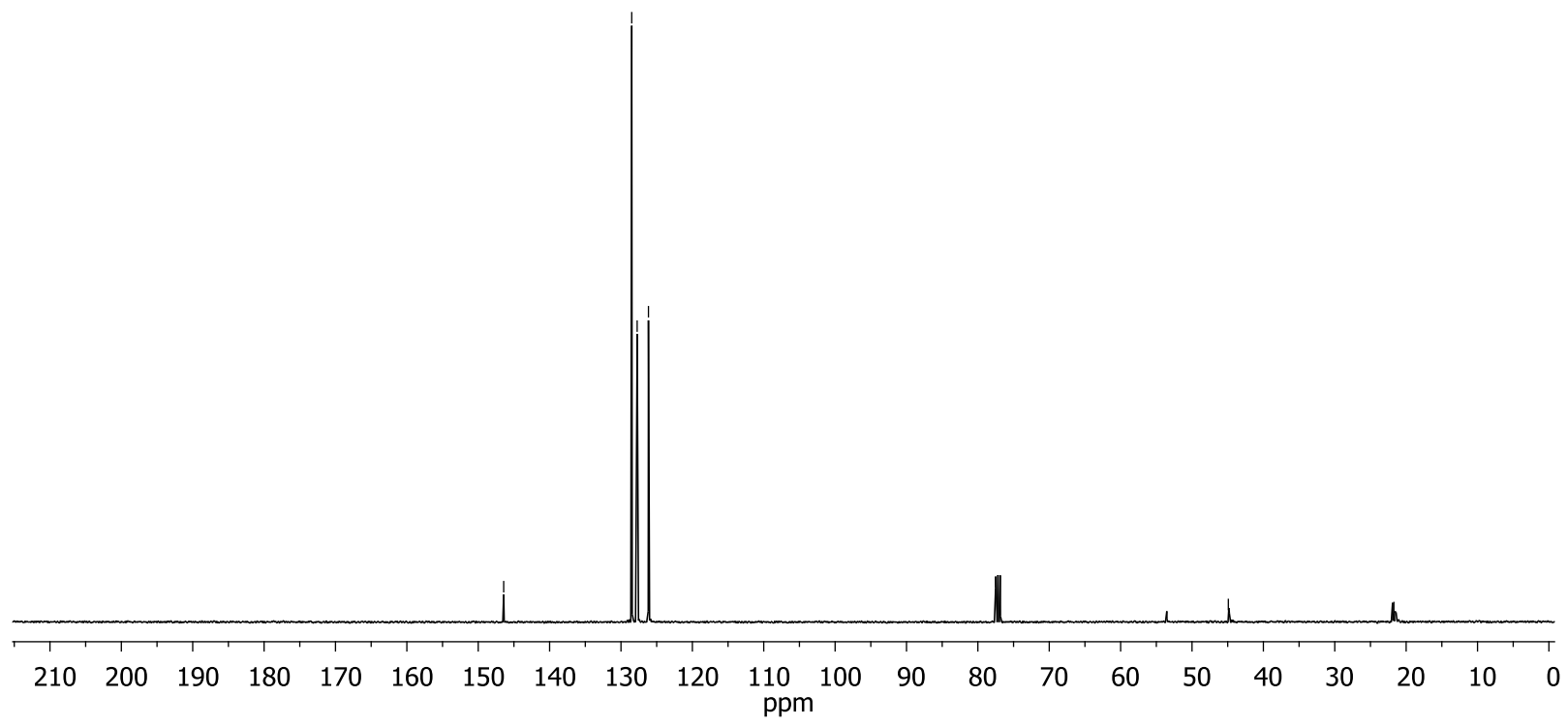


DPE Reduction via Pd - PROTON

B2(cat)2 in D2O

$\mathrm{CD} 2 \mathrm{Cl} 2$

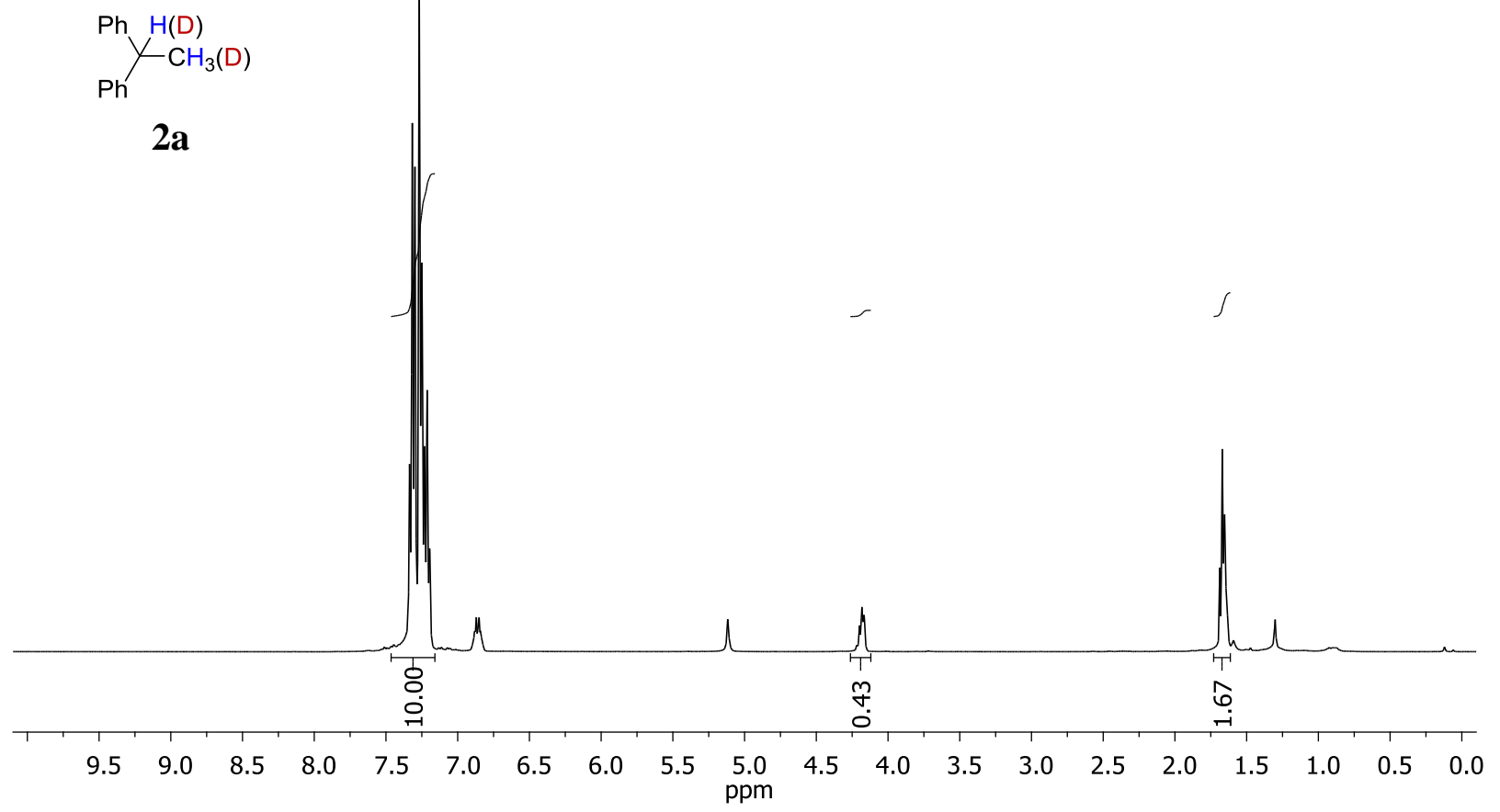

DPE deuteration via $\mathrm{Rh} / \mathrm{C}$

$\mathrm{CDCl} 3$

$\mathrm{Ph} \mathrm{H}(\mathrm{D})$

$\mathrm{Y} \mathrm{CH}_{3}(\mathrm{D})$

2a

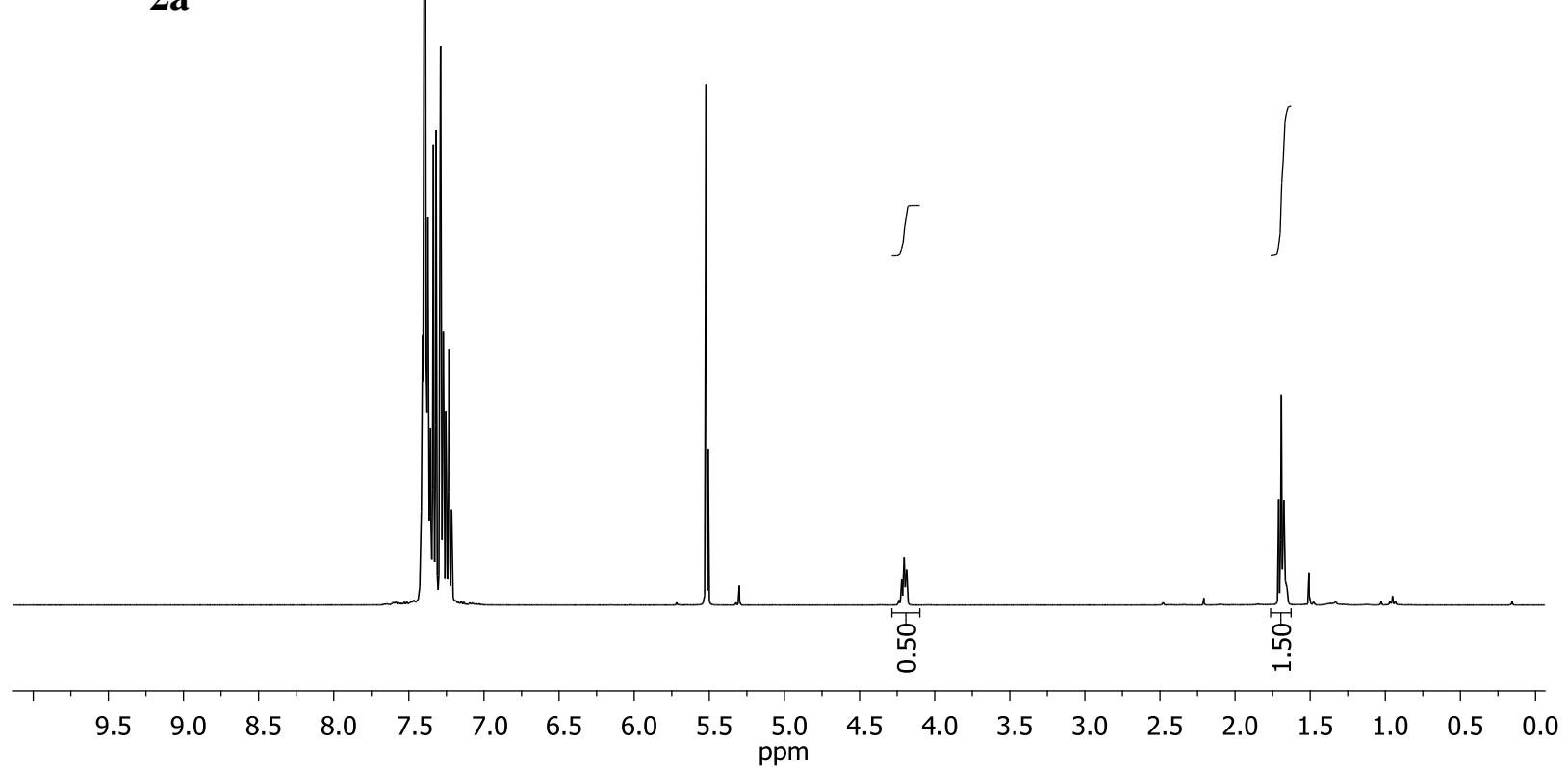


DPE deuteration via Pt/C

$\mathrm{CDCl} 3$

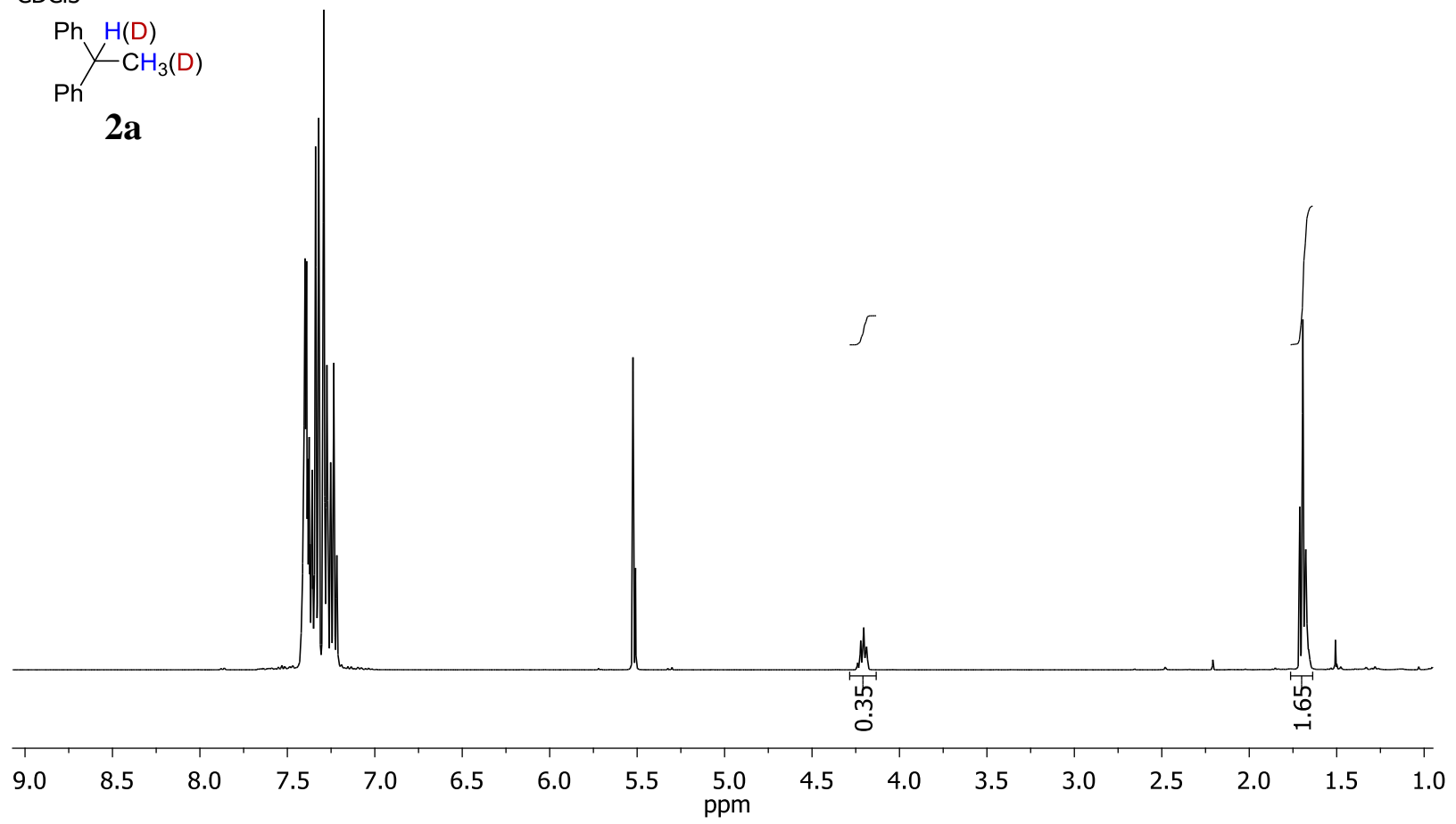

diphenylacetylene with $\mathrm{B} 2(\mathrm{OH}) 4$ - PROTON

10 second relaxation

$\mathrm{CH} 2 \mathrm{Cl} 2$

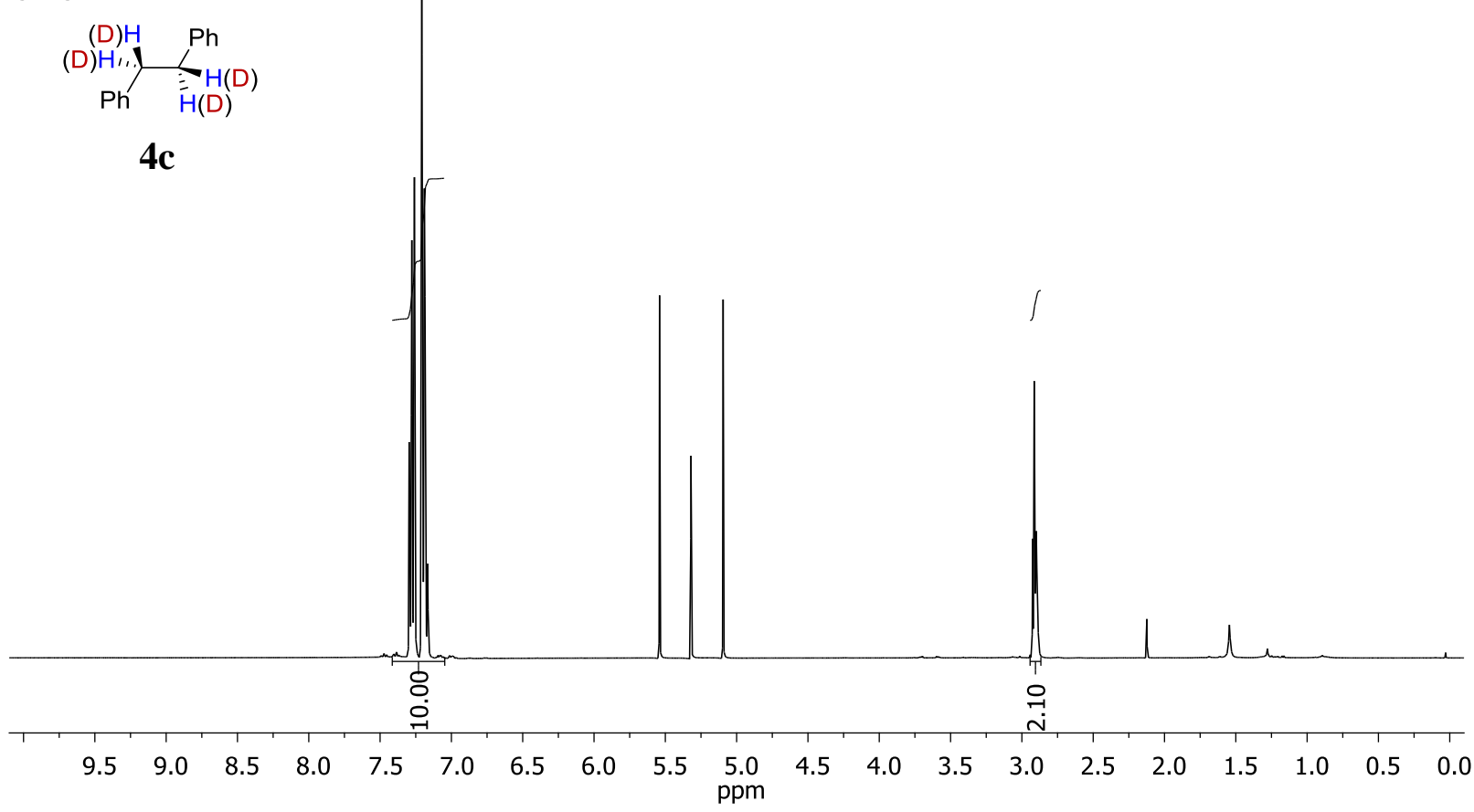


diphenylacetylene with $\mathrm{B} 2(\mathrm{OH}) 4$ and 50 equiv D2O - PROTON $\mathrm{CD} 2 \mathrm{Cl} 2$
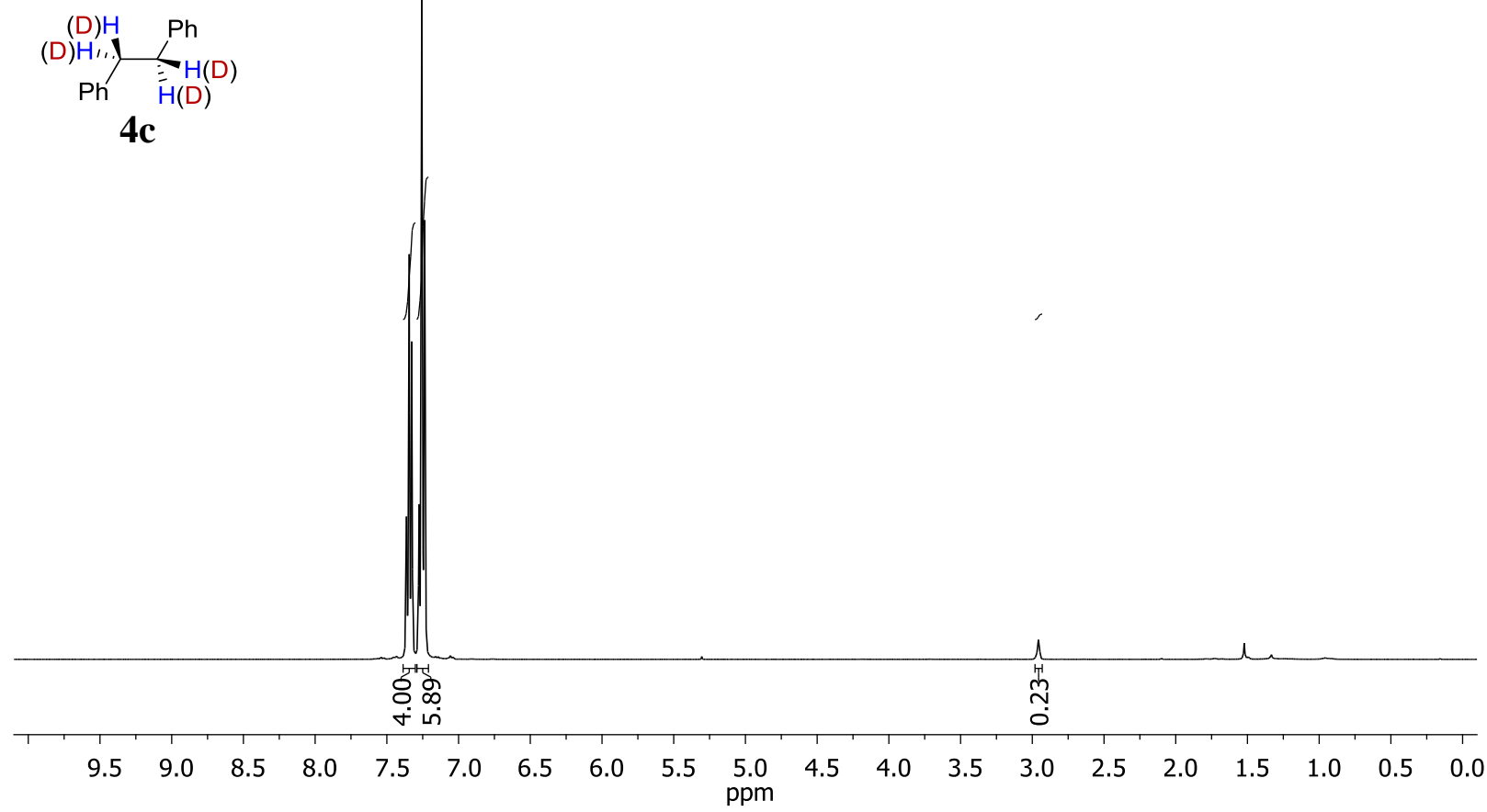

10212015 - Diphenylacetylene - D2O - PROTON B2(cat)2 with Pd $\mathrm{CD} 2 \mathrm{Cl} 2$ (D) $\mathrm{H}_{1}$

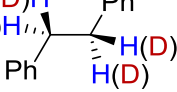
$4 c$

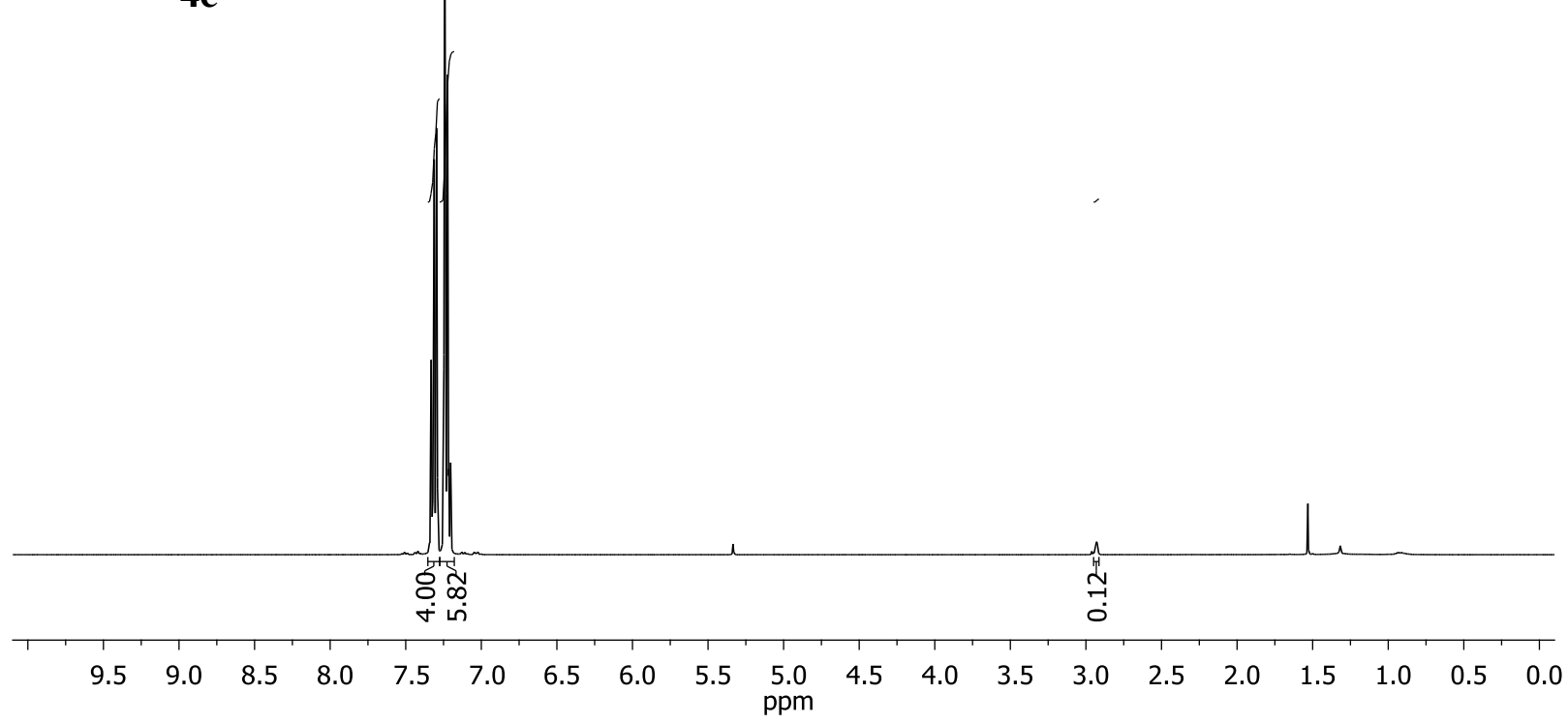




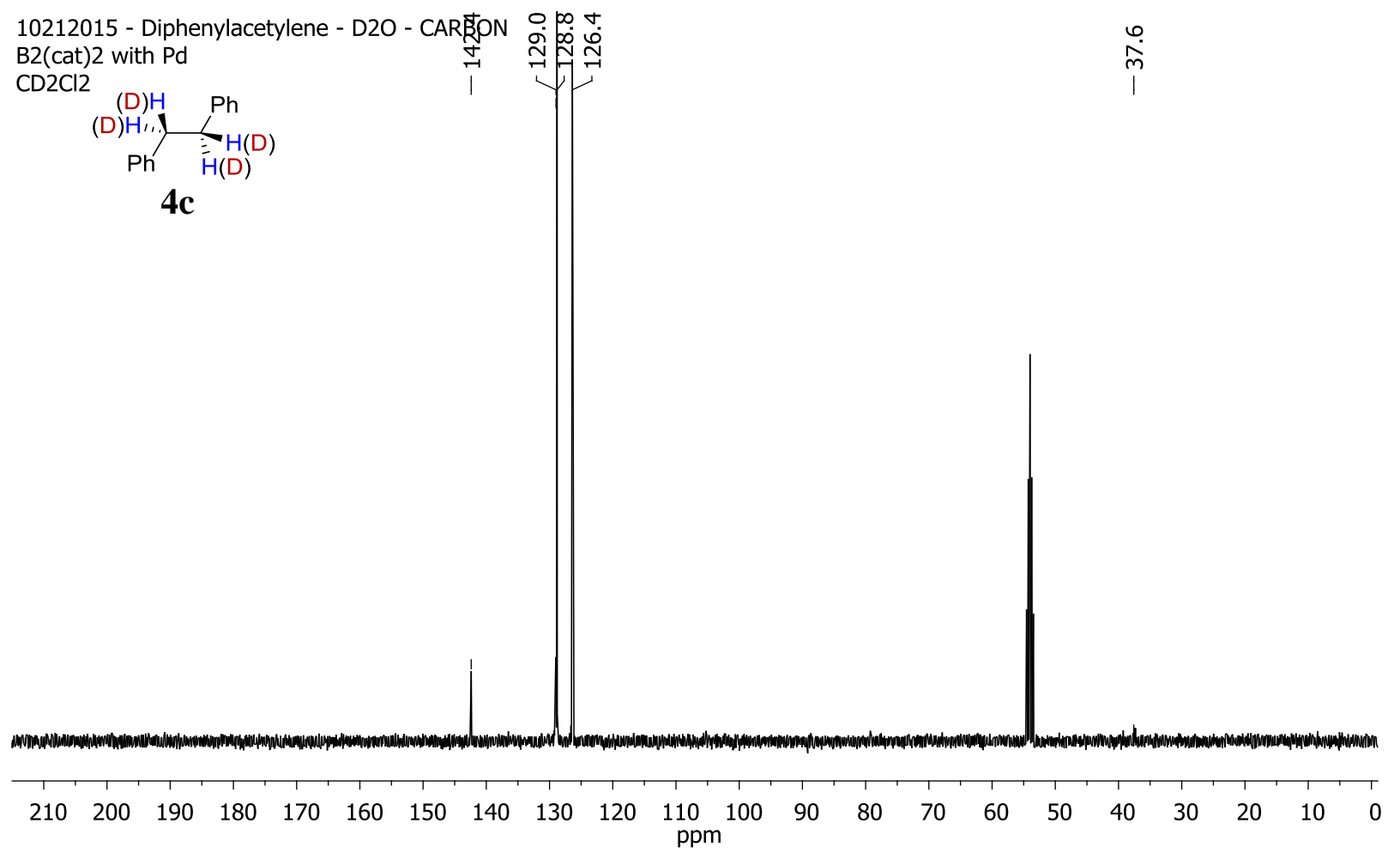

diphenylacetylene with B2(OD)4 - PROTON $\mathrm{CDCl} 3$

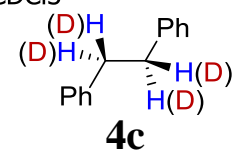

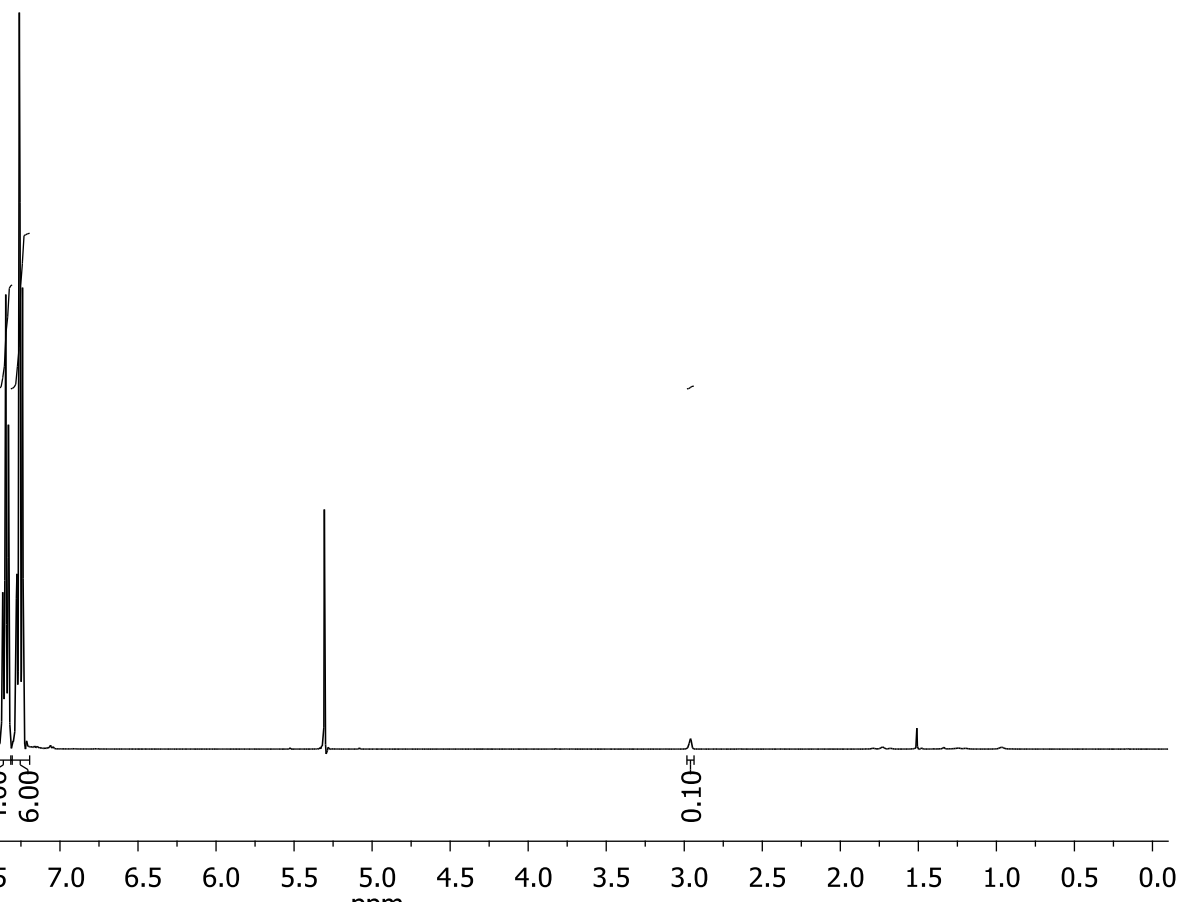


11132015 - diphenylacetylene - H2O:D2O - PROTON

8 second relax

$\mathrm{CD} 2 \mathrm{Cl} 2$
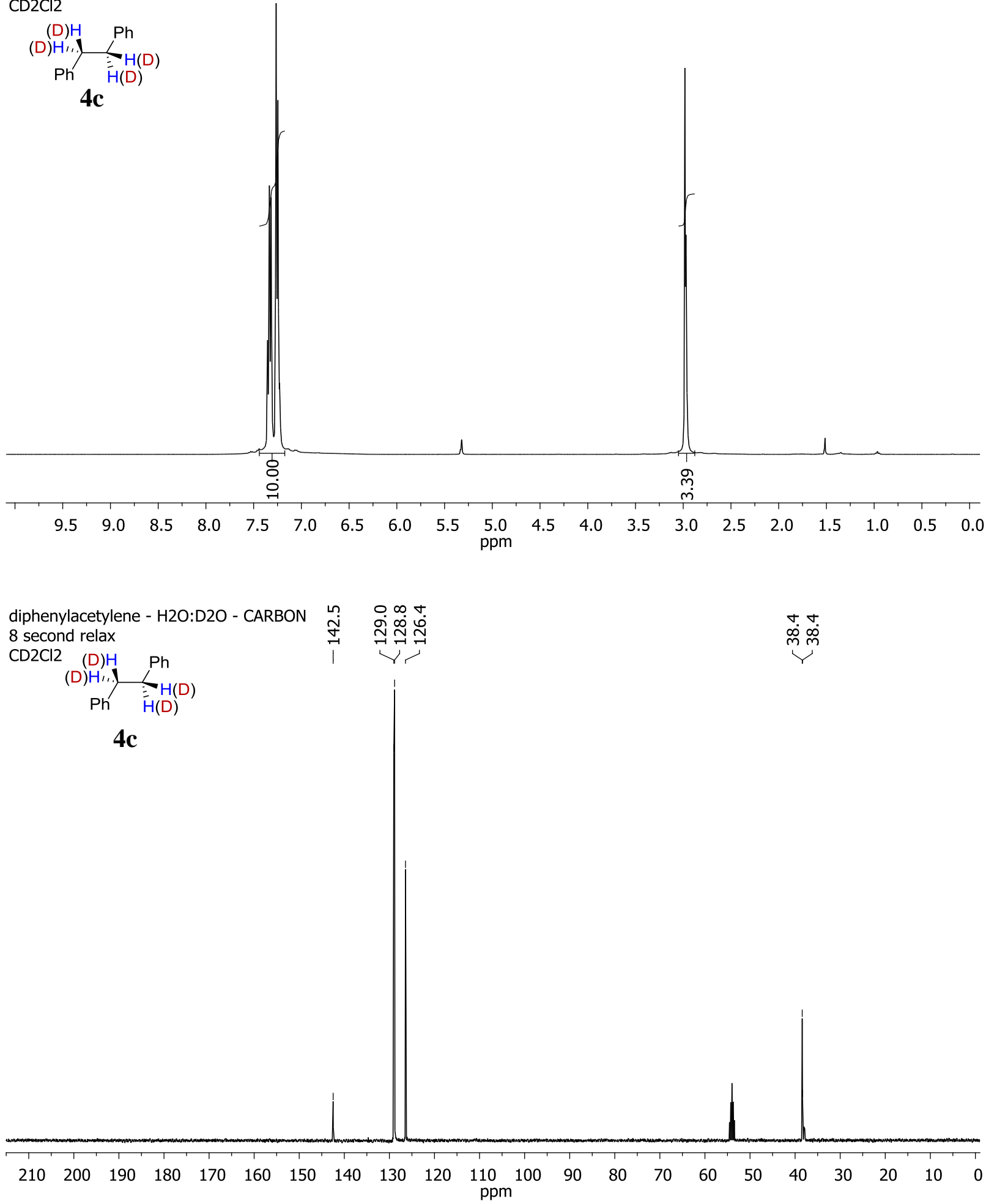


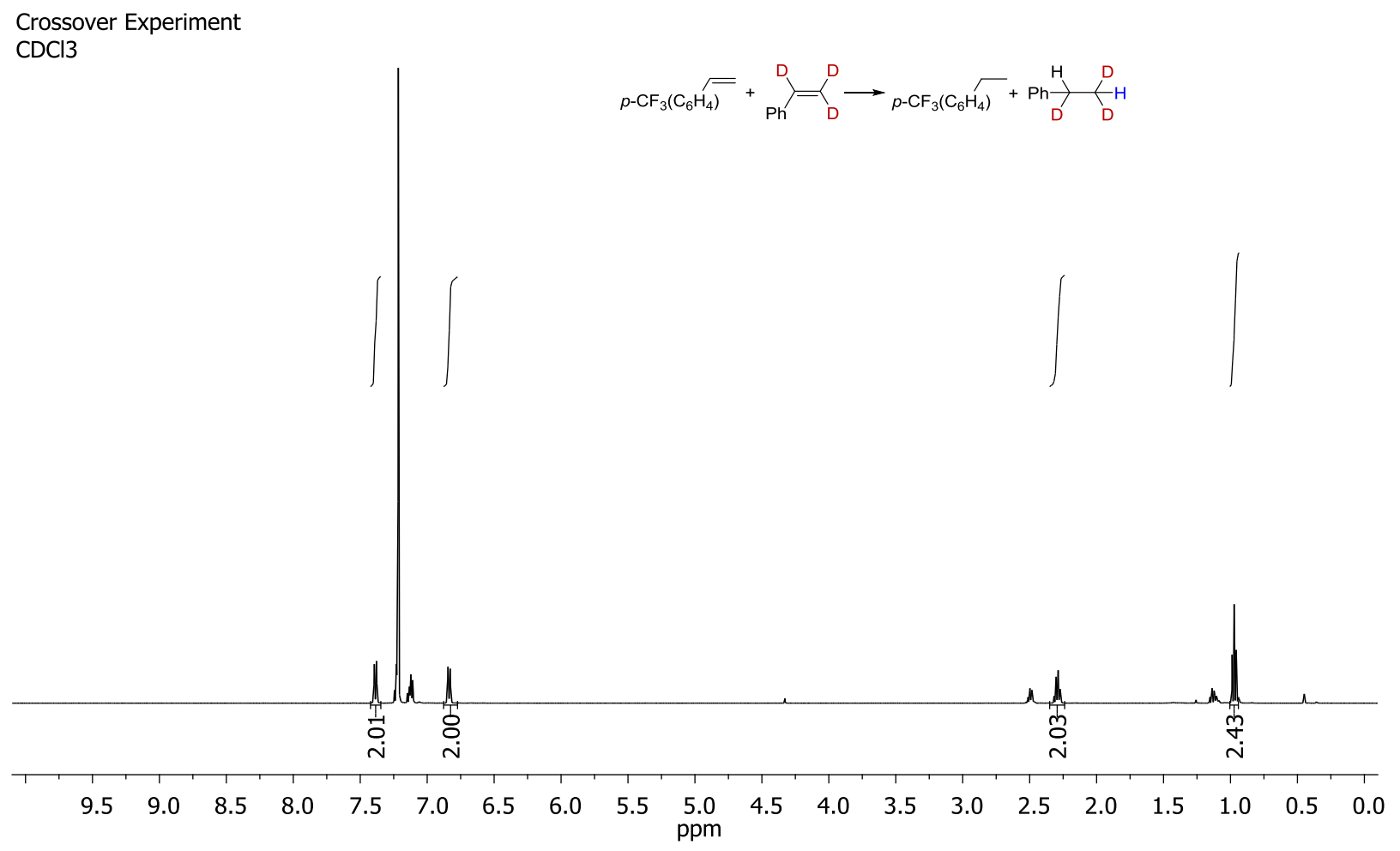

Norbornene Deuteration - PROTON

${ }_{\mathrm{CDCl} 3}^{\mathrm{B} 2(\mathrm{OD}) 4}$

2h

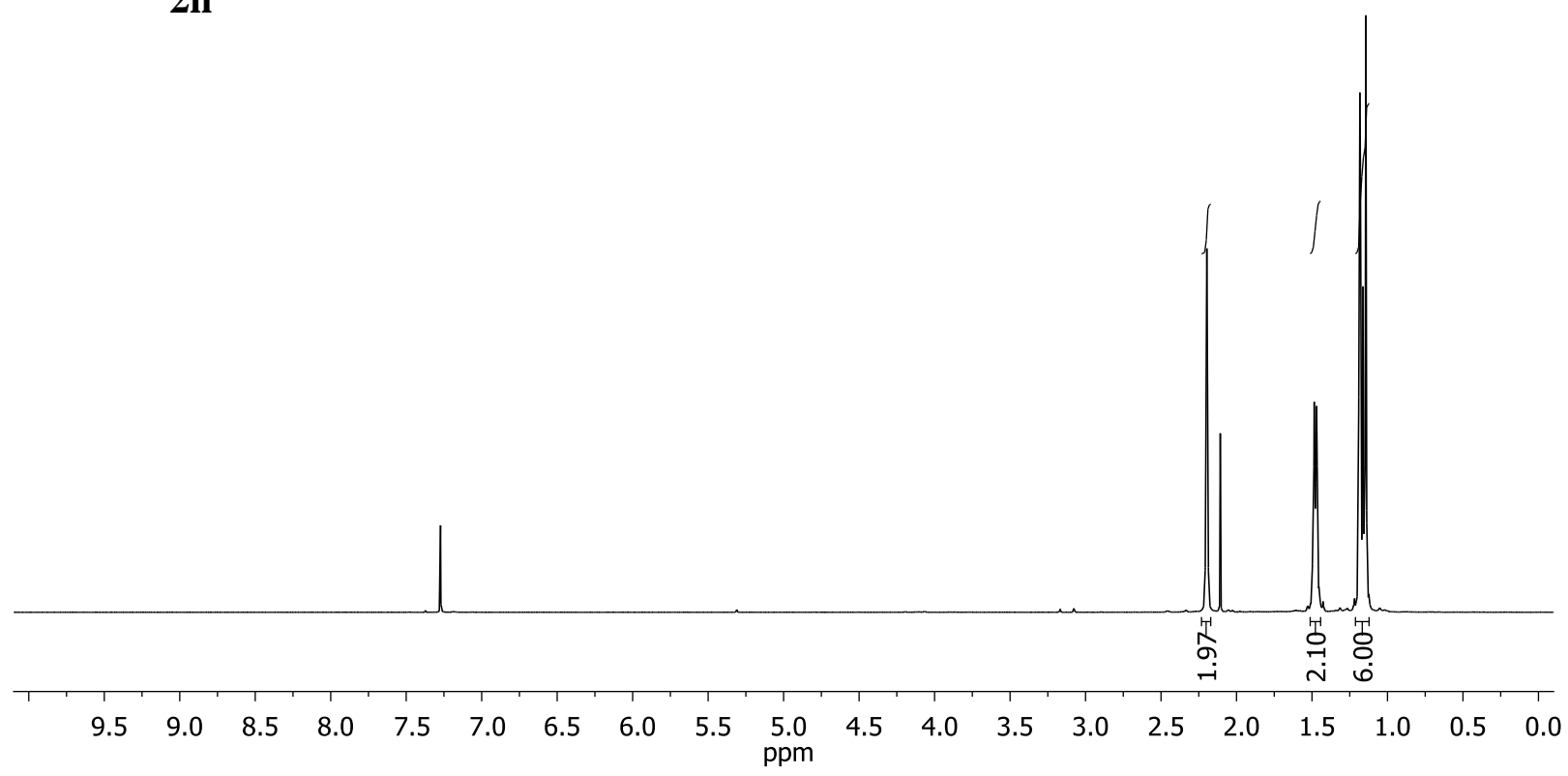


Norbornene Deuteration - CARBON

$\mathrm{B} 2(\mathrm{OD}) 4$

$\mathrm{CDCl} 3$<smiles>[2H]C1C2CCC(C2)C1O</smiles>

เก $\forall \infty$ เก t

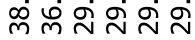

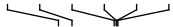

$2 h$

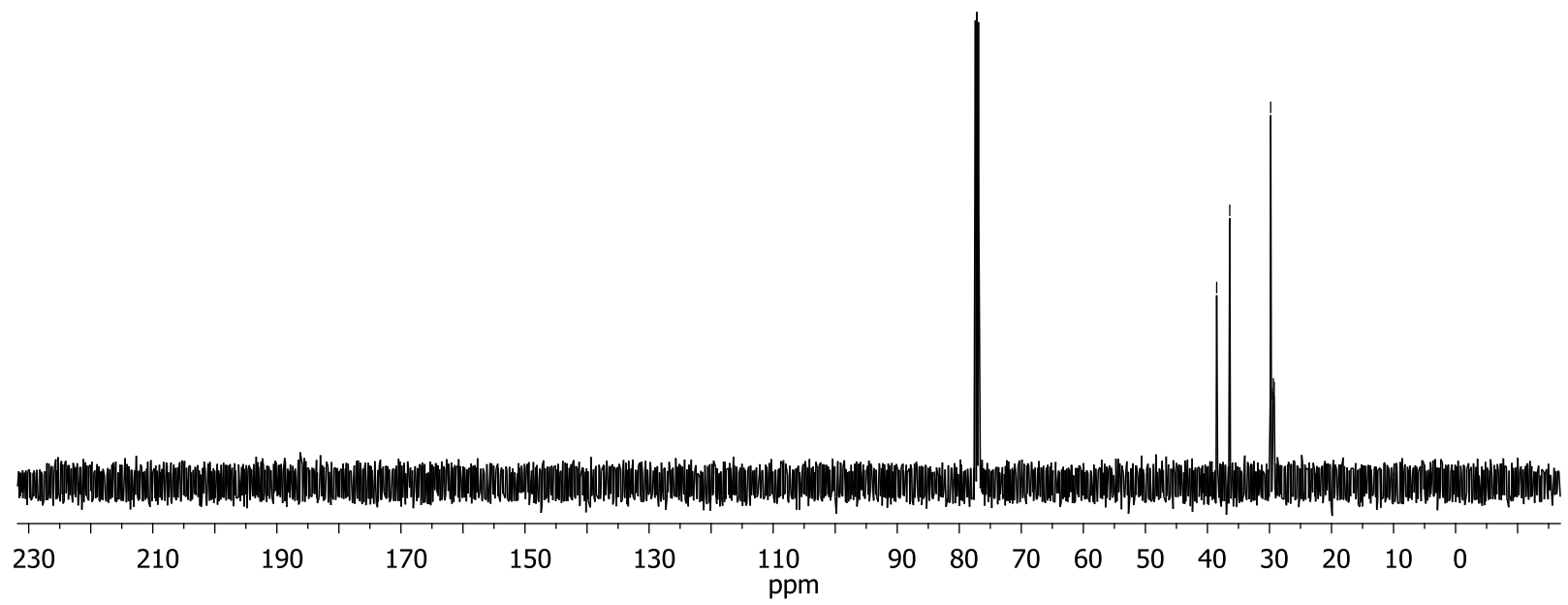

\section{F. ${ }^{1} \mathrm{H}$ NMR of $c$ is-stilbene mid-reaction}

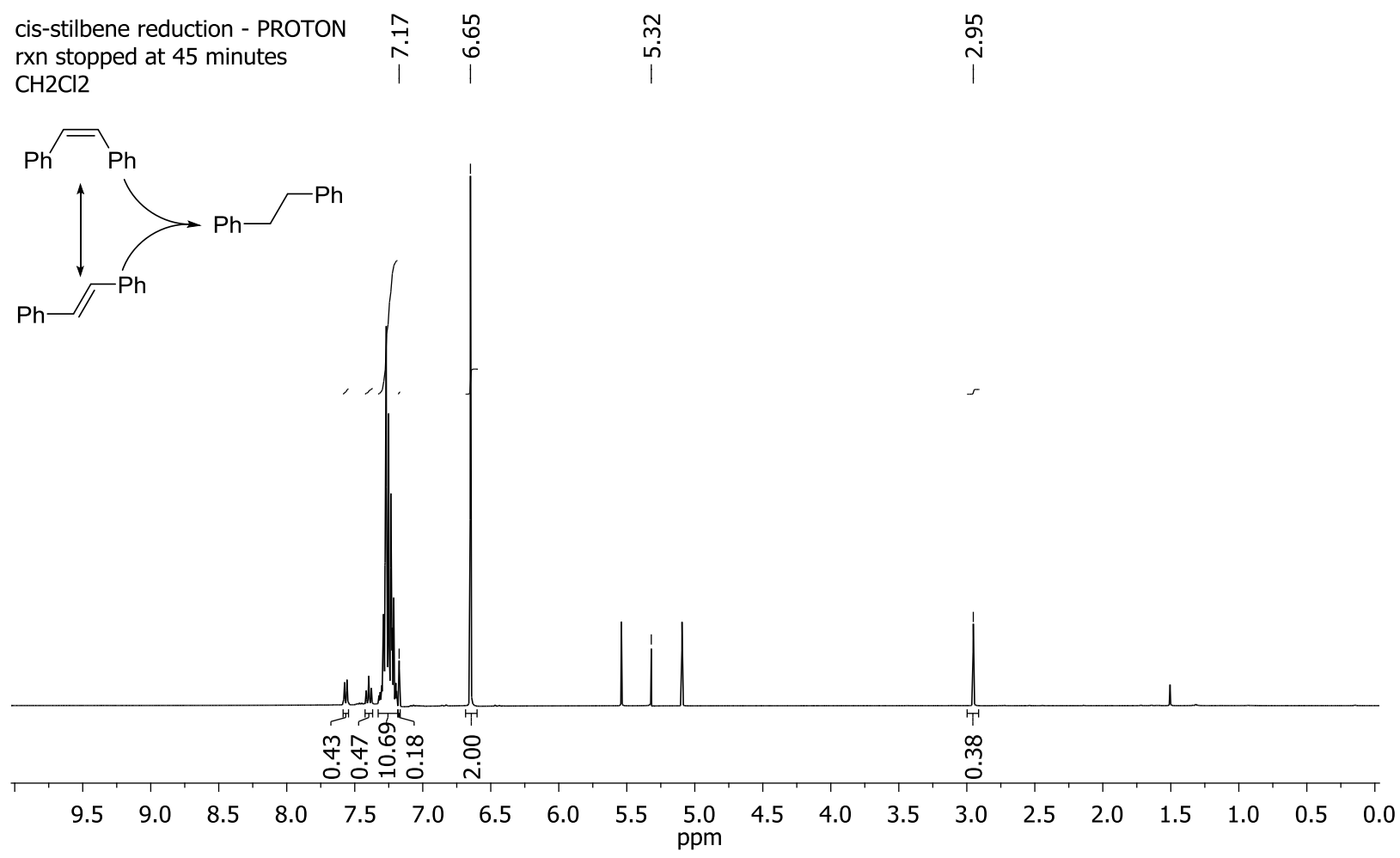

